\title{
APEX AND FUZZY MODEL ASSESSMENT OF ENVIRONMENTAL BENEFITS OF AGROFORESTRY BUFFERS FOR CLAYPAN SOILS
}

A Dissertation
presented to
The Faculty of the Graduate School
at the University of Missouri-Columbia
In Partial Fulfillment
of the Requirements for the Degree
Doctor of Philosophy
G. M. M. M. ANOMAA SENAVIRATNE
Ranjith P. Udawatta and Stephen H. Anderson,
Dissertation Supervisors

MAY 2013 
(C) Copyright by G.M.M.M. Anomaa Senaviratne 2013

All Rights Reserved 
The undersigned, appointed by the Dean of the Graduate School, have examined the dissertation entitled

\section{APEX AND FUZZY MODEL ASSESSMENT OF ENVIRONMENTAL BENEFITS OF AGROFORESTRY BUFFERS IN CLAYPAN SOILS}

presented by

\section{G.M.M.M. ANOMAA SENAVIRATNE}

a candidate for the degree of

\section{DOCTOR OF PHILOSPHY}

and hereby certify that, in their opinion, it is worth of acceptance.

Professor Ranjith P. Udawatta (Chair)

Professor Stephen H. Anderson (Co-Chair)

Professor Claire Baffaut

Professor Allen L. Thompson 
TO MY LATE PARENTS, FAMILY AND FRIENDS 


\section{ACKNOWLEDGEMENTS}

I would never have been able to finish my dissertation without the guidance of my committee members, help from friends and support from my family members.

First and foremost, my utmost gratitude goes to my advisor, Dr. Ranjith P. Udawatta, for awarding the assistantship for my research study and generously sharing his hard earned research data without which this dissertation would not have been a realization. I am also grateful for his dedicated guidance and support provided for this project to make it a completion. I cannot find words to thank him for constantly pushing and persuading me for an early start for publication and presentation of the research and also making me participate in many conferences and training workshops. His strong reviews and criticisms made my writing stronger and I am very much thankful for his patient and prompt corrections of my written work. I also wish to thank him for withstanding all the tough times I underwent in both professional and personal life.

It is with deep pleasure I acknowledge the support and help of my co-adviser, Dr. Stephen H. Anderson had it not been for his constant monitoring and keeping me up to date on both of my course work and research requirements, the completion of this project would have possible. He gave his best suggestions whenever I was faced with dilemmas in both course work and research work and his long experience with students as a professor was an asset to me in getting the correct advice.

I wish to express my deep appreciation to Dr. Claire Baffaut as this dissertation 
would not have been possible without her support as well. Her strong criticisms and reviews based on her knowledge and experience in hydrologic modeling immensely helped me to improve and sharpen both my research work and writings. Her interest in my work made her surpass as the capacity of a committee member in her contributions to this project.

I also wish to sincerely thank Dr. Allen L. Thompson for agreeing to be my external committee member and also for all the support given to me in time and advice during the examinations, research work and publications. I am also grateful for the assistance provided to me by Dr. Verel Benson to help me out from the initial obstacles I faced in learning the model. My great appreciation goes to my friend Nakini Thushar Kanta Das for his invaluable help in MATLAB programming offered generously by spending his most invaluable time and energy.

I take this opportunity to sincerely thank the Center for Agroforestry and the University of Missouri for providing the financial assistance for my program. Also I take this opportunity to acknowledge the departmental staff of Soils, Environmental, and Atmospheric Science, including the Chair, Dr. Tony Lupo, the graduate director, Dr. Peter Motavalli and Ms. Karen Decker for the assistance offered to me directly or indirectly. Also I wish to thank the International Center for their kind assistance and the University Health Center and the Hospital for looking after me during the two surgeries I had to undergo and other sicknesses.

Also my sincere appreciation and gratitude goes to my friends, Mihiri, Sriyan, and 
Romayne in helping me out at difficult times. My warm appreciation goes to my cousin Nelum for being my sister supporting me in every way possible to make my life bearable during my stay here. I thank my colleagues Kerry, Fausty, Langston, Bei, Cammy, Kate, Piyush, Leyla and Tae for their team work during the study times and also for their friendship and encouragement.

Last but not least my deep gratitude and appreciation goes to my husband Mr. Kapila Munasinghe and my two sons Indeewara and Chavinda for releasing me to pursue this very demanding program and giving me moral support and encouragement. My utmost gratitude goes to my late parents for upbringing me to the person I have become.

Place: Columbia, MO

Date: May $3^{\text {rd }} 2013$

Anomaa Senaviratne 


\section{TABLE OF CONTENTS}

ACKNOWLEDGEMENTS ...................................................................................... ii

LIST OF TABLES ............................................................................................... ix

LIST OF FIGURES.............................................................................................

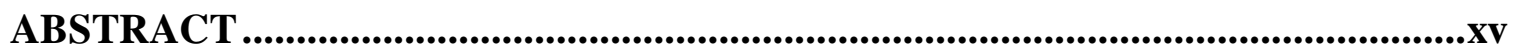

CHAPTER 1

INTRODUCTION ....................................................................................................1

\section{CHAPTER 2}

LITERATURE REVIEW ...............................................................................12

Soil Erosion and Non-Point Source Pollution (NPSP) .................................... 12

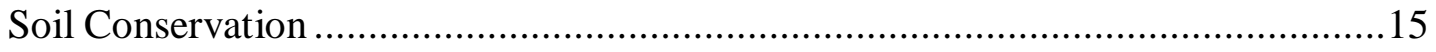

Agroforestry Practices and Conservation Buffers.......................................... 18

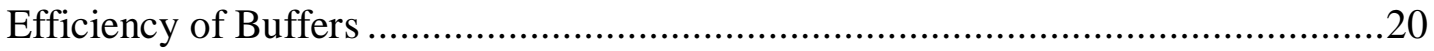

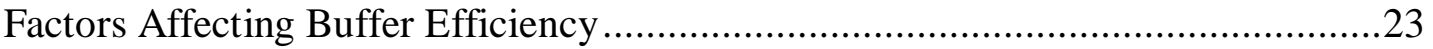

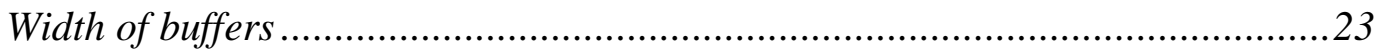

Slope, slope length, soil texture, and soil structure ........................................24

Pollutant type ...........................................................................................2 26

Ratio of buffer area to source area ...........................................................2 27

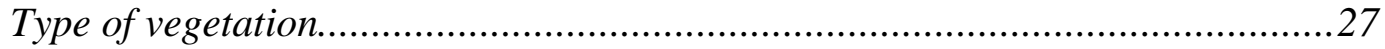

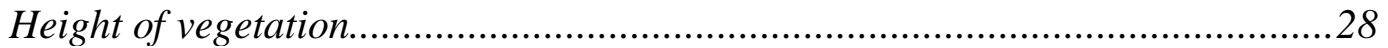

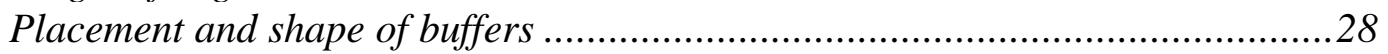

Problems encountered with buffers .............................................................29

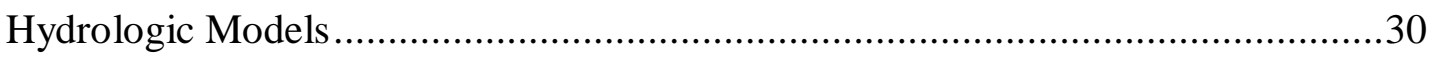

Agricultural Policy Environmental eXtender (APEX) Model ...............................33

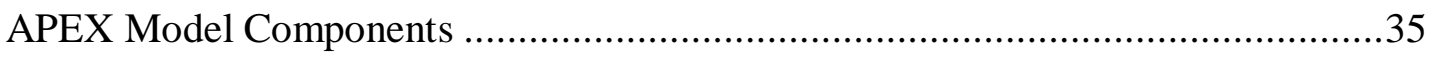

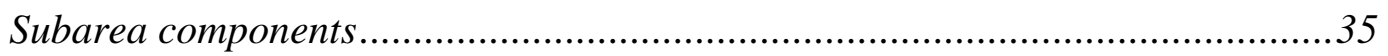

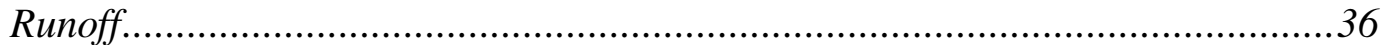

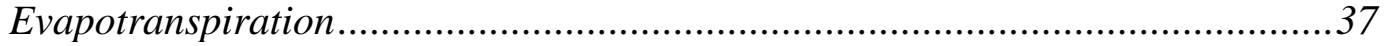

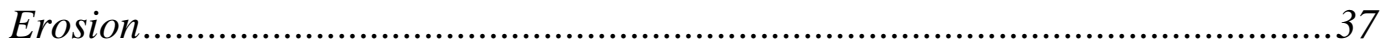

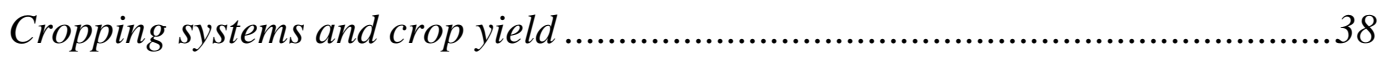

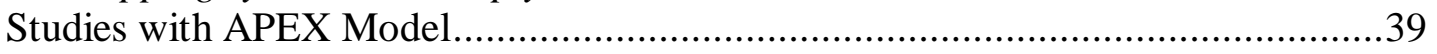

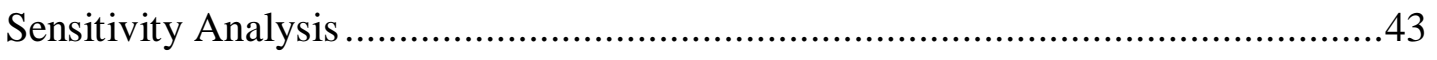

Global Optimization Methods for Parameter Calibration .....................................44

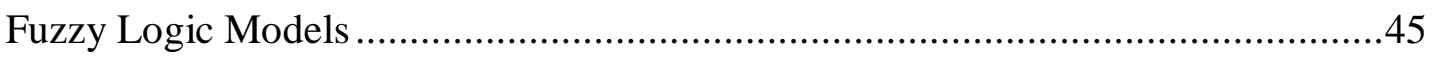




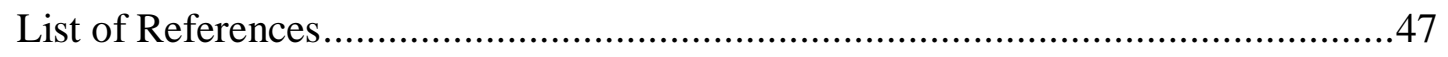

\section{CHAPTER 3}

APEX simulation of three adjacent row-crop watersheds in the claypan region......62

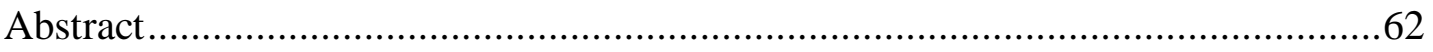

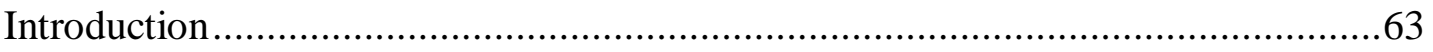

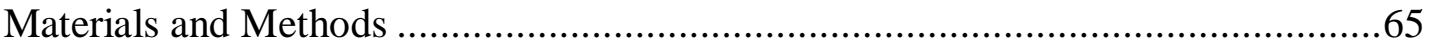

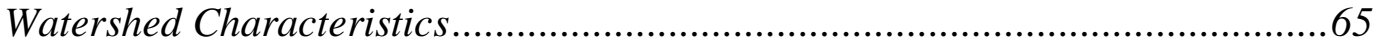

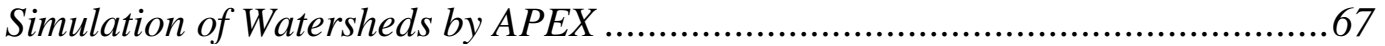

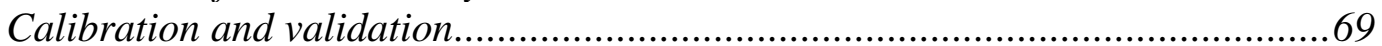

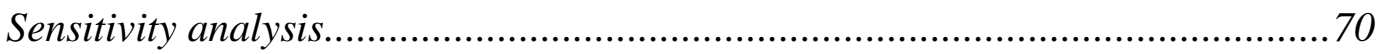

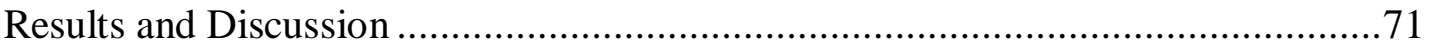

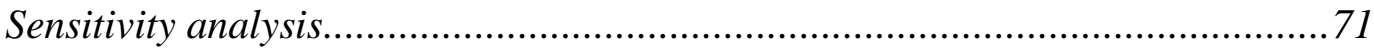

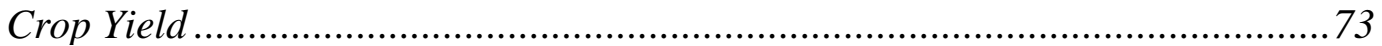

Runoff, Sediment, TN and TP Losses.........................................................

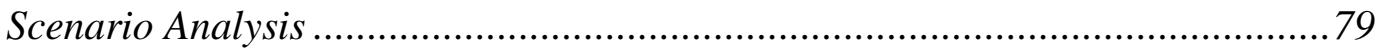

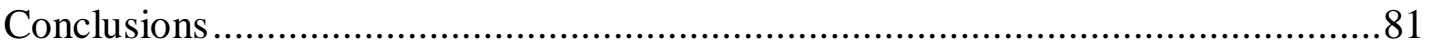

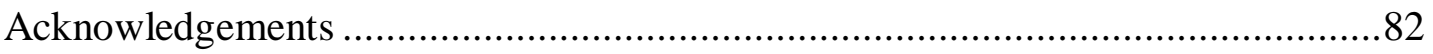

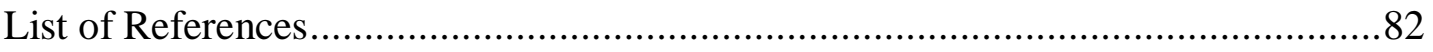

\section{CHAPTER 4}

APEX simulation: environmental benefits of agroforestry and grass

buffers FOR corn-soybean watersheds ............................................................................98

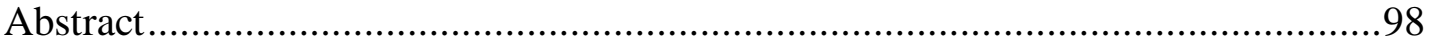

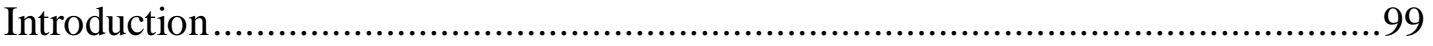

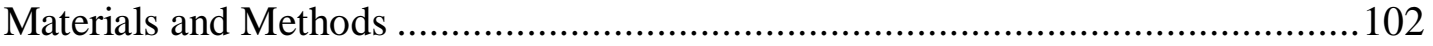

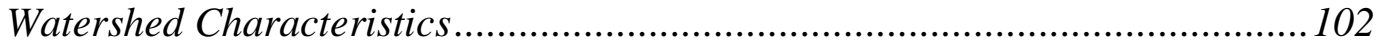

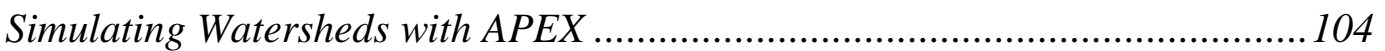

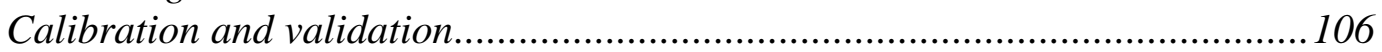

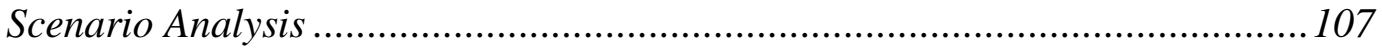

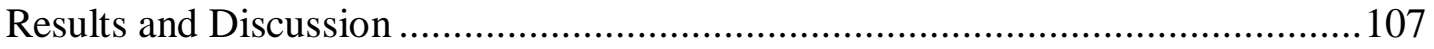

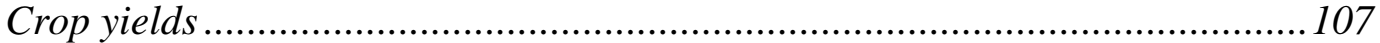

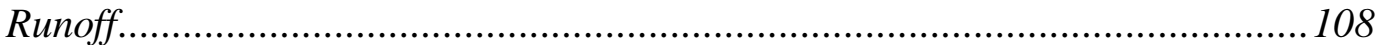

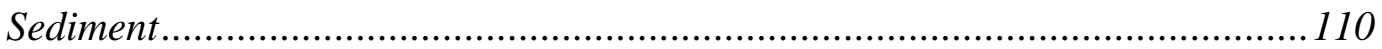

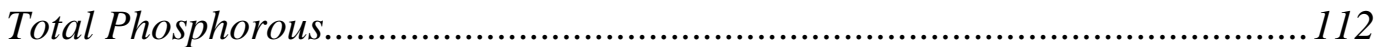

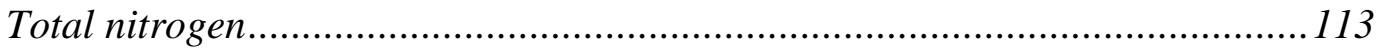

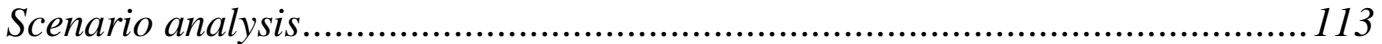

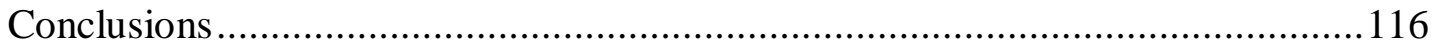

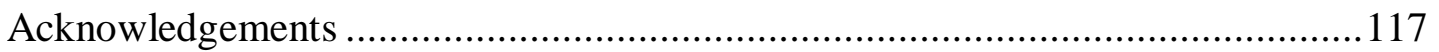

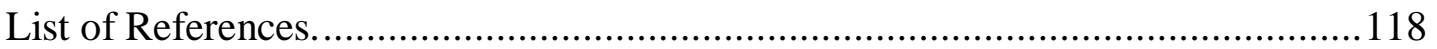




\section{CHAPTER 5}

\section{Performance of Geno-Fuzzy Model on Rainfall-Runoff Predictions}

in Claypan Watersheds

Abstract

Introduction....

Study watersheds.

Fuzzy Logic Model Development

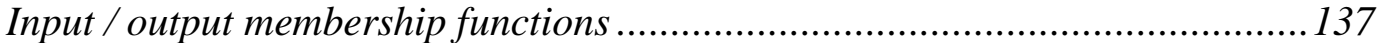

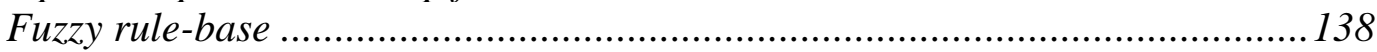

Fuzzy inference engine ...................................................................... 140

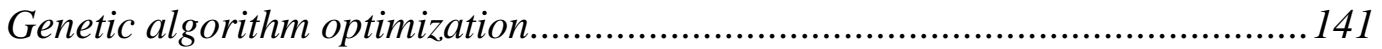

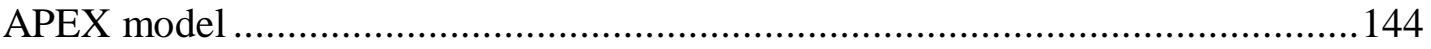

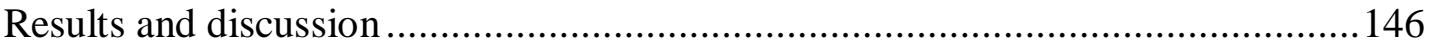

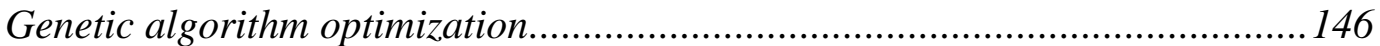

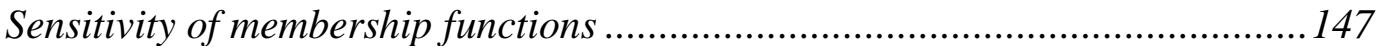

Varying the number of years and events used for calibration ......................... 147

Fuzzy inference system simulations compared to APEX model predictions for pre- and post-buffer watersheds at Greenley

Memorial Research Center......................................................................... 148

Fuzzy inference system simulation of larger Long Branch watersheds ............ 150

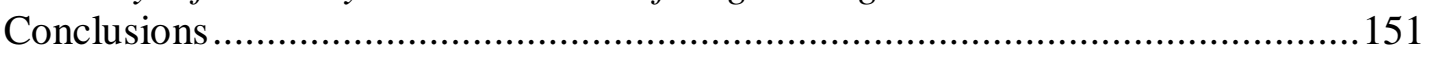

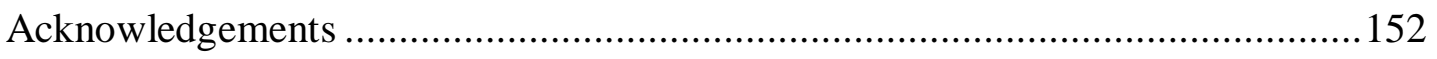

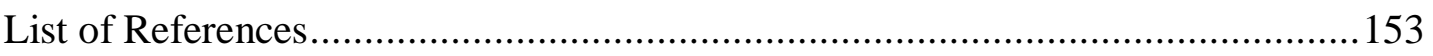

\section{CHAPTER 6}

Multi-variable, multi-objective stepwise parameter optimization

for Agricultural Environmental Policy eXtender model...........................................170

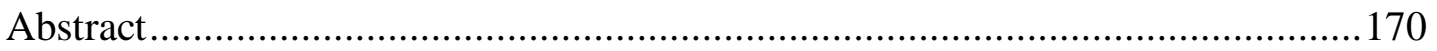

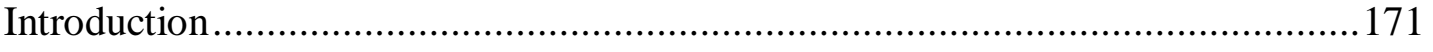

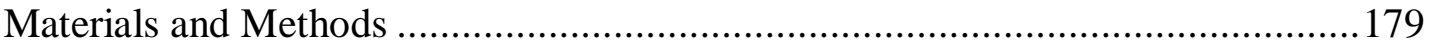

The study watersheds and APEX model simulations................................... 179

Global parameter optimization and calibration ......................................... 180

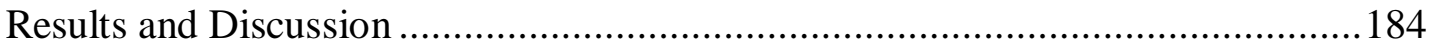

Multi-variable multi-objective function .................................................. 184

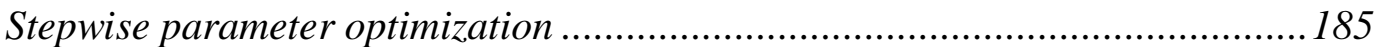

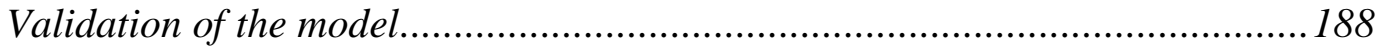

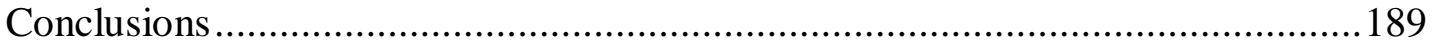

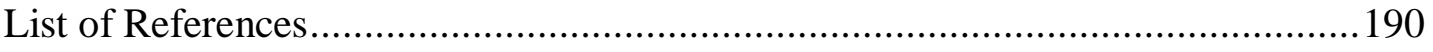

CONCLUSIONS ..................................................................................................204 


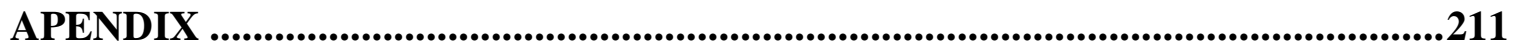

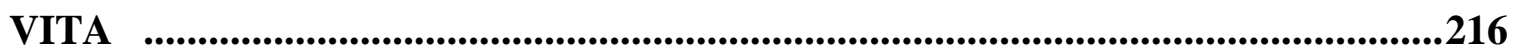




\section{LIST OF TABLES}

Table 3.1. Subarea parameters used to simulate crop areas and grass waterways of the three watersheds at the paired watershed study, Greenley Research Center, Missouri, USA.

Table 3.2. Model parameters used in calibration, the range tested, selected values, and their sensitivity rank (1-highest sensitivity) on model outputs of the three watersheds at the paired watershed study, Greenley Research Center, Missouri, USA.

Table 3.3. Agricultural Policy Environmental Extender (APEX) model performance for coefficient of determination $\left(r^{2}\right)$ and Nash-Sutcliffe Coefficient(NSC) values for event-based runoff, sediment, total nitrogen (TN), and total phosphorus (TP) for Center, West, and East watersheds at Greenley Research Center, Missouri, USA for calibration and validation.

Table 4.1. Subarea parameters used to simulate crop land, buffers, and grass waterways of the three watersheds at the paired watershed study, Greenley Research Center, Missouri, USA.

Table 4.2. Agricultural Policy Environmental Extender (APEX) model performance for coefficient of determination $\left(r^{2}\right)$ and Nash-Sutcliffe Coefficient(NSC) values for crop yield, event runoff and total phosphorus (TP) for agroforestry buffer, contour grass buffer, and control watersheds at Greenley Research Center, Missouri, USA for calibration (crop yields: 1998 to 2002; runoff, sediments, TN, and TP: events 1 to 14) and validation (crop yields: 2003 to 2008; runoff, sediments, TN, and TP: events 15 to 35).

Table 5.1. Details of watershed data used for calibration and validation of the fuzzy inference system.

Table 5.2. Most sensitive parameters used for runoff calibration for the APEX model.

Table 5.3. Chromosomes with and without genetic algorithm (GA) optimization, consisting x-coordinate values for Low (L), Medium low (ML), Medium (M), Medium high $(\mathrm{MH})$, and High $(\mathrm{H})$ membership functions for rainfall and runoff used for the fuzzy inference system for pre-buffer, agroforestry buffer and contour grass buffer watersheds.

Table 5.4. Model performance coefficients (coefficient of determination, $r^{2}$; NashSutcliffe Coefficient, NSC; and percent bias, Pbias) for fuzzy inference system (FIS) before and after genetic algorithm (GA) optimization and 
Agricultural Policy Environmental eXtender (APEX) model during calibration and validation for event-based runoff of watersheds prior to and after buffer treatments at the paired watershed study, Greenley Research Center, Missouri, USA.

Table 5.5. Fuzzy inference system performance with the increase of membership functions for both rainfall and runoff.

Table 5.6. Model calibration and validation of fuzzy inference system using varying number of events / years of historical data.

Table 5.7. Model performance indicators of Fuzzy inference system simulation of Long Branch watersheds in Macon and Adair Counties, Missouri, USA.

Table 6.1. Agricultural Policy Environmental Extender (APEX) model equations used for key processes for the watersheds at the at Greenley Research Center, Missouri.

Table 6.2. The Agricultural Environmental Policy and eXtender (APEX) model parameters and their values used for automatic optimization and calibration for different processes of the watersheds at Greenley Research Center, Missouri.

Table 6.3. Model performance coefficients: Coefficient of determination $\left(r^{2}\right)$ NashSutcliffe Coefficient (NSC), and Percent bias (Pbias) for Agricultural Environmental Policy and eXtender (APEX) model simulation of optimal parameter sets for runoff, sediment, biological activity, total phosphorous (TP), and total nitrogen (TN), selected by different multi-objective functions versus independent observations for the watersheds at Greenley Research Center, Missouri.

Table 6.4. The optimum parameter sets of runoff, sediment, biological activity, total phosphorous (TP), and total nitrogen (TN) selected by different multiobjective functions and independent observations during calibration of the Agricultural Environmental Policy and eXtender (APEX) model for the watersheds at the Greenley Research Center, Missouri.

Table 6.5. Agricultural Policy Environmental Extender model (APEX) performances for coefficient of determination $\left(r^{2}\right)$, Nash-Sutcliffe coefficient (NSC), and percent bias (Pbias) values for event-based runoff, sediment, total phosphorus (TP), and total nnitrogen (TN) predictions for Center, West, and East watersheds at Greenley Research Center, Missouri, for calibration and validation of manual versus automatic parameter optimization methods. 


\section{LIST OF FIGURES}

Fig. 2.1. Schematic diagram of functions of a buffer strip (Dorioz et al., 2006).

Fig. 3.1. Topographic map (0.5 m interval) of West, Center and East watersheds (a; After Udawatta et al., 2002). Grey lines represent contour lines (thin) and grass waterways (wide). The inset map shows the approximate location of the study site in Knox County, Missouri. ArcAPEX model delineated subareas and stream network of the three watersheds (b).

Fig. 3.2. Measured and simulated corn and soybean yields for Center (a), West (b), and East (c) watersheds during the study period at the paired watershed study, Greenley Research Center, Missouri, USA.

Fig. 3.3. Measured and simulated runoff for Center (a), West (b), and East (c) watersheds during the study period at the paired watershed study, Greenley Research Center, Missouri, USA. The Center (a) watershed shows the results for calibration while West (b), and East (c) watersheds show the results for validation. Please note that the $\mathrm{X}$-axis values are independent events and are not consecutive.

Fig. 3.4. Measured and simulated sediment losses for Center (a), West (b), and East

(c) watersheds during the study period at the paired watershed study, Greenley Research Center, Missouri, USA. The Center (a) watershed shows the results for calibration while while West (b) and East (c) watersheds show the results for validation. Measured sediment losses for events 18, 19, and 37 were not available. Please note that the $\mathrm{X}$-axis values are independent events and are not consecutive.

Fig. 3.5. Measured and simulated total nitrogen losses for Center (a), West (b), and East (c) watersheds during the study period at the paired watershed study, Greenley Research Center, Missouri, USA. The Center (a) watershed shows the results for calibration while West (b) and East (c) watersheds show the results for validation. Measured total nitrogen losses for events 18, 19, and 37 were not available. Please note that the $\mathrm{X}$-axis values are independent events and are not consecutive.

Fig. 3.6. Measured and simulated total phosphorous losses for Center (a), West (b), and East (c) watersheds during the study period at the paired watershed study, Greenley Research Center, Missouri, USA. The Center (a) watershed shows the results for calibration while West (b) and East (c) watersheds show the results for validation. Measured total phosphorous losses for events 18, 19, 
and 37 were not available. Please note that the $\mathrm{X}$-axis values are independent events and are not consecutive.

Fig. 3.7. APEX model predictions for average annual runoff, and average annual total phosphorous (TP) losses for Center ( $\mathrm{a}$ and d), West (b and e), and East ( $c$ and f) watersheds, respectively, at the paired watershed study, Greenley Research Center, Missouri, USA, for 10 and 20 years, with and without grass waterways....

Fig. 4.1. Topographic map (0.5-m interval) of West, Center and East watersheds (a; After Udawatta et al., 2004). Grey lines represent contour lines (thin) and grass waterways (wide). The inset map shows the approximate location of the study site in Knox County, Missouri. ArcAPEX model delineated subareas, and stream network of the three watersheds (b).

Fig. 4.2. Measured and simulated event-based runoff for Agroforestry buffer (a), Grass buffer (b), and Control (c) watersheds during the study period at the paired watershed study, Greenley Research Center, Missouri, USA. The events 1 to 14 (1998-2001) represent results for calibration while events 15 to 35 (2002-2008) represent results for validation of all three watersheds. Please note that the $\mathrm{x}$-axis values are independent events and are not consecutive.

Fig. 4.3. Measured and simulated event-based sediment for Agroforestry buffer (a), Grass buffer (b), and Control (c) watersheds during the study period at the paired watershed study, Greenley Research Center, Missouri, USA. The events 1 to 14 (1998-2001) represent results for calibration while events 15 to 35 (2002-2008) represent results for validation of all three watersheds. . Please note that the $\mathrm{x}$-axis values are independent events and are not consecutive.

Fig. 4.4. Measured and simulated event-based total phosphorous for Agroforestry buffer (a), Grass buffer (b), and Control (c) watersheds during the study period at the paired watershed study, Greenley Research Center, Missouri, USA. The events 1 to 14 (1998-2001) represent results for calibration while events 15 to 35 (2002-2008) represent results for validation of all three watersheds. Please note that the $\mathrm{x}$-axis values are independent events and are not consecutive.

Fig. 4.5. Measured and simulated event-based total nitrogen for Agroforestry buffer (a), Grass buffer (b), and Control (c) watersheds during the study period at the paired watershed study, Greenley Research Center, Missouri, USA. The events 1 to 14 (1998-2001) represent results for calibration while events 15 to 35 (2002-2008) represent results for validation of all three watersheds. . Please note that the $\mathrm{x}$-axis values are independent events and are not 
consecutive.

Fig. 4.6. APEX model predictions for average annual runoff (a), and average annual total phosphorous (b) losses for agroforestry and grass buffer watersheds, at the paired watershed study, Greenley Research Center, Missouri, USA, with different buffer widths of $4.5,5.5$, and $7.5 \mathrm{~m}$.

Fig. 4.7. APEX model predictions for average annual runoff and average annual total phosphorous for agroforestry buffer ( $\mathrm{a}$ and $\mathrm{b}$ ) and grass buffer ( $\mathrm{c}$ and d) watersheds, at the paired watershed study, Greenley Research Center, Missouri,USA, with varying buffers at summit, shoulder and back slope, and foot slope position of the watershed landscape.

Fig. 5.1. Topographic map (0.5-m interval) of West, Center and East watersheds before establishment of buffers (a; after Udawatta et al., 2004). Grey lines represent contour lines (thin) and grass waterways (wide). The inset map shows the approximate location of the study site in Knox County, Missouri. Map of Long Branch watershed with 300 and 301subwatersheds in Macon and Adair Counties, Missouri (b; after Udawatta et al., 2006). The inset map shows the approximate location of the Long Branch watersheds in, Missouri. ... 164

Fig. 5.2. Program flow of the geno-fuzzy model.

Fig. 5.3. Membership functions with and without genetic algorithm optimization for input variable "Rainfall" and for output variable "Runoff" used for fuzzy inference system for pre-buffer (a and b), post-buffer agroforestry (c and d) and post-buffer contour grass (e and f) watershed simulations. Data labels represent membership functions: L- low, ML- medium low, M-medium, $\mathrm{MH}$ medium high and $\mathrm{H}$ - High.

Fig. 5.4. Rainfall, measured event-based runoff, fuzzy logic (FL) and Agricultural Policy Environmental eXtender (APEX) model simulated event-based runoff for Center (a; 1993 to 1997; 42 events) and East (b; 1998 to 2008; 35 events) watersheds without buffers at the paired watershed study, Greenley Research Center, Missouri, USA. The Center (a) watershed shows the results for calibration while East (b) watershed shows the results for validation.

Fig. 5.5. Rainfall, measured event-based runoff, fuzzy logic (FL) and Agricultural Policy Environmental eXtender (APEX) model simulated event-based runoff for Center (a) and West (b) watersheds with agroforestry and contour grass buffers, respectively, at the paired watershed study, Greenley Research Center, Missouri, USA. Storm events 1 to 17 (1998 to 2001) were used for the calibration and events 18 to 35 (2002 to 2008) were used for validation for both watersheds. 
Fig. 5.6. Membership functions with and without genetic algorithm optimization for input variable "Rainfall" and for output variable "Runoff" used for fuzzy inference system for pre-buffer ( $a$ and b), post-buffer agroforestry (c and d) and post-buffer contour grass ( $\mathrm{e}$ and $\mathrm{f}$ ) watersheds when calibration and validation data were switched. Data labels represent membership functions: L- low, ML- medium low, M-medium, MH- medium high and $\mathrm{H}$ - High.

Fig. 6.1. Topographic map (0.5-m interval) of the West, Center, and East watersheds (adapted from Udawatta et al., 2002; a). Grey lines represent contour lines (thin) and grass waterways (wide). The inset map shows the approximate location of the study site in Knox County, Missouri. ArcAPEX model delineated subareas and stream network of the three watersheds (adapted from Senaviratne et al., 2013; b)....

Fig. 6.2. Program flow of the module for the multi-objective, multi-variable parameter optimization and calibration of Agricultural Environmental Policy and eXtender (APEX) model for the watersheds at Greenley Research Center, Missouri.

Fig. 6.3. Progress of the model performance coefficients of Coefficient of determination $\left(r^{2} ; \mathrm{a}\right)$, Nash-Sutcliffe Coefficient (NSC; b), and Percent bias (Pbias; c) during stepwise parameter optimization and calibration process of the Agricultural Environmental Policy and eXtender (APEX) model. 


\title{
APEX AND FUZZY MODEL ASSESSMENT FOR ENVIRONMENTAL BENEFITS OF AGROFORESTRY BUFFERS FOR CLAYPAN SOILS
}

\author{
G.M.M.M. Anomaa Senaviratne
}

\author{
Drs. Ranjith P. Udawatta and Stephen H. Anderson, Dissertation Supervisors.
}

\begin{abstract}
Agricultural non-point source pollution (NPSP) is a serious threat to the environment. The existence of an impervious claypan layer at shallow depths ( 0.1 to 0.5 m) of soils in three million hectares of Midwestern regions aggravates the problem of soil erosion and pollutant loadings from agricultural lands. A study conducted using a paired watershed design with no-till corn (Zea mays L.)-soybean [Glycine max (L.) Merr.] rotation in Northeast Missouri, has shown 11-35\% reduction in measured sediment and nutrient loads 11 years after establishment of agroforestry (grass+trees) and grass upland contour buffers ( $4.5 \mathrm{~m}$ width). Continuation of in situ studies at the watershed scale to evaluate site specific factors such as optimum buffer dimensions and strategic placement of buffers incur significant additional costs, become complex, and require significant time commitments. Hydrologic models provide a convenient, efficient, and economically feasible alternative method to evaluate the impact of buffer dimensions and placement on reduction of NPSP. Two broad categories of hydrologic models are: data-driven, empirically-based models and physically driven, process-based models. Physically-based models simulate real world processes using large amounts of field measured data and
\end{abstract}


provide advanced tools for hydrological analysis. Data driven models are built on historical relationships of data and use a range of techniques such as simple regression to advanced artificial intelligent techniques. Data driven models provide alternative tools when detailed physical modeling is not required or not possible due to limited availability of physical data. The present study evaluates both types of models: a physically-based distributed Agricultural Policy Environmental Extender (APEX) model developed for farms or small scale watersheds and a data-driven fuzzy logic model. This research simulates the long-term effects of permanent upland contour buffers consisting of grass only and grass+trees (agroforestry) on pollutant loadings. The current work was divided in to four independent studies leading to four manuscripts.

Study 1 used the APEX model to simulate the three adjacent field-size row-crop watersheds during the calibration period (1991-1997) of the paired watershed study. The watersheds had only grass waterways during the calibration period and were identified as East, Center, and West. The objective of study 1 was to conduct a sensitivity analysis to determine the effect of model parameters on APEX output, and then use the parameterized, calibrated, and validated model to evaluate long-term benefits of grass waterways of the three watersheds prior to the establishment of upland buffers. Twentyseven APEX model parameters were found to be sensitive for crop yield, runoff, sediment, nitrogen (dissolved and total), and phosphorous (dissolved and total) simulations. The model was calibrated using measured event-based data from the Center watershed from 1993 to 1997 and validated with data from the West and East watersheds. Simulated crop yields were within $\pm 13 \%$ of the measured yield. The model performance 
for event-based runoff was excellent, with coefficients of determination $\left(r^{2}\right)>0.9$ and Nash-Sutcliffe coefficients (NSC) $>0.8$ for calibration and validation. Sediment and total nitrogen $(\mathrm{TN})$ calibration results were satisfactory for larger rainfall events $(>50$ mm) with $r^{2}>0.5$ and NSC $>0.4$ but validation results remained poor with NSC between 0.18 and 0.3 . The model was well calibrated and validated for total phosphorous (TP) with $r^{2}>0.8$ and NSC $>0.7$. Presence of grass waterways reduced annual TP loadings by $13-25 \%$. The replicated study indicates that APEX provides a convenient and efficient tool to evaluate long-term benefits of conservation practices.

Study 2 was undertaken to use the APEX model to simulate the watersheds after the buffer treatments. In 1997, grass and agroforestry buffers, and control treatments were randomly established in West, Center, and East watersheds, respectively. The objective of this study was to calibrate and validate the APEX model for the study watersheds and find optimum buffer dimensions, placement locations, and effect of a winter cover crop. ArcAPEX and APEX0604 versions were used for the simulations. The simulated corn and soybean yields were within $\pm 15 \%$ of the Pbias values except for the validation by the Control watershed. The agroforestry, grass buffer, and control watershed models were calibrated (1998 to 2001) and validated (2002 to 2008) for eventbased runoff with $r^{2}$ and Nash-Sutcliffe Coefficients (NSC) values of 0.7-0.8 and 0.4-0.8, respectively. They were calibrated and validated for event-based total phosphorous (TP) with $r^{2}$ and NSC ranging 0.5-0.8 and 0.4-0.7, respectively. The model could not be calibrated for sediments and total nitrogen. The simulated grass and agroforestry buffers reduced average annual runoff by 4 and 5\% and annual TP loadings by $13 \%$ and $45 \%$, 
respectively. An increase in buffer widths from 4.5 to 5.5 and $7.5 \mathrm{~m}$ did not effectively change runoff or TP loads. Placement of buffers in backslope positions was a little more effective for reducing runoff and TP loads in the agroforestry watershed. Simulation of a winter wheat (Triticum hybernum) cover crop reduced TP loadings by $12 \%$ to $19 \%$. The calibrated and validated APEX model may be used to simulate effects of upland contour agroforestry and grass buffers to determine environmental benefits of buffers.

Study 3 was undertaken with the objective to develop a fuzzy inference system (FIS) with genetic algorithm (GA) optimization for membership functions (MFs) for event-based rainfall-runoff prediction of three small adjacent row-crop watersheds $(1.65$ to 4.44 ha) with intermittent discharge in the claypan soils of Northeast Missouri, prior to and after the establishment of upland contour grass and agroforestry (tree+grass) buffers. A Mamdani type FIS with five MFs and five fuzzy rules was created using MATLAB 7.10.0. Two sets of MFs were developed and optimized using GA for pre- and post-buffer conditions using the Center watershed. The pre-buffer model was validated with post-buffer data of the Control watershed. The post-buffer model was calibrated and validated by dividing the post-buffer period into two. The FIS simulated event-based runoff with $r^{2}$ and NSC values greater than 0.65 for calibration and validation. These values were similar to those of the physically-based Agricultural Policy Environmental eXtender model $\left(r^{2}\right.$ and NSC > 0.65) for the same watershed data. The pre-buffer FIS simulated event-based runoff of two larger watersheds with similar management (140 ha and 259 ha) with $r^{2}$ values of 0.82 and 0.68 and NSC values of 0.77 and 0.53 . The GA optimization of MFs improved $r^{2}$ and NSC values by 0.01 to 0.1 . The 
physically-based hydrological model requires extensive input data and FIS offers an alternate modeling tool for runoff estimation in the absence of detailed watershed data.

Study 4 was undertaken with the objective to develop and evaluate a stepwise progressive parameter optimization technique with minimal computational cost for automatic calibration of the Agricultural Environmental Policy and eXtender (APEX) model for runoff, sediment, total phosphorous (TP) and total nitrogen (TN) loading. Twenty-three parameters and their ranges for calibration were determined based on previous sensitivity analysis and a study on three adjacent row-crop field-size watersheds located in Northeast Missouri. A notebook computer (2.2 GHz, 4GB RAM) and MATLAB 7.10.0. code was used to automatically: create parameter sample populations, execute the APEX model for each set of parameters, calculate multi-objective, multivariable functions based on calculated outputs and measured values, and calibrate the model. The objective functions based on Generalized Likelihood Uncertainty Estimation (GLUE), and combinations of the coefficient of determination $\left(r^{2}\right)$, the regression slope and the Nash Sutcliffe coefficient (NSC), were evaluated for their relative applicability. The parameters were grouped according to their impact on: runoff (5), sediment (5), biological soil properties (4), TP (4) and TN (5). Each set of parameters was separately and consecutively optimized for progressive calibration of the model. The values of each parameter were limited to two to nine discrete values to reduce the number of parameter combinations for model runs. Runoff predictions were not affected by the optimization compared to the manual calibration values of the previous study. However, runoff parameter optimization resulted in $31 \%, 7 \%$ and $14 \%$ increases in $r^{2}$ values, and $3 \%, 7 \%$ 
and 9\% increases in NSC values, for sediment, TP and TN, respectively. The largest improvements in NSC values were observed for TP after optimization for soil biological (15\%) and P parameters (25\%). The objective function based on the GLUE selected the optimum parameter set or close to it for all output variables except for the sediment for which the objective function based on $r^{2}$, slope and NSC provided the best selection. Step-wise parameter optimization after initial manual model calibration proved to offer an alternate technique for automatic calibration and validation of the APEX model with minimum computational cost.

The studies using APEX model indicated that the model could be used for quantifying the environmental benefits of grass waterways, agroforestry and grass contour upland buffers provided they are sufficiently parameterized, calibrated, and validated with reasonable long-term measured data. Multi-variable, multi-objective parameter optimization offers a promising tool to calibrate the model especially for the runoff parameters which was essential for proper calibration of sediment, TP, and TN. The fuzzy logic model offers a reasonable alternative for runoff predictions when detailed modeling is not required or availability of physical details of the watershed is limited. 


\section{CHAPTER}

\section{INTRODUCTION}

According to the latest report of the U.S. Environment Protection Agency (USEPA, 2013), $52 \%$ of rivers and streams $(1,583,735 \mathrm{~km})$ and $68 \%$ of lakes, reservoirs and ponds $(4,888,454$ ha) in the U.S. are impaired. A report by the Missouri Department of Natural Resources (2012), highlights that $54 \%$ of Missouri rivers and streams $(8,755$ $\mathrm{km} ; 22.3 \%$ rivers and streams assessed) and 35\% of lakes (28,222 ha; $23 \%$ lakes assessed) do not meet water quality standards. The main sources of impairment of rivers and streams have been found to be pathogens, sediments, nutrients, and chemicals originating from agricultural lands. According to the U.S. Department of Agriculture (USDA-NRCS, 2007), soil erosion by water on crop land has been reduced from 1.68 billion tons per year in 1982 to 960 million tons per year in 2007 (43\% reduction). Sixty-two percent of crop land in Missouri are still loses soil above the tolerance level of 7.6 $\mathrm{Mg} \mathrm{ha}^{-1}$ (USDA-NRCS, 2000).

Existence of a claypan in the subsoils of northeastern Missouri enhances surface runoff and surface transport of sediment, nutrients, and herbicides (National Academy of Sciences, 1986; USDA-NRCS, 2000). Claypan soils are characterized by an abrupt increase $(100 \%)$ in clay content within 0.1 to 0.5 -m depth compared to the top layer with clay content varying from 350-600 $\mathrm{g} \mathrm{kg}^{-1}$ (Miles and Hammer, 1989; Blanco-Canqui et al., 2002; USDA-NRCS, 2006). These soils are distributed over three million hectares 
in Missouri, Illinois, and Kansas (Jamison et al., 1968; Anderson et al., 1990; USDANRCS, 2006). Presence of the high shrink-swell, smectitic clay in the subsoil argillic horizons of these soils results in low saturated hydraulic conductivity, poor infiltration, and high runoff potential (Blanco-Canqui et al., 2002).

Conservation measures and practices that preserve soil, minimize the need for chemical fertilizers and pesticides, and reduce runoff can significantly improve water quality (McDowell et al., 2002; Sharpley et al., 2003). Practices such as no-till agriculture (McDowell et al., 2002), crop rotation, incorporation of perennial crops to crop rotations (Jackson and Jackson, 2002;), nutrient management (Sharpley et al., 2003), integrated pest management (Logan, 1993), and conservation buffers have resulted in significant reductions in soil erosion. Buffer filter strips are permanent vegetation established within and between agricultural fields intended to intercept and slow runoff, and filter sediments and nutrients (Lowrance et al., 1984; Dillaha et al., 1989; Schmitt et al., 1999; Udawatta et al., 2002; 2011; Franti et al., 2004; Helmers et al., 2005; Dosskey et al., 2007; Sabbagh et al., 2009). Inclusion of trees and / or shrubs in such vegetation is known as agroforestry practices and has been shown to improve water and soil quality by reducing NPSP losses from agricultural land.

The present study is a continuation of a long-term monitored paired watershed study conducted at the Greenley Memorial Research Center in Knox County, Missouri with upland contour agroforestry and contour grass strips incorporated within cropland with corn (Zea mays, L.)-soybean (Glycine max (L.) Merr.) rotations (Udawatta et al., 
2002). During the treatment period (1998 to 2003), the agroforestry and grass buffers reduced runoff by $1 \%$ to $10 \%$, total phosphorous loads by $3.7-26 \%$, and total nitrogen loads by $21 \%$ and $20 \%$. During the period from 2004 to 2008, grass and agroforestry buffers reduced runoff by $23 \%$ and $15 \%$, sediment losses by $28 \%$ and $30 \%$, total nitrogen losses by $13 \%$ and $11 \%$ and total phosphorous losses by $22 \%$ and $26 \%$, respectively (Udawatta et al., 2011). This long-term study has already proven that the establishment of grass and agroforestry buffers improves water quality by reducing runoff, sediments and nutrient loadings from row-crop watersheds with claypan soils and the effects increased through the years of establishment. Other studies conducted at the same watersheds have shown that the agroforestry and grass buffers improved soil porosity (Udawatta et al., 2006) with the presence of dense and deep root systems, increased the water storage capacity, and improved soil hydraulic parameters (Seobi et al., 2005). Agroforestry buffers also enhance microbial communities (Udawatta et al., 2008, 2009; Paudel et al., 2011) and provide fine root systems that trap particulates and assimilate dissolved nutrients (Udawatta et al., 2008; Kumar et al., 2010b). However, these authors emphasized the necessity of having site specific factors such as appropriate widths, density, and strategic placement of buffers to obtain optimum benefits.

In situ studies at the watershed scale have inherent problems such as high costs, complex nature of land ownership, and time taken to show results (Mulla et al., 2005). Sharpley et al. (2003) stated that hydrologic models provide a convenient, efficient, and economically feasible method to evaluate nutrient loading mechanisms under various management systems provided sufficient measured data are available at the small 
watershed scale. Numerous models have been developed for watershed hydrology, which may be categorized as data-driven empirically based models or physically driven process based models that reproduce the system and its behavior in a physically realistic manor (Lohani et al., 2010).

The Agricultural Policy Environmental eXtender (APEX) model (Williams et al., 1998) is an extension of the Environmental Policy Integrated Climate (EPIC) model (Williams, 1990) and is a physically based, distributed, continuous, daily time-step model developed for farm or small watershed hydrology and water quality assessment. The APEX model has the feature of flow simulation and sediment and nutrient routing between multiple fields, called "subareas" and "channel systems," to the watershed outlet (Srivastava et al., 2007). The model is also capable of simulating innovative management practices such as filter strips and grass waterways (Williams et al., 2006). The APEX model has been selected for national scale studies to evaluate effectiveness of vegetative filter strips in controlling sediment and pollutants (Arnold et al., 1998) and to evaluate the benefits of the conservation programs of the United States Department of Agriculture-Natural Resources Conservation Service (USDA-NRCS) by the Conservation Effects Assessment Project (CEAP; Wang et al., 2006).

Physically-based hydrologic models require a significant amount of topographic, meteorological, and hydrological data for proper set up, calibration and validation of the model (Blasone et al., 2008). Rigorous parameterization and calibration of the model is carried out to assert robustness of the model. Blasone et al. (2008) cautioned that over- 
parameterization could lower the degree of reliability of the model predictions and suggested that the dimensions of the parameter space could be reduced by conducting sensitivity analyses (SA) on model outputs. It has also been emphasized that the model should be validated not only with time but also on multiple sites (Blasone et al., 2008) and at different scales (Vazquez et al., 2002; Vazquez and Feyen, 2007). The models needs to be optimized for multiple objectives of multiple output variables, e.g. flow, sediment, and nutrients. (Gupta and Sorooshian, 1998; Gupta et al., 1998, 1999).

Physically-based, distributed models not only require large amounts of site specific data but also take significant time for construction (Lohani et al., 2010; Sen, 2009). Physically-based models also rely heavily on assumptions such as linearity at the scale considered for non-linear relationships such as the Soil Conservation Service (SCS) curve number equation for example (Beven, 2001). Thus, researchers are looking into alternative modeling techniques that do not require physical details of the watershed and / or detailed modeling. The concept of fuzzy reasoning put forward by Zadeh (1965) facilitates the incorporation of vague, imprecise, and incomplete information typical to the natural environment, into a reason-base decision making system. Fuzzy logic (FL) models also facilitate the incorporation of the expert understanding of the hydrologist into the model in terms of linguistic information which classical systems are incapable. Although application of FL in hydrology is in its initial stages, several studies have used FL for hydrological assessment of watersheds and water quality studies. In several studies, FL models proved better than conventional methods in predicting runoff (Barreto-Neto and Filho, 2008; Guertin et al., 2000; Silvert, 2000). 


\section{Objectives}

The goal of this study was to use and optimize the predictability of APEX and fuzzy models to evaluate the environmental benefits of grass waterways, upland contour agroforestry and grass buffers and winter cover crops on reduction of NPSP of three adjacent corn-soybean rotation watersheds in claypan soils. The objectives of this study were evaluated under four sub-studies as outlined below.

Study 1- This study was entitled "Agricultural Policy Environmental eXtender simulation of three adjacent row-crop watersheds in the claypan region". The specific objectives were to: (1) conduct a parameter sensitivity analysis to examine the effect of model parameters on model output and model performances of crop yield, runoff, sediment, total nitrogen (TN), dissolved nitrogen (DN), total phosphorous (TP), and dissolved phosphorus (DP); (2) parameterize, calibrate, and validate the model for crop yield, runoff, sediment, $\mathrm{TN}$, and TP of the paired watersheds during the period prior to the establishment of grass and agroforestry buffers, and (3) quantify the long-term reductions in runoff and TP from grass waterways.

Study 2 - This study was entitled "Agricultural Policy Environmental eXtender simulation: Environmental benefits of agroforestry and grass buffers on cornsoybean watersheds". The specific objectives were to: (1) calibrate and validate the APEX model for crop yields, runoff, sediment, total nitrogen, and total phosphorous for agroforestry, grass buffer and control watersheds, (2) use the 
calibrated model to investigate the effects of varying buffer width and placement on NPSP reductions, and (3) evaluate the effect of a winter cover crop on the benefits of NPSP reductions.

Study 3- This study was entitled "Performance of geno-fuzzy model on rainfall-runoff predictions in claypan watersheds". Its specific objectives were to: (1) develop a fuzzy inference system (FIS) by defining fuzzy membership functions for input rainfall and output runoff variables and a fuzzy rule (FR)-base, (2) to calibrate the model using genetic algorithm (GA) optimization for membership functions (MFs) and validate the model, (3) compare the results with results from a previous study using the physically-based model, APEX for the same watersheds during the same period (objective 2), and (4) test applicability of the FIS model on two larger watersheds with similar conditions.

Study 4- This study was entitled "Multi-variable, multi-objective stepwise parameter optimization method for Agricultural Environmental Policy eXtender model”. Its specific objectives were to: (1) develop and evaluate a stepwise progressive parameter optimization technique with minimal computational cost for automatic calibration of the APEX model for runoff, sediment, total phosphorous (TP) and total nitrogen (TN) loading, and use the optimized parameters to validate the model, and (2) to compare the results with findings of study1. 


\section{List of References}

Barreto-Neto, A.A., and A.R. de S. Filho. 2008. Application of fuzzy logic to the evaluation of runoff in a tropical watershed. Environ. Model. Softw. 33(2): 244253.

Beven, K.J. 2001. Dalton Medal Lecture: How far can we go in distributed hydrological modelling? Hydrol. Earth Syst. Sci. 5(1): 1-12.

Blasone, R.S., H. Madsen, and D. Rosbjerg. 2008. Uncertainty assessment of integrated distributed hydrological models using GLUE with Markov chain Monte Carlo sampling. J. Hydrol. 353(1): 18-32.

Dillaha, T.A., R.B. Renear, S. Mostaghimi, and D. Lee. 1989. Vegetative filter strips for agricultural nonpoint source pollution control. Trans. ASAE 32: 513-519.

Dosskey, M.G., K.D. Hoagland, and J.R. Brandle. 2007. Change in filter strip performance over ten years. J. Soil Water Conserv. 62(1): 21-32.

Franti, T.G., D.E. Eisenhauer, M.C. McCullough, L.M. Stahr, M. Dosskey, D.D. Snow, R.F. Spalding, and A.L. Boldt. 2004. Watershed scale impacts of buffers and upland conservation practices on agrochemical delivery to streams. Available at http://digitalcommons.unl.edu/usdafsfacpub/25/ (verified 19 October 2012).

Guertin, D.P., S.N. Fiedler, S.N. Miller, and D.C. Goodrich. 2000. Fuzzy logic for watershed assessment. In Proc. of the ASCE Conf erence on Science and Technology for the New Millennium, June 21-24. Collins, CO.

Gupta, H.V., S. Sorooshian, and P.O. Yapo. 1998. Toward improved calibration of hydrologic models: Multiple and noncommensurable measures of information. Water Resour. Res. 34(4): 751-763.

Gupta, H.V., S. Sorooshian, and P.O. Yapo. 1999. Status of automatic calibration for hydrologic models: Comparison with multilevel expert calibration. J. Hydrol. Eng. 4(2): 135-143.

Helmers, M.J., D.E. Eisenhauer, M.G. Dosskey, T.G. Franti, J.M. Brothers, and M.C. McCullough. 2005. Flow pathways and sediment trapping in a field-scale vegetative filter. Available at http://ddr.nal.usda.gov/handle/10113/5504 (verified 26 March 2013).

Jackson, D.L., and L. Jackson. 2002. The Farm as natural habitat: Reconnecting food systems with ecosystems. Island Press, 1718, Connecticut Avenue, N.W.., Siute 300, Washington DC.

Kumar, S., S.H. Anderson, and R.P. Udawatta. 2010a. Agroforestry and Grass Buffer 
Influences on Macropores Measured by Computed Tomography under Grazed Pasture Systems. Soil Sci. Soc. Am. J. 74(1): 203.

Kumar, S., R.P. Udawatta, and S.H. Anderson. 2010b. Root length density and carbon content of agroforestry and grass buffers under grazed pasture systems in a Hapludalf. Agrofor. Syst. 80(1): 85-96.

Kumar, S., S.H. Anderson, R.P. Udawatta, and R.L. Kallenbach. 2012. Water infiltration influenced by agroforestry and grass buffers for a grazed pasture system. Agrofor. Syst. 84(3): 325-335.

Logan, T.J. 1993. Agricultural best management practices for water pollution control: current issues. Agric. Ecosyst. Environ. 46(1): 223-231.

Lohani, A.K., N.K. Goel, and K.K.S. Bhatia. 2010. Comparative study of neural network, fuzzy logic and linear transfer function techniques in daily rainfallrunoff modelling under different input domains. Hydrol. Process. 25(2): 175193.

Lowrance, R.R., R.L. Todd, J. Fail, O. Hendrickson, R. Leonard, and L.E. Asmussen. 1984. Riparian forests as nutrient filters in agricultural watersheds. J. Biosci. 34: 374-377.

McDowell, R.W., A.N. Sharpley, and P.J.A. Kleinman. 2002. Integrating phosphorous and nitrogen decision managment at watershed scales. Jawra J. Am. Water Resour. Assoc. 38(2): 479-491.

Missouri Department of Natural Resources. 2012. Missouri water quality report (Section 305(b) report). Available at http://www.dnr.mo.gov/env/wpp/waterquality/305b/2012-305b.pdf (verified 30 March 2013).

Mulla, D.J., A.S. Birr, N.R. Kitchen, and M.B. David. 2005. Evaluating the effectiveness of agricultural management practices at reducing nutrient losses to surface waters. p. 171-193. In Proc. of the Gulf hypoxia and local water quality concerns. Iowa state university. Ames. Iowa.

Paudel, B.R., R.P. Udawatta, and S.H. Anderson. 2011. Agroforestry and grass buffer effects on soil quality parameters for grazed pasture and row-crop systems. Appl. Soil Ecol. 48(2): 125-132.

Sabbagh, G.J., G.A. Fox, A. Kamanzi, B. Roepke, and J.Z. Tang. 2009. Effectiveness of vegetative filter strips in reducing pesticide loading: Quantifying pesticide trapping efficiency. J. Environ. Qual. 38(2): 762-771. 
Schmitt, T.J., M.G. Dosskey, and K.D. Hoagland. 1999. Filter strip performance and processes for different vegetation, widths, and contaminants. J. Environ. Qual. 28(5): 1479-1489.

Sen, M. 2009. Fuzzy Logic and hydrology modeling. CRC Press, Taylor \& Francis group, Broken Sound Parkway, NW.

Seobi, T., S.H. Anderson, R.P. Udawatta, and C.J. Gantzer. 2005. Influence of grass and agroforestry buffer strips on soil hydraulic properties for an Albaqualf. Soil Sci. Soc. Am. J. 69(3): 893-901.

Sharpley, A.N., J.L. Weld, D.B. Beegle, P.J.A. Kleinman, W.J. Gburek, P.A. Moore Jr., and G. Mullins. 2003. Development of phosphorus indices for nutrient management planning strategies in the United States. J. Soil Water Conserv. 58: $137-152$.

Silvert, W. 2000. Fuzzy indices of environmental conditions. Ecol. Model. 130(1): 111119.

Udawatta, R.P., J.J. Krstansky, G.S. Henderson, and H.E. Garrett. 2002. Agroforestry practices, runoff, and nutrient loss. J. Environ. Qual. 31(4): 1214-1225.

Udawatta, R.P., S.H. Anderson, C.J. Gantzer, and H.E. Garrett. 2006. Agroforestry and Grass Buffer Influence on Macropore Characteristics. Soil Sci. Soc. Am. J. 70(5): 1763.

Udawatta, R.P., R.J. Kremer, B.W. Adamson, and S.H. Anderson. 2008. Variations in soil aggregate stability and enzyme activities in a temperate agroforestry practice. Appl. Soil Ecol. 39(2): 153-160.

Udawatta, R.P., R.J. Kremer, H.E. Garrett, and S.H. Anderson. 2009. Soil enzyme activities and physical properties in a watershed managed under agroforestry and row-crop systems. Agric. Ecosyst. Environ. 131(1-2): 98-104.

Udawatta, R.P., H.E. Garrett, and R. Kallenbach. 2011. Agroforestry buffers for nonpoint source pollution reductions from agricultural watersheds. J. Environ. Qual. 40(3): 800-806.

USDA-NRCS, U.S.D. of A.-N.R.C.S. 2007. Summary Report 2007 National Resources Inventory. Available at http://www.nrcs.usda.gov/Internet/FSE_DOCUMENTS/stelprdb1041379.pdf (verified 30 March 2013).

USEPA, (U.S. Environmental Protection Agency). 2013. National Summary of State Information. Available at 
http://ofmpub.epa.gov/waters10/attains_nation_cy.control\#status_of_dataon_cy.c ontrol (verified 30 March 2013).

Vazquez, R.F., L. Feyen, J. Feyen, and J.C. Refsgaard. 2002. Effect of grid size on effective parameters and model performance of the MIKE-SHE code. Hydrol. Process. 16(2): 355-372.

Vazquez, R.F., and J. Feyen. 2007. Assessment of the effects of DEM gridding on the predictions of basin runoff using MIKE SHE and a modelling resolution of 600m. J. Hydrol. 334(1-2): 73-87.

Wang, X., S.R. Potter, J.R. Williams, J.D. Atwood, and T. Pitts. 2006. Sensitivity analysis of APEX for national assessment. Trans.-Am. Soc. Agric. Eng. 49(3): 679.

Williams, J.R., J.G. Arnold, R. Srinivasan, and T.S. Ramanarayanan. 1998. APEX: A new tool for predicting the effects of climate and $\mathrm{CO} 2$ changes on erosion and water quality. Model. Soil Eros. Water 1: 441-449.

Williams, J.R., W.L. Harman, M. Magre, U. Kizil, J.A. Lindley, G. Padmanabhan, and E. Wang. 2006. APEX feedlot water quality simulation. Trans. Asae 49(1): 6173.

Zadeh, L.A. 1965. Fuzzy sets. Inform. Control 8: 338-353. 


\section{CHAPTER}

\section{LITERATURE REVIEW}

\section{Soil Erosion and Non-Point Source Pollution (NPSP)}

The primary agricultural NPSP consists of sediments, nutrients, animal wastes, and pesticides (USEPA, 2013). Sediment loading caused by soil erosion not only pollutes water resources but also deteriorates soil nutrient status causing a decrease in the productive capacity of the land. Pimental (2006) reported that $30 \%$ of the world's arable land has become unproductive over the past 40 years resulting in $\$ 400$ billion loss of productivity worldwide due to soil erosion. The cost of loss of productivity due to reduction in arable land in the U.S. alone is nearly $\$ 37.6$ billion per year (Pimental, 2006). Soil loss is 10 to 40 times faster than the rate of renewal (Pimental, 2006). This researcher states that it only takes one storm event to wash away $1 \mathrm{~mm}$ of top soil (13 tons per hectare), but it takes 20 years of natural processes to replenish it. A report by the Missouri Department of Natural Resources (2012) states that conservation programs over the past 23 years have reduced 147.6 million metric tons of soil from eroding. However, 2 million ha still lose 11.8 metric tons per ha per year which is above the acceptable level. The erosion from agricultural land in the state amounts to 51 million metric tons of soil per year (Missouri Department of Natural Resources, 2012). Nearly $60 \%$ of the eroded soil ends up in rivers, streams, and lakes making them impaired with soil bound nutrients and pesticides (Pimental et al., 1995; 2006). Suspended solids from sediments in water bodies reduce the amount of sunlight availability for aquatic plants, 
disturb fish spawning areas and coral reefs, and harm gel-fish leading to a gradual decrease in all aquatic life (USEPA, 2013). In addition, filling up of the water bodies by sediments also make them more prone to floods.

The existence of claypans in the subsoil enhances surface runoff and surface transport of sediments, nutrients, and herbicides (National Academy of Sciences, 1986; USDA/NRCS, 2000; Lerch and Blanchard, 2003). Often the clay content of the claypan horizon exceeds $60 \%$ and the clay fraction contains a large proportion of smectitic clay. The high shrink-swell potential of smectitic clay minerals results in very low saturated hydraulic conductivity, leading to poor infiltration and high rates of runoff (BlancoCanqui et al., 2002). In shrink/swells soils, deep cracks form in the topsoil as the soil dries and shrinks. By-pass flow is the infiltration of water occurring through these seasonal cracks created due to shrink-swell behavior of soils. This also reduces the opportunity for degradation of chemicals within the soil (Chen et al., 2001; Kazemi et al., 2008). The seasonal cracking of soils has become problematic in accurate prediction of runoff and infiltration in simulation models due to changing soil moisture storage conditions (Smettem et al., 1991; Stolte et al., 1997; Ruan and Illangasekare, 1998).

High soil erosion rates and nutrient losses by leaching and runoff also have been linked to agricultural practices such as monoculture row-cropping and deep tillage. Both processes expose soil to the mechanical disturbances of wind and water and lead to the depletion of organic matter which in turn destabilizes soil particles (Montgomery, 2007). Nitrogen $(\mathrm{N})$ and phosphorous $(\mathrm{P})$ are the major growth limiting nutrients of 
many agricultural crops and they are consequently applied as fertilizers in quantities often greater than the crop can use. Nitrogen and phosphorous are major nutrients that degrade water quality originating from agricultural land. Nutrients are applied to agricultural land in the form of commercial fertilizers manure from animal wastes or legumes and crop residues. The crop often uses only $45-50 \%$ of the applied nutrients (Nair and Gractz, 2004) and the rest is available for surface runoff, leaching, and volatilization losses (Bockman et al., 1990). Because of high solubility, fertilizer based $\mathrm{N}$ in the form of nitrate is easily transported with runoff water (Burt et al., 1993). Nitrogen from organic sources which makes up around $90 \%$ of total $\mathrm{N}$ in most soils also produce nitrate during mineralization processes (Stevenson, 1982; Adeuya et al., 2005). Nitrogen in the form of organic matter can also be transported as sediments in runoff. Even well managed cropland is reported to lose $40-60 \%$ of applied nitrogen (Galloway et al., 2002). Phosphorous exists in the form of dissolved $\mathrm{P}$ as well as particulate $\mathrm{P}$ in agricultural soils and erosion control measures have shown reductions in total $\mathrm{P}$ as well as particulate $\mathrm{P}$ losses (Dorioz et al., 2006). However, significant concentration of dissolved $\mathrm{P}$ has been found in runoff where soil erosion has been kept to a minimum, particularly when soil $\mathrm{P}$ content is high or has received $\mathrm{P}$ from recent fertilizer applications (Daverede et al., 2003). The levels of sediment, nitrate and soluble reactive phosphorous in streams have been positively correlated with row-crop agriculture in a study to evaluate effects of land use on water quality in an agricultural watershed (Mitsch et al., 2001). Another study has found that sediment loads resulting from largely agricultural watersheds were up to ten times greater than those from forested 
watersheds (Allan et al., 2003). However, effects of agriculture on water quality vary with physical conditions including climate, soils, subsurface geology, and topography, as well as cultural practices including crops grown, tillage methods used, chemicals applied and conservation practices in place, such as riparian forest buffer strips (Anderson et al., 2002).

\section{Soil Conservation}

The earliest U.S conservation efforts were initiated through the creation of the USDA-Soil Conservation Service (SCS) in 1935 by Public Law 46 which made financial and technical assistance available to farmers for conservation to reduce soil erosion (USDA/NRCS, 2004). The next important step was in 1977, when the US Congress passed the Soil and Water Resources Conservation Act to appraise and advance existing conservation efforts (USDA/NRCS, 2004). The Farm Security and Rural Investment Act of 2002 (Farm Bill) is hailed as the landmark legislation for increased conservation funding and for focusing on environmental issues (Helms, 2003). Through the passage of time, conservation specialists have put forward a multitude of alternative conservation practices for traditional farming and are being implemented through numerous conservation programs.

Conservation measures and practices that preserve soil, minimize the need for chemical fertilizers and pesticides, and reduce runoff can significantly improve water quality. Practices such as no-till agriculture (McDowell et al., 2002), crop rotations, incorporation of perennial crops to crop rotations (Jackson and Jackson, 2002;), nutrient 
management (Sharpley et al., 2003), integrated pest management (Logan, 1993), and conservation buffers have brought significant reductions in soil erosion and NPSP. In the practice of no-till, the previous year's residue is left on the field and no-till planters are used to plant directly into crop residue (Maskina et al., 1993). No-till agriculture has reduced erosion up to $94 \%$ in some instances, which in turn could substantially reduce $\mathrm{P}$ losses, as nearly 75-90\% of P losses are in soil bound forms (McDowell et al., 2002). The crop residue protects the soil from mechanical disturbances as well as provides organic matter that enhances soil aggregation (Udawatta et al., 2008) and water retention capacities, both of which reduce runoff, sediments and nutrient losses to aquatic systems (Holland and Coleman, 1987; Sharpley et al., 1992; Hansen et al., 2002). Though no-till practices offer significant reductions in erosion and nutrient losses, they should be used with proper nutrient management techniques in order to reduce ground water contamination by improved infiltration of water (Sharpley, 1992). Crop rotation with perennial legumes decreases the amount of fertilizer required to be applied as well as sequesters nitrogen, and releases it slowly to the environment through gradual mineralization after incorporation into soils (Jackson, 2002). This has led to nearly 50\% reduction in nitrogen leaching (Drinkwater et al., 1998). Perennials which propagate from roots each year rather than seeds incorporated into row-crops such as corn and soybeans can significantly reduce erosion, runoff, and leaching, because the plant litter, crowns, and roots remain in place from year to year, protecting the soil (Jackson, 2002). Nutrient management involves adjusted nutrient inputs based on the estimated production level, soil testing, irrigation water testing, and $\mathrm{N}$ credits from atmospheric 
deposition, manure, crop residue, legume crops, and applied nutrients in the forms of injection, split application, and additions with nitrogen stabilizers. Conservation practices such as reduced-tillage, no-till cultivation, crop rotation with legumes or perennial crops, nutrient management, and integrated pest management, cover crops and conservation buffers have been effective in reducing the high soil erosion rates for claypan soils.

Despite greater reductions in soil loss over the past several decades, NPSP continues to be a serious threat to the surface waters of the U.S. (USEPA, 2013). One of the main reasons for continued NPSP is that land owners lack financial support to implement conservation practices and these practices at times have not been effective, efficient or economical (Knowler and Bradshaw, 2007). Most of the conservation practices that were introduced by the conservation programs have been well tested at smaller plot and field scales (Brussaard et al., 2007) and their efficiency and cost effectiveness on a watershed scale remains to be investigated (King et al., 2008). Although conservation practices have beneficial effects, there are studies with contradictory results and they are also not investigated for long-term benefits (Lowrance et al., 1984; Dillaha et al., 1989; Schmitt et al., 1999). Conservation practices designed to reduce runoff problems in the South Fork Iowa River Watershed in Iowa have had no effect on nitrate losses (Karlen et al., 2008). No-till cropping systems in the Salt River/Mark Twain Reservoir watershed in Missouri have not reduced runoff as expected because of the existence of the highly restrictive claypan (Karlen et al., 2008). 
In order to assess the benefits of conservation practices implemented under the 2002 Farm Bill, the Conservation Effects Assessment Project (CEAP) was established in 2003 by the National Resources Conservation Service (NRCS) and Agricultural Research Service (ARS) of the U.S. Department of Agriculture. One of the primary objectives was the Watershed Assessment Study (WAS) to quantify the benefits of conservation practices on water quality (Ghidey et al., 2007).

\section{Agroforestry Practices and Conservation Buffers}

Agroforestry is defined as an "intensive land management practice that optimizes the benefits (physical, biological, ecological, economic, and social) arising from biophysical interactions created when trees and/or shrubs are deliberately combined with crops and/or livestock" (Garrett et al., 1994). The agroforestry practices in the U.S. and Canada are classified into five different categories by the Association for Temperate Agroforestry (Mervin, 1997); namely, riparian and upland buffers, windbreaks, alley cropping, silvopasture, and forest farming (Gold and Garrett, 2009). Riparian and upland buffers are strips of permanent trees, shrubs, and grasses that are planted and managed together with the crop to reduce runoff and NPSP (Dillaha et al., 1989) and provide harvestable products. Riparian buffers are established between crop/pasture land, and aquatic environments to stabilize stream banks, and improve aquatic and terrestrial habitats. Upland buffers are established within the crop land along contours to reduce slope length and steepness, improve internal drainage, enhance infiltration, and create wildlife habitat and connective travel corridors (Udawatta et al., 2002, 2006, 2011; Gold et al., 2009). Windbreaks are tree and shrub barriers planted to reduce wind 
speed. Windbreaks established for livestock reduce animal stress and mortality, feed and water consumption, and odor (Gold et al., 2009). Alley cropping is accomplished by planting single or multiple tree rows with agricultural or horticultural crops cultivated in the alleyways between trees. In silvopasture practices, trees are planted within pasture land or forests are thinned to improve forage area. This practice benefits livestock by reducing temperature stresses, feed, and water consumption. Trees provide high valued lumber optimizing economic returns from the land (Gold et al., 2009). Forest farming involves intentional cultivation under the protected forest cover with special industrial value plants used for medicinal, botanical or decorative purposes (Gold et al., 2009). Grass waterways are also permanent grass vegetation established in the channel to convey the channelized runoff at non-erosive velocities from the fields to the watershed outlet (USDA/NRCS, 2007). Grass waterways are more effective in reducing runoff velocities and sediment concentrations than filter strips in concentrated flows (Dillaha et al., 1986).

Agroforestry buffers differ from vegetative or grassed filter strips in that they consist of a viable forest ecosystem (Schultz et al., 2009). Inclusion of trees in buffers found to reduce shallow groundwater flow through increased transpiration even in a temperate climate (Komor and Magner, 1996; Tomer et al., 2009)). Trees in buffers increase infiltration through preferential flow pathways of old roots and reduce shallow groundwater flow through, increased transpiration (Komor and Magner, 1996; Wagner and Bretschko, 2003). However, measures should be taken to minimize adverse effects on crop yields at the tree-crop interface by tree root competition (Senaviratne et al., 
2012). On the other hand trees could provide high valued lumber to optimize economic returns from the land lost to buffers (Gold et al., 2009). Riparian forest buffers which were established adjacent to water bodies have successfully intercepted runoff and filtered sediments and nutrients (Schultz et al., 2004). Many field studies have illustrated that agroforestry buffers reduce sediment and nutrient yields from crop land (Lowrance et al., 1984; Dillaha et al., 1989; Robinson et al., 1996; Schmitt et al., 1999; Udawatta et al., 2002, 2011; Helmers et al., 2005).

Despite decades of interest, application of agroforestry has been limited in the U.S. due to many factors such as, lack of infrastructural support for research, education and development, difficulty of changing a well established agriculture and forest industry, inherent non-conducive temperate environment for fast tree growth, and lack of established methodologies to apply for specific needs of different ecosystems (Lassoie et al., 2009). The long-term empirical benefits of agroforestry are lacking due to the temporal and spatial complexity of agroforestry systems and soil resource dynamics.

\section{Efficiency of Buffers}

Vegetation in the buffers especially grasses act as barriers to surface runoff and filter sediments and nutrients by improved infiltration and reduced flow volume and flow velocity (Borin et al., 2005). Buffering effects related to watersheds can be defined as responses of a specific landscape structure to the incoming flows of a given material (Viaud et al., 2004). The buffering response can be either reductions in pollutant 
loadings or attenuation of temporal dynamics of pollutants traveling through the buffers. The effect of buffers also can be expressed as trapping efficiency: the difference between the material, incoming and outgoing, divided by the incoming amount (Dosskey et al., 2008). The effect of buffers of a given width strongly depends on the material being trapped especially the size of the soil particles (Dosskey et al., 2008; Lui et al., 2008). The buffering effect of vegetative buffers results from a combination of processes initiated by a rainfall-runoff event and the result of interactions of the hydrological properties of the drainage area and the buffer zone (Helmers et al., 2008).

Dorioz et al. (2006) has presented a schematic representation of a functioning grass buffer (Fig. 2.1). The rough and porous surface of buffers slows down the advancing runoff water, causing it to infiltrate into the soil. The partitioning of water between infiltration and runoff at the surface of the buffer depends on soil characteristics, incoming flow rate, and the duration of the event. During the course of continuous runoff events, infiltration tends to get slower as the soil becomes saturated and with gradual silt-up (Barfield et al., 1979; Hayes et al., 1979). Effectiveness of buffers depends on rainfall intensity, frequency and antecedent moisture content. Accordingly, the infiltrated fraction of runoff may be stored in the soil (Compartment 3, Fig. 2.1) or slowly deep percolated. 


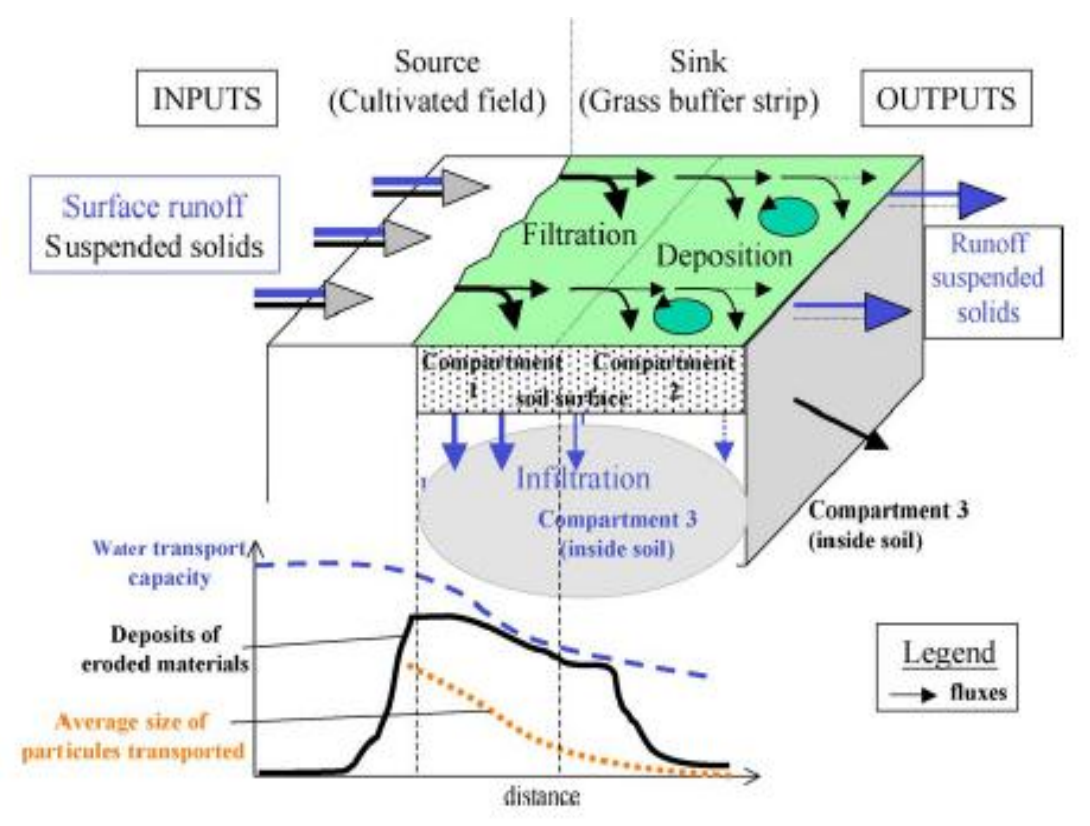

Fig. 2.1. Schematic diagram of functions of a buffer strip (Dorioz et al., 2006).

When the soils in the buffers are saturated before the runoff event such as during frequent rainfall events with high intensity, the infiltration rate becomes very low and buffer strips tend to be ineffective in sediment reduction (Lui et al., 2008).

The rougher the buffer surface, the slower are the forces that carry the solid particles in water causing them to sediment randomly and become trapped (MunosCarpena et al., 1999). According to Dorioz et al. (2006), coarser sediments are usually deposited at the front edge of the grass buffer strip (compartment 1, Fig. 2.1) and also accumulate in the final meter of the source field. A study by Pearce et al. (1997), found that the majority of the sediment retained is deposited up-gradient of the small grass buffer strip (0.3-1 m), in small piles elongated in the direction of flow. Studies have found that much of these accumulated sediments particles were greater than $20 \mu \mathrm{m}$ in 
size (Neibling and Alberts, 1979) and were in the form of stable micro-aggregates (Dorioz et al., 2006). Gharabaghi et al. (2006) found that almost all easily removable particles larger than 40 microns in diameter were captured within the first few meters of the buffer strip. The remaining smaller particles needed more time and low energy level to settle and the only mechanism that helped the removal of them was infiltration. However, Dorioz et al. (2006) suggested that finer clay particles require a different process of filtration which is caused by the turbulence created by the myriad of surfaces associated with the vegetation. Unlike in a typical filtration where particles are trapped in front of smaller pores than the size of the particle, in the turbulence filtration, turbulent flow circulates through the leafy matrix of grass buffers causing a microcentrifugation effect on finer particles (Dorioz et al., 2006). The same authors explain that this process is prevalent further down in the buffer strip (compartment 2, Fig. 2.1). Hence the authors suggest a granulometric sorting, (first the coarser ones, then the finer ones) occur while solid material passes through the buffer along with progressive declining of transport capacity of solids with water. Retention of coarser fractions is more common (Hayes et al., 1984; Robinson et al., 1996) than finer fractions in many cases as the latter is constrained by its specific requirement for a favorable flow regime for turbulent filtration.

\section{Factors Affecting Buffer Efficiency}

\section{Width of buffers}

The width of the buffer is considered one of the most important factors to attenuate sediment and nutrients and improve stream water quality by riparian buffers 
(Vidon and Hill, 2004). Conversely, if the width is too great, it will reduce land under agricultural use, preventing farmers' interest in cooperating with environmental preservation efforts. The optimum width depends on a wide range of variables governing the efficacy of vegetative buffers but should be wide enough to trap fine clay particles. Studies have found that the percentage of pollutants that are retained increases more slowly as the width is increased (Dillaha et al., 1989; Magette et al., 1989; Robinson et al., 1996; Schmitt et al., 1999). Studies also indicate that increasing buffer width beyond four to seven meters produces only marginal increases in terms of NPSP removal in runoff (Robinson et al., 1996; Schmitt et al., 1999). With low to moderate flow rates, $20-\mathrm{m}$ wide filter strips have been able to remove $90 \%$ of the sediments due to enhances in infiltration of fine sediments with water (Lui et al., 2008). Dosskey et al. (2008) states that the existing body of experimental results on filter strips cannot be collectively used to develop an effective design guide related to the buffer width because of the varying combination of site conditions. They have developed a simple graphical representation to find the optimum width of a buffer using field slope length, slope, soil texture and the Universal Soil Loss Equation (USLE) ‘s C factor.

\section{Slope, slope length, soil texture, and soil structure}

Sediment trapping efficiency of buffers is mainly dependent on the slope of the land as well as the intensity and frequency of rainfall events (Magette et al., 1989). Steeper slope areas would be expected to result in greater loadings to the buffer and reduce trapping efficiencies for a given filter strip width especially in more extreme conditions. Studies have shown that in slopes ranging from 3 to $12 \%$, buffer strips can 
remove 56 to $97 \%$ of sediments depending on the buffer width and the area draining to the buffer strip (Franti, 1997). The efficiency of buffers deteriorates when sheet flows are not maintained, and sediments are allowed to deposit, and form natural berms along the edge of the buffers (Dillaha et al., 1986). Long field lengths yield greater runoff loads and reduce sediment trapping efficiency of a given buffer width than a short field length (Dosskey et al., 2008).

Water infiltration largely depends on soil texture and structure. Infiltration is the main mechanism of removing smaller soil and organic particles $(<40$ microns in diameter; Gharabaghi et al., 2006). Dosskey et al. (2008) stated that slope and soil texture are the most influential site factors that determine how wide a filter strip must be to achieve a target trapping efficiency. Each of these site characteristics can have large individual effects. According to their findings, a $4 \mathrm{~m}$ (13.1 ft) wide strip on a $2 \%$ slope would trap nearly $100 \%$ of sediment in runoff if the soil was sandy loam but only $35 \%$ of sediment in runoff if the soil was silty clay loam. The finer-textured soils like silty clay loam allow less infiltration in the field and in the buffer strip and produce more fine particles that are less easily retained in a filter strip. On the other hand a 20-m wide strip on a silty clay loam having a $2 \%$ slope would trap $85 \%$ of incoming sediment, but only $20 \%$ of incoming sediment if the slope was $10 \%$. The same authors reveal that a filter strip on a coarse-textured soil below a disk plowed corn field (USLE C factor $=0.50$ ) yielded substantially higher trapping efficiencies for sediment and water than an otherwise similar strip on fine-textured soil below a chisel-tilled corn field (USLE C factor $=0.15)$. Therefore, larger slopes, finer textured soils, and low cover management 
increase field runoff leading to reductions in the trapping efficiencies of the filter strips (Phillips, 1989; Helmers et al., 2005; Dosskey et al., 2008).

\section{Pollutant type}

For a given buffer width, the trapping efficiency for sediments was higher than that for water under the same site conditions (Dosskey et al., 2008). This illustrates that infiltration capacities of buffer strips often become inadequate to infiltrate all runoff water that results from rainfall. Most of the dissolved pollutants such as nitrate, atrazine, and dissolved phosphorus can be approximated using the extent of water infiltrated, as this is also the mechanism of solute retention. However, Schmitt et al. (1999) showed that water infiltration in filter strips can underestimate dissolved pollutant retention by up to $16 \%$ in a field experiment. Some studies have stated that remobilization of previously trapped pollutants during subsequent runoff events offset the underestimation of dissolved pollutants by water (Dillaha et al., 1989; Lee et al., 2000). On the other hand sediment retention cannot be used to estimate sediment-bound pollutants such as $\mathrm{P}$ as they tend to be associated more with finer particles, such as clays and fine silts, which do not deposit as readily in the filter strips as sands and coarse silts and therefore are somewhat less represented in sediment as a whole (Schmitt et al., 1999; Lee et al., 2000). A tilled field study has shown that the retention of $\mathrm{P}$ is about $10 \%$ less than sediments despite P being mainly in sediment-bound form (Dillaha et al., 1989; Schmitt et al., 1999). A small fraction of $\mathrm{P}$ is also in the dissolved form and it further lowers its retention in buffers (Dillaha et al. 1989; Schmitt et al. 1999). These scientists suggest that the dissolved pollutants require much wider filter strips than with 
sediment to achieve the same level of trapping efficiency.

\section{Ratio of buffer area to source area}

Low ratio of buffer to source area leads to greater sediment loads and lower trapping efficiencies of buffers (Liu et al., 2008). The USDA-Natural Resources Conservation Service (NRCS) has set standards for buffer area to source area ratios based on the USLE R factor (rainfall amount and intensity). Accordingly, the ratio of filter strip area to the source area should be greater than 1:70 in regions with USLE R factor values between zero and 35; 1:60 in regions with $\mathrm{R}$ factor values between 35 and 175; and 1:50 in regions with $\mathrm{R}$ factor values more than 175 (Liu et al., 2008).

\section{Type of vegetation}

The surface roughness is governed mainly by the vegetative cover of soils. The presence of dense plant cover also increases infiltration due to the dense root system of the surface layers (Magette et al., 1989; Rose et al., 2003). Inclusion of trees in buffers effectively increase infiltration capacity through preferential flow pathways created by old roots and reduce shallow groundwater flow through increased transpiration (Komor and Magner, 1996; Wagner and Bretschko, 2003; Kumar et al., 2012). Udawatta et al. (2008a) found that vegetative filter strips containing grass and trees after ten years of establishment increased water soluble aggregates as a result of high microbial activity indicated by elevated soil carbon, soil nitrogen, and enzyme activity. Another study using high-resolution x-ray computed tomography (CT) on the same site showed increased porosity in soils of the grass and agroforestry buffers (Udawatta and Anderson, 2008b). The improved soil aggregation, structure and porosity by the buffer 
vegetation have contributed to high infiltration rates and high trapping efficiencies of buffers (Kumar et al., 2012).

\section{Height of vegetation}

Another important factor is the relative height of vegetation in the buffers to the runoff water depth. When the depth of water flow is greater than the height of vegetation, the orientation of vegetation becomes parallel to the flow increasing the flow rate and reducing the sediment filtration. Therefore, the use of stiff-stemmed grasses such as switch grass (Panicum virgatum) with fescue (Festuca) for filter strips has been suggested to improve the effectiveness of buffers (Blanco-Canqui et al., 2004).

\section{Placement and shape of buffers}

In-order to mitigate the NPSP care should be taken to design buffer systems to place them in critical source areas (areas where the potential of pollutants meeting the transport mechanism is high), such that interaction of surface and ground water with buffer systems is maximized. The importance of placing the buffers where they have the greatest impact on water quality has been discussed in the literature for a considerable period of time. Tomer et al. (2009) emphasized the importance of developing a method to prioritize locations for buffer establishment using publicly available data across broad areas. One such technique uses slope, soil texture, and soil erodibility from the U.S. Department of Agriculture's National Soil Survey as key soil attributes to rank each soil type for the capacity of buffer identified for it to trap sediments. The other method namely the digital terrain technique uses digital elevation models to analyze and determine the range of landform parameters to create maps which 
reveal pathways of water movement and areas of water accumulation on the landscape. The wetness index $(\mathrm{WI})$ is calculated as $\mathrm{WI}=\ln (\mathrm{As} / \tan \beta)$, where, As is the specific

catchment area $\left(\mathrm{m}^{2} \mathrm{~m}^{-1}\right)$, and $\beta$ is the slope angle (degrees). The wetness index is used to map areas most prone to soil saturation during rainfall events (Tomer et al., 2009).

Larger WI values are associated with flat areas with larger upslope contributing areas and buffers in these areas can remove contaminants from shallow ground water and/or filter surface runoff (Tomer et al., 2009). However, in certain instances when shallow ground water nears the surface surface infiltration may not occur.

Measures such as irregular shaped buffers designed to intercept and transport water based on the potential loads from critical source areas may have greater water quality benefit than just uniform width buffers (Dosskey et al., 2002). The main purpose of such practice is to maximize the time of contact with buffers, enhance efficient flow distribution, or intercept flow prior to concentration. However, use of farm machinery should not be obstructed by any irregular shaped buffers otherwise farmer acceptance will be poor.

\section{Problems encountered with buffers}

The buffer strips work best when overland flow is shallow and uniform along the buffer (Barfield et al., 1979). Though most of the research assumes that the flow of runoff is uniform through the buffers, a study by Dillaha et al. (1989) found that the majority of buffers constructed by landowners under the Conservation Reserve Program were ineffective as sheet flow was not maintained and concentrated flow was entering 
the edge-of-field buffers. This field reality was attributed to the formation of natural berms along the edges of the field from deposition of sediments and leading to the creation of concentrated flows.

Parajuli et al. (2008) highlighted the importance of quantifying and evaluating the effects of best management practices (BMPs) for maximizing the effectiveness of BMPs for minimizing pollutants. The long-term empirical benefits of agroforestry are lacking due to the temporal and spatial complexity of agroforestry systems and soil resource dynamics. It is also important to evaluate how these benefits vary in the longrun to determine their impact on water quality and crop productivity. Conducting experiments in watersheds may not be feasible due to their complex and large scale nature, high costs involved in monitoring, private ownership of land, and significant time needed for results which may be too late to avoid any negative consequences of current practices.

\section{Hydrologic Models}

Numerous models have been used to predict watershed hydrology, which may be broadly categorized as data-driven stochastic models and process driven physically based models (Beven and Binley, 1992; Singh and Frevert, 2006; Lohani et al., 2010; Pechlivanidis et al., 2011). Stochastic models estimate model parameters using mathematical or statistical techniques based on historical records from past events. Stochastic models require large amount of data to build the model but need less amount of data to run the model (Lohani et al., 2010). Stochastic methods range from simple 
linear regression models to complex non-linear real time dynamic models such as models using artificial intelligence techniques. Stochastic models can incorporate uncertainty and sometimes include real time recursive updating of model parameters based on data. However, they are not transferable or applicable widely due to the biasness of data with which the models were built.

The physically based approach is using scientific knowledge of physical forces, processes, and their mathematical representations to build the models. Physically based models, also called deterministic models, try to represent physical processes observed in the real world (Sen, 2009). Some instances of such models are those representing surface runoff, subsurface flow, evapo-transpiration, and channel flow. Flow and transport processes are sometimes derived using differential equations (for example, unsaturated flow by Richard's equation or using empirical equations). Empirical equations are fitted equations using experimental results. e.g. NRCS curve number in runoff estimation. A physically based model has a theoretical basis and it's parameters and variables are measurable in the field (Beven and Binley, 1992), where as stochastic model data representation has no real theoretical basis (King et al., 1999). Physically based hydrological models need large amount of spatial information on natural parameters such as geology, land use, soils, and management to build and run the model. Even though physically based models are complex and require large amounts of data they are more transferable than regression and stochastic models since they are based on physics (Blasone et al., 2008). However, physically based models require an integrated view of real world hydrological processes and their interactions for their proper use. 
The use of physically based distributed hydrological models has become increasingly common in simulating complex watersheds to find solutions to a range of environmental problems (Reginato and Piechota, 2004; Singh and Frevert, 2006; Blasone et al., 2008). Physically based models offer an efficient tool to simulate potential changes in landscapes and land management practices to understand their impact on NPSP, especially when long-term experiments to monitor such effects within large watersheds become overly expensive (Mulla et al., 2005; Tuppad et al., 2009).

The first ever watershed model was the Stanford Watershed Model (SWM; Crawford and Linsley, 1966) created in the early 1960s with the introduction of continuous hydrologic modeling to civil engineers who were engaged in flood forecasting, stream water management and other related water resource planning (Donigian and Imhoff, 2006). The birth of environmental consciousness in the 1970s with the first Earth Day commemoration and the formation of the USEPA created another period of model interest; the SWM was expanded and refined to create Hydrocomp Simulation Program (HSP) which is facilitated with general nonpoint source loading and water quality simulation capabilities (Donigian and Imhoff, 2006). The Clean Water Act of 1975, which made both point and nonpoint source assessments mandatory, helped the USEPA to feel the necessity for advanced models which can simulate complex watersheds with combined processes. With the advancement of computing power and memory in the 1980s, several physically based models were developed for NPSP studies for watersheds such as, Chemicals, Runoff and Erosion from Agricultural Management Systems (CREAMS; Knisel, 1980), Groundwater 
Loading Effects of Agricultural Management Systems (GLEAMS; Leonard et al., 1987), AGricultural Non-Point Source (AGNPS; Young et al., 1987), Areal Non-point Source Watershed Environment Response Simulation (ANSWERS; Beasley et al., 1980) and Soil and Water Assessment Tool (SWAT; Arnold et al., 1998). Most of these models were developed to evaluate different land-use and management practices on NPSP reductions at the watershed scale.

\section{Agricultural Policy Environmental eXtender (APEX) Model}

Extensive model development for hydrologic and environmental applications has been undertaken by the U.S. Department of Agriculture-Agricultural Research Service; Texas A\&M University, and Texas AgriLIFE Research Units located in Temple, Texas; the Grassland, Soil and Water Research Laboratory (GSWRL); and the Black Lands Research and Extension Center (Gassman et al., 2010). One of the most extensively used models developed by this center was the Soil and Water Assessment Tool (SWAT) which has gained worldwide popularity for analyzing a variety of environmental problems (Gassman et al., 2007). Most of these model developments were for addressing problems of water quality and other environmental issues at the watershed scale. The need for a model to simulate complex combinations of landscapes, cropping systems, and management practices with extensive livestock production at the farm level or small watershed scale gave rise to the development of the APEX model (Williams et al., 1998).

The distributed, continuous, daily time-step APEX model (Williams and 
Izaurralde, 2006) was developed to simulate whole farms at the small watershed scale by extending the single field model, the Environmental Policy Integrated Climate (EPIC; Williams, 1995). The APEX model integrates EPIC components taken from Chemicals, Runoff and Erosion from Agricultural Management Systems (Knisel, 1980) and Groundwater Loading Effects of Agricultural Management Systems (Leonard et al., 1987). The APEX model has added features to simulate flow and route sediment and nutrients between multiple fields, called "subareas" and "channel systems," to the watershed outlet. This feature of APEX is one of the most comprehensive approaches available in current landscape-scale models (Srivastava et al., 2007). The APEX model can also simulate novel management strategies such as filter strips in upland crop fields, vegetated grass waterways, intensive rotational grazing, and land application of manure from feedlots or waste storage ponds to evaluate their impacts on pollutant loadings (Gassman et al., 2009). The APEX model has been selected for national-scale studies to evaluate the effectiveness of vegetative filter strips (Arnold et al., 1998) and to find the benefits of the conservation programs of the United States Department of AgricultureNatural Resources Conservation Service (USDA/NRCS) by the Conservation Effects Assessment Project (Williams et al., 2010).

The user interface of the APEX model has undergone rapid progression over the past few years from the DOS-based version to the Windows-based WinAPEX and to the GIS-based ArcAPEX (Gassman et al., 2010). ArcAPEX, also facilitates for direct integration with the SWAT model created with ArcSWAT. Common consistency of the two models' input/output parameters enables scaling up the ecosystem benefits of small 
scale watershed studies to larger watersheds in order to make long-term predictions on the benefits of best management practices (BMP; Tuppad et al., 2009). The scaling up from controlled area research results (i.e. plot or field) to mixed-use watersheds and then to larger scale watersheds is a challenging process in watershed assessment studies (Ghidey et al., 2007: Tuppad et al., 2009). This feature allows multiple scale simulations to be incorporated within a watershed scale model. In ArcAPEX, APEX can be deployed for modeling of more detailed small sub-watersheds with complex agronomic systems, whereas SWAT can be implemented for modeling larger subwatersheds with simple agricultural or nonagricultural landscapes while integrating contributions from all sub-watersheds (Tuppad et al., 2009).

\section{APEX Model Components}

\section{Subarea components}

APEX allows the watershed to be subdivided as much as necessary to smaller units called subareas to ensure each unit is homogenous in soil, land use, management, etc. (Williams et al., 2006). Spatially distributed functions of APEX simulate key landscape processes such as routing water sediments, nutrients and pesticides across these hydrologically connected landscape subarea units (Wang et al., 2012). It also simulates interactions between subareas involving surface runoff, return flow, sediment deposition and degradation, nutrient transport, and groundwater flow (Williams et al., 2006). Each subarea component is simulated for weather, hydrology, erosion-sedimentation, nutrients, pesticide fate, plant growth, soil temperature, tillage, economics, and plant environment control (Wang et al., 2012). 


\section{Runoff}

The subarea hydrology component simulates surface runoff, peak runoff rate, potential evapotranspiration and available soil water capacity. The APEX uses two methods to simulate surface runoff volume based on daily rainfall amount: a modification (Williams, 1995) of the Soil Conservation Service (SCS) curve number technique (USDA/NRCS, 2004), and the Green and Ampt infiltration equation (Green and Ampt, 1911). The modification of the SCS curve number method (USDA/NRCS, 2004) which as been found to be reliable and been used for many years in the U.S., is computationally efficient, uses readily available daily rainfall data, and takes into account soil type, land-use, and management practices to estimate runoff (Williams et al., 2006). However, it does not take into account the rainfall intensity and only predicts daily runoff. The Green and Ampt method is offered as an option which incorporates rainfall intensity and also calculates runoff at shorter intervals. The APEX model also offers two options for estimating the peak runoff rate: the modified Rational formula (Williams, 1995), and the SCS TR-55 method (USDA/NRCS, 1986). The modified Rational method (Williams, 1995) includes a stochastic element in the rational equation to allow realistic simulation of peak runoff rates from daily rainfall and monthly rainfall intensity.

Subsurface flow is simulated as simultaneous processes of horizontal and vertical flow by the APEX model using storage routing and pipe flow equations (Wang et al., 2012). The vertical flow contributes to the ground water storage which in turn is subjected to deep percolation or return flow. Horizontal flow consists of lateral flow 
which enters the subarea (soil water storage) immediately below and quick return flow which enters the subarea channel. Once the soil layer water content exceeds the field capacity, water is routed to the next layer based on saturated conductivity until it has drained to field capacity. This storage routing technique is applied layer by layer from the surface to the deepest layer. If the saturated conductivity of lower layers becomes very slow like in claypan soils, excess water is transferred to the layer above when the lower layer water content has reached field capacity. This approach allows simulation of hydrology in claypan soils.

\section{Evapotranspiration}

Five options were provided by the model for estimating potential evaporation: Hargreaves and Samani (1985), Penman (1948), Priestley and Taylor, 1972), Penman-Monteith (Monteith, 1965), and Baier and Robertson (1965). The Hargreaves and Samani (1985) method was found to be as efficient as the Penman method for predicting potential evaporation just using radiation and air temperature (Oudin et al., 2005), whereas the Penman method requires wind speed and relative humidity data in addition to radiation and air temperature. The model simulates soil and plant evaporation separately (Williams et al., 2006).

\section{Erosion}

The APEX model simulates erosion caused by rainfall (or irrigation) using seven equations: the Universal Soil Loss Equation (USLE; Wischmeier and Smith, 1978), the Onstad-Foster modification of the USLE (Onstard and Foster, 1975), the Modified Universal Soil Loss Equation (MUSLE; Williams, 1975), two variations of MUSLE 
(Williams, 1995), a MUSLE structure that accepts input coefficients, and the Rational Universal Soil Loss Equation (RUSLE; Renard et al., 1997). The MUSS equation (Williams, 1995), is a modification of MUSLE for small watersheds. The USLE and RUSLE use rainfall as the driving force of erosion whereas the MUSLE and its variants use runoff as the driving force (Williams et al., 2006). Use of the runoff variable in MUSLE rather than rainfall has increased the accuracy of estimated erosion and sediment loss (Williams et al., 2006). The USLE equation estimates annual yield of sediment. The Onstad-Foster equation combines energy factors used in the USLE and MUSLE. The RUSLE consist of improved methods for estimating the crop cover factor and the slope length factor especially for steep slopes (Williams et al., 2006).

\section{Cropping systems and crop yield}

APEX is facilitated with multi-cropping algorithms and could be used for agroforestry systems with inter-crop trees, crops, and vegetables (Tuppad et al., 2009). The plant competition algorithm incorporated in APEX accounts for competition between multiple crops, and weeds for light, water, and nutrients. However, Tuppad et al. (2009) suggest that plant parameters needed to be expanded in the data set before applying it to agroforestry systems. Crop growth is simulated based on the temperature from planting date to harvest date or until accumulated heat units (growing degree days) equal the potential heat units (PHU) for the crop (Williams, 1995). The chain of processes simulated during crop growth are leaf interception of solar radiation; conversion to biomass; division of biomass into roots, above-ground mass, and economic yield; root growth; water use; and nutrient uptake (Williams, 1995). The 
actual growth is calculated by the difference of potential growth and growth reductions due to stresses in temperature, solar radiation, soil moisture, soil aeration, labile $\mathrm{N}$ and

$\mathrm{P}$, and soil strength. The yield component of APEX is derived from the EPIC model and it has been tested widely to predict yield with reasonable accuracy (Gassman et al., 2005).

\section{Studies with APEX Model}

Flowers et al. (1996) used the APEX model to simulate eight plot scale studies having crops with different treatments of dairy manure and crop/filter strip combinations with hay production operations (with limited grazing) which were monitored for cumulative runoff, sediment, and nutrients for 17 months. They found that the calibrated APEX model predicted overall cumulative runoff, sediment and nutrients very similar to the observed values. Gassman (1997) used the APEX model within an integrated modeling system for U.S. National Policy environmental baseline simulations of the Upper North Bosque River watershed, Texas. This study and subsequent scenario analyses found that the non-calibrated APEX predictions were clearly sensitive to management practices of dairy cow manure applications (Osei et al., 2000; Gassman et al., 2005). An APEX simulation study with different manure application methods of a field with double cropped sorghum (Sorghum bicolor (L.) Moench,) and winter wheat (Triticum hybernum), found that incorporation of manure with a tandem disk resulted in $37 \%$ reduction in total $\mathrm{P}$ loss as compared with simulated surface manure applications (Osei et al. 2003). Most of the early studies using APEX were focused on NPSP resulting from livestock waste applications (Gassman et al., 
2005).

Intarapapong and Hite (2003) evaluated economic and environmental impacts of cropping systems with the edge of the field filter strips on crop yield, runoff, sediment and nitrate loadings using the APEX model. Harman et al. (2004) evaluated alternative runoff control practices for atrazine use in a corn and sorghum watershed using the APEX model. They found sediment ponds, grass filter strips, band application, and construction of wetlands as most the effective practices to reduce atrazine losses. Saleh et al. (2004) used the APEX version for forestry conditions to simulate annual flow, sediment, $\mathrm{NO}_{3}-\mathrm{N}$, organic $\mathrm{N}$, total $\mathrm{N}, \mathrm{PO}_{4}-\mathrm{P}$, organic $\mathrm{P}$, and total $\mathrm{P}$ losses from nine small (2.6 to 2.7 ha) watersheds. The following treatments were compared: clearing, shearing, windrowing, clear cutting, roller chopping, and burning. They reported that APEX reasonably calibrated with measured data and was able to predict discharges satisfactorily for the forest conditions which were one or two orders less than the agricultural watersheds. Williams et al. (2006) used, non-calibrated, but a validated APEX model to simulate edge of the field vegetative filter strips to see their effects on annual losses of nutrients from feedlots and manure application fields in Texas and Carrington, North Dakota. They investigated the effects of edge of the field vegetative filter strips with various dimensions by model simulations. Results showed that the feedlots with lowest slopes, lowest annual rainfall, and filter strips with $100 \%$ filter flow length:feedlot flow length ratios had the maximum reduction of annual organic and soluble nitrogen and phosphorus losses. The reductions in runoff were not reported. Gassman et al. (2006) evaluated different cropping systems and tillage practices in the 
larger Maquoketa River watershed which consisted of a mixed land use of livestock and corn-soybean rotation with the APEX model; they found $r^{2}$ values of 0.7 for average monthly tile flow. Wang et al. (2007) tested nine small forested watersheds for clear-cut harvesting and mechanical site preparation on flow and sediment loadings using the APEX model. They reported coefficient of determination $\left(r^{2}\right)$ values larger than 0.5 and Nash Sutcliff coefficient (NSC; Nash and Sutcliffe, 1970) values larger than 0.4 for the monthly runoff from the watersheds. Wang et al. (2008) used the calibrated and validated APEX model for monthly runoff (with $r^{2}$ and NSC values $>0.6$ ) to simulate and compare ridge-till and conventional tillage systems. The APEX simulation of two small watersheds at the USDA Deep Loess Research station near Treynor, Iowa showed $\pm 5 \%$ and $\pm 6 \%$ error between the predicted and observed mean monthly surface runoff and sediment yield during the calibration and the validation period, respectively (Wang et al., 2008). Mudgal et al. (2008) reported $r^{2}$ and NSC values greater than 0.5 and 0.42 , respectively for APEX simulations of event runoff for plot treatments of different cropping systems: mulch tillage corn/soybean rotation, no-till corn/soybean rotation, and no-till corn/soybean/wheat rotation. The study used APEX to model atrazine losses on 14 different research plots located in the Missouri Goodwater Creek watershed and found that the model satisfactorily predicted the measured surface runoff and atrazine losses.

Tuppad et al. (2009) used the new ArcGIS based ArcAPEX to simulate contour farming, no-till cropping, and furrow diking to evaluate their effects on NPSP. Their results indicated the need for further refinement of ArcAPEX to improve the validation 
accuracy. Yin et al. (2009) calibrated the APEX model for event-runoff from a three plot study with different types of trees and tree/pasture combinations. They reported $r^{2}$ and NSC values between 0.55 to 0.85 and 0.41 to 0.84 , respectively. APEX has predicted daily runoff and sediment yield with $r^{2}$ values between 0.6 to 0.8 and NSC values between 0.58 to 0.77 for the Shoal Creek watershed with over $22.5 \mathrm{~km}^{2}$ area within the Fort Hood military reservation in central Texas (Wang et al., 2009). Longterm simulations of BMPs: pasture planting, nutrient management, brush management, clearing and range planting, prescribed grazing, critical area planting, conservation cropping, contour farming, terraces, ponds, grade stabilization structures, and waterways using the APEX model at field and watershed levels were reported by Tuppad et al. (2010). The model predicted average annual field level reductions by these BMPs as $35 \%$ in runoff, $83 \%$ in sediment, $72 \%$ in $\mathrm{TN}$, and $58 \%$ in TP. The reductions at the subwatershed outlets, ranged from $2.9 \%$ to $6.5 \%$ in runoff, $6.3 \%$ to $14.8 \%$ in sediment, $11 \%$ to $15.1 \%$ in $\mathrm{TN}$, and $6.3 \%$ to $8.6 \%$ in TP. Kumar et al. (2011) calibrated and validated the APEX model for event-runoff from small pasture watersheds with edge of the field agroforestry buffers with $r^{2}$ and NSC values over 0.5. Mudgal et al. (2012) used a calibrated and validated APEX model for event-based runoff $\left(r^{2}\right.$ values around 0.8 and NSC values around 0.7) simulation for edge of field filter strips located in the critical management areas of a 35-ha field with a corn-soybean rotation. Cavero et al. (2012) used the APEX model to assess the different irrigation management on $\mathrm{N}$ loads of irrigated watersheds in Turkey, Spain and Algeria. They found annual model predictions more accurate than the monthly predictions and irrigation management was the key to 
reduce off-site N loads. Reviews of Gassman et al. (2010) and Wang et al. (2012) give further updates on recent developments and applications of the APEX model. The theoretical and technical details of the APEX model can be found in Williams and Izaurralde (2009) and Williams et al. (2008).

\section{Sensitivity Analysis}

It is nearly impossible to build a model to represent exact real world conditions. Since models are an approximation of reality and based on many assumptions of input data, the inherent uncertainty of it will be depicted in the predictions as well (Heuvelink, 1998). Physically based models rely on mathematical equations on mass, momentum and energy conservation applied in a spatially distributed model domain, and parameter values that are derived from catchment characteristics. The sensitivity analysis of model parameters, provides useful tools for calibration as well as allow the model to be transferable to different watersheds (Francos et al., 2003). The model sensitivity analysis determines the rate of change in model output with respect to the changes in model inputs (Moriasi et al., 2007). Crosetto et al. (2000) suggested that sensitivity analysis is a prerequisite for model building. Wang et al. (2005) compared variancebased sensitivity analysis and the Morris measure for parameter sensitivity analysis with the APEX model. The variance-based sensitivity analysis estimates the fractional contribution of each parameter to the total variance of the model output while the Morris measure calculates the total and interaction effects. Though the variance-based analysis was found to be very reliable, its high computational cost has encouraged selection of the enhanced version of the Morris method which produced reasonable results for a 
national assessment project, Conservation Effects Assessment Project (CEAP).

\section{Global Optimization Methods for Parameter Calibration}

Model calibration and validation is the process of demonstrating the ability of a model to simulate watersheds with sufficient accuracy (Moriasi et al., 2007). Owing to the limitations in measurement and issues related to scale, hydrological models often contain parameters that cannot be measured directly and need to be estimated through an inverse method by calibration so that observed and predicted output values are in agreement (Beven, 2001). Refsgaard (1997) suggested that parameter values should be justified by field data as much as possible and limit the parameter space to simplify the calibration process. The sensitivity analysis helps to identify the non-responsive parameters which can be fixed to their prior values and thus reduce the number of parameters for calibration (Muleta and Nicklow, 2005). However, data requirements are often obstacles for a proper validation especially, availability of all the variables are rare. Due to this reason, most distributed models have usually been calibrated and validated only against discharge data (McMichael et al., 2006; Engeland et al., 2006). During the calibration of the model, one or more objectives are used as model performance indicators $\left(r^{2}\right.$ and NSC) to measure the agreement between the observed and simulated values. Prior to the advent of high speed computers, the parameter adjustments of the model were made through a manual trial and error procedure utilizing knowledge of the watershed and experience of the hydrologists (Gupta et al., 1999). This method of calibration is subjective and labor intensive. Recently, automated calibration methods, which are multi-objective and relatively easy 
to implement with high speed computers, have become more popular (Gupta et al, 1998; 1999; van Griensven et al., 2006; Zhang et al., 2009; Vrugt et al., 2009). Automatic calibration coupled with global optimization algorithms can efficiently and effectively search optimum parameter combinations / solutions to minimize (or maximize) objective functions which measure the agreement between observed and model predictions (Gupta et al., 1998). This kind of optimization is especially advantageous to reduce the number of time consuming runs of sophisticated physically based distributed watershed models (Gupta et al., 1998).

Zangh et al (2009) compared genetic algorithm, shuffled complex evolution, and particle swarm optimization, deferential evolution, and artificial immune system optimization methods for the Soil Water Assessment Tool (SWAT) model. The genetic algorithm produced the best combination of objective values with a large number of model runs, followed by deferential evolution, shuffled complex evolution, particle smarm optimization, and artificial immune system. They suggest that for computationally intensive models, the numbers of model evaluations needed to obtain acceptable objective values are deciding factors on an optimizing algorithm. They further elaborate that an algorithm should be selected which could find acceptable objective values within a limited number of evaluations (less than 1000).

\section{Fuzzy Logic Models}

Fuzzy logic (FL) models are data driven and use the artificial intelligence technique, fuzzy logic. The modern concept of fuzzy sets and fuzzy logic was brought 
forward by Zadeh (1965) as an alternative to classical logic. Though the Western world opposed fuzzy thinking initially as it contradicted Aristotelian or scientific logical thinking, the Eastern world embraced it from the conception and by 1980 Japan had over 100 successful FL devices (Kosko and Isaka, 1993). The FL has many advantages: conceptually easy to understand, follows a natural approach, is flexible, is tolerant to imprecise, and can handle incomplete and vague data; FL which can model complex non-linear functions in a simplified manner (Kosko and Isaka, 1993; Ross, 2004). The main advantage of FL algorithm is its capability to incorporate knowledge in a human like descriptive manner in the form of simple rules (Tayfur et al., 2003). The FL techniques have been used in assessing water quality over the conventional Water Quality Index (WQI) procedure to obtain more accurate results (Chang et al., 2001; Lermontov et al., 2011). The FL model developed by Mitra et al. (1998) predicted soil erosion more accurately with a minimum input dataset in comparison to the USLE model for a large watershed. Fuzzy logic concepts have been successfully used in hydrology to model infiltration and water movement in the unsaturated zone (Bardossy, 1996). The conventional regression equations used to model potential snowmelt runoff for forecasting water supply tended to be less reliable for low runoff years and the FL expert system has been found to forecast water supply equally well in either low or high runoff conditions (Mahabir et al., 2003). Fuzzy logic has been suggested as an important tool in watershed assessment and classification as it does not require extensive quantitative data but can be developed using more qualitative information based on an expert's understanding and historical data (Guertin et al., 2000; Silvert, 2000). Some 
other studies have used fuzzy logic: to estimate solar irradiation from sunshine duration (Sen, 2009), to improve the performance of the Revised Universal Soil Loss Equation (RUSLE; Tran et al., 2002), to map soils (Zhu et al., 2001), to assess water quality (Zhu et al., 2001; Chang et al., 2001), to predict the mean sediment load from bare soil surfaces subjected to rainfall-runoff driven sediment transport (Tayfur et al., 2003), and to forecast water supply (Mahabir et al., 2003). According to Tayfur et al. (2003), a fuzzy model for sediment load prediction was better than physically-based and artificial neural network models with high rainfall intensities and varying slopes.

\section{List of References}

Adeuya, R.K., K.J. Lim, B.A. Engel, and M.A. Thomas. 2005. Modeling the average annual nutrient losses of two watersheds in Indiana using GLEAMS-NAPRA. Trans. ASAE. 48(5): 1739-1749.

Allan, D., D. Erickson, and J. Fay. 2003. The influence of catchment land use on stream integrity across multiple spatial scales. Freshwater Biol. 37(1): 149-161.

Anderson, D.W., P.M. Glibert, and J.M. Burkholder. 2002. Harmful Algal Blooms and Eutrophication Nutrient Sources, Composition, and Consequences. Estuaries 25: 704-726.

Arnold, J.G., R. Srinivasan, R.S. Muttiah, and J.R. Williams. 1998. Large area hydrologic modeling and assessment part I: Model development1. JAWRA 34(1): 73-89.

Baier, W., and G.W. Robertson. 1965. Estimation of latent evaporation from simple weather observations. Canadian J. Plant Sci. 45(3): 276-284.

Bardossy, A. 1996. The use of fuzzy rules for the description of elements of the hydrological cycle. Ecol. Model. 85(1): 59-65.

Barfield, B.J., E.W. Tollner, and J.C. Hayes. 1979. Filtration of sediment by simulated vegetation: Steady state flow and homogenous sediment. Trans. ASAE 22: 540545.

Beasley, D.B., L.F. Huggins, and E.J. Monke. 1980. Beasley, D. B., L. F. Huggins, and 
E. J. Monke. 1980. ANSWERS: A model for watershed planning. Trans. ASAE 23(4): 938-944. Trans. ASAE 23(4): 938-944.

Beven, K.J. 2001. Dalton Medal Lecture: How far can we go in distributed hydrological modelling? Hydrol. Earth. Syst. Sc. 5(1): 1-12.

Beven, K., and A. Binley. 1992. The future of distributed models: model calibration and uncertainty prediction. Hydrol. Process. 6(3): 279-298.

Blanco-Canqui, H., C.J. Gantzer, S.H. Anderson, E.E. Alberts, and F. Ghidey. 2002. Saturated hydraulic conductivity and its impact on simulated runoff for claypan soils. Soil Sci. Soc. Am. J. 66(5): 1596-1602.

Blasone, R.S., H. Madsen, and D. Rosbjerg. 2008. Uncertainty assessment of integrated distributed hydrological models using GLUE with Markov chain Monte Carlo sampling. J. Hydrol. 353(1): 18-32.

Bockman, O.C., O. Kaarstad, O.H. Lie, and I. Richards. 1990. Bockman, O.C., O. Kaarstad, O.H. Lie, and I. Richards. 1990. p. 245. In Agriculture and fertilizers. Agricultural Group, Norsk Hydro a.s. Oslo, Norway. Agricultural Group, Norsk Hydro a.s., Oslo, Norway.

Borin, M., M. Vianello, F. Morari, and G. Zanin. 2005. Effectiveness of buffer strips in removing pollutants in runoff from a cultivated fi eld in North-East Italy. Agric. Ecosyst. Environ. 105: 101-114.

Brussaard, L., P.C. de Ruiter, and G.G. Brown. 2007. Soil biodiversity for agricultural sustainability. Agric. Ecosyst. Environ. 121(3): 233-244.

Burt, T.P., A.L. Heathwaite, and S.T. Thudgill. 1993. Chapters 9-6. p. p. 239-427. In Nitrate: processes, patterns and management. John Wiley and Sons, Chichester, U.K.

Cavero, J., R. Barros, F. Sellam, S. Topcu, D. Isidoro, T. Hartani, A. Lounis, H. Ibrikci, M. Cetin, J.R. Williams, and R. Aragüés. 2012. APEX simulation of best irrigation and $\mathrm{N}$ management strategies for off-site $\mathrm{N}$ pollution control in three Mediterranean irrigated watersheds. Agr. Water Manage. 103: 88-99.

Chang, N.B., H.W. Chen, and S.K. Ning. 2001. Identification of river water quality using the fuzzy synthetic evaluation approach. J. Environ. Manage. 63: 293-305.

Chen, C., R.J. Roseberg, D. Sugar, and J.S. Selker. 2001. Effect of microsprinkler irrigation on pear fruit growth and postharvest quality. HortTechnology 11(1): $56-61$.

Crawford, N.H., and R.K. Linsley. 1966. Digital simulation on hydrology: Stanford 
Watershed Model IV. Stanford University, CA.

Crosetto, M., S. Tarantola, and A. Saltelli. 2000. Sensitivity and uncertainty analysis in spatial modelling based on GIS. Agric. Ecosyst. Environ. 81(1): 71-79.

Daverede, I.C., A.N. Kravchenko, R.G. Hoeft, E.D. Nafziger, D.G. Bullock, J.J. Warren, and L.C. Gonzini. 2003. Phosphorus Runoff. J. Environ. Qual. 32(4): 14361444.

Dillaha, T.A., R.B. Renear, S. Mostaghimi, and D. Lee. 1989. Vegetative filter strips for agricultural nonpoint source pollution control. Trans. ASAE. 32: 513-519.

Donigian, A.S., and J.C. Imhoff. 2006. History and evolution of watershed modeling derived from the Stanford Watershed Model. p. 21 - 45. In Watershed models. V.P. Singh and D.K. Frevert (ed.). CRC Press, Taylor \& Francis Group, Boca Raton, FL.

Dorioz, J.M., D. Wang, J. Poulenard, and D. Trevisan. 2006. The effect of grass buffer strips on phosphorus dynamics - a critical review and synthesis as a basis for application in agricultural landscapes in France. Agric. Ecosyst. Environ. 117(1): 4-21.

Dosskey, M.G., M.J. Helmers, D.E. Eisenhauer, T.G. Franti, and K.D. Hoagland. 2002. Assessment of concentrated flow through riparian buffers. J. Soil Water Conserv. 57(6): 336-343.

Dosskey, M.G., M.J. Helmers, and D.E. Eisenhauer. 2008. A design aid for determining width of filter strips. J. Soil Water Conserv. 63(4): 232-241.

Drinkwater, L.E., P. Wagoner, and M. Sarrantonio. 1998. Legume-based cropping systems have reduced carbon and nitrogen losses. Nature. 396(6708): 262-265.

Engeland, K., I. Barud, L. Gottschalk, and E. Leblois. 2006. Multiobjective regional modelling. J. Hydrol. 327(3-4): 339-351.

Flowers, J.D., J.R. Williams, and L.M. Hauck. 1996. NPP Integrated Modeling System: Calibration of the APEX Model for Dairy Waste Application Fields in Erath County, Texas. PR 96-07, Texas Inst Appl. Environ. Res., Tarleton State Univ., Stephenville, Tex.

Francos, A., F.J. Elorza, F. Bouraoui, G. Bidoglio, and L. Galbiati. 2003. Sensitivity analysis of distributed environmental simulation models: understanding the model behaviour in hydrological studies at the catchment scale. Reliab. Eng. Syst. Safe. 79(2): 205-218.

Franti, T.G. 1997. Vegetative filter strips for agriculture. Nebraska Cooperative 
Extension NF 97 352. Available at Available at http://www.p2pays.org/ref/20/19730.htm (verified 23 February 2013).

Galloway, J.N., E.B. Cowling, S.P. Seitzinger, and R.H. Socolow. 2002. Reactive Nitrogen: Too Much of a Good Thing? AMBIO. 31(2): 60-63.

Garrett, H.E., W.B. Kurtz, M.A. Lassoie, M.A. Gold, H.A. Pearson, L.H. Hardesty, and J.P. Slusher. 1994. Agroforestry: An integrated land use management system for production and farmland conservation. Final Report for the USDA Soil Conservation Service Project. USDA SCS 68-3A75-3-134: Resource Conservation Act Appraisal, Soil Conservation Service, Washington, D.C.

Gassman, P.W. 1997. National Pilot Program Integrated Modeling System: Environmental Baseline Assumptions and Results for the APEX Model. Livestock Series Report 9, The. Center for Agricultural and Rural Development (CARD) at Iowa State University.

Gassman, P.W., J.R. Williams, V.W. Benson, R.C. Izaurralde, L.M. Hauck, C.A. Jones, J.D. Atwood, J.R. Kiniry, and J.D. Flowers. 2005. Historical development and applications of the EPIC and APEX models. Center for Agricultural and Rural Development, Iowa State University.

Gassman, P.W., M. Reyes, C.H. Green, and J.G. Arnold. 2007. The soil and water assessment tool: Historical development, applications and, future directions. Trans. ASAE. 50: 1211-1250.

Gassman, P.W., J.R. Williams, X. Wang, A. Saleh, E. Osei, L. Hauck, C. Izaurralde, and J. Flowers. 2009. The Agricultural Policy Environmental Extender (APEX) model: An emerging tool for landscape and watershed environmental analyses. Center for Agricultural and Rural Development (CARD) Publications, AmesAvailable at http://www.public.iastate.edu/ marks/apex\%20review\%20report\%20scedit\%20(draft\%20CARD\%20report).doc (verified 19 October 2012).

Gassman, P.W., J.R. Williams, X. Wang, A. Saleh, E. Osei, L.M. Hauck, R.C. Izaurralde, and J.D. Flowers. 2010. Invited reviewarticle: The Agricultural Policy/Environmental eXtender model: An emerging tool for landscape and watershed environmental analysis. Trans. ASAE. 53(3): 711-740.

Gharabaghi, B., R.P. Rudra, and P.K. Goel. 2006. Effectiveness of vegetative filter strips in removal of sediments from overland flow. Water quality research journal of Canada 41(3): 275-282.

Ghidey, F., E.J. Sadler, R.N. Lerch, and C. Baffaut. 2007. Scaling up the SWAT model from Goodwater Creek Experimental Watershed to the Long Branch watershed. 
Paper number 072043. In Minneapolis, Minnesota.

Gold, M.A., and H.E. Garrett. 2009. Agroforestry Nomenclature, concepts, and practices. In North American agroforestry. An integrated science and practice. H.E. Garrett. ASA, Madison, WI.

Green, W.H., and G.A. Ampt. 1911. Studies on soil physics: 1. Flow of air and water through soils. J. Agric. Sci. 4: 1-24.

Van Griensven, A., T. Meixner, S. Grunwald, T. Bishop, M. Diluzio, and R. Srinivasan. 2006. A global sensitivity analysis tool for the parameters of multi-variable catchment models. J. Hydrol. 324(1-4): 10-23.

Guertin, D.P., S.N. Fiedler, S.N. Miller, and D.C. Goodrich. 2000. Fuzzy logic for watershed assessment. In Watershed Management. Collins, CO.

Gupta, H.V., S. Sorooshian, and P.O. Yapo. 1998. Toward improved calibration of hydrologic models: Multiple and noncommensurable measures of information. Water Resour. Res. 34(4): 751-763.

Gupta, H.V., S. Sorooshian, and P.O. Yapo. 1999. Status of automatic calibration for hydrologic models: Comparison with multilevel expert calibration. J. Hydraul. Eng. 4(2): 135-143.

Hansen, N.C., T.C. Daniel, A.N. Sharpley, and J.L. Lemuyon. 2002. The fate and transport of phosphorous in agricultural systems. J. Soil Water Conserv. 57(6): 408-417.

Hargreaves, G.H., and Z.A. Samani. 1985. Reference crop evapo-transpiration from temperature. Applied Eng. Agric. 1: 96-99.

Harman, W.L., E. Wang, and J.R. Williams. 2004. Reducing atrazine losses: Water quality implications of alternative runoff control practices. J. Environ. Qual. 33(1): 7-12.

Hayes, J.C., B.J. Barfield, and R.I. Bamhisel. 1979. Filtration of sediment by simulated vegetation. Part II: unsteady flow with non-homogeneous sediment. Trans. ASAE 22(5): 1063-1067.

Hayes, J.C., B.J. Barfield, and R.I. Bamhisel. 1984. Performance of grass filters under laboratory and field conditions. Trans. ASAE 27(5): 1321-1331.

Helmers, M.J., D.E. Eisenhauer, T.G. Franti, and M.G. Dosskey. 2005. Modeling sediment trapping in a vegetative filter accounting for converging overland flow. Trans. ASAE 48(2): 541-555. 
Helms, J.D. 2003. The evolution of conservation payments to farmers. In Compensating Landowners for Conserving Agricultural Land. U.C. Davis Community Studies Extension Conference.

Heuvelink, G.B.M. 1998. Uncertainty analysis in environmental modelling under a change of spatial scale. Nutr. Cycl. Agroecosys. 50(1): 255-264.

Holland, E.A., and D.C. Coleman. 1987. Litter placement effects on microbial and organic matter dynamics in an agroecosystem. Ecology 68: 425-433.

Intarapapong, W., and D. Hite. 2003. Watershed-level policies to implement best management practices under environmental risk. p. 1-5. In Southern Agricultural Economics Association Annual Meeting, Feb.

Jackson, L.L. 2002. Restoring prairie processes to farmlands. p. 137-154. In The Farm as Natural Habitat. D.L. Jackson and L.L. Jackson. Island Press, Washington, D.C.

Jackson, D.L., and L. Jackson. 2002. The Farm as natural habitat: Reconnecting food systems with ecosystems. Island Press, 1718, Connecticut Avenue, N.W.., Siute 300, Washington DC.

Karlen, D.L., M.D. Tomer, J. Neppel, and C.A. Cambardella. 2008. A preliminary watershed scale soil quality assessment in north central Iowa, USA. Soil Till. Res. 99(2): 291-299.

Kazemi, H.V., S.H. Anderson, K.W. Goyne, and C.J. Gantzer. 2008. Atrazine and Alachlor Transport in Claypan Soils as Influenced by Differential Antecedent Soil Water Content. J. Environ. Qual. 37(4): 1599.

King, K.W., J.G. Arnold, and R.L. Bingner. 1999. Comparison of Green-Ampt and curve number methods on Goodwin Creek watershed using SWAT. Trans. ASAE 42(4): 919-925.

King, K.W., P.C. Smiley, B.J. Baker, and N.R. Fausey. 2008. Validation of paired watersheds for assessing conservation practices in the Upper Big Walnut Creek watershed, Ohio. J. Soil Water Conserv. 63(6): 380-395.

Knisel, W.G. 1980. CREAMS: A field-scale model for chemicals, runoff, and erosion from agricultural management system. USDA-SEA, Washington, D.C.

Knowler, D., and B. Bradshaw. 2007. Farmers' adoption of conservation agriculture: A review and synthesis of recent research. Food Policy 32(1): 25-48.

Komor, S.., and J.A. Magner. 1996. Nitrate in groundwater and water sources used by riparian trees in an agricultural watershed: a chemical and isotopic investigation 
in southern Minnesota. Water Resour. Res. 32: 1039-1050.

Kosko, B., and S. Isaka. 1993. Kosko, B., and S. Isaka. 1993. Fuzzy Logic. Scientific American. 269:76 - 81. Sci. Am. 269: 76-81.

Kumar, S., R.P. Udawatta, S.H. Anderson, and A. Mudgal. 2011. APEX model simulation of runoff and sediment losses for grazed pasture watersheds with agroforestry buffers. Agroforest. Syst. 83(1): 51-62.

Kumar, S., S.H. Anderson, R.P. Udawatta, and R.L. Kallenbach. 2012. Water infiltration influenced by agroforestry and grass buffers for a grazed pasture system. Agroforest. Syst. 84(3): 325-335.

Lassoie, J.P., L.E. Buck, and D. Current. 2009. .In: Garrett, H.E. (Ed.), North American Agroforestry: An Integrated Science and Practice, second ed. p. 1-24. In Garrett, H.E. Agronomy Society of America, Madison, WI.

Lee, K.H., T.M. Isenhart, R.C. Schultz, and S.K. Mickelson. 2000. Multispecies riparian buffers trap sediment and nutrients during rainfall simulations. J. Environ. Qual. 29: $1200-1205$.

Leonard, R.A., W.G. Knisel, and D.A. Still. 1987. GLEAMS: Groundwater loading effects on agricultural management systems. Trans. ASAE. 30(5): 1403-1428.

Lerch, R.N., and P.E. Blanchard. 2003. Watershed Vulnerability To Herbicide Transport in Northern Missouri and Southern Iowa Streams. Environ. Sci. Technol. 37(24): $5518-5527$.

Lermontov, A., L. Yokoyama, M. Lermontov, and M.A.S. Machado. 2011. A Fuzzy Water Quality Index for Watershed Quality Analysis and Management. Available at http://www.intechopen.com/books/environmental-management-inpractice/a-fuzzy-water-quality-index-for-watershed-quality-analysis-andmanagement (verified 9 April 2013).

Liu, X., X. Zhang, and M. Zhang. 2008. Major factors influencing the efficacy of vegetated buffers on sediment trapping: A review and analysis. J. Environ. Qual. 37(5): 1667-1674.

Logan, T.J. 1993. Agricultural best management practices for water pollution control: current issues. Agric. Ecosyst. Environ. 46(1): 223-231.

Lohani, A.K., N.K. Goel, and K.K.S. Bhatia. 2010. Comparative study of neural network, fuzzy logic and linear transfer function techniques in daily rainfallrunoff modelling under different input domains. Hydrol. Process. 25(2): 175193. 
Lowrance, R.R., R.L. Todd, J. Fail, O. Hendrickson, R. Leonard, and L.E. Asmussen. 1984. Riparian forests as nutrient filters in agricultural watersheds. J. Biosci. 34: 374-377.

Magette, W.L., R.E. Brinsfield, R.E. Palmer, and J.D. Wood. 1989. Nutrient and sediment removal by vegetated filter strips. Trans. ASAE. 32: 663-667.

Mahabir, C., F.E. Hicks, and A.R. Fayek. 2003. Application of fuzzy logic to forecast seasonal runoff. Hydrol. Process 17(18): 3749-3762.

Maskina, M.S., J.F. Power, J.W. Doran, and W. Wilhelm. 1993. Residual effects of notill crop residues on corn yield and nitrogen uptake. Available at http://digitalcommons.unl.edu/usdaarsfacpub/90/ (verified 6 April 2013).

McDowell, R.W., A.N. Sharpley, and P.J.A. Kleinman. 2002. Integrating phosphorous and nitrogen decision managment at watershed scales. J. Am. Water Resour. As. 38(2): 479-491.

McMichael, C.E., A.S. Hope, and H.A. Loaiciga. 2006. Distributed hydrological modeling in California semi-arid shrublands: MIKESHE model calibration and uncertainty estimation. J. Hydrol. 317: 307-324.

Mervin, M.L. (ed). 1997. The Status, Opportunities and Needs for Agroforestry in the United States. A National Report. Association for Temperate Agroforestry, Lexington, KY.

Missouri Department of Natural Resources. 2012. Missouri water quality report (Section 305(b) report). Available at http://www.dnr.mo.gov/env/wpp/waterquality/305b/2012-305b.pdf (verified 30 March 2013).

Mitra, B., H.D. Scott, J.C. Dixon, and J.M. McKimmey. 1998. Applications of fuzzy logic to the prediction of soil erosion in a large watershed. Geoderma 86(3): 183-209.

Mitsch, W.J., J.W. Day, J. Wendell Gilliam, P.M. Groffman, D.L. Hey, G.W. Randall, and N. Wang. 2001. Reducing Nitrogen Loading to the Gulf of Mexico from the Mississippi River Basin: Strategies to Counter a Persistent Ecological Problem. BioScience 51(5): 373.

Monteith, J.L. 1965. Evaporation and environment. Symp. Soc. Exp. Biol. 19: 205-234.

Montgomery, D.R. 2007. Soil erosion and agricultural sustainability. Proceedings of the National Academy of Sciences 104(33): 13268-13272.

Moore, I.D., P.E. Gessler, G.A. Nielsen, and G.A. Peterson. 1993. Soil attribute 
prediction using terrain analysis. Soil Sci. Soc. Am. J. 57(2): 443-452.

Moriasi, D.N., J.G. Arnold, M.W. Van Liew, R.L. Bingner, R.D. Harmel, and T.L. Veith. 2007. Model evaluation guidelines for systematic quantification of accuracy in watershed simulations. Trans. ASABE 50(3): 885-900.

Mudgal, A., C. Baffaut, S.H. Anderson, E.J. Sadler, N.R. Kitchen, K.A. Sudduth, and R.N. Lerch. 2012. Using the Agricultural Policy/Environmental eXtender to develop and validate physically based indices for the delineation of critical management areas. J. Soil Water Conserv. 67(4): 284-299.

Mudgal, A., C. Baffaut, S.H. Anderson, E.J. Sadler, and A.L. Thompson. 2008. APEX model assessment of variable landscapes on runoff and dissolved herbicides. In ASABE International Meeting, June.

Muleta, M.K., and J.W. Nicklow. 2005. Sensitivity and uncertainty analysis coupled with automatic calibration for a distributed watershed model. J. Hydrol. 306(1): $127-145$.

Mulla, D.J., A.S. Birr, N.R. Kitchen, and M.B. David. 2005. Evaluating the effectiveness of agricultural management practices at reducing nutrient losses to surface waters. p. 171-193. In Gulf hypoxia and local water quality concerns. Iowa state university. Ames. Iowa.

Munos-Carpena, R., J.E. Parsons, and J.W. Gilliam. 1999. Modeling hydrology and sediment transport in vegetative filter strips. J. Hydrol. 214: 111-129.

Nair, V.D., and D.A. Gractz. 2004. Agroforestry as an approach to minimizing nutrient loss from heavily fertilized soils: The Florida experience. Adv. Agrofor. 1: 269279.

Nash, J.E., and J.V. Sutcliffe. 1970. River flow forecasting through conceptual models part I — A discussion of principles. J. Hydrol. 10(3): 282-290.

National Academy of Sciences. 1986. Soil Conservation: Assessing the National Resources Inventory. Vol. 1. National Academy Press, Washington, DC.

Neibling, W.H., and E.E. Alberts. 1979. Composition and yield of soil particles transported through sod strips. p. 12. In Summer Meeting of the ASAE and CSAE. Paper No. 79-2065. St. Joseph, MI.

Onstard, C.A., and G.R. Foster. 1975. Erosion modeling on a watershed. Trans. ASAE. 18(2): 288-292.

Osei, E., P.W. Gassman, and A. Saleh. 2000. Livestock and the environment: A national pilot project: Economic and environmental modeling using CEEOT. Report No. 
PR0002. Stephenville, Tex.: Tarleton State University, Texas Institute for Applied Environmental Research. Available at http://tiaer.tarleton.edu/pdf/PR0002.pdf (verified 9 April 2013).

Oudin, L., F. Hervieu, C. Michel, C. Perrin, V. Andréassian, F. Anctil, and C. Loumagne. 2005. Which potential evapotranspiration input for a lumped rainrunoff model? Part 2 - Towards a simple and efficient potential evapotranspiration model for rainfall-runoff modelling. J. Hydrol. 303: 290-306.

Parajuli, P.B., K.R. Mankin, and P.L. Barnes. 2008. Applicability of targeting vegetative filter strips to abate fecal bacteria and sediment yield using SWAT. Agr. Water Manage. 95(10): 1189-1200.

Pearce, R.A., M.J. Trlica, W.C. Leininger, J.L. Smith, and G.W. Frasier. 1997. Efficiency of grass buffer strips and vegetation height on sediment filtration in laboratory rainfall simulations. J. Environ. Qual. 26(1): 139-144.

Pechlivanidis, I.G., B.M. Jackson, N.R. Mcintyre, and H.S. Wheater. 2011. Catchment scale hydrological modelling: a review of model types, calibration approaches and uncertainty analysis methods in the context of recent developments in technology and applications. Global Nest J. 13(3): 193-214.

Penman, H.L. 1948. Natural evaporation from open water, bare soil, and grass. p. 120145. In Proc. Royal Soc. London A 193(1032).

Phillips, J.D. 1989. An evaluation of the factors determining the effectiveness of water quality buffer zones. J. Hydrol. 107: 133-145.

Pimental, D. 2006. Soil erosion: A food and environmental threat. Environ. Dev. Sustain. 8: 119-137.

Pimental, D., C. Harvey, K. Resossudarmo, K. Sinclair, M. Kurz, M. McNair, S. Crist, L. Shpritze, L. Fitton, R. Saffouri, and R. Blair. 1995. Environmental and economic costs of soil erosion and conservation benefits. Science 267: 11171122.

Priestley, C.H.B., and R.J. Taylor. 1972. On the assessment of surface heat flux and evaporation using large-scale parameters. Mon. Weather Rev. 100(2): 81-92.

Refsgaard, J.C. 1997. Parameterisation, calibration and validation of distributed hydrological models. J. Hydrol. 198(1-4): 69-97.

Reginato, M., and T.C. Piechota. 2004. Nutrient contribution of nonpoint source runoff in the Las Vegas valley1. J. Am. Water Resour. As. 40(6): 1537-1551.

Renard, K.G., G.R. Foster, G.A. Weesies, D.K. McCool, and D.C. Yoder. 1997. 
Predicting soil erosion by water: A guide to conservation planning with the Revised Universal Soil Loss Equation (RUSLE).

Robinson, C.A., M. Ghaffarzaddeh, and R.M. Cruse. 1996. Vegetative filter strip effects on sediment concentration in cropland runoff. J. Soil Water Conserv. 50: 227 230 .

Rose, C.W., B. Yu, W.L. Hogarth, A.E.A. Okom, and H. Ghadiri. 2003. Sediment deposition from flow at low gradients into a buffer strip - a critical test of reentrainment theory. J. Hydrol. 280(1-4): 33-51.

Ross, T. 2004. Fuzzy logic with engineering applications. John Wiley and Sons Ltd. The Atrium, Southern gate, Chichester, West Sussex, England.

Ruan, H., and T.H. Illangasekare. 1998. Ruan H., and T.H. Illangasekare TH. 1998. A model to couple overland flow and infiltration into a macroporous vadose zone. J. Hydrol.. 210:116- 127. J. Hydrol. 210: 116-127.

Saleh, A., J.R. Williams, J.C. Wood, L.M. Hauck, and W.H. Blackburn. 2004. Application of APEX for forestry. Available at http://ddr.nal.usda.gov/handle/10113/9677 (verified 29 January 2013).

Schmitt, T.J., M.G. Dosskey, and K.D. Hoagland. 1999. Filter strip performance and processes for different vegetation, widths, and contaminants. J. Environ. Qual. 28(5): 1479-1489.

Schultz, R.C., T.M. Isenhart, W.W. Simpkins, and J.P. Colletti. 2004. Riparian forest buffers in agroecosystems-lessons learned from the Bear Creek Watershed, central Iowa, USA. Agroforest. Syst. 61(1-3): 35-50.

Schultz, R.C., T.M. Isenhart, J.P. Colletti, W.W. Simpkins, R.P. Udawatta, and P.L. Schultz. 2009. Riparian and upland buffer practices. p. 163-217. In North American agroforestry: An integrated science and practice. H. E. Garrett (ed.). ASA, Madison, WI.

Sen, M. 2009. Fuzzy Logic and hydrology modeling. p. 348. In CRC Press, Taylor \& Francis group, Broken Sound Parkway, NW.

Senaviratne, G.M.M.M.A., R.P. Udawatta, K.A. Nelson, K. Shannon, and S. Jose. 2012. Temporal and Spatial Influence of Perennial Upland Buffers on Corn and Soybean Yields. Agron. J. 104(5): 1356-1362.

Sharpley, A.N., S.J. Smith, O.R. Jones, W.A. Berg, and G.A. Coleman. 1992. The transport of bioavailable phosphorus in agricultural runoff. J. Environ. Qual. 21(1): 30-35. 
Sharpley, A.N., J.L. Weld, D.B. Beegle, P.J.A. Kleinman, W.J. Gburek, P.A. Moore Jr., and G. Mullins. 2003. Development of phosphorus indices for nutrient management planning strategies in the United States. J. Soil Water Conserv. 58: $137-152$.

Silvert, W. 2000. Fuzzy indices of environmental conditions. Ecol. Model. 130(1): 111119.

Singh, V.P., and D.K. Frevert. 2006. Watershed models. CRC Press, Taylor \& Francis Group, Boca Raton, FL.

Smettem, K.R., D.J. Chillebrough, B.G. Richards, and F.W. Leaney. 1991. , K.R.J, D.J. Chillebrough, B.G. Richards, and F.W. Leaney. 1991. The influence of macropores on runoff generation from a hillslope soil with a contrasting textural class. J. Hydrol. 122: 235-252.

Srivastava, P., K.W. Migliaccio, and J. Simunek. 2007. Landscape models for simulating water quality at point, field, and watershed scales. Trans. ASABE. 50: 1683-1693.

Stevenson, F.J. 1982. Organic forms of soil nitrogen. p. p. 67-122. In Nitrogen in agricultural soils. F. J. Stevenson. ASA, Madison, WI.

Stolte, J., C.J. Ritsema, and A.P.J. Roo. 1997. Effects of crust and cracks on simulated catchment discharge and soil loss. J. Hydrol. 195: 279-290.

Tayfur, G., S. Ozdemir, and V.P. Singh. 2003. Fuzzy logic algorithm for runoff-induced sediment transport from bare soil surfaces. Adv. Water Resour. 26(12): 12491256.

Tomer, M.D., M.G. Dosskey, M.R. Burkart, D.E. James, M.J. Helmers, and D.E. Eisenhauer. 2009. Methods to prioritize placement of riparian buffers for improved water quality. Agroforest. Syst. 75(1): 17-25.

Tran, L.T., M.A. Ridgley, L. Duckstein, and R. Sutherland. 2002. Application of fuzzy logic-based modelling to improve the performance of the revised universal soil loss equation. Catena 47: 203-226.

Tuppad, P., M.F. Winchell, X. Wang, R. Srinivasan, and J.R. Williams. 2009. ArcAPEX: ArcGIS interface for Agricultural Policy Environmental eXtender (APEX) hydrology/water quality model. Intl. Agric. Eng. J. 18(1): 59.

Tuppad, P., C. Santhi, X. Wang, J.R. Williams, R. Srinivasan, and P.H. Gowda. 2010. Simulation of conservation practices using the APEX model. Appl. Eng. in Agric. 26(5): 779-794. 
Udawatta, R.P., J.J. Krstansky, G.S. Henderson, and H.E. Garrett. 2002. Agroforestry practices, runoff, and nutrient loss. J. Environ. Qual. 31(4): 1214-1225.

Udawatta, R.P., G.S. Henderson, J.R. Jones, and R.D. Hammer. 2006. Runoff and sediment from row-crop, row-crop with grass strips, pasture, and forest watersheds. J. Water Sci. 19: 137-149.

Udawatta, R.P., R.J. Kremer, B.W. Adamson, and S.H. Anderson. 2008. Variations in soil aggregate stability and enzyme activities in a temperate agroforestry practice. Appl. Soil Ecol. 39(2): 153-160.

Udawatta, R.P., and S.H. Anderson. 2008. CT-measured pore characteristics of surface and subsurface soils influenced by agroforestry and grass buffers. Geoderma 145(3-4): 381-389.

Udawatta, R.P., H.E. Garrett, and R. Kallenbach. 2011. Agroforestry buffers for nonpoint source pollution reductions from agricultural watersheds. J. Environ. Qual. 40(3): 800-806.

USDA/NRCS. 1986. U.S. Department of Agriculture, Soil Conservation Service. Urban hydrology for small watersheds. Tech. Release. Report no. 55. Department of Agriculture, Soil Conservation Service.

USDA/NRCS. 2000. Missouri National Resources Inventory Soil Erosion Tables. Columbia, MO: USDA Natural Resources Conservation Service. Available at http://www.nrcs.usda.gov/wps/portal/nrcs/main/mo/technical/dma/nri/ (verified 4 March 2013).

USDA/NRCS. 2004. Guide for estimating participation in conservation programs and projects. Available at http://www.nrcs.usda.gov/Internet/FSE_DOCUMENTS/nrcs143_021821.pdf (verified 12 March 2013).

USDA/NRCS. 2007. Grassed waterways. Chapter 7. In National engineering handbook: Pt. 650, Engineering field handbook. Available at http://directives.sc.egov.usda.gov/OpenNonWebContent. aspx? content $=17766$. wba (verified 8 February 2010).

USEPA, (U.S. Environmental Protection Agency). 2013. National Summary of State Information. Available at http://ofmpub.epa.gov/waters10/attains_nation_cy.control\#status_of_dataon_cy.c ontrol (verified 30 March 2013).

Viaud, V., P. Merot, and J. Baudry. 2004. Hydrochemical Buffer Assessment in Agricultural Landscapes: From Local to Catchment Scale. J. Environ. Manage. 
34(4): 559-573.

Vidon, P., and A.R. Hill. 2004. Landscape controls on nitrate removal in stream riparian zones. Water Resour. Res. 40.

Vrugt, J.A., B.A. Robinson, and J.M. Hyman. 2009. Self-Adaptive Multimethod Search for Global Optimization in Real-Parameter Spaces. IEEE T. Evolut. Comput. 13(2): 243-259.

Wagner, F.H., and G. Bretschko. 2003. Riparian trees and flow paths between hyporheic zone and groundwater in Oberer Seebach, Austria. Intl. Rev. Hydrobiol. 88: 129138.

Wang, X., P.W. Gassman, J.R. Williams, S. Potter, and A.R. Kemanian. 2008. Modeling the impacts of soil management practices on runoff, sediment yield, maize productivity, and soil organic carbon using APEX. Soil Till. Res. 101(1): 78-88.

Wang, X., X. He, J.R. Williams, R.C. Izaurralde, and J.D. Atwood. 2005. Sensitivity and uncertainty analyses of crop yields and soil organic carbon simulated with EPIC. Trans. ASAE. 48(3): 1041.

Wang, X., A. Saleh, M.W. McBroom, J.R. Williams, and L. Yin. 2007. Test of APEX for Nine Forested Watersheds in East Texas. J. Environ. Qual. 36(4): 983-995.

Wang, X., J.R. Williams, P.W. Gassman, C. Baffaut, R.C. Izaurralde, J. Jeong, and J.R. Kiniry. 2012. EPIC and APEX: Model use, calibration, and validation. Trans. ASABE. 55(4): 1447-1462.

Williams, J.R. 1975. Sediment routing for agricultural watersheds. Water Resour. Bull. 11: 965-974.

Williams, J.R. 1995. The EPIC model. p. 909-1000. In Computer models in watershed hydrology. V.P. Singh (ed.). Water Resources Publications, Highlands Ranch, $\mathrm{CO}$.

Williams, J.R., J.G. Arnold, R. Srinivasan, and T.S. Ramanarayanan. 1998. APEX: A new tool for predicting the effects of climate and $\mathrm{CO} 2$ changes on erosion and water quality. NATO ASI Series 1: 441-449.

Williams, J.R., W.L. Harman, M. Magre, U. Kizil, J.A. Lindley, G. Padmanabhan, and E. Wang. 2006. APEX feedlot water quality simulation. Trans. ASABE. 49(1): $61-73$.

Williams, J.R., and R.C. Izaurralde. 2006. The APEX model. In Watershed Models. p. 437-482. In V. P. Singh and D. K. Frevert. CRC Press, Boca Raton, Fl. 
Williams, J.R., R.C. Izaurralde, and E.M. Steglich. 2008. Agricultural policy/environmental extender model: User's manual version 0604. BREC Report \#2008-16. Blackland Research and Extension Center. p. 222. Available at http://epicapex.brc.tamus.edu/downloads/usermanuals.aspx. (verified 12 June 2012).

Williams, J., S. Potter, X. Wang, J. Atwood, L. Norfleet, T. Gerik, J. Lemunyon, A. King, E. Steglich, and C. Wang. 2010. APEX Model Validation for CEAP. Available at ftp://ftpnhq.sc.egov.usda.gov/NHQ/nri/ceap/APEX_Model_Validation_for_CEAP.pdf (verified 30 January 2013).

Wischmeier, W.H., and D.D. Smith. 1978. Predicting rainfall erosion losses, a guide to conservation planning. Hand book No. 573. United States Department of Agriculture, Agricultural Experiment Station, Purdue.

Yin, L., X. Wang, J. Pan, and P.W. Gassman. 2009. Evaluation of APEX for daily runoff and sediment yield from three plots in the Middle Huaihe River Watershed, China. Trans. ASABE. 52(6): 1833-1845.

Young, R.A., C.A. Onstard, D.D. Bosch, and W.P. Anderson. 1987. AGNPS, Agricultural nonpoint-source pollution model: A watershed analytical tool. USDA, Washington, D.C.

Zadeh, L.A. 1965. Fuzzy sets. Inform. Control 8: 338-353.

Zhang, X., R. Srinivasan, K. Zhao, and M.V. Liew. 2009. Evaluation of global optimization algorithms for parameter calibration of a computationally intensive hydrologic model. Hydrol. Process. 23(3): 430-441.

Zhu, A.X., B. Hudson, J. Burt, K. Lubich, and D. Simonson. 2001. Soil mapping using GIS, expert knowledge, and fuzzy logic. Soil Sci. Soc. Am. J. 65(5): 1463-1472. 


\title{
3. CHAPTER
}

\section{APEX SIMULATION OF THREE ADJACENT ROW-CROP WATERSHEDS IN THE CLAYPAN REGION}

\begin{abstract}
The Agricultural Policy Environmental Extender (APEX) model is used to evaluate best management practices on pollutant loading in whole farms or small watersheds. The study objectives were to conduct a sensitivity analysis to determine the effect of model parameters on APEX output, and then use the parameterized, calibrated, and validated model to evaluate long-term benefits of grass waterways. APEX was used to model three (East, Center, and West) adjacent field-size watersheds with claypan soils under a no-till corn (Zea mays L.)/soybean [Glycine max (L.) Merr.] rotation. Twenty seven parameters were sensitive for crop yield, runoff, sediment, nitrogen (dissolved and total), and phosphorous (dissolved and total) simulations. The model was calibrated using measured event-based data from the Center watershed from 1993 to 1997 and validated with data from the West and East watersheds. Simulated crop yields were within $\pm 13 \%$ of the measured yield. The model performance for event-based runoff was excellent, with calibration and validation coefficients of determination $\left(r^{2}\right)>0.9$ and Nash-Sutcliffe Coefficients (NSC) $>0.8$, respectively. Sediment and total nitrogen (TN) calibration results were satisfactory for larger rainfall events $(>50-\mathrm{mm})$ with $r^{2}>0.5$ and NSC > 0.4 but validation results remained poor with NSC between 0.18 and 0.3. Total phosphorous (TP) was well calibrated and validated with $r^{2}>0.8$ and NSC $>0.7$,
\end{abstract}


respectively. Presence of grass waterways reduced annual TP loadings by $13-25 \%$. The replicated study indicates that APEX provides a convenient and efficient tool to evaluate long-term benefits of conservation practices.

\section{Introduction}

Hydrological models provide convenient, efficient, and economically feasible methods to evaluate the impact of conservation management practices on non-point source pollution (NPSP) in agricultural watersheds, provided sufficient measured data are available at objective scales (Gassman et al., 2010). The Agricultural Policy Environmental eXtender (APEX; Williams et al., 1998) is a widely used model that can evaluate sediment and nutrient loads resulting from various land management practices at whole farm to large watershed scale. The distributed, continuous, daily time-step, APEX model was developed as an extension to the Environmental Policy Integrated Climate (EPIC; Williams, 1995) field model. APEX model integrates EPIC components taken from Chemicals, Runoff and Erosion from Agricultural Management Systems (CREAMS; Knisel, 1980), Simulator for Water Resources in Rural Basins (SWRRB; Williams et al., 1985), and Groundwater Loading Effects of Agricultural Management Systems (GLEAMS; Leonard et al., 1987). APEX has added features to simulate flow and route sediment and nutrients between multiple fields called subareas and channel systems to the watershed outlet. This feature of APEX is one of the most comprehensive approaches available in current landscape scale models (Srivastava et al., 2007). APEX also allows watersheds to be subdivided into many subareas to ensure homogeneity of the smallest hydrologic unit in soil, land-use, and management. The 
ArcGIS based ArcAPEX provides a convenient platform to use GIS based custom delineated maps of subareas and stream networks for watershed delineation (Tuppad et al., 2009).

The APEX model has been tested for various land use and land management practices at both field and watershed scales (Williams et al., 2006; Wang et al., 2007; Tuppad et al., 2009; Yin et al., 2009; Mudgal et al., 2010). APEX model has been selected for national scale studies to evaluate effectiveness of vegetative filter strip in controlling sediment and pollutants (Arnold et al., 1998) and to find the benefits of the conservation programs of United States Department of Agriculture-Natural Resources Conservation Service (USDA-NRCS) by the Conservation Effects Assessment Project (CEAP; Wang et al., 2007).

Although many studies present how APEX provides reasonable and accepted results (Williams et al., 2006; Gassman et al., 2010), only a few studies have evaluated the predictability of a calibrated APEX model to reproduce monitored data (Wang et al., 2007; Yin et al., 2009; Mudgal et al., 2010; 2012).

Conservation management practices, such as reduced tillage, no-till, crop rotations, and cover crops have been effective in reducing high soil erosion rates of 17.8$\mathrm{Mg} \mathrm{ha}^{-1}$ in Missouri during the 1980s (National Academy of Sciences, 1986). Still 62\% of the crop land in Missouri loses soil above the tolerance level (USDA-NRCS, 2000). The claypan characteristics enhance surface runoff and surface transport of sediment, nutrients, and herbicides (National Academy of Sciences, 1986; USDA-NRCS, 2000). 
Claypan soils are characterized by an abrupt increase in clay content within 0.1 to $0.5-\mathrm{m}$ depth with clay content varying from 350-600 $\mathrm{gg}^{-1}$ (Miles and Hammer, 1989; BlancoCanqui et al., 2002; USDA-NRCS, 2006). These soils are distributed over a $3 * 10^{6}$-ha area in Missouri, Illinois, and Kansas states (Jamison et al., 1968; Anderson et al., 1990; USDA-NRCS, 2006). Presence of the high shrink-swell, smectitic clay in the subsoil argillic horizons of these soils results in low saturated hydraulic conductivity, poor infiltration, and high runoff rates in these soils (Blanco-Canqui et al., 2002). Many studies at plot and small watershed scales have demonstrated that conservation practices reduce NPSP, but not many of them were evaluated for long-term benefits (Lowrance et al., 1984; Dillaha et al., 1989; Schmitt et al., 1999).

The goal of this study was to evaluate the long-term effects of grass waterways on NPSP by simulating three adjacent corn/soybean rotational watersheds in claypan soils with APEX model. Specific objectives were to (1) conduct a parameter sensitivity analysis to examine the effect of model parameters on model output and model performances of crop yield, runoff, sediment, nitrogen (dissolved and total), and phosphorous (dissolved and total), (2) parameterize, calibrate, and validate the model for crop yield, runoff, sediment, total nitrogen (TN), and total phosphorous (TP) and (3) quantify the long-term reductions in runoff and TP from grass waterways.

\section{Materials and Methods}

\section{Watershed Characteristics}

Long-term data from a paired watershed study located at the University of 
Missouri Greenley Memorial Research Center in Knox County, Missouri, USA was used in the model simulation $\left(40^{\circ} 01^{\prime} \mathrm{N}, 92^{\circ} 11^{\prime} \mathrm{W}\right.$; Fig. 3.1a; Udawatta et al., 2002). Three adjacent North facing field-scale watersheds with grass waterways were established in early 1991, with areas of 1.65 ha (East), 4.44 ha (Center) and 3.16 ha (West). The watersheds had been no-till cultivated with a corn/soybean rotation with rows perpendicular to the slope from 1992 to 1995 (Tilled in 1993). Since 1996, cultivation was along contours.

Major soils of the watersheds are Putnam silt loam (fine, smectitic, mesic Vertic Albaqualf) on 0-1\% slopes and Kilwinning silt loam (fine, smectitic, mesic Vertic Epiaqualf) on 2-5\% slopes. Armstrong loam (fine, smectitic, mesic Aquertic Halpudalf) soils have been found on 5-9\% slopes in minor portions of the watersheds. Mean annual precipitation (30-yr) determined by daily measurements at the Novelty weather station (http://agebb.missouri.edu/) located within 500-m of the watersheds is 920-mm $\mathrm{yr}^{-1}$ with $66 \%$ occurring from April to September. Mean annual air temperature is $11.7^{\circ} \mathrm{C}$ with an average monthly low of $-6.6^{\circ}-\mathrm{C}$ and high of $31.4^{\circ}-\mathrm{C}$. Average snowfall of $590 \mathrm{~mm}$ per year has been recorded, which stays on the ground for extended periods.

Each watershed's grass waterway consisted mainly of fescue grass [Schedonorus phoenix (Scop.) Holub] leading to a concrete approach structure and a H-flume. To record the flow rate and sampling times as well as collect samples, Stevens Type F water level recorders (Stevens Water Resources, Beaverton, OR) were used from 1991 to 
1995. These were replaced by ISCO (Lincoln, NE, USA) bubbler flow measuring devices and ISCO 3700 samplers in August 1995. Water samples were collected from late February/early March to December each year. Flow based samples were collected and combined for each storm event and analyzed for sediment, TN, and TP. Details on sample collection and laboratory procedures can be found in Udawatta et al. (2002). Crop yields of the watersheds were determined by GPS yield data points which were collected with an Ag Leader Technology 2000 (Ames, IA) yield monitor attached to the R50 Gleaner (AGCO Corp., Duluth, GA) combine for corn (5-m swath width) and soybean (5-m swath width) as described in Senaviratne et al. (2012). Grain yields were adjusted for moisture at 150 and $130 \mathrm{~g} \mathrm{~kg}^{-1}$ for corn and soybean, respectively, prior to yield comparisons.

\section{Simulation of Watersheds by APEX}

Three watersheds were simulated using ArcAPEX with custom delineated subareas and stream networks (Fig. 3.1b). ArcGIS 9.3 tools were used to create subareas and stream network maps. The 25 -cm contour survey maps, land-use maps, management information (Udawatta et al., 2002), soil maps (Soil Survey Geographic (SSURGO)), and daily measured weather inputs of precipitation, maximum and minimum temperature, and solar radiation obtained from the Novelty weather station were utilized for model simulations.

Grass waterways were simulated as separate subareas to include perennial vegetation (fescue) and management practices (mowed once a year). The details used to 
define subareas of crop and grass waterways are given in Table 3.1. Further adjustments of the model parameters were done by editing input files created by ArcAPEX, with a text editor according to the guidelines provided in the APEX user manual (Williams et al., 2008a). The model was further upgraded using detailed soil data available from 80 core samples from the three watersheds. Each point data included details on texture, cation exchange capacity, organic carbon content, and $\mathrm{pH}$ for each horizon of the profile up to a $1-\mathrm{m}$ depth. Saturated hydraulic conductivity $\left(\mathrm{k}_{\mathrm{sat}}\right)$, field capacity, permanent wilting point, and bulk density data were not available for every point and representative data available from the findings of Seobi et al. (2005) for different soil depths of the same site were used for defining these properties.

The claypan was specified in the soil files as a separate layer with relevant soil characteristics, i.e. depth to claypan (0.25-65 cm), thickness of argillic horizon (125-150 $\mathrm{cm})$, clay content (28-46\%), bulk density (1.20-1.45 $\left.\mathrm{Mg} \mathrm{m}^{-3}\right)$, and $\mathrm{K}_{\text {sat }}(0.07-0.007 \mathrm{~mm}$ $\mathrm{h}^{-1}$ ). APEX utilizes layer soil properties to estimate soil water transport through the soil profile. Percolation and lateral subsurface flow are simulated as simultaneous processes of flow by the APEX model using storage routing and flow equations controlled by soil water content, $\mathrm{K}_{\text {sat, }}$ porosity, and field capacity. Vertical flow contributes to ground water storage, which in turn is subjected to deep percolation or return flow. Horizontal flow consists of lateral flow which is partitioned between quick return flow that enters the subarea channel and subsurface flow to the subarea (soil water storage) immediately below. This storage routing technique is applied layer by layer from the surface to the deepest layer. If water cannot move downward or laterally because of lower $\mathrm{K}_{\text {sat }}$ of the 
deeper layer or of layer saturation, the excess water is transferred to the layer above. Thus, the effects of the claypan on watershed hydrology are simulated by using soil characteristics of each soil layer entered into the model.

The soil moisture index (SMI) based continuous curve number $(\mathrm{CN})$ method (SCS, 1985; Williams and LaSeur, 1976) was selected for runoff estimation in which, the retention parameter, $s$, is estimated based on soil moisture depletion which is a function of potential evapotranspiration (Williams et al., 2012). The modified rational method (Williams, 1995) was selected for estimating the peak runoff rate. The Hargreaves and Samani (1985) method was preferred for estimating potential evaporation as it generates reasonable values using solar radiation and air temperature as inputs. The modification of Modified Universal Soil Loss Equation (MUSLE) for small watersheds (MUSS; Williams, 1995) was used for estimation of soil erosion. Use of runoff variable in MUSLE rather than rainfall as in Universal Soil Loss Equation (USLE) and Revised Universal Soil Loss Equation (RUSLE) increases the accuracy of estimation of erosion and sediment loss (Williams et al., 2006).

\section{Calibration and validation}

The APEX model was manually calibrated for crop yields, event-based runoff, and losses of sediment, TN, and TP using measured data during 1993 to 1997 from the Center watershed. Dissolved N and DP were not used for calibration and validation because of the lack of measured data. Validation of the model was conducted using data from West and East watersheds over the same period. The use of separate watersheds 
for calibration and validation not only extended the evaluation period but also ensured inclusion of both small and large rainfall events for calibration and validation.

Measured runoff data available for 42 events during the study period were used for calibration and validation. Measured sediment, TN, and TP losses available for 39 events were used for calibration and validation. Data for three events were not available $(18,19$, and 37) due to insufficient runoff volume for sampling and/or instrument errors. Individual crop yield data were not available for watersheds. The average crop yield data available for the watersheds were used for calibration of the model. Validation for crop yield was not performed.

Model performance was evaluated using coefficient of determination (r2) Nash and Sutcliffe coefficient (NSC; Nash and Sutcliffe, 1970), and Percent bias (Pbias). The r2 value indicates the strength of relationship between the observed and simulated values, while NSC quantifies the model performance compared to an arithmetic average of measured data. If the $\mathrm{r} 2$ and NSC values were equal to one, the model prediction would be 'perfect' while it would be considered unacceptable or poor if they were close to zero or negative. Percent bias measures the average tendency of the simulated values to be larger or smaller than their observed ones.

\section{Sensitivity analysis}

Model sensitivity analysis was performed manually for parameters and model outputs using the sensitivity index Eq. [3.1] suggested by Lenhart et al. (2002).

$$
\mathrm{I}=\frac{\left(\mathrm{y}_{2}-\mathrm{y}_{1}\right) / \mathrm{y}_{0}}{2 \Delta \mathrm{x} / \mathrm{x}_{0}}
$$


where, $I$ is the sensitivity index, $y$ is the dependent output model variable, $x$ is the input parameter being changed, $y_{0}$ is the model output calculated using the initial value $x_{0}$ of the parameter $x$. This initial parameter value, $x_{0}$, is varied by $\pm \Delta \mathrm{x}$ to get $x_{1}=x_{0}-\Delta x$ and $x_{2}=x_{0}+\Delta x$ and corresponding $\mathrm{y}$ values, $\mathrm{y}_{1}$ and $\mathrm{y}_{2}$ (Lenhart et al., 2002). All parameters related to crop yield, runoff, sediment, and loadings were changed manually, \pm one unit at a time within the range allowed in the user manual (Williams et al., 2008a). For example, if the range given was $1-1.5$, then the value was adjusted by \pm 0.1 per iteration; if the range was $0.5-10$, then the value was adjusted by \pm 1 . Parameters sensitive for the same output with \pm 0.2 sensitivity indices were given the same rank.

Scenario analysis was conducted to simulate long-term effects of grass waterways using the calibrated and validated APEX model. Model predictions were obtained for average annual runoff and TP losses for 10 and 20 years of establishment of the watersheds with grass waterways. The watersheds were simulated without grass waterways by replacing grasses with crops. Measured weather from 1991 to 2000 was repeated to build 10 and 20-year sequences for the scenario analyses to avoid the interference of climate on interpretation of effectiveness of grass waterways.

\section{Results and Discussion}

\section{Sensitivity analysis}

The model parameters sensitive for simulation of crop yield, runoff, sediment, dissolved nitrogen (DN), TN, dissolved phosphorous (DP), and TP in the APEX model are listed with their respective ranks in Table 3.2. The most common sensitive 
parameter for crop yield (both corn and soybean), runoff, sediment, DN, TN, DP, and TP predictions was the Hargreaves PET equation exponent (P[34]). Both corn and soybean yield predictions were most sensitive to the root growth soil strength parameter $(\mathrm{P}[2]), \mathrm{P}[34]$, Hargreaves PET equation coefficient (P[23]), water stress weighting coefficient $(\mathrm{P}[38])$, and groundwater storage threshold parameter $(\mathrm{P}[40])$. Corn yields were also sensitive to the SCS curve number index coefficient parameter (P[42]).

Sensitivity of the SCS curve number index coefficient $(\mathrm{P}[42])$ for runoff prediction ranked second to $\mathrm{P}[34]$, possibly because of the use of PET in estimating the retention parameter in the variable daily $\mathrm{CN}-\mathrm{SMI}$ method for runoff estimations. The Hargreaves PET equation coefficient (P[23]), Soil evaporation-plant cover factor (P[17]), and RUSLE C-factor coefficient (P[47]) were among the other most sensitive parameters for runoff predictions. These findings were consistent with Mudgal et al. (2010) where they found $\mathrm{P}[34]$ as the most sensitive parameter for simulating daily runoff by the APEX model. Wang et al. (2005) found both $\mathrm{P}[42]$ and $\mathrm{P}[34]$ as the most sensitive parameters for annual runoff predictions but did not state their relative sensitivity. Yin et al. (2009) found CN2 (Curve number for soil moisture condition II) and $\mathrm{P}[42]$ as the most sensitive parameters for daily runoff predictions by the APEX model. The sensitivity of parameters for model outputs varies with the hydrological methods used and the watershed characteristics.

The average upland slope (CHSO) was the most sensitive parameter for sediment load prediction. The Sediment routing exponent (P[18]), Soil evaporation-plant cover 
factor (P[17]), and $\mathrm{P}[34]$ ranked next for sediment prediction. Wang et al. (2005) reported $\mathrm{P}[42], \mathrm{P}[17]$, and $\mathrm{P}[34]$ as the most sensitive parameters for annual sediment predictions while Yin et al. (2009) reported CN2, P[42], and the Peak runoff rate rainfall energy adjustment factor (APM) as the most sensitive parameters for daily sediment predictions for the APEX model.

The most sensitive parameter for event-based DN, TN, DP, and TP predictions in the model was the CHSO. Nutrient outputs were also sensitive to P[17], P[34], and $\mathrm{P}[69]$, a coefficient that adjusts the microbial activity. Dissolved $\mathrm{N}$ was more specifically sensitive to $\mathrm{P}[34], \mathrm{P}[23], \mathrm{P}[42]$, and $\mathrm{P}[16]$, which expands the $\mathrm{CN}$ retention parameter. Dissolved $\mathrm{N}$ was also sensitive to plant available water (difference between the field capacity and permanent wilting point). Both $\mathrm{TN}$ and $\mathrm{TP}$ were also sensitive to $\mathrm{P}[18]$. The Soluble phosphorous runoff coefficient $(\mathrm{P}[8])$ parameter was among the most sensitive parameters for DP predictions which was also reported by Wang et al. (2006). TP was also very sensitive to the selected enrichment ratio method (IERT; control file), and RCHN Channel Manning's N routing reach (Subarea file).

\section{Crop Yield}

Simulated mean crop yields were within $\pm 13 \%$ of the average measured yields of the Center, West, and East watersheds (Figs. 3.2a, b, and c, respectively). Several other studies emphasized the inclusion of crop yields for model calibration especially for good simulation of nutrient balances of the watersheds (Hu et al., 2007; Nair et al., 2011; Mudgal et al., 2012). Arnold et al. (2012) stated that if the crop yields are not well 
simulated, the model may produce errors when evaluating alternative cropping systems and management scenarios. Mudgal et al. (2012) calibrated the APEX model for crop yields to be within $\pm 9 \%$ of the measured yields and $\mathrm{Hu}$ et al. (2007) calibrated the Soil and Water Assessment Tool (SWAT; Arnold et al., 1998; Arnold and Fohrer, 2005) for corn and soybean yields to be within -10 to $6 \%$ of measured yields.

\section{Runoff, Sediment, TN and TP Losses}

The APEX model was calibrated using measured event-based data from the Center watershed for the period, 1993-1997, for runoff (Fig. 3.3a), sediment (Fig 3.4a), TN (Fig. 3.5a), and TP (Fig 3.6a) predictions. The model was validated with measured event-based data from the two watersheds, West (Figs. 3.3b, 3.4b, 3.5b, and 3.6b) and East (Figs 3.3c, 3.4c, 3.5c, and 3.6c) for the respective model outputs for the same period.

The model predicted runoff with $r^{2}>0.9$ and NSC $>0.8$ for both calibration and validation (Table 3.3). Pbias values ranged from 4 to $26 \%$. The model did not simulate event-based sediment (Fig 3.4), TN (Fig. 3.5), and TP (Fig 3.6) well enough for calibration when all the events were considered. Results were satisfactory for sediment, TN, and TP when events 25 to 42 (1995-1997) were considered. These events included 12 large rainfall events (> 50-mm) compared to events 1 to 24 which had only four large rainfall events. Both sediment and $\mathrm{TN}$ were fairly well simulated during the calibration with $r^{2}=0.6$ and NSC $>0.5$ (Pbias $<27 \%$ ) but the validation was weaker (Table 3.3). Total P was well simulated for both calibration and validation with $r^{2}>0.8$ and NSC > 
0.7 (Pbias < 33\%; except for the East watershed; Table 3.3). The model simulations for sediments, TN, and TP improved greatly when moving operation was included in management operations of the grass waterways.

Moriasi et al. (2007) suggested that the model performance could be considered satisfactory for monthly values if NSC is $>0.5$ and if Pbias is $\pm 25 \%$ for stream flow, $\pm 55 \%$ for sediment, and $\pm 70 \%$ for $\mathrm{N}$ and $\mathrm{P}$. They stated that NSC values can be reduced for shorter time steps (daily event) or increased for longer time steps (annual) and stricter performance criterion to be used for calibration than validation because parameters are optimized for calibration. Ramanarayanan et al. (1997) reported that $r^{2}$ and NSC values greater than 0.5 and 0.4 are satisfactory for model predictions of monthly runoff, sediment, and nutrients for the APEX model. Another APEX simulation study reported $r^{2}$ and NSC values between 0.55 to 0.85 and 0.41 to 0.84 , respectively, for event-based runoff and sediment in a plot-scale study in China (Yin et al., 2009). Mudgal et al. (2012) reported $r^{2}$ values around 0.8 and NSC values ranging from 0.72 to 0.78 for simulation of event-based runoff by APEX model. Yuan et al. (2001) reported $r^{2}$ values of 0.8 and 0.5 for event-based runoff and sediment calibration, respectively, for simulation of the Annualized Agricultural Non-Point Source Pollutant Loading model (AnnAGNPS). Chung et al. (2002) have used $r^{2}>0.5$ and NSC $>0.3$ as satisfactory model performance criteria for EPIC model calibration for monthly tile flow and tile $\mathrm{NO}_{3}-\mathrm{N}$ losses. A comparison of model performance of the current study with published results show that the model was reasonably well calibrated and validated for runoff and TP predictions for the three watersheds. Sediment and TN were also 
reasonably calibrated but validation was poor.

The model predictions for average event-based measured runoff did not reflect differences among the watersheds for large rainfall events. For the six largest rainfall events $(12,27,28,32,34$, and 37$)$, the measured event-based average runoff was $24 \%$ and $20 \%$ greater in the West and East watersheds than in the Center watershed, respectively. For the rest of the events measured event-based average runoff was $6 \%$ and $5 \%$ greater in the West and East watersheds than the Center watershed. The respective model simulated watershed differences were $4 \%$ and $5 \%$.

Generally, the Center watershed had the lowest runoff, sediment, TN, and TP loadings and the model respected this trend for all the outputs but with varying degrees. Udawatta et al. (2004) reported the occurrence of surface water crossing natural topographic boundaries, especially to the West watershed, from the west and south boundaries during large rainfall events. This would have caused higher runoff, sediment, TN, and TP losses in the West watershed, despite having the lowest relative slope gradient of $0.9 \%(1.75 \%$ at lower $100 \mathrm{~m})$, and greater relative depth to claypan in both crop areas $(34-35 \mathrm{~cm})$ and grass waterways $(57 \mathrm{~cm})$.

Blanco-Canqui et al. (2002) stated that the shallowness of depth to claypan results in greater runoff and subsequent lateral flow. The Center watershed produced comparatively lower average runoff despite having the shallowest average depth to claypan in the upland crop area (20 to $23 \mathrm{~cm}$; from lower to upper end) compared to the West $(35-57 \mathrm{~cm})$ and East $(32-49 \mathrm{~cm})$ watersheds. The supportive factors such as 
comparatively longer grass waterway (151 m compared to $102 \mathrm{~m}$ of East and $109 \mathrm{~m}$ of West watersheds), higher average depth to claypan in the grass waterway area $(62 \mathrm{~cm}$ compared to $57 \mathrm{~cm}$ of West and $49 \mathrm{~cm}$ of East watersheds), and low slope gradient of $1.3 \%,(2 \%$ at lower $100 \mathrm{~m})$ may have reduced measured runoff, sediment, $\mathrm{TN}$, and TP losses in the Center watershed. The higher measured runoff and the associated sediment, TN, and TP recorded for the East watershed may have been due to its greater relative average gradient $(2.1 \% ; 3 \%$ at lower $100 \mathrm{~m})$, relatively shallow depth to claypan in the grass waterway, and shorter slope length ( $234 \mathrm{~m}$ compared to $425 \mathrm{~m}$ of Center and $383 \mathrm{~m}$ of West watersheds). Watershed characteristics such as slope lengths and slope gradients were incorporated into the model. However, localized variations in depth to the claypan $(10-80 \mathrm{~cm})$ within the watersheds were not incorporated into the model. This may have contributed to differences in simulations among watersheds.

The reason for poorer calibration of sediment with all 39 events as compared to events 25-42 may have been due to under estimation of sediment for small to medium rainfall events. The events 1 to 24 consisted of 12 events with rainfall $\leq 25 \mathrm{~mm}$ while events 25 to 42 had only four events with $\leq 25 \mathrm{~mm}$ rainfall. Measured sediment losses were $<0.01 \mathrm{~T} \mathrm{ha}^{-1}$ for small to moderate runoff events $(12,14,16,23,26,27,28,29$, and 39) except for the two very large events (32 and 34). Udawatta et al. (2004) did not report any textural analysis of the measured sediment but they had observed sediment depositions on flume beds (R. P. Udawatta, 2012, personal communication). This may have caused under estimation of coarse fragments. During larger events, high flow energy may have suspended coarser particles long enough for sampling. Mudgal et al. 
(2012) also reported poor calibration for sediment by APEX for a 35 ha agricultural field located in the Goodwater Creek Experimental Watershed in Missouri. The difference was attributed to underestimation of sediment due to depositions at the weirs. In addition to measurement error, they also reported that the APEX model over-predicted sediment for small events and under-predicted sediment for large events. Similarly, the model under-predicted sediments for two very large events (32 and 34) in the current study as well. Accurate measurement of sediment would improve model calibration for sediment while the causes for under-prediction of sediment for larger events need to be addressed in the model algorithm. Average event-based measured sediment for the Center watershed was 7\% and 3\% less than the West and East watersheds, respectively, and the model simulated those differences as $5 \%$ and $17 \%$, respectively. Inherent watershed differences (Udawatta et al., 2004) such as; distribution of depth to claypan, slope, slope length, and percent land under grass waterways may have contributed to these differences.

Simulated TN showed a better correlation with measured values than sediment but small NSC values indicated a wide variation between the simulated and measured values. The differences among watersheds were large for average event-based measured TN. Udawatta et al. (2006) reported that most of the smaller events had greater concentrations of measured TN than larger events for the same watersheds, possibly due to dilution. They stated that TN losses were complex, not well correlated with runoff, and mainly transported in the soluble form. The West and East watersheds had 95\% and 107\% greater measured TN losses than the Center watershed, respectively, and the 
model simulated $87 \%$ and $73 \%$ greater losses in the respective order.

Better model calibration for TP than for sediments may be partly due to the association of TP with finer clay particles, which stay in the suspension for longer periods for representative sampling. Udawatta et al. (2004) did not find a linear relationship between $\mathrm{TP}$ and sediment but found a significant curvilinear relationship. They observed that up to a certain sediment loss, TP increased at an increasing rate but declined with subsequent increases sediment losses. Other studies have shown that an increase in sediment loss was proportionate to increases of silt-size particles rather than clay-size particles in the runoff (Sharpley et al., 1992; Wall et al., 1996). Model simulated TP was highly correlated with simulated sediment loading ( $r^{2}$ of 0.9 ) indicating that these complex relationships were not well simulated in the model. Average event-based measured TP of the West and East watersheds were 20\% and 27\% greater than the Center watershed, respectively, and the model reasonably simulated these differences as $13 \%$ and $22 \%$.

\section{Scenario Analysis}

Grass waterways have slightly reduced long-term runoff (Figs. 3.7a, b, and c), and significantly $(\mathrm{p}<0.05)$ reduced average annual TP losses (Figs. 3.7d, e, and f), in the three watersheds after 10 and 20 years of simulation since establishment. Long-term simulations for sediments and $\mathrm{TN}$ were not performed due to poor validation results. The reductions in the long-term average annual runoff due to the presence of grass waterways were small (1-2\%; Fig. 3.7a, b, and c). The runoff reduction for a 20-year 
period was $3-4 \%$ greater than the 10-year period. Hjelmfelt and Wang (1999) reported that grass waterways have great potential for reducing runoff peak discharge and sediment loss, but they were not effective for reducing runoff volume. They reported $5 \%$ average reductions of total runoff by the grass waterways. Fiener and Auerswald (2003) reported $10 \%$ reduction of runoff by v-shaped grass waterways.

The long-term reductions in simulated TP by grass waterways for the East, Center, and West watersheds ranged from 13-25\%. Greatest reductions in TP due to the presence of grass waterways were simulated in the East watershed, possibly due to the higher ratio of grass waterway to total watershed length in the East watershed than in the other two watersheds (44\% East, 35\% Center, and 27\% West; Udawatta et a., 2004). The greater percent of land under grass waterways on the East watershed (9\%) compared to the Center (4.5\%) and West (5.2\%) watersheds also may have contributed to higher reduction in TP losses in the East watershed. The importance of grass waterways was highlighted by their ability to convey channelized runoff at non-erosive velocities from fields to a stable outlet (USDA-NRCS, 2007). A watershed study in Germany found $97 \%$ and $77 \%$ reductions on sediment delivery by a doubled width and flat-bottomed waterway and by a v-shaped grass waterway, respectively, compared to no grass waterway in the watershed (Fiener and Auerswald, 2003). They suggested that the reduced flow velocity was due to doubled width and flat-bottomed grass waterways which caused greater reductions in sediment delivery. 


\section{Conclusions}

A sensitivity analysis for the APEX model was performed on simulated runoff, sediment, DN, TN, DP, TP, and crop yields for the Center watershed to find the most sensitive model parameters. All the simulated model outputs were found to be sensitive to the Hargreaves PET equation exponent (P[34]) parameter. Runoff and corn yield predictions were sensitive to SCS curve number index coefficient (P[42]). Sediment, $\mathrm{TN}$, and TP were sensitive to average upland slope (CHSO) and sediment routing exponent $(\mathrm{P}[18])$. The sensitive parameters listed in this study could be useful for parameterization of the APEX model in the claypan region or in areas where soils have a restrictive layer.

The model was parameterized, calibrated, and validated for crop yields, eventbased runoff, sediment, TN and TP for three field-size adjacent small watersheds with claypan soils under a no-till corn/soybean rotation with grass waterways. The model simulated crop yields were within $\pm 13 \%$ of the measured yields. The model was well calibrated and validated for event-based runoff with $r^{2}$ and NSC between 0.8-0.9. The model was simulated for sediment and TN for larger rainfall events $(>50-\mathrm{mm})$ with $r^{2}>$ 0.5 and NSC > 0.4 but model performance indicators for validation were poor. Total P was better calibrated and validated than sediments and TN, with $r^{2}$ and NSC values between 0.7 and 0.8 for larger rainfall events $(>50-\mathrm{mm})$. The study also emphasizes the importance of accurate sediment measurements during small and medium runoff events to avoid underestimation of sediment loads.

Long-term simulations of watersheds predicted $13-25 \%$ reduction in annual TP 
losses due the presence of grass waterways compared to none confirming the importance of grass waterways in reducing pollutant loadings. These findings also indicate the importance of grass waterways for enhanced environmental benefits. The APEX model provided an efficient tool to simulate the best management practices to evaluate their impact on NPSP reductions.

\section{Acknowledgements}

This work was funded through the University of Missouri Center for Agroforestry under cooperative agreements 58-6227-1-004 with the USDA-ARS. Any opinions, findings, conclusions or recommendations expressed in this publication are those of the authors and do not necessarily reflect the view of the U.S. Department of Agriculture. We would like to express our sincere appreciation to Drs. Verel Benson and Todd Farrand for assistance.

\section{List of References}

Anderson, S.H., C.J. Gantzer, and J.R. Brown. 1990. Soil physical properties after 100 years of continuous cultivation. J. Soil Water Conserv. 45:117-121.

Arnold, J.G., J.D. Atwood, V.W. Benson, R. Srinnivasan, and J.R. Williams. 1998. Potential environmental and economic impacts of implementing national conservation buffer initiative. Sedimentation Control Measures. USDA-NRCS. Staff paper. Washington, DC.

Arnold, J.G., R. Srinivasan, R.S. Muttiah, and J.R. Williams. 1998. Large area hydrologic modeling and assessment part I: Model development. J. Amer. Water Resour. Assoc. 34:73-89.

Arnold, J.G., and N. Fohrer. 2005. SWAT2000: Current capabilities and research opportunities in applied watershed modeling. Hydrol. Process. 19:563-572.

Arnold, J.G., D.N. Moriasi, P.W. Gassman, K.C. Abbaspour, M.J. White, R. Srinivasan, 
C. Santhi, R.D. Harmel, A. van Griensven, M.W. Van Liew, N. Kannan, and M.K. Jha. 2012. SWAT: Model use calibration, and validation. Trans. ASAE 55:1491-1508.

Blanco-Canqui, H., C.J. Gantzer, S.H. Anderson, E.E. Alberts, and F. Ghidey. 2002. Saturated hydraulic conductivity and its impact on simulated runoff for claypan soils. Soil Sci. Soc. Am. J. 66:1596-1602.

Chung, S.W., P.W. Gassman, R. Gu, and R.S. Kanwar. 2002. Evaluation of EPIC for assessing tile flow and nitrogen losses for alternative agricultural management systems. Trans. ASAE 45:1135-1146.

Dillaha, T.A., R.B. Renear, S. Mostaghimi, and D. Lee. 1989. Vegetative filter strips for agricultural nonpoint source pollution control. Trans. ASAE. 32:513-519.

Fiener, P., and K. Auerswald. 2003. Effectiveness of grassed waterways in reducing runoff and sediment delivery from agricultural watersheds. J. Environ. Qual. 32:927-936.

Gassman, P.W., J.R. Williams, X. Wang, A. Saleh, E. Osei, L.M. Hauck, C.R. Izaurralde, and J.D. Flowers. 2010. The Agricultural Environmental eXtender (APEX) model: An emerging tool for landscape and watershed environmental analysis. Trans. ASABE. 53:711-740

Hargreaves, G.H., and Z.A. Samani. 1985. Reference crop evapo-transpiration from temperature. Applied Eng. Agric. 1:96-99.

Hjelmfelt, A., and M. Wang. 1999. Modeling hydrologic and water quality responses to grass waterways. J. Hydrol. Eng. 4:251-256.

Hu, X., G.F. McIsaac, M.B. David, and C.A.L. Louwers, 2007.Modeling riverine nitrate export from an East-Central Illinois watershed using SWAT. J. Environ. Qual. 36:996-1005.

Jamison, V.C., D.D. Smith, and J.F. Thornton. 1968. Soil and water research on a claypan soil. p. 1379. USDA Technical Bulletin.US Government Printing Office, Washington, DC.

Knisel, W.G. 1980. CREAMS: A field-scale model for chemicals, runoff, and erosion from agricultural management systems. USDA Conserv. Res. Rep. 26. USDAARS, Washington, DC.

Lenhart, T., K. Eckhardt, N. Fohrer, and H.G. Frede. 2002. Comparison of two different approaches of sensitivity analysis. Phys. Chem. Earth. 27:645-654.

Leonard, R.A., W.G. Knisel, and D.A. Still. 1987. GLEAMS: Groundwater loading 
effects on agricultural management systems. Trans. ASAE 30:1403-1428.

Lowrance, R.R., R.L. Todd, J. Fail, O. Hendrickson, R. Leonard, and L.E. Asmussen. 1984. Riparian forests as nutrient filters in agricultural watersheds. J. Bioscience. 34:374-377.

Miles, R.J., and R.D. Hammer. 1989. One hundred years of Sanborn field: Soil baseline data. p. 100-108. In J.R. Brown (Ed.).Proceedings of the Sanborn Field Centennial, Publication No.SR-415.University of Missouri. Columbia. MO.

Moriasi, D.N., J.G. Arnold, M.W. Van Liew, R.L. Binger, R.D.Harmel, and T. Veith. 2007. Model evaluation guidelines for systematic quantification of accuracy in watershed simulations. Trans. AS ABE 50:885-900.

Mudgal, A., C. Baffaut, S.H. Anderson, E.J. Sadler, and A.L. Thompson. 2010. APEX model assessment of variable landscapes on runoff and dissolved herbicides. Trans. ASABE 53:1047-1058.

Mudgal, A., C. Baffaut, S.H. Anderson, E.J. Sadler, N.R. Kitchen, K.A. Sudduth, and R.N. Lerch. 2012. Using the Agricultural Policy eXtender to develop and validate physically based indices for the delineation of critical management areas. J. of Soil Water Conserv. 67:282-297.

Nair, S. S., K. W. King, J. D. Witter, B. L. Sohngen, and N. R.Fausey. 2011. Importance of crop yield in calibrating watershed water quality simulation models. J. American Water Res. Assoc. 476:1285-1297.

Nash, J.E., and J.V. Sutcliffe. 1970. River flow forecasting through conceptual models: Part I. A discussion of principles. J. Hydrol. 10:282-290.

National Academy of Sciences. 1986. Soil Conservation: Assessing the National Resources Inventory. Vol. 1.National Academy Press, Washington, DC.

Ramanarayanan, T.S., J.R. Williams, W.A. Dugas, L.M. Hauck, and A.M.S. McFarland. 1997. Using APEX to identify alternative practices for animal waste management. paper no. 972209.ASAE. St. Joseph, MI.

Schmitt, T.J., M.G. Dosskey, and K.D. Hoagland. 1999. Filter strip performance and processes for different vegetation, widths, and contaminants. J. Environ. Qual. 28:1479-1489.

SCS National Engineering Handbook. 1985. Sec. 4, Hydrology, U.S. Dept. of Agric. Soil Conservation Service, Washington, DC.

Senaviratne, G.M.M.M.A., R.P. Udawatta, K. Nelson, K. Shannon, and S. Jose. 2012. Temporal and spatial influence of perennial upland buffers on corn and soybean 
yields. Agron. J. 104:104:1356-1362.

Seobi, T., S.H. Anderson, R.P. Udawatta, and C.J. Gantzer. 2005. Influence of grass and agroforestry buffer strips on soil hydraulic properties for an Albaqualf. Soil Sci. Soc. Am. J. 69:893-901.

Sharpley, A.N., S.J. Smith, O.R. Jones, W.A. Berg, and G.A. Coleman. 1992. The transport of bioavailable phosphorus in agricultural run-off. J. Environ. Qual. 21:30-35.

Srivastava, P., K.W. Migliaccio, and J. Šimůnek. 2007. Landscape models for simulating water quality at point, field, and watershed scales. Trans. ASABE 50: 1683-1693.

Tuppad, P., M.F. Winchell, X. Wang, R. Srinivasan, and J.R. Williams. 2009. ArcAPEX: ArcGIS interface for Agricultural Policy Environmental eXtender (APEX) hydrology/water quality model. Int. Agr. Eng. J. 18:59-71.

Udawatta, R.P., J.J. Krstansky, G.S. Henderson, and H.E. Garrett. 2002. Agroforestry practices, runoff, and nutrient loss: A paired watershed study. J. Environ. Qual. 31:1214-1225.

Udawatta, R.P., P.P. Motavalli, and H.E. Garrett. 2004. Phosphorus loss and runoff characteristics in three adjacent agricultural watersheds with claypan soils. J. Environ. Qual. 33:1709-1719.

Udawatta RP, P.P Motavalli, H.E. Garrett, and J.J. Krstansky. 2006. Nitrogen and nitrate losses in runoff from three adjacent corn-soybean watersheds. Agric. Ecosyst. Environ. 117:39-48

USDA-NRCS. 2000. Missouri National Resources Inventory Soil Erosion Tables. USDA Natural Resources Conservation Service. Columbia, MO. Available at http://www.mo.nrcs.usda.gov/technical/nri/erosionindex.html. (verified on 5 May 2012).

USDA-NRCS. 2006. Land Resource Regions and Major Land Resource Areas of the United States, the Caribbean, and the Pacific Basin. Agricultural Handbook 296. US Government Printing Office, Washington, DC.

USDA-NRCS. 2007. Grassed waterways. Chapter 7.In National engineering handbook: p. 650, Engineering field handbook. Available at http://directives.sc.egov.usda.gov/OpenNonWebContent.aspx?content=17766.wb a (verified on2 May 2012).

Yin, L., X. Wang, J. Pan, and P.W. Gassman. 2009. Evaluation of APEX for daily 
runoff and sediment yield from three plots in the Upland Huaihe River watershed, China. Trans. ASABE. 52:1833-1845.

Yuan, Y., R.L. Bingner, and R.A. Rebich. 2001. Evaluation of AnnAGNPS on Mississippi Delta MSEA watersheds. Trans. ASAE 44:1183-1190.

Wall, G.J., A.W. Bos, and A.H. Marshall. 1996. The relationship between phosphorus and suspended sediment loads in Ontario watersheds. J. Soil Water Conserv. 51:504-507.

Wang, X., X. He, J.R. Williams, R.C. Izaurralde, and J.D. Atwood. 2005. Sensitivity and uncertainty analyses of crop yields and soil organic carbon simulated with EPIC. Trans. ASAE 48:1041-1054.

Wang, X., S.R. Potter, J.R. Williams, J.D. Atwood, and T. Pitts. 2006. Sensitivity analysis of APEX for national assessment. Trans. ASABE. 49:679-688.

Wang, X., A. Saleh, M.W. McBroom, J.R. Williams, and L. Yin. 2007. Test of APEX for nine forested watersheds in East Texas. J. Environ. Qual. 36:983-995.

Williams, J.R., A.D. Nicks, and J.G. Arnold. 1985. SWRRB, a simulator for water resources in rural basins. ASCE Hydr. J. 111:970-986.

Williams, J.R. 1995. The EPIC model. In computer models of watershed hydrology. p. 909-1000.In V.P. Singh, (Ed.).Computer models in watershed hydrology. Water Resources Publications, Highlands Ranch, CO.

Williams, J.R., J.G. Arnold, R. Srinivasan, and T.S. Ramanarayanan. 1998. APEX: A new tool for predicting the effects of climate on $\mathrm{CO} 2$ changes on erosion and water quality. NATO ASI Series 1:441-449.

Williams, J.R., W.L. Harman, M. Magre, U. Kizil, J.A. Lindley, G. Padmanabhan, and E. Wang. 2006. APEX feedlot water quality simulation. Trans. ASABE. 49:6173.

Williams, J.R., R.C. Izaurralde, and E.M. Steglich. 2008a. Agricultural policy/environmental extender model: User's manual version 0604. BREC Report \#2008-16. Blackland Research and Extension Center. p. 222. Available at http://epicapex.brc.tamus.edu/downloads/usermanuals. aspx. (verified on 5/28/2010).

Williams, J.R., R.C. Izaurralde, and E.M. Steglich. 2008b. Agricultural Policy/Environmental Extender model: Theoretical Documentation. Version 0604. BREC Report 2008-17. Temple,Tex.: Texas A\&M University, Texas AgriLIFE Research, BlacklandResearch and Extension Center. Available at 
http://epicapex.brc.tamus.edu/downloads/user-manuals. (verified on 28 May 2012).

Williams, J.R., N. Kannan, X. Wang, C. Santhi, J.G. Arnold. 2012. Evolution of the SCS runoff curve number method and its application to continuous runoff simulations. J Hydraul. Eng. 17:1221-1229. 
Table 3.1. Subarea parameters used to simulate crop areas and grass waterways of the three watersheds at the paired watershed study, Greenley Research Center, Missouri, USA.

\begin{tabular}{|c|c|c|}
\hline \multirow[t]{2}{*}{ Parameter $^{\dagger}$} & \multicolumn{2}{|c|}{ Subarea } \\
\hline & Crop & Grass waterway \\
\hline LUN-Land use number & 5 & 22 \\
\hline CHN-Manning's " $n$ ” for channel & 0.015 & 0.14 \\
\hline UPN-Manning's “n” for upland & 0.3 & 0.4 \\
\hline RCHN-Channels Manning's for routing reach) & 0.05 & 0.14 \\
\hline RCHC-USLE crop-management factor & 0.01 & 0.0001 \\
\hline RCHK-USLE erodibility factor & 0.3 & 0.2 \\
\hline
\end{tabular}


Table 3.2. Model parameters used in calibration, the range tested, selected values, and their sensitivity rank (1-highest sensitivity) on model outputs of the three watersheds at the paired watershed study, Greenley Research Center, Missouri, USA.

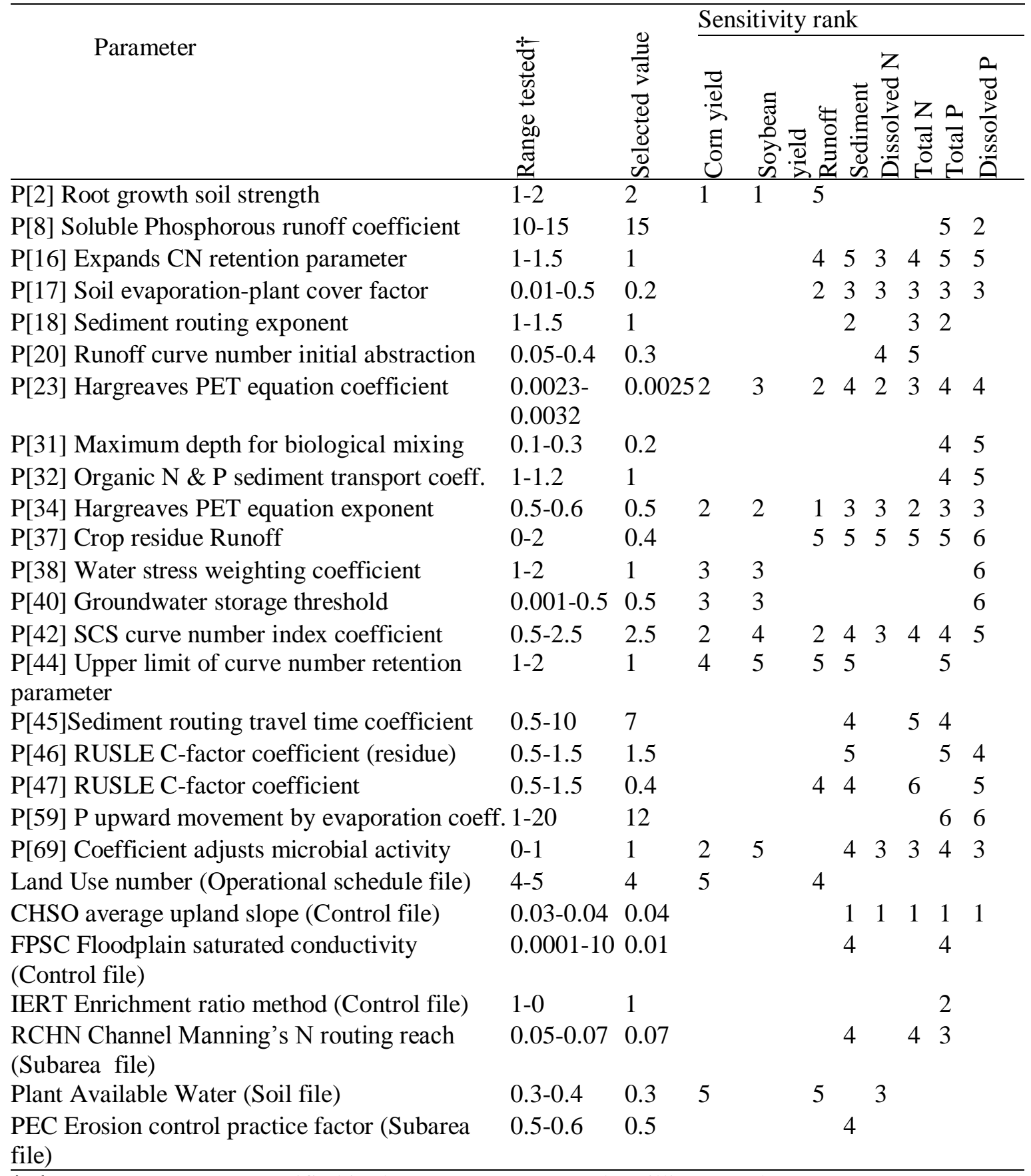

$\dagger$ The parameter ranges specified in the APEX user manual (Williams et al., 2008a) 
Table 3.3. Agricultural Policy Environmental Extender (APEX) model performance for coefficient of determination $\left(r^{2}\right)$ and Nash-Sutcliffe Coefficient (NSC) values for event-based runoff, sediment, total nitrogen (TN), and total phosphorus (TP) for Center, West, and East watersheds at Greenley Research Center, Missouri, USA for calibration and validation.

\begin{tabular}{|c|c|c|c|c|}
\hline Model & Model & Calibration & Validation & \\
\hline output & performance & Center & West & East \\
\hline \multirow{2}{*}{ Runoff } & $r^{2}$ & 0.94 & 0.91 & 0.93 \\
\hline & $\mathrm{NSC}$ & 0.84 & 0.80 & 0.87 \\
\hline \multirow{4}{*}{ Sediments } & Pbias & 3.66 & 25.78 & 19.24 \\
\hline & $r^{2}$ & $0.59^{\dagger}$ & $0.34^{\dagger}$ & $0.35^{\dagger}$ \\
\hline & NSC & $0.56^{\dagger}$ & $0.26^{\dagger}$ & $0.19^{\dagger}$ \\
\hline & Pbias & $-26.82^{\dagger}$ & $-52.12^{\dagger}$ & $-67.63^{\dagger}$ \\
\hline \multirow{2}{*}{$\mathrm{TN}$} & $r^{2}$ & $0.74^{\dagger}$ & $0.53^{\dagger}$ & $0.57^{\dagger}$ \\
\hline & NSC & $0.44^{\dagger}$ & $0.31^{\dagger}$ & $0.18^{\dagger}$ \\
\hline \multirow{4}{*}{$\mathrm{TP}$} & Pbias & $17.88^{\dagger}$ & $24.56^{\dagger}$ & $46.58^{\dagger}$ \\
\hline & $r^{2}$ & $0.87^{\dagger}$ & $0.80^{\dagger}$ & $0.78^{\dagger}$ \\
\hline & $\mathrm{NSC}$ & $0.67^{\dagger}$ & $0.78^{\dagger}$ & $0.32^{\dagger}$ \\
\hline & Pbias & $32.8^{\dagger}$ & $-7.18^{\dagger}$ & $-51.15 \dagger$ \\
\hline
\end{tabular}

${ }^{\dagger}$ Only for storm events 25 to 42 . 


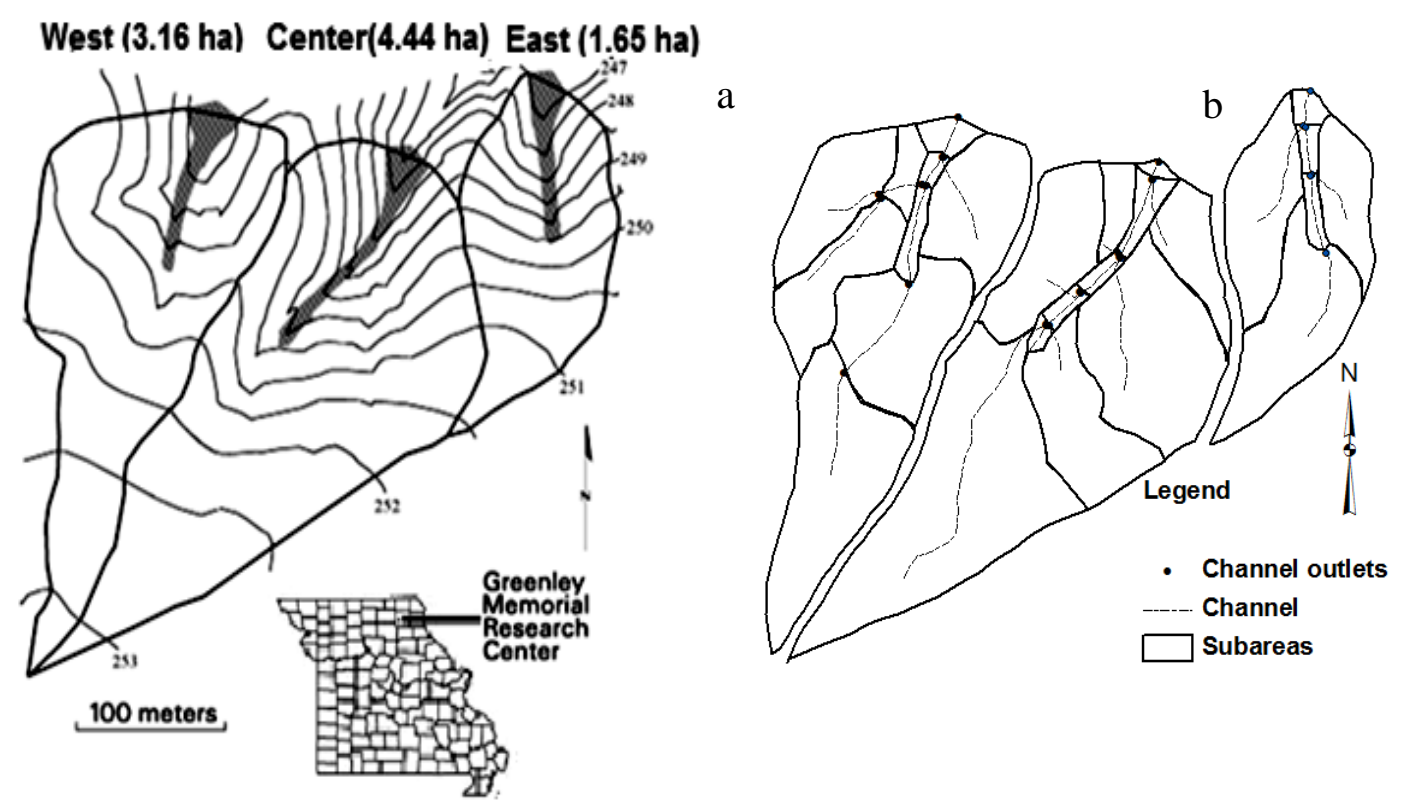

Fig. 3.1. Topographic map (0.5 m interval) of West, Center and East watersheds (a; After Udawatta et al., 2002). Grey lines represent contour lines (thin) and grass waterways (wide). The inset map shows the approximate location of the study site in Knox County, Missouri. ArcAPEX model delineated subareas and stream network of the three watersheds (b). 

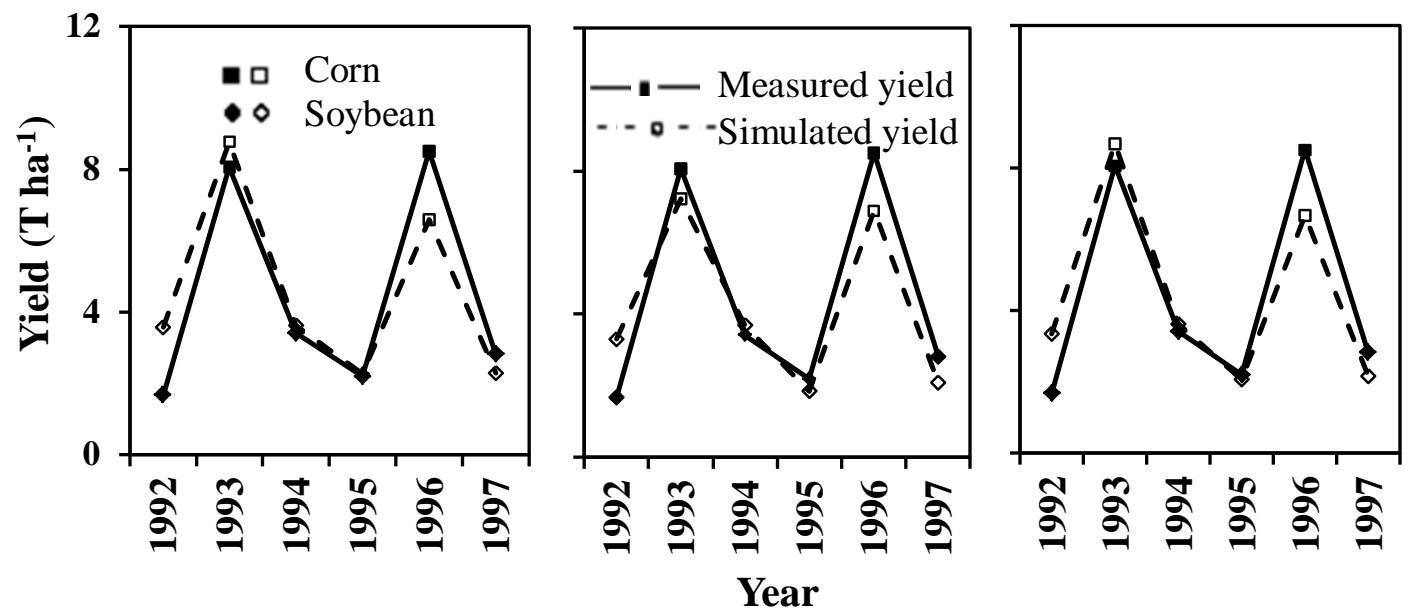

Fig. 3.2. Measured and simulated corn and soybean yields for Center (a), West (b), and East (c) watersheds during the study period at the paired watershed study, Greenley Research Center, Missouri, USA. 

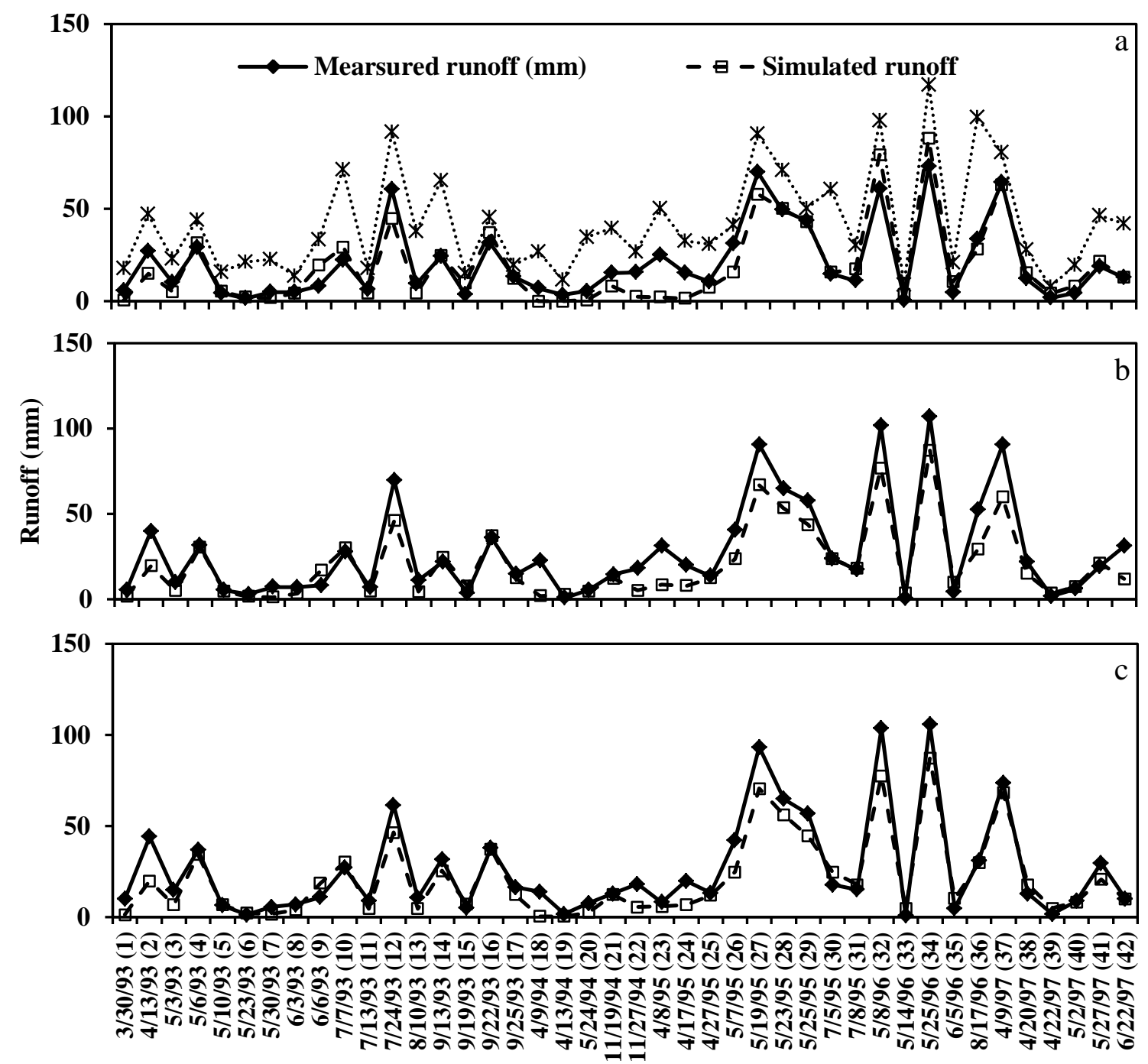

Storm events

Fig. 3.3. Measured and simulated runoff for Center (a), West (b), and East (c) watersheds during the study period at the paired watershed study, Greenley Research Center, Missouri, USA. The Center (a) watershed shows the results for calibration while West (b), and East (c) watersheds show the results for validation. Please note that the $\mathrm{X}$-axis values are independent events and are not continuous. 

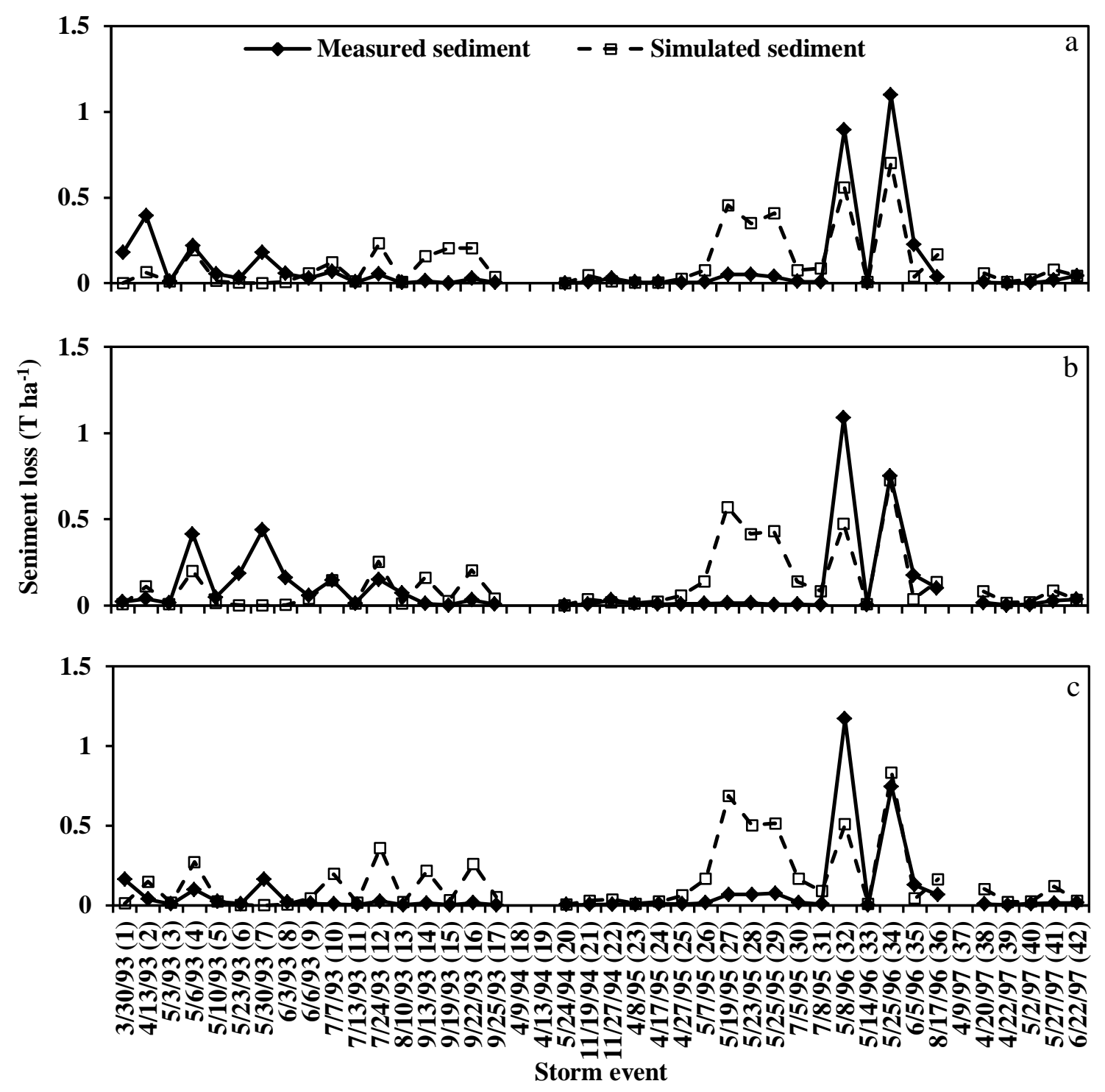

Fig. 3.4. Measured and simulated sediment losses for Center (a), West (b), and East (c) watersheds during the study period at the paired watershed study, Greenley Research Center, Missouri, USA. The Center (a) watershed shows the results for calibration while while West (b) and East (c) watersheds show the results for validation. Measured sediment losses for events 18, 19, and 37 were not available. Please note that the $\mathrm{X}$-axis values are independent events and are not continuous. 


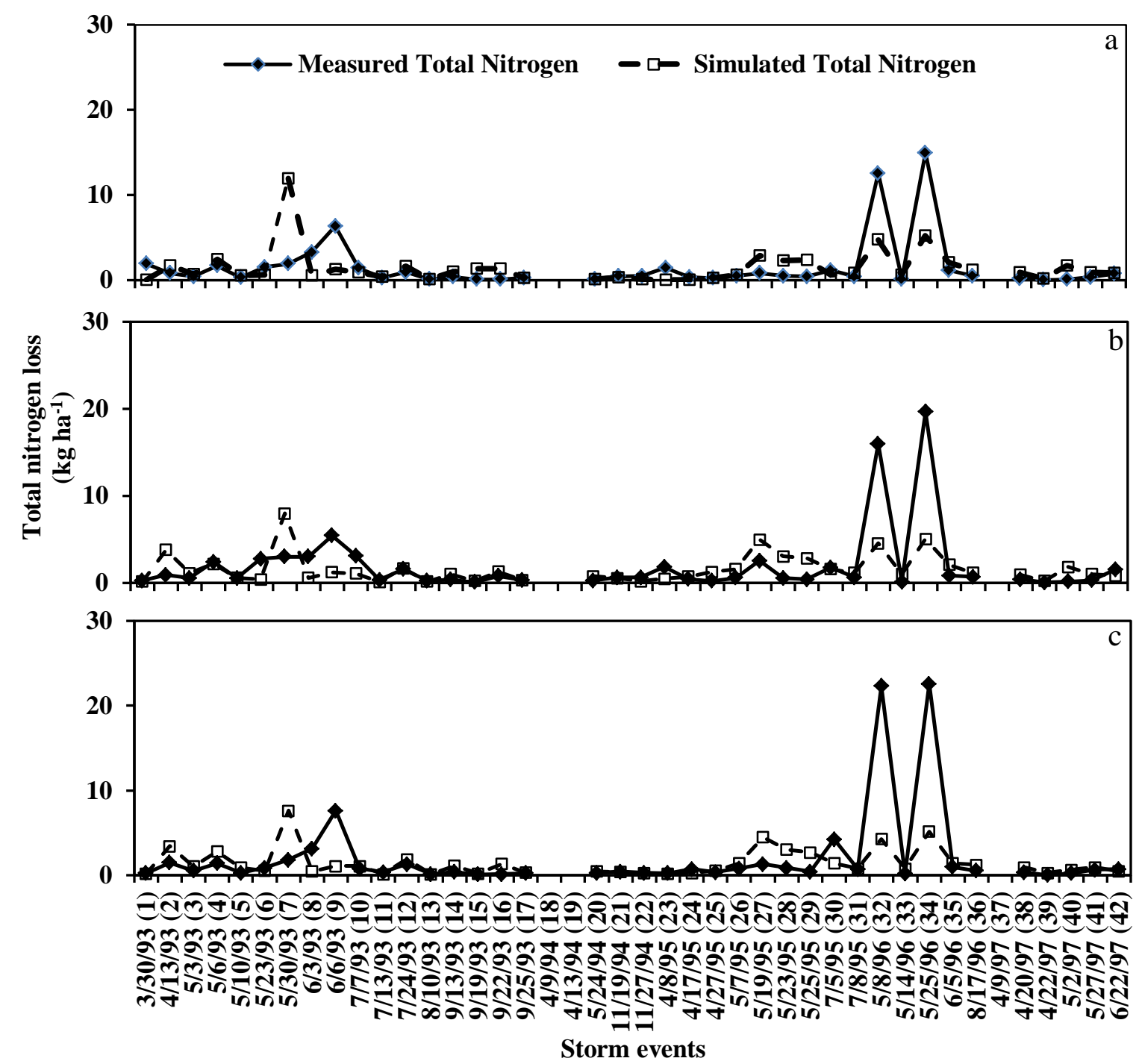

Fig. 3.5. Measured and simulated total nitrogen losses for Center (a), West (b), and East

(c) watersheds during the study period at the paired watershed study, Greenley Research

Center, Missouri, USA. The Center (a) watershed shows the results for calibration while

West (b) and East (c) watersheds show the results for validation. Measured total nitrogen losses for events 18, 19, and 37 were not available. Please note that the $\mathrm{X}$-axis values are independent events and are not continuous. 


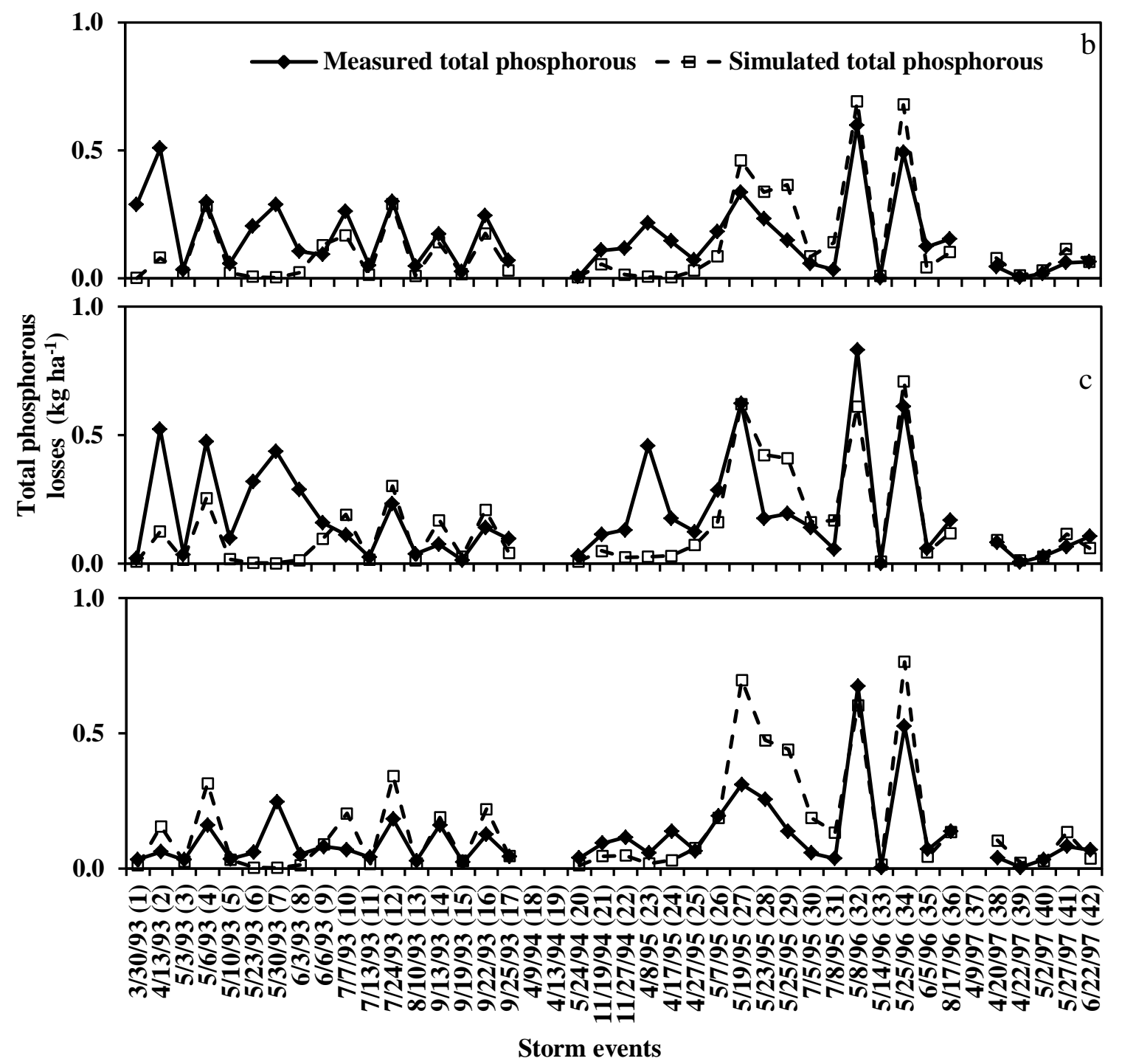

Fig. 3.6. Measured and simulated total phosphorous losses for Center (a), West (b), and

East (c) watersheds during the study period at the paired watershed study, Greenley

Research Center, Missouri, USA. The Center (a) watershed shows the results for calibration while West (b) and East (c) watersheds show the results for validation.

Measured total phosphorous losses for events 18, 19, and 37 were not available.

Please note that the $\mathrm{X}$-axis values are independent events and are not continuous. 

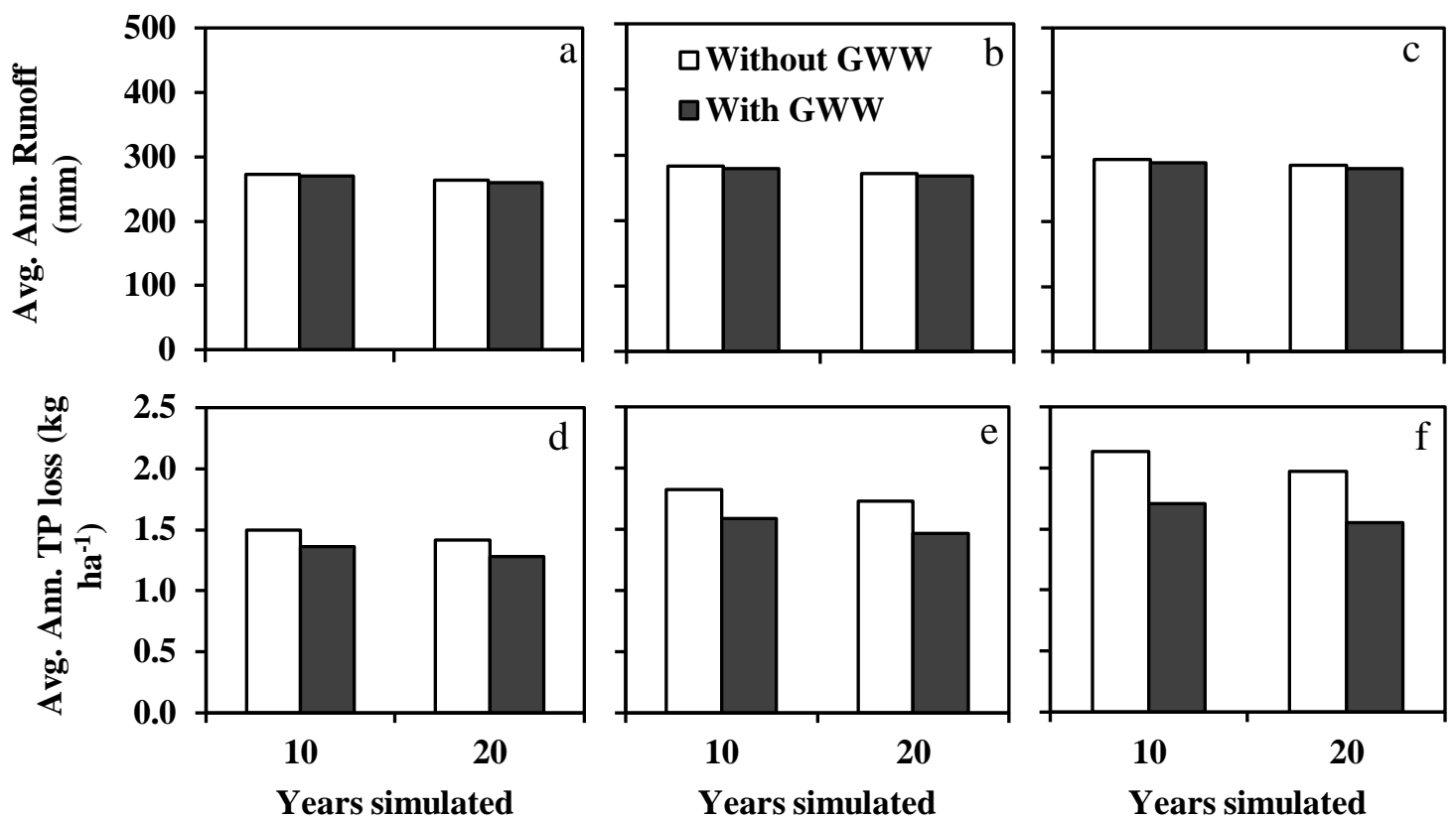

Fig. 3.7. APEX model predictions for average annual runoff, and average annual total phosphorous (TP) losses for Center (a and d), West (b and e), and East (c and f) watersheds, respectively, at the paired watershed study, Greenley Research Center, Missouri, USA, for 10 and 20 years, with and without grass waterways. 


\title{
4. CHAPTER
}

\section{APEX SIMULATION: ENVIRONMENTAL BENEFITS OF AGROFORESTRY AND GRASS BUFFERS FOR CORN- SOYBEAN WATERSHEDS}

\begin{abstract}
The Agricultural Policy Environmental Extender (APEX) model is used to simulate the effects of vegetative filter strips on runoff and pollutant loadings from agricultural watersheds. A long-term paired watershed study under corn (Zea mays L.)soybean [Glycine $\max (\mathrm{L}$.$) Merr.] rotation with agroforestry (grass+trees), and grass$ upland buffers (4.5 m width), in Northeast Missouri, has shown 11-35\% reduction in measured sediment and nutrient loads. The objective of this study was to calibrate and validate the APEX model for the study watersheds and find optimum buffer dimensions, placement locations, and effects of a winter cover crop. ArcAPEX and APEX0604 versions were used for the simulations. The simulated corn and soybean yields were within $\pm 13 \%$ and $\pm 27 \%$ of the measured yields, respectively, except for the validation by the grass buffer watershed. The agroforestry, grass buffer, and control watershed models were calibrated (1998 to 2001) and validated (2002 to 2008) for event-based runoff with $r^{2}$ and Nash-Sutcliffe Coefficients (NSC) values ranging 0.7-0.8 and 0.4-0.7, respectively. They were calibrated and validated for event-based total phosphorous (TP) with $r^{2}$ and NSC ranging 0.5-0.8 and 0.4-0.7, respectively. The models could not be
\end{abstract}


calibrated for sediment and total nitrogen. The simulated grass and agroforestry buffers reduced average event-based runoff by $5.2 \%$ and $4.3 \%$ and TP by $12.8 \%$ and $44.5 \%$, respectively. An increase in buffer widths to 5.5 and $7.5 \mathrm{~m}$ had no effect on runoff or TP loads. Placement of buffers in backslope positions appears to be effective in reducing runoff and TP loads in the agroforestry watershed. Simulation of a winter cover crop, winter wheat (Triticum hybernum), reduced TP loadings by $12 \%$ to $19 \%$. The calibrated and validated APEX model could be used to simulate upland contour agroforestry and grass buffers to determine environmental benefits of buffers.

Key words: Claypan soils, Non-point source pollution, Soil conservation, Upland contour vegetative buffers, Watershed modeling, Water quality,

\section{Introduction}

Degradation of water quality is a major environmental concern. Agricultural practices have been identified as the leading source of contaminants with sediment, nutrients and other agricultural pollutants contributing to the impairment of nearly $50 \%$ of rivers, streams and lakes in the U.S. (USEPA, 2010). The spatial scale of the sources and transport of these pollutants spans many variations of landscape scales, ranging from field plots to regional hydraulic systems (Capel et al., 2008). Because of this distributed nature, the term non-point source pollution (NPSP) is used to identify contaminants originating from agricultural lands. Although considerable research has been conducted at the field scale (Capel et al., 2008), understanding the processes at larger watershed scales with multiple land-use settings is lacking. In situ studies at the watershed scale 
have inherent problems such as high costs due to their large scale and complex nature, private ownership of land, and results not timely enough to avoid any negative consequences of current practices.

According to Sharpley et al. (2003), hydrologic models provide a convenient, efficient, and economically feasible method to evaluate nutrient loading mechanisms under various management systems provided sufficient measured data are available at the small watershed scale. Among many hydrologic models, the Agricultural Policy Environmental eXtender (APEX ) model has been widely tested and used to simulate complex combinations of farm level landscapes, cropping systems and land management practices such as filter-strips at both field and watershed scales (Williams et al., 2006; Tuppad et al., 2010; Gassman et al., 2010; Mudgal et al., 2012; Wang et al., 2012; Senaviratne et al., 2013). APEX is the multi-field version of the single field model, the Environmental Policy Integrated Climate (EPIC; Williams, 1990; Williams et al., 1998) which was developed to study environmental problems of livestock at a watershed scale. It is a distributed, continuous, daily time-step farm or small watershed-scale (up to 2500 km²; Williams et al., 2002; Gassman et al., 2005) hydrologic/water quality model and it allows simultaneous simulation of multiple subareas for a wide range of soil, landscape and management practices. Wang et al. (2012) present an update on the most recent research activities of the APEX model.

Agroforestry practices have been shown to improve water and soil quality and reduce NPSP losses from agricultural land (Abu-Zreig et al., 2003; Udawatta et al., 
2002). Agroforestry practices such as riparian buffers and upland contour filter strips placed adjacent to source areas have been quite effective in reducing sediment and nutrient yields from crop land (Lowrance et al., 1984; Dillaha et al., 1989; Schmitt et al., 1999; Liu et al., 2008; Schultz et al., 2009; Udawatta et al., 2002; 2011). Upland contour buffers, riparian buffers and grass waterways are permanent areas of vegetation designed to remove sediment and other pollutants from surface runoff, by filtration, deposition, and infiltration (Dillaha et al., 1989). The trapping efficiency of filter strips depends on the incoming load of sediment and nutrients and flow rate as well as grass height, density, and width of the strip (Dilliaha et al., 1989); degree of submergence, slope and soil texture (Dosskey et al., 2008). Liu et al. (2008) suggest that the slope and width are the major factors influencing the sediment trapping efficiency of buffers. Studies have revealed that a 4-4.5 m buffer width as the optimum for 2-9\% slopes (Robinson et al., 1996; Dillaha et al., 1989) and $7.5 \mathrm{~m}$ as the optimum buffer width for $6.5 \%$ slopes (Schmitt et al., 1999).

The present study used data from three adjacent, field-size, no-till corn-soybean watersheds at the Greenley Memorial Research Center, Knox County, Missouri monitored by Udawatta et al. (2011). About midway into the experiment, grass and agroforestry buffers were installed on two of the three watersheds. This paired watershed study showed $28-30 \%$ reductions in sediment, $11-13 \%$ reduction in total nitrogen $(\mathrm{TN})$, and $22-26 \%$ reductions in total phosphorous (TP) loads eleven years after the establishment of 4.5-m buffers (Udawatta et al., 2011). The goal of the current study was 
to determine the optimum buffer width and placement locations to make further recommendations on upland contour agroforestry and grass buffers. Sub-objectives were to: (1) calibrate and validate the APEX model for crop yields, runoff, sediment, TN, and TP for agroforestry, grass buffer and control watersheds, (2) use the calibrated and validated model to quantify NPSP reduction efficiencies of varying buffer widths and placement combinations, and (3) determine the effectiveness of cover crops on NPSP reduction.

\section{Materials and Methods}

\section{Watershed Characteristics}

Three adjacent north-facing no-till corn-soybean (Zea mays L.- Glycine max (L.)) watersheds (East-1.65 ha, Center-4.44 ha, and West-3.16 ha; Fig. 4.1a) were established and instrumented in early 1991, at the University of Missouri Greenley Memorial Research Center in Knox County, Missouri, USA (4001' N, 92 $11^{\prime}$ W; Udawatta et al., 2002). In 1997, 4.5-m [15 ft.] wide permanent contour grass-legume strips (CGS) consisting of redtop (Agrostis gigantean Roth), brome grass (Bromus spp.), and birdsfoot trefoil (Lotus corniculatus L.) were established at 36.5-m (at lower slope positions 22.8 m) apart in the West and Center watersheds. Along the center of the grass strips of the Center watershed, a tree line of pin oak (Quercus palustris Muenchh.), swamp white oak (Q. bicolor Willd.), and bur oak (Q. macrocarpa Michx.) were planted alternately at 3-m spacing to establish the agroforestry buffers (AGF). The East watershed was maintained as the control. 
Watersheds are located in the Central Claypan region (USDA-NRCS MLRA 113) with soils having a poorly drained argillic horizon known as a claypan, existing within 0.1 to $0.5 \mathrm{~m}$ of the surface, with an abrupt $100 \%$ increase of clay content than the layer above with clay content varying from 350-600-g kg-1 (Miles and Hammer, 1989). The claypan soils of the watersheds were: Putnam silt loam (fine, smectitic, mesic Vertic Albaqualf) along 0-1 \% slopes, Kilwinning silt loam (fine, smectitic, mesic Vertic Epiaqualf) along 2-5\% slopes, and Armstrong loam (fine, smectitic, mesic Aquertic Halpudalf) along 5-9\% slopes in minor portions of the watersheds. Mean annual precipitation (30-yr) is $920 \mathrm{~mm} \mathrm{yr}^{-1}$ with $66 \%$ occurring from April to September and obtained by daily measurement at the Novelty weather station (http://agebb.missouri.edu/) located within 500-m of the watershed. Average annual air temperature is $11.7^{\circ} \mathrm{C}$ with an average monthly low of $-6.6^{\circ} \mathrm{C}$ and high of $31.4^{\circ} \mathrm{C}$. Mean snowfall is $590 \mathrm{~mm}$ per year and stays on the ground for extended periods.

Grass waterways of each watershed consisted mainly of fescue grass [Schedonorus phoenix (Scop.) Holub] and directed flow towards a concrete approach structure and an H-flume. For flow measurement and sampling, ISCO (Lincoln, NE, USA) bubbler flow measuring devices and ISCO 3700 samplers were used. Flow based samples were collected from late February/early March to December each year. Composite samples by storm events were analyzed for sediments, TN, nitrate, and TP concentrations (Udawatta et al., 2002). Crop yields were determined by GPS yield data points, collected with an Ag Leader Technology 2000 (Ames, IA) yield monitor attached 
to the R50 Gleaner (AGCO Corp., Duluth, GA) combine for corn (5-m swath width) and soybean (5-m swath width) as described in Senaviratne et al. (2012). Grain yields were adjusted for moisture at 150 and $130 \mathrm{~g} \mathrm{~kg}^{-1}$ for corn and soybean, respectively, prior to yield comparisons.

\section{Simulating Watersheds with APEX}

The AGF, CGS and Control watersheds were custom delineated (Fig. 4.1b) using ArcAPEX and ArcGIS 9.3 software. The digital elevation models (created from $25-\mathrm{cm}$ contour survey maps), land use maps, soil maps, management information (Udawatta et al. 2002; 2006) and daily measured weather inputs of precipitation, maximum and minimum temperature, and solar radiation obtained from the Novelty weather station were used for the model simulations. The agroforestry and grass buffers, and grass waterways were specified as different subareas from the crop subareas (Table 4.1) and included perennial vegetation with relevant management practices. The input files created by ArcAPEX were manipulated to optimize the model for calibration using a text editor according to the guidelines provided in the APEX user manual (Williams et al., 2008) and the version APEX0604 was used for latter runs. Site specific soil data measured from 80 cores ( 1-m deep) available for the three watersheds were used to update the soils in the model. The details included depth to claypan, texture, cation exchange capacity, organic carbon content, and $\mathrm{pH}$. The saturated hydraulic conductivity $\left(\mathrm{K}_{\text {sat }}\right)$, field capacity, permanent wilting point, and bulk density were obtained from Seobi et al. (2005). 
The claypan was simulated in APEX as a separate layer specified in the soil files with relevant soil characteristics, i.e. depth to claypan $(25-65 \mathrm{~cm})$, thickness of argillic horizon (125-150 cm), clay content $(28-46 \%)$, bulk density $\left(1.20-1.45 \mathrm{Mg} \mathrm{m}^{-3}\right)$, and $\mathrm{K}_{\mathrm{sat}}$ (0.07-0.007 $\left.\mathrm{mm} \mathrm{h}^{-1}\right)$. APEX uses a storage routing technique applied layer by layer from the surface to the deepest layer. If water movement is restricted downward or laterally because of lower $\mathrm{K}_{\mathrm{sat}}$ in the deeper layer or of layer saturation, the excess water is transferred to the layer above. This approach was used to simulate claypan hydrology.

Crop growth is simulated until accumulated heat units (growing degree days) equal the potential heat units (PHU) for the crop based on the temperature from planting date to harvest date (Williams et al., 1998). The model is also capable of simulating mixed stands of up to ten crops or other plants species and accounts for the competitive effects among them for light, water, and nutrients (Gassman et al., 2010).

The model options of soil moisture index (SMI) based on continuous curve number (CN) method (SCS, 1985; Williams and LaSeur, 1976) was selected for runoff estimation in which, the retention parameter, $s$, is estimated based on soil moisture depletion which is a function of potential evapotranspiration (Williams et al., 2012). The modified rational method (Williams, 1995) of estimating peak runoff rate was selected for this study. The Hargreaves and Samani, (1985) method, which was found to be as efficient as Penman method, using only extra terrestrial radiation and air temperature (Oudin et al., 2005) was selected for estimating the potential evaporation. The Penman method also requires additional data such as wind speed and relative humidity, which 
were not available for the current study. The MUSS equation (small watershed version; Williams, 1995) for estimating soil erosion, which is a variant of the Modified Universal Soil Loss Equation (MUSLE; Williams, 1975), was selected for this study. MUSLE uses variable runoff instead of rainfall as in the Universal Soil Loss Equation (USLE; Wischmeier and Smith, 1978) as the driving force which was found to increase the accuracy of the estimation of erosion and sediment loss (Williams et al., 2006).

\section{Calibration and validation}

The APEX model was manually calibrated using the most sensitive parameters reported by Senaviratne et al. (2013) for the pre-buffer watersheds and the APEX user manual (Williams et al., 2008). The measured crop yields, event runoff, event losses of sediment, TN, and TP from the AGF and CGS buffers, and the Control watershed were used for calibration and validation of the APEX model. Crop yields and event runoff data of storm events (14 events) from 1998 to 2001 were used for the calibration and those storm events from 2002 to 2008 (21 events) were used for the validation of the model. The number of events for validation was increased to include higher rainfall events. Measured sediment and nutrient losses available for 11 storm events from 1998 to 2001 and 10 storm events from 2002 to 2008 were used for the calibration and validation, respectively, as the sediment and nutrient data were not available for all the events due to insufficient runoff volume for sampling and/or instrument errors.

The coefficients of determination $\left(r^{2}\right)$, Nash Sutcliffe coefficient (NSC; Nash and Sutcliffe, 1970) and percent bias (Pbias) were used to compare the model predictions 
against the measured outputs. The $r^{2}$ was used as an indicator of strength of the relationship. NSC measures the degree of model accuracy compared to the arithmetic average of the measured output. Both $r^{2}$ and NSC values of one indicate perfect prediction while values close to zero or negative (NSC values) indicate poor predictability. The Pbias measures the extent of the deviation between the predicted and measured values.

\section{Scenario Analysis}

The AGF and CGS watersheds were simulated with increased buffer widths of 5.5 $\mathrm{m}$ and $7.5 \mathrm{~m}$ to find the optimum width of the buffers. The models were also simulated to test the effects of buffers by 1) removing all buffers and 2) leaving the buffers only at selected landscape positions: summit, shoulder, back slope, and foot slope, to test the location effects on average annual runoff and average annual TP loadings. A winter cover crop, winter wheat, was planted one month before the harvest of the main crop and killed three weeks before the planting of the crops in the following spring. The model default winter wheat crop was used for the simulations.

\section{Results and Discussion}

\section{Crop yields}

The APEX model was calibrated and validated for corn and soybean yields with $r^{2}$ over 0.80 and NSC over 0.72 for AGF, CGS and Control watersheds except for the validation by the CGS watershed ( $r^{2} 0.68$ and NSC 0.42; Table 4.2). Pbias values were within $\pm 15 \%$ except for the validation. On the same watersheds, Senaviratne et al. (2013) 
reported crop yields within $\pm 13 \%$ of the measured yields from the period 1991 to 1997 . $\mathrm{Hu}$ et al. (2007) calibrated corn and soybean yields to be within -10 to $6 \%$ of measured yield for Soil and Water Assessment Tool model and Mudgal et al. (2012) calibrated the APEX model for crop yields to be within $\pm 9 \%$ of the measured yields. Proper calibration and validation of the model for crop yield is a requirement for proper simulation of the nutrient balances of the watersheds (Hu et al., 2007; Nair et al., 2011; Mudgal et al., 2012) and proper evaluation of management scenarios (Arnold et al., 2012).

Runoff

Figure 4.2 shows the APEX predicted and measured event-based runoff with the corresponding rainfall events of AGF (a), CGS (b) and Control (c) watersheds during the calibration and validation. The APEX model was well calibrated and validated for eventbased runoff of AGF, CGS and control watersheds with $r^{2}$ values ranging from 0.78 to 0.84 for calibration and 0.68 to 0.78 for validation (Table 4.2). NSC values ranged between 0.68 and 0.76 for calibration and 0.43 and 0.58 for validation for event-based runoff. Performance indicators for event-based runoff were better for the Control watershed model than for the other two. Pbias values were within $\pm 25 \%$ for all calibrations and validations of the watersheds. These goodness of fit values were highly satisfactory according to the specification given by Wang et al. (2012) for the APEX model. They have stated that $r^{2} \geq 0.60$ and Pbias within $25 \%$ are satisfactory for monthly flow calibrations of the APEX model and could be further relaxed for daily or eventbased simulations. The only other vegetative filter strips APEX applications for which 
model performance for runoff have been published are those by Flowers et al. (1996) for cropland, and Kumar et al. (2011) for grazed pasture. Flowers et al. (1996) used APEX model to simulate eight plot scale studies having crops with different treatments of dairy manure and crop / filter strip combinations on hay production operations (with limited grazing) which were monitored for cumulative runoff, sediment, and nutrients for 17 months. They found that the APEX model simulated overall cumulative runoff, sediment and nutrients satisfactorily. The study concluded that the model needs more improvements and a longer time period to make valid conclusions. Kumar et al. (2011) calibrated and validated the APEX model for event-runoff of small pasture watersheds with edge of the field agroforestry buffers with $r^{2}$ and NSC values over 0.5 .

Other studies have used the APEX model to simulate the effects of filter strips. Mudgal et al. (2012) used a calibrated and validated APEX model for a 35 ha field for event-based runoff ( $r^{2}$ values around 0.8 and NSC values around 0.7$)$ to identify critical management areas for water quality based on depth to claypan, slope, and saturated hydraulic conductivity. The identified critical management areas with corn-soybean rotation were simulated with warm season grasses to evaluate water quality differences. Williams et al. (2006) used the APEX model to simulate the effects of edge of field vegetative filter strips on annual losses of nutrients from feedlots and manure application fields in Texas, and Carrington, North Dakota. They found that the feedlots with lowest slopes, lowest annual rainfall, and filter strips with one to one filter flow length to feedlot flow length ratios had the maximum reduction of annual organic and soluble nitrogen and 
phosphorus losses. The reductions in runoff were not reported.

No study has calibrated and validated the APEX model for upland contour buffer strips in row-crop watersheds for event-based runoff with long-term data (10 years). Hence this study presents unique results obtained with the APEX model which has satisfactorily simulated the cropland, agroforestry and grass buffers, and grass waterways and their effects on event-based runoff with strong model performance coefficients for custom delineated watersheds, using long-term data for calibration and validation.

\section{Sediment}

Figures $3 \mathrm{a}, \mathrm{b}$, and c illustrate the measured and simulated event-based sediment loadings from AGF, CGS buffer, and Control watersheds, respectively. The model was not well calibrated for event-based sediment $\left(r^{2}\right.$ and NCS values $\left.<0.1\right)$ for the three watersheds. The model over-predicted the largest event on the $10^{\text {th }}$ of April 1999. Annual average sediment loss was within \pm 10 - $14 \%$ of the measured values when this over-predicted value was excluded. The APEX model study for the pre-buffer period reported that the model was calibrated for sediment only for events with larger than 50 mm rainfall (Senaviratne et al., 2013). They also reported the sediment depositions at the flume bed prior to the sampling point especially during low flow events, and thus measurements could have caused underrepresentation of larger sediment particles in the samples (Senaviratne et al., 2013). Mudgal et al. (2008) also reported similar sediment deposition at the weirs that affected the calibration of the APEX model for event-based sediment especially at low flow events. In-addition, they observed that event-based 
sediment values were over-predicted at high flow events.

The average measured event-based sediment loadings ranged from $0.0084 \mathrm{~T} \mathrm{ha}^{-1}$ from the AGF and CGS buffer watersheds to $0.0092 \mathrm{~T} \mathrm{ha}^{-1}$ from the Control watershed. The average measured sediment loadings for pre-buffer Center and CGS watersheds ranged between 0.099 to $0.1 \mathrm{~T} \mathrm{ha}^{-1}$ and that for the control was $0.0770 .1 \mathrm{~T} \mathrm{ha}^{-1}$. (Senaviratne, et al., 2013). Post buffer average sediment values were $88-95 \%$ less than the pre-buffer period (Senaviratne et al., 2013). The model simulated this reduction as 83-84\% for AGF and CGS buffer watersheds. These lower values of sediment in all three watersheds are in part explained by the dominance of low intensity rainfall events during the post-buffer period. However, Kumar et al. (2011) did not find a good calibration by the APEX model for sediment loss from pasture / agroforestry buffer watersheds mainly because of the low sediment concentrations. Additionally the longterm effects of buffers and grass waterways may have caused these reductions in sediment loadings.

Yin et al. (2009) were able to calibrate the APEX model for event-based sediments with model performance coefficients $r^{2}$ and NCS values over 0.5 and 0.4 , respectively. They collected the runoff water from a plot scale study in a series of sumps and tanks. In-order to get a representative sample, they agitated the water in the sumps before sampling and thus a better estimation of total sediment may have led to better calibration and validation of the model. Wang et al. (2007) found better APEX model calibration for monthly sediment loadings with $r^{2}$ and NCS values over 0.5 and 0.4 , 
respectively, for small forested watersheds instrumented with H-flumes. They had installed a sediment trap before the approach of the H-flume to measure the predepositing larger fraction of the sediment. Another study has calibrated the APEX model for yearly sediment to evaluate forestry best management systems (Saleh et al., 2004). Improved devices should be used that can trap total sediments when collecting samples at $\mathrm{H}$-flume or weir instrumentations. Another fact that may have affected the model calibration for event-based sediment may be that the model estimation is based on the MUSS equation which is a derivative of the USLE equation originally developed for annual soil erosion predictions (Merritt et al., 2003).

\section{Total Phosphorous}

A fewer number of event-based TP values were available for the calibration and validation of the model. However, the APEX model simulated event-based TP reasonably close to the measured values for the three watersheds (Figs. 4a, b, and c). Both $r^{2}$ and NSC values for calibration of the model for event TP were over 0.5 and Pbias values varied from \pm 18 to $41 \%$ for the three watersheds (Table 4.2 ). The $r^{2}$ values were over 0.5 and NSC values were over 0.4 (except for the Control watershed) for validation by the model for event-based TP. The Pbias values varied from \pm 15 to $44 \%$ for validation of the model by the three watersheds. The goodness of fitness values for monthly nutrient loading for the APEX model recommended by Wang et al. (2012) are $r^{2}>0.6$, NSC $>0.5$, and Pbias $<50 \%$. Hence the current model performances for eventbased TP were highly satisfactory. The reason for better calibration for TP than sediment 
was that TP is mostly associated with finer clay particles (Dillaha et al., 1989; Dorioz et al., 2006). The finer clay particles remain in suspension for a longer duration of time, thus making them better represented in the samples than larger sediment particles.

Therefore, the measured TP may have been better estimated than the sediments leading to better model calibration and validation.

\section{Total nitrogen}

The APEX model simulated event-based TN values were not consistent with the measured values for all three watersheds during calibration and validation as shown in Figs. 5a, b, and c. The goodness of fit model performance coefficients were less than 0.1 for all watersheds. The events 27 to 29 in the year 2004 have recorded an unusually excess amount of measured TN which could not be explained either by increase in runoff nor sediments during those events. It may have resulted due to measurement errors; thus these errors may also have contributed to poor calibration. It was also observed that the model predictions were too low for moderately high measured TN loadings (events 5, 18 to 22) and high for low measured TN loading (events (2, 3 and 4). However, the model predicted annual averages of TN within $\pm 27 \%$ of the measured annual averages of $\mathrm{TN}$ for all three watersheds. Wang et al. (2007) also reported that APEX did not simulate the monthly or yearly $\mathrm{N}$ losses as affected by clear-cut treatment of forest management.

\section{Scenario analysis}

Buffer width and placement of buffers

The calibrated and validated APEX model for AGF and CGS watersheds were 
simulated with expanded buffer widths from $4.5 \mathrm{~m}$ to 5.5 and $7.5 \mathrm{~m}$. The results indicate no significant reduction in average annual runoff or TP (Figs. 6a and b). Studies have found diminishing return in pollutant filtration with an increase in buffer width (Dillaha et al, 1989; Robinson et al., 1996; Schmitt et al., 1999). Some studies indicate that increasing buffer width beyond four to seven meters produces marginal increases in NPSP removal in runoff (Robinson et al., 1996; Schmitt et al., 1999). A review on vegetative filter strips by Liu et al. (2008) revealed that the efficiency of a particular buffer width mainly depends on the slope of the land. Studies have revealed that $4-4.5 \mathrm{~m}$ as the optimum buffer width for slopes around 2-9\% (Robinson et al., 1996; Dillaha et al., 1989) and $7.5 \mathrm{~m}$ as the optimum buffer width for slopes around 6.5\% (Schmitt et al., 1999). The results from the current study also revealed that the increase of buffer width from $4.5 \mathrm{~m}$ to 5.5 and $7.5 \mathrm{~m}$ marginally reduced runoff and TP loadings. The average slopes of the AGF, CGS, and Control watersheds were $1.3 \%, 0.9 \%$, and $2.1 \%$, respectively (Udawatta et al., 2004).

The simulated AGF and CGS buffer did not reduce average annual runoff but showed $4.3 \%$ and $5.2 \%$ respective reductions compared to non-buffer simulations (Fig. 4.7). The buffers at the shoulder and back slope positions contributed to the highest reductions in runoff in AGF (1.7\%) and CGS (2.4\%) buffer watersheds (Fig. 4.7a).

The TP loadings were reduced by $44.5 \%$ by the presence of the CGS buffers compared to the non-buffer simulations (Fig. 4.7b). The corresponding reduction in TP in the AGF buffer watershed was $12.8 \%$. The measured reductions in TP loadings were 
$22 \%$ and $26 \%$ by CGS and AGF buffers (Udawatta et al., 2011). The model has underpredicted TP loss reductions for AGF buffers and over-predicted values for CGS buffers. However in both buffers, grasses may have contributed to the filtration process of sediment whereas trees would have contributed by improving infiltration via the old root channels. Rose et al. (2003) have stated that the grass in buffers acts as a filter by increasing surface roughness thereby improving infiltration and reducing the flow velocity and volume. The diminution of transport capacity for solid particles in the flow leads to progressive sedimentation and trapping of sediment in the grass buffers (Dorioz et al., 2006). According to Dorios et al. (2006), the process of removal of finer clay particles differs from the deposition of the larger particles. The process of removal of finer clay particles resembles a process of several micro-centrifugations as the turbulent flow passes through the leafy matrix of the grass in the buffer zone. This process is termed turbulent filtration which mostly occurs within a certain distance in the buffer when the water velocity is attenuated to the required rate. As particulate $\mathrm{P}$ is predominantly held in the finer clay fraction of the sediment, a higher reduction of TP loadings in the grass strip may be attributed to higher turbulent filtration by the CGS buffers compared to AGF buffers. Another reason that may have been contributed to lower filtration by AGF was the weed mats around the trees $(1 \times 1 \mathrm{~m})$ and lower grass density.

The specific placement of CGS buffers on the shoulder or backslope positions of the watersheds had no effect on TP load reductions (Fig. 4.7). However, the AGF buffers 
at the shoulder and backslope positions of the watersheds contributed to the majority of $(8 \%)$ reductions by all the buffers $(13 \%)$. In other words, $62 \%$ of the total reductions were by the buffers placed at shoulder and backslope positions of the AGF watersheds.

\section{Winter cover crop}

The introduction of a winter cover crop, winter wheat (Triticum hybernum), did not reduce average annual runoff significantly but reduced average annual TP loadings by $15 \%, 24 \%$, and $22 \%$ in AGF, CGS, and Control watersheds, respectively. Udawatta et al. $(2004,2006)$ found that nearly $50 \%$ TP and TN losses occurred during the fallow periods, before the crops were planted and after the harvest conducted on the same watersheds. Results of the simulations agree with these findings by showing similar reductions in TP losses occurred with the winter cover crop. Cover crops provide ground cover to protect soil from raindrop impact and subsequent erosion. They also reduce nutrient leaching by utilizing nutrients for plant growth. Dabney (1998) reviewed several studies on the multitude of benefits of having cover crops during fallow periods. The review emphasized the need to address issues related to cost of establishment and management, and also adverse effects on the cash crop due to the depleted nutrient state caused by an excessive reduction in nutrients or allelopathic reactions.

\section{Conclusions}

The APEX model was reasonably calibrated and validated for crop yield, eventbased runoff and event-based TP loadings of the long-term monitored study watersheds located at the Greenley Memorial Research Center, in Northeast Missouri, with upland 
contour agroforestry and grass buffers, and a control treatment. The $r^{2}$ and NSC values were over 0.5 for runoff and TP for calibration and they were over 0.4 for validation. The model was not calibrated well for event-based sediment and TN probably due to low concentrations as a result of the buffers as well as low intensity rainfall events during the study periods. Underestimation of larger particles in the measured samples due to sedimentation on flume beds prior to the sampling point may also have affected sediment calibration results. The long-term scenario analysis of a buffer width increase from 4.5 to $5.5 \mathrm{~m}$ and $7.5 \mathrm{~m}$ showed no significant reduction in TP loads. The long-term scenario analysis showed 4.3 to $5.2 \%$ reductions in average annual runoff and 12.5 to $44.5 \%$ reduction in average annual TP loadings due to the presence of buffers. Higher reduction values for both annual runoff and TP loadings were obtained for the CGS buffer watershed. The buffers at the shoulder and back slopes of the landscape of the AGF watershed contributed to $62 \%$ of the total reduction of TP by the buffers. Simulation of a winter cover crop contributed to further reduction in annual TP by $15-24 \%$. The results of this unique study demonstrated that the APEX can be used to evaluate environmental benefits of upland filter strips and winter cover crops, provided sufficient long-term data are available for calibration and validation.

\section{Acknowledgements}

This work was funded through the University of Missouri Center for Agroforestry under cooperative agreements 58-6227-1-004 with the USDA-ARS. Any opinions, findings, conclusions or recommendations expressed in this publication are those of the 
authors and do not necessarily reflect the view of the U.S. Department of Agriculture.

\section{List of References.}

Abu-Zreig, M., R.P. Rudra, H.R. Whiteley, M.N. Lalonde, and N.K. Kaushik. 2003. Phosphorus removal in vegetated filter strips. J. Environ. Qual. 32: 613-619.

Arnold, J.G., D.N. Moriasi, P.W. Gassman, K.C. Abbaspour, M.J. White, R. Srinivasan, C. Santhi, R.D. Harmel, A. van Griensven, and M.W. Van Liew. 2012. SWAT: Model Use, Calibration, and Validation. Trans. ASABE 55(4): 1494-1508.

Capel, P.D., K.A. McCarthy, and J.E. Barbash. 2008. National, Holistic, Watershed-Scale Approach to Understand the Sources, Transport, and Fate of Agricultural Chemicals. J. Environ. Qual. 37(3): 983.

Dabney, S.M. 1998. Cover crop impacts on watershed hydrology. J. Soil Water Conserv. 53(3): 207-213.

Dillaha, T.A., R.B. Renear, S. Mostaghimi, and D. Lee. 1989. Vegetative filter strips for agricultural nonpoint source pollution control. Trans. ASAE. 32: 513-519.

Dorioz, J.M., D. Wang, J. Poulenard, and D. Trevisan. 2006. The effect of grass buffer strips on phosphorus dynamics - a critical review and synthesis as a basis for application in agricultural landscapes in France. Agric. Ecosyst. Environ. 117(1): 4-21.

Dosskey, M.G., M.J. Helmers, and D.E. Eisenhauer. 2008. A design aid for determining width of filter strips. J. Soil Water Conserv. 63(4): 232-241.

Fiener, P., and K. Auerswald. 2006. Seasonal variation of grassed waterway effectiveness in reducing runoff and sediment delivery from agricultural watersheds in temperate Europe. Soil Till. Res. 87(1): 48-58.

Gassman, P.W., J.R. Williams, V.W. Benson, R.C. Izaurralde, L.M. Hauck, C.A. Jones, J.D. Atwood, J.R. Kiniry, and J.D. Flowers. 2005. Historical development and applications of the EPIC and APEX models. Center for Agricultural and Rural Development, Iowa State University.

Gassman, P.W., J.R. Williams, X. Wang, A. Saleh, E. Osei, L.M. Hauck, R.C. Izaurralde, and J.D. Flowers. 2010. Invited reviewarticle: The Agricultural

Policy/Environmental eXtender model: An emerging tool for landscape and watershed environmental analysis. Trans. AS AE. 53(3): 711-740. 
Hargreaves, G.H., and Z.A. Samani. 1985. Reference crop evapo-transpiration from temperature. Applied Eng. Agric. 1: 96-99.

Hu, X., G.F. McIsaac, M.B. David, and C.A.L. Louwers. 2007. Modeling Riverine Nitrate Export from an East-Central Illinois Watershed Using SWAT. J. Environ. Qual. 36(4): 996-1005.

Liu, X., X. Zhang, and M. Zhang. 2008. Major factors influencing the efficacy of vegetated buffers on sediment trapping: A review and analysis. J. Environ. Qual. 37(5): 1667-1674.

Lowrance, R.R., R.L. Todd, J. Fail, O. Hendrickson, R. Leonard, and L.E. Asmussen. 1984. Riparian forests as nutrient filters in agricultural watersheds. J. Biosci. 34: 374-377.

Merritt, W.S., R.A. Letcher, and A.J. Jakeman. 2003. A review of erosion and sediment transport models. Environ. Model. Softw. 18(8-9): 761-799.

Miles, R.J., and R.D. Hammer. 1989. One hundred years of Sanborn field: Soil baseline data. p. 100-108. In Proceedings of the Sanborn Field Centennial. J.R. Brown (Ed.). University of Missouri. Columbia. MO.

Mudgal, A., C. Baffaut, S.H. Anderson, E.J. Sadler, and A.L. Thompson. 2008. APEX model assessment of variable landscapes on runoff and dissolved herbicides. In ASABE International Meeting, June.

Mudgal, A., C. Baffaut, S.H. Anderson, E.J. Sadler, N.R. Kitchen, K.A. Sudduth, and R.N. Lerch. 2012. Using the Agricultural Policy/Environmental eXtender to develop and validate physically based indices for the delineation of critical management areas. J. Soil Water Conserv. 67(4): 284-299.

Nair, S.S., K.W. King, J.D. Witter, B.L. Sohngen, and N.R. Fausey. 2011. Importance of Crop Yield in Calibrating Watershed Water Quality Simulation Tools1. J. Am. Water Resour. As. 47(6): 1285-1297.

Nash, J.E., and J.V. Sutcliffe. 1970. River flow forecasting through conceptual models part I - A discussion of principles. J. Hydrol. 10(3): 282-290.

Oudin, L., F. Hervieu, C. Michel, C. Perrin, V. Andréassian, F. Anctil, and C. Loumagne. 2005. Which potential evapotranspiration input for a lumped rain-runoff model? Part 2 - Towards a simple and efficient potential evapotranspiration model for rainfall-runoff modelling. J. Hydrol. 303: 290-306.

Robinson, C.A., M. Ghaffarzaddeh, and R.M. Cruse. 1996. Vegetative filter strip effects 
on sediment concentration in cropland runoff. J. Soil Water Conserv. 50: 227230.

Rose, C.W., B. Yu, W.L. Hogarth, A.E.A. Okom, and H. Ghadiri. 2003. Sediment deposition from flow at low gradients into a buffer strip - a critical test of reentrainment theory. J. Hydrol. 280(1-4): 33-51.

Saleh, A., J.R. Williams, J.C. Wood, L.M. Hauck, and W.H. Blackburn. 2004. Application of APEX for forestry. Available at http://ddr.nal.usda.gov/handle/10113/9677 (verified 29 January 2013).

Schmitt, T.J., M.G. Dosskey, and K.D. Hoagland. 1999. Filter strip performance and processes for different vegetation, widths, and contaminants. J. Environ. Qual. 28(5): 1479-1489.

Schultz, R.C., T.M. Isenhart, J.P. Colletti, W.W. Simpkins, R.P. Udawatta, and P.L. Schultz. 2009. Riparian and upland buffer practices. p. 163-217. In North American agroforestry: An integrated science and practice. H. E. Garrett (ed.). ASA, Madison, WI.

Senaviratne, G., R.P. Udawatta, K.A. Nelson, K. Shannon, and S. Jose. 2012. Temporal and Spatial Influence of Perennial Upland Buffers on Corn and Soybean Yields. Agron. J. 104(5): 1356-1362.

Senaviratne, G.M.M.. A., R.P. Udawatta, C. Baffaut, and S.H. Anderson. 2013. Agriculture Policy Environmental eXtender simulation of three adjacent row-crop watersheds in the claypan region. J. Environ. Qual. 42: 726-736.

Seobi, T., S.H. Anderson, R.P. Udawatta, and C.J. Gantzer. 2005. Influence of grass and agroforestry buffer strips on soil hydraulic properties for an Albaqualf. Soil Sci. Soc. Am. J. 69(3): 893-901.

Sharpley, A.N., J.L. Weld, D.B. Beegle, P.J.A. Kleinman, W.J. Gburek, P.A. Moore Jr., and G. Mullins. 2003. Development of phosphorus indices for nutrient management planning strategies in the United States. J. Soil Water Conserv. 58: $137-152$.

Tuppad, P., C. Santhi, X. Wang, J.R. Williams, R. Srinivasan, and P.H. Gowda. 2010. Simulation of conservation practices using the APEX model. Appl. Eng. in Agric. 26(5): 779-794.

Udawatta, R.P., J.J. Krstansky, G.S. Henderson, and H.E. Garrett. 2002. Agroforestry practices, runoff, and nutrient loss. J. Environ. Qual. 31(4): 1214-1225. 
Udawatta, R.P., P.P. Motavalli, and H.E. Garrett. 2004. Phosphorus loss and runoff characteristics in three adjacent agricultural watersheds with claypan soils. J. Environ. Qual. 33(5): 1709-1719.

Udawatta, R.P., P.P. Motavalli, H.E. Garrett, and J.J. Krstansky. 2006. Nitrogen losses in runoff from three adjacent agricultural watersheds with claypan soils. Agric. Ecosyst. Environ. 117(1): 39-48.

Udawatta, R.P., H.E. Garrett, and R. Kallenbach. 2011. Agroforestry buffers for nonpoint source pollution reductions from agricultural watersheds. J. Environ. Qual. 40(3): 800-806.

USEPA, (U.S. Environmental Protection Agency). 2010. Water quality assessment and total maximum daily loads information: National summery of state information. Available at http://iaspub.epa.gov/waters10/attains_nation_cy.control (verified 28 May 2012).

Wang, X., A. Saleh, M.W. McBroom, J.R. Williams, and L. Yin. 2007. Test of APEX for Nine Forested Watersheds in East Texas. J. Environ. Qual. 36(4): 983-995.

Wang, X., J.R. Williams, P.W. Gassman, C. Baffaut, R.C. Izaurralde, J. Jeong, and J.R. Kiniry. 2012. EPIC and APEX: Model use, calibration, and validation. Trans. ASABE. 55(4): 1447-1462.

Williams, J.R. 1975. Sediment routing for agricultural watersheds. Water Resour. Bull. 11: 965-974.

Williams, J.R., and W.V. LaSeur. 1976. Water yield model using SCS curve numbers. J. Hydraulics Div., ASCE. 102: 1241-1253.

Williams, J.R. 1990. The Erosion-Productivity Impact Calculator (EPIC) Model: A Case History. Phil. Trans. R. Soc. Lond. B 329: 421-428.

Williams, J.R. 1995. The EPIC model. p. 909-1000. In Computer models in watershed hydrology. V.P. Singh (ed.). Water Resources Publications, Highlands Ranch, $\mathrm{CO}$.

Williams, J.R., J.G. Arnold, R. Srinivasan, and T.S. Ramanarayanan. 1998. APEX: A new tool for predicting the effects of climate and $\mathrm{CO} 2$ changes on erosion and water quality. NATO ASI Series 1: 441-449.

Williams, J.R., J.G. Arnold, and R. Srinivasan. 2002. The APEX Model, BRC Report No. 00-06. Texas Agricultural Experiment Station, Blackland Research Center, Temple, TX. 
Williams, J.R., W.L. Harman, M. Magre, U. Kizil, J.A. Lindley, G. Padmanabhan, and E. Wang. 2006. APEX feedlot water quality simulation. Trans. ASABE. 49(1): 6173.

Williams, J.R., R.C. Izaurralde, and E.M. Steglich. 2008. Agricultural policy/environmental extender model: User's manual version 0604. BREC Report \#2008-16. Blackland Research and Extension Center. p. 222. Available at http://epicapex.brc.tamus.edu/downloads/usermanuals.aspx. (verified 12 June 2012).

Williams, J., N. Kannan, X. Wang, C. Santhi, and J.G. Arnold. 2012. Evolution of the SCS Runoff Curve Number Method and Its Application to Continuous Runoff Simulation. J. Hydraul. Eng. 17: 1221-1229.

Wischmeier, W.H., and D.D. Smith. 1978. Predicting rainfall erosion losses, a guide to conservation planning. Hand book No. 573. United States Department of Agriculture, Agricultural Experiment Station, Purdue.

Yin, L., X. Wang, J. Pan, and P.W. Gassman. 2009. Evaluation of APEX for daily runoff and sediment yield from three plots in the Middle Huaihe River Watershed, China. Trans. ASABE. 52(6): 1833-1845. 
Table 4.1. Subarea parameters used to simulate crop land, buffers, and grass waterways of the three watersheds at the paired watershed study, Greenley Research Center, Missouri, USA.

\begin{tabular}{|c|c|c|c|c|}
\hline Parameter & Crop & $\begin{array}{l}\text { Agroforestry } \\
\text { buffer }\end{array}$ & Grass buffer & $\begin{array}{l}\text { Grass } \\
\text { waterway }\end{array}$ \\
\hline LUN-Land use number ${ }^{\dagger}$ & 5 & 25 & 25 & 22 \\
\hline $\begin{array}{l}\text { CHN-Manning’s " } n \text { ” } \\
\text { for channel }\end{array}$ & 0.015 & 0.14 & 0.14 & 0.14 \\
\hline $\begin{array}{l}\text { UPN-Manning's “ } n \text { ” } \\
\text { for upland }{ }^{\ddagger}\end{array}$ & 0.3 & 0.4 & 0.4 & 0.4 \\
\hline $\begin{array}{l}\text { RCHN-Channels } \\
\text { Manning's for routing } \\
\text { reach) }{ }^{\ddagger}\end{array}$ & 0.05 & 0.14 & 0.14 & 0.14 \\
\hline $\begin{array}{l}\text { RCHC-USLE crop- } \\
\text { management factor }^{\ddagger}\end{array}$ & 0.01 & 0.0001 & 0.0001 & 0.0001 \\
\hline $\begin{array}{l}\text { RCHK-USLE } \\
\text { erodibility factor }{ }^{\ddagger}\end{array}$ & 0.3 & 0.2 & 0.2 & 0.2 \\
\hline Filter Strip Code ${ }^{\ddagger}$ & 0 & 1 & 1 & 0 \\
\hline $\begin{array}{l}\text { FFPQ fraction of } \\
\text { floodplain } \text { flow }^{\ddagger}\end{array}$ & & $\begin{array}{l}0.5-0.8 \\
\text { (depending on } \\
\text { the buffer }\end{array}$ & $\begin{array}{l}0.5-0.8 \\
\text { (depending on } \\
\text { the buffer }\end{array}$ & \\
\hline $\begin{array}{l}\text { RFPW Buffer } \\
\text { / Floodplain width }\end{array}$ & & $\begin{array}{l}\text { (Drainage area } \\
* 10000) /(\text { Flood } \\
\text { plain length } \\
* 1000)\end{array}$ & $\begin{array}{l}\text { (Drainage area } \\
* 10000) /(\text { Flood } \\
\text { plain length } \\
* 1000)\end{array}$ & \\
\hline $\begin{array}{l}\text { RFPL Buffer / } \\
\text { Floodplain length }^{\ddagger}\end{array}$ & & $\begin{array}{l}\text { Buffer/Flood } \\
\text { plain in } \mathrm{km}\end{array}$ & $\begin{array}{l}\text { Buffer/Flood } \\
\text { plain in } \mathrm{km}\end{array}$ & \\
\hline
\end{tabular}


Table 4.2. Agricultural Policy Environmental Extender (APEX) model performance for coefficient of determination $\left(r^{2}\right)$ and Nash-Sutcliffe Coefficient(NSC) values for crop yield, event runoff and total phosphorus (TP) for agroforestry buffer, contour grass buffer, and control watersheds at Greenley Research Center, Missouri, USA for calibration (crop yields: 1998 to 2002; runoff and TP: events 1 to 14) and validation (crop yields: 2003 to 2008; runoff, sediments, TN, and TP: events 15 to 35).

\begin{tabular}{|c|c|c|c|c|c|}
\hline \multicolumn{2}{|c|}{ Model output } & $\begin{array}{l}\text { Model } \\
\text { performance }\end{array}$ & $\begin{array}{l}\text { Agroforestry } \\
\text { buffer }\end{array}$ & $\begin{array}{l}\text { Contour grass } \\
\text { buffer }\end{array}$ & Control \\
\hline \multirow{6}{*}{$\begin{array}{l}\text { Crop } \\
\text { yield }\end{array}$} & \multirow{3}{*}{ Calibration } & $r^{2}$ & 0.96 & 0.97 & 0.99 \\
\hline & & NSC & 0.88 & 0.89 & 0.98 \\
\hline & & Pbias & 15.42 & -15.91 & 0.89 \\
\hline & \multirow{3}{*}{ Validation } & $r^{2}$ & 0.88 & 0.68 & 0.80 \\
\hline & & NSC & 0.77 & 0.42 & 0.72 \\
\hline & & Pbias & 15.48 & 22.45 & -4.38 \\
\hline \multirow{6}{*}{ Runoff } & \multirow{4}{*}{ Calibration } & $r^{2}$ & 0.78 & 0.84 & 0.80 \\
\hline & & NSC & 0.68 & 0.75 & 0.76 \\
\hline & & Pbias & 10.98 & -22.58 & 22.63 \\
\hline & & $r^{2}$ & 0.68 & 0.73 & 0.78 \\
\hline & \multirow[t]{2}{*}{ Validation } & NSC & 0.58 & 0.51 & 0.43 \\
\hline & & Pbias & 5.06 & -23.65 & 25.85 \\
\hline \multirow{6}{*}{ TP } & \multirow{4}{*}{ Calibration } & $r^{2}$ & 0.90 & 0.74 & 0.83 \\
\hline & & NSC & 0.79 & 0.50 & 0.70 \\
\hline & & Pbias & 32.52 & 18.22 & 41.25 \\
\hline & & $r^{2}$ & 0.57 & 0.50 & 0.57 \\
\hline & \multirow[t]{2}{*}{ Validation } & NSC & 0.52 & 0.42 & 0.37 \\
\hline & & Pbias & -16.02 & 15.71 & 44.19 \\
\hline
\end{tabular}



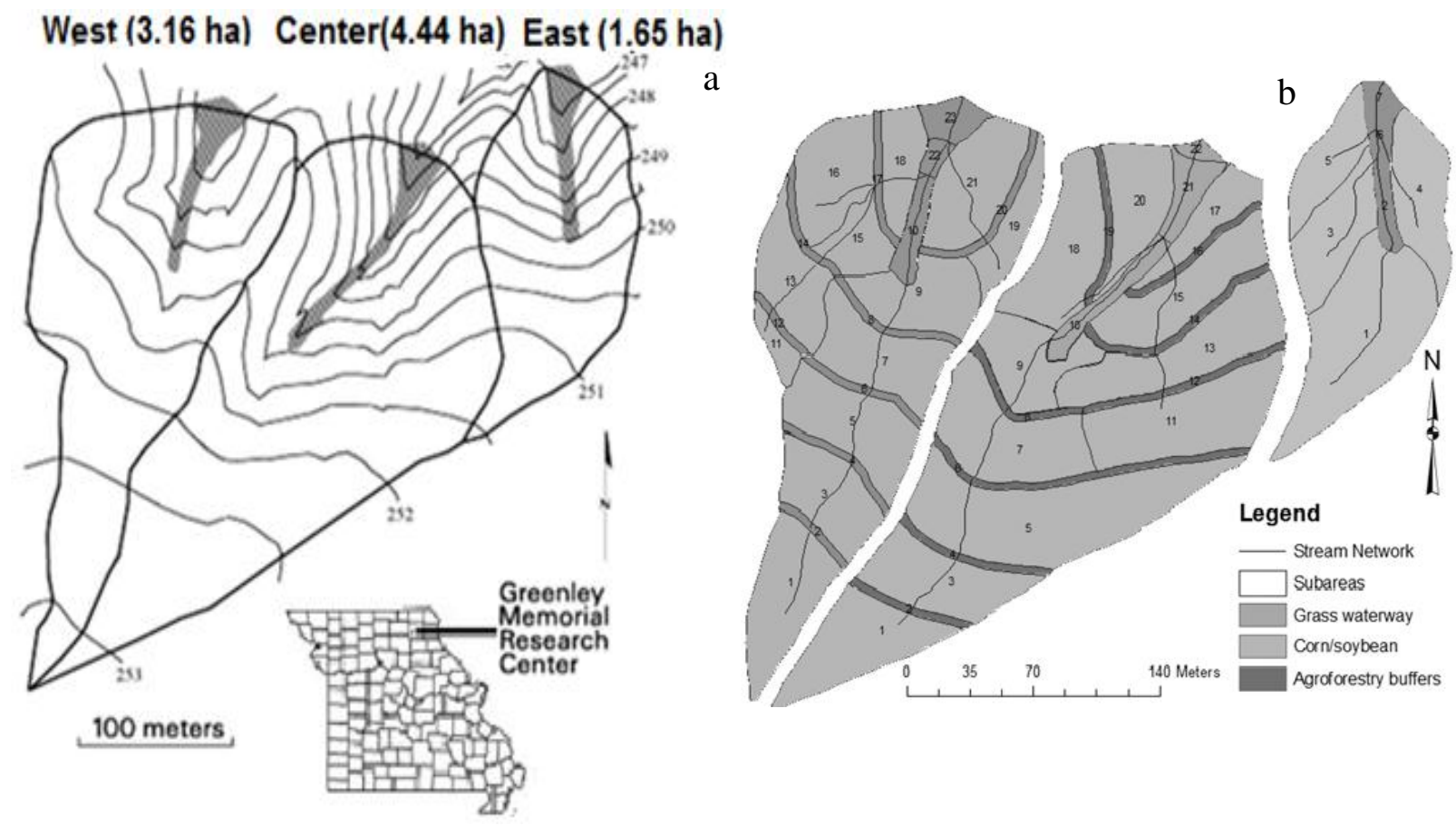

Fig. 4.1. Topographic map (0.5-m interval) of West, Center and East watersheds (a; After Udawatta et al., 2004). Grey lines represent contour lines (thin) and grass waterways (wide). The inset map shows the approximate location of the study site in Knox County, Missouri. ArcAPEX model delineated subareas, and stream network of the three watersheds (b). 

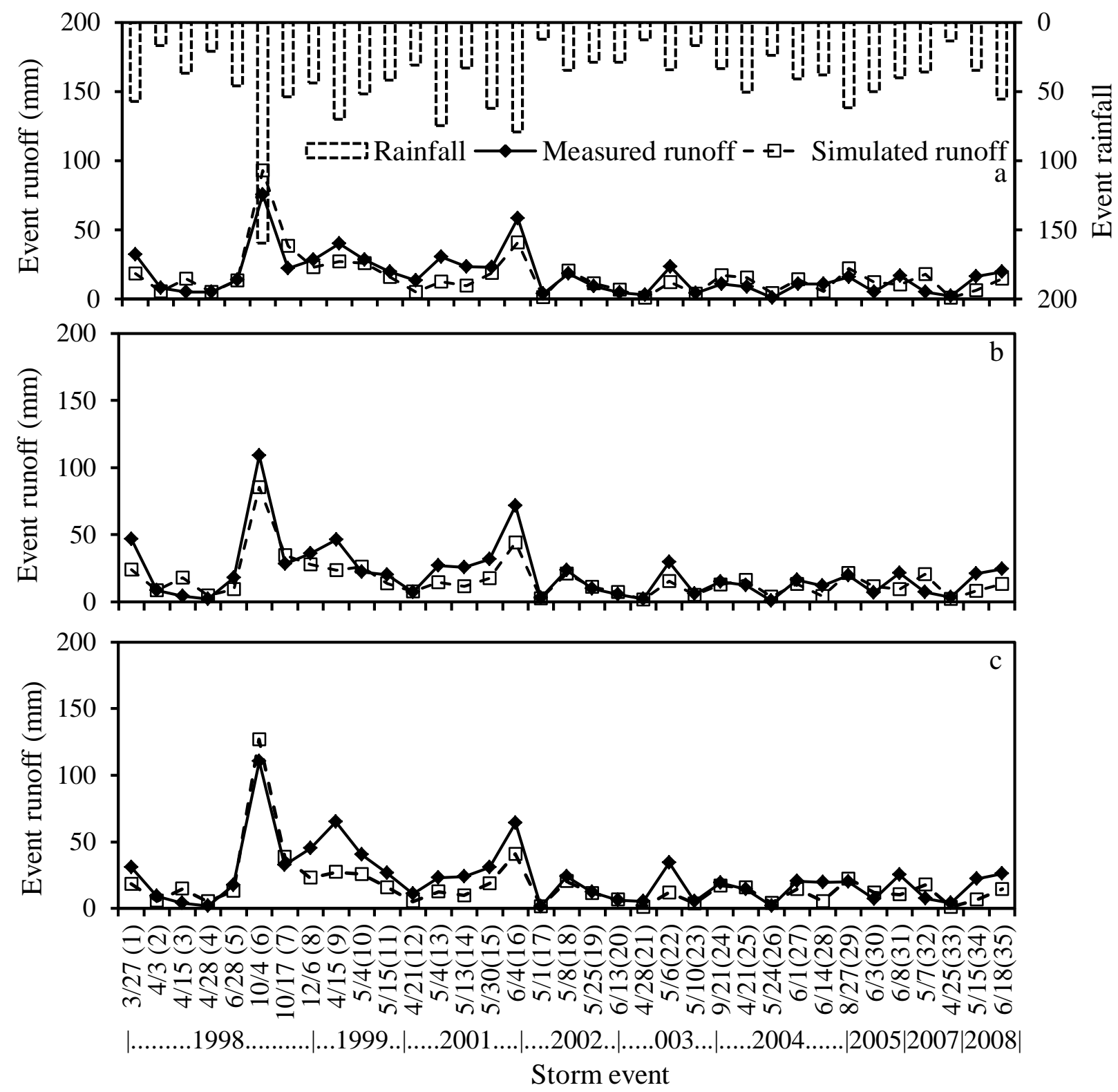

Fig. 4.2. Measured and simulated event-based runoff for Agroforestry buffer (a), Grass buffer (b), and Control (c) watersheds during the study period at the paired watershed study, Greenley Research Center, Missouri, USA. The events 1 to 14 (1998-2001) represent results for calibration while events 15 to 35 (2002-2008) represent results for validation of all three watersheds. Please note that the $\mathrm{x}$-axis values are independent events and are not continuous. 


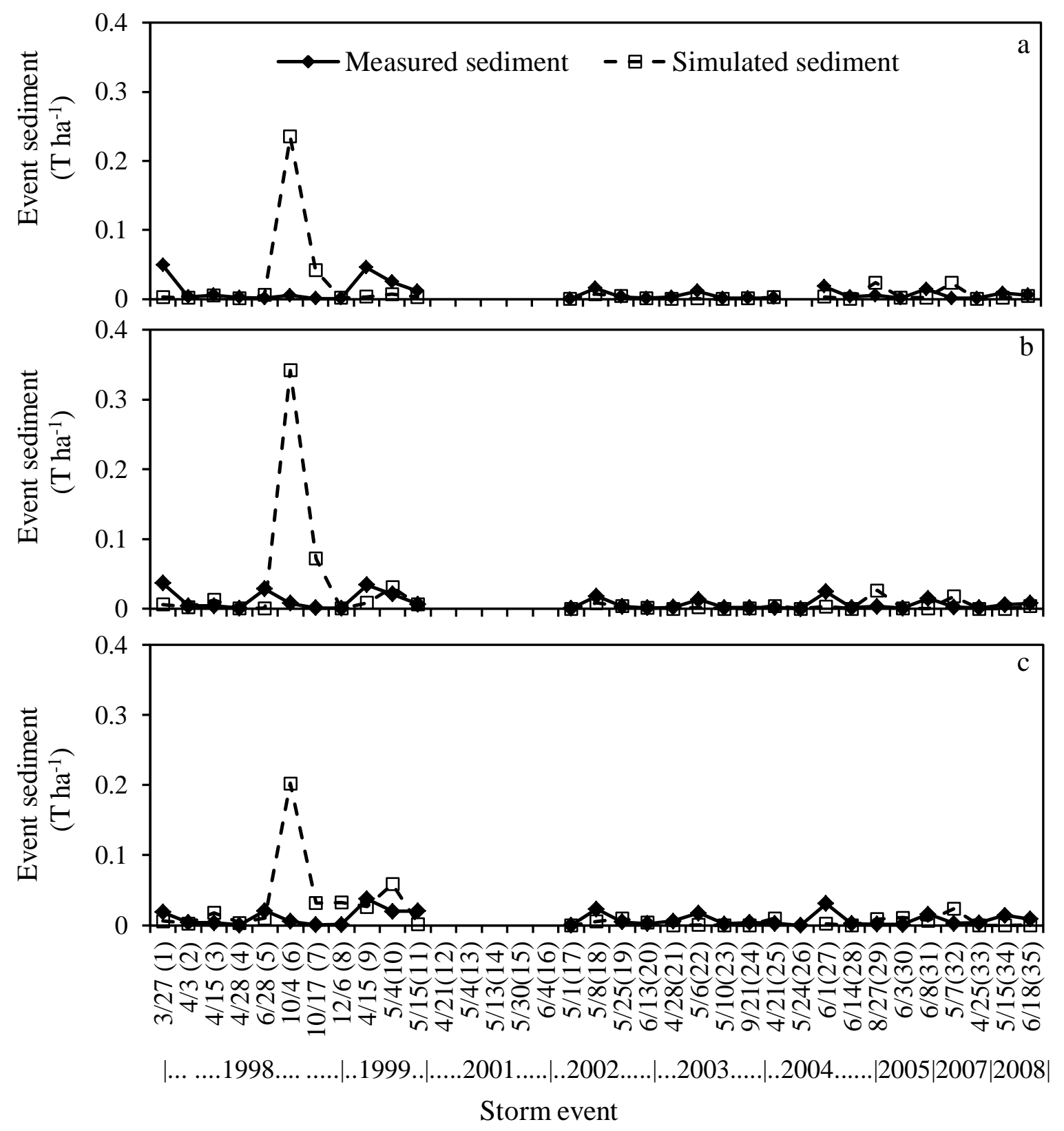

Fig. 4.3. Measured and simulated event-based sediment for Agroforestry buffer (a), Grass buffer (b), and Control (c) watersheds during the study period at the paired watershed study, Greenley Research Center, Missouri, USA. The events 1 to 14 (1998-2001) represent results for calibration while events 15 to 35 (2002-2008) represent results for validation of all three watersheds. . Please note that the $\mathrm{x}$-axis values are independent events and are not continuous. 

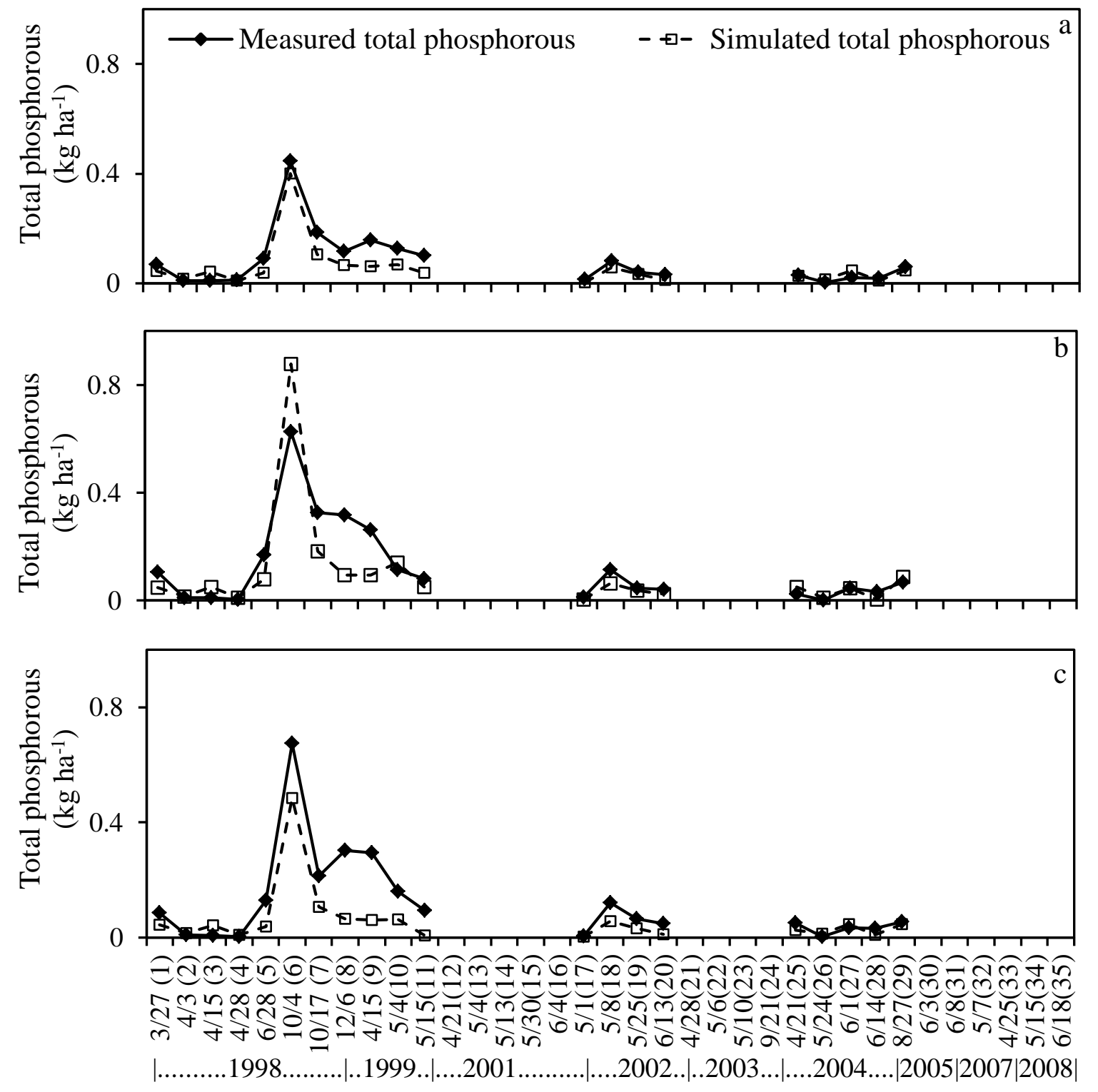

Storm event

Fig. 4.4. Measured and simulated event-based total phosphorous for Agroforestry buffer (a), Grass buffer (b), and Control (c) watersheds during the study period at the paired watershed study, Greenley Research Center, Missouri, USA. The events 1 to 14 (1998-2001) represent results for calibration while events 15 to 35 (20022008) represent results for validation of all three watersheds. Please note that the $\mathrm{x}$-axis values are independent events and are not continuous. 

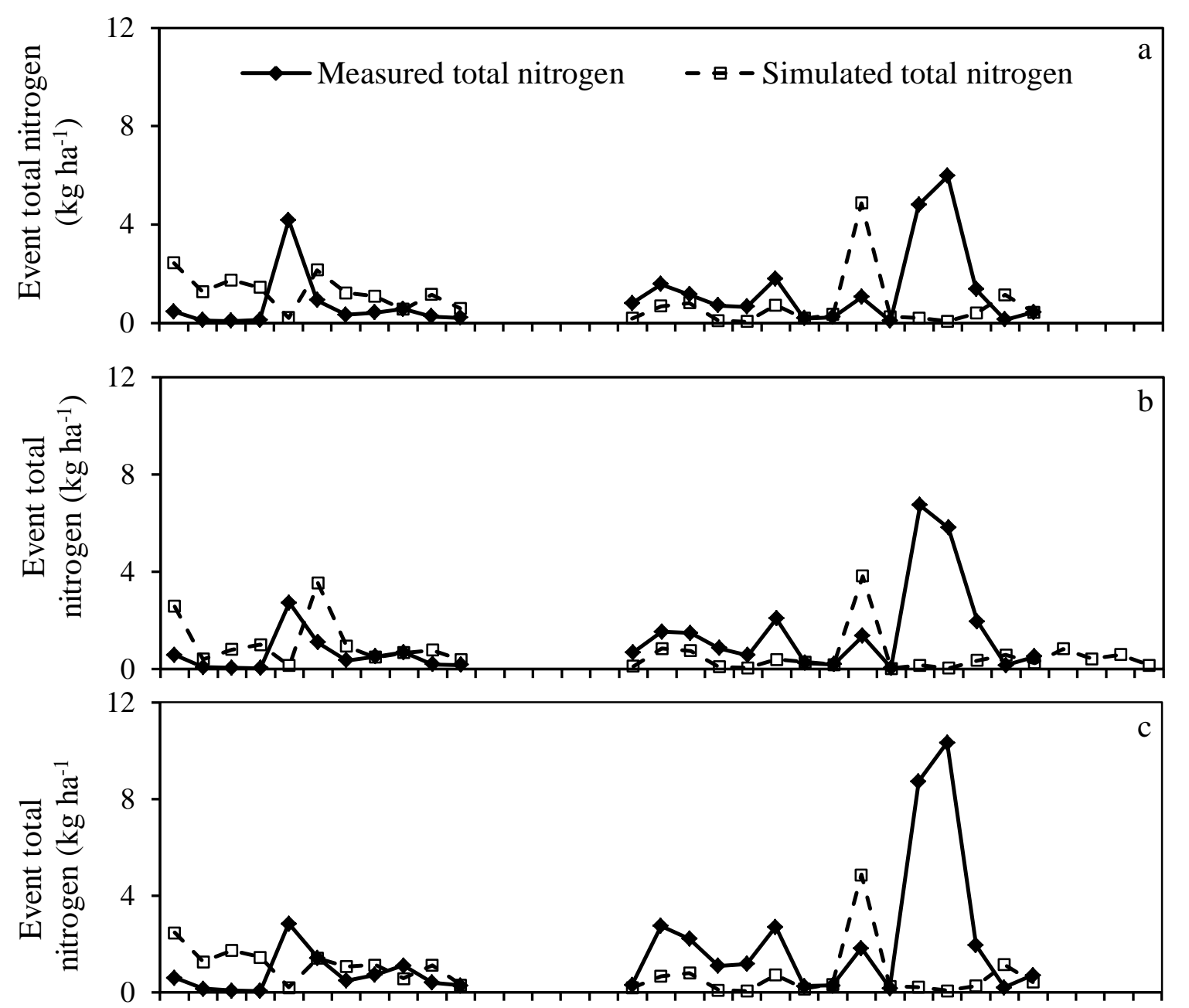

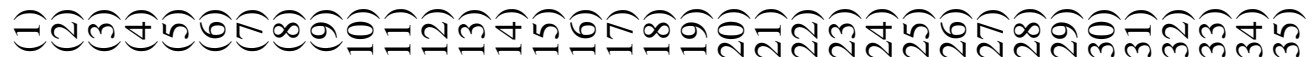

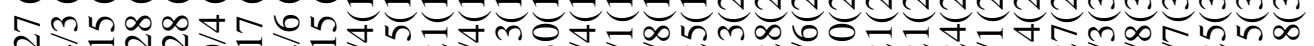

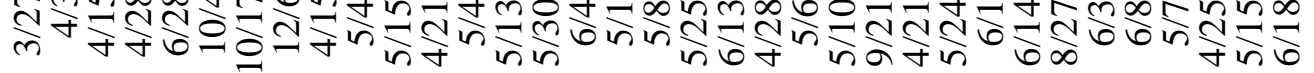
|.........1998...........1999......2001..............2002..|..2003...|...2004....|2005|2007|2008|

Storm event

Fig. 4.5. Measured and simulated event-based total nitrogen for Agroforestry buffer (a),

Grass buffer (b), and Control (c) watersheds during the study period at the paired watershed study, Greenley Research Center, Missouri, USA. The events 1 to 14 (1998-2001) represent results for calibration while events 15 to 35 (2002-2008) represent results for validation of all three watersheds. . Please note that the $\mathrm{x}$ axis values are independent events and are not continuous. 

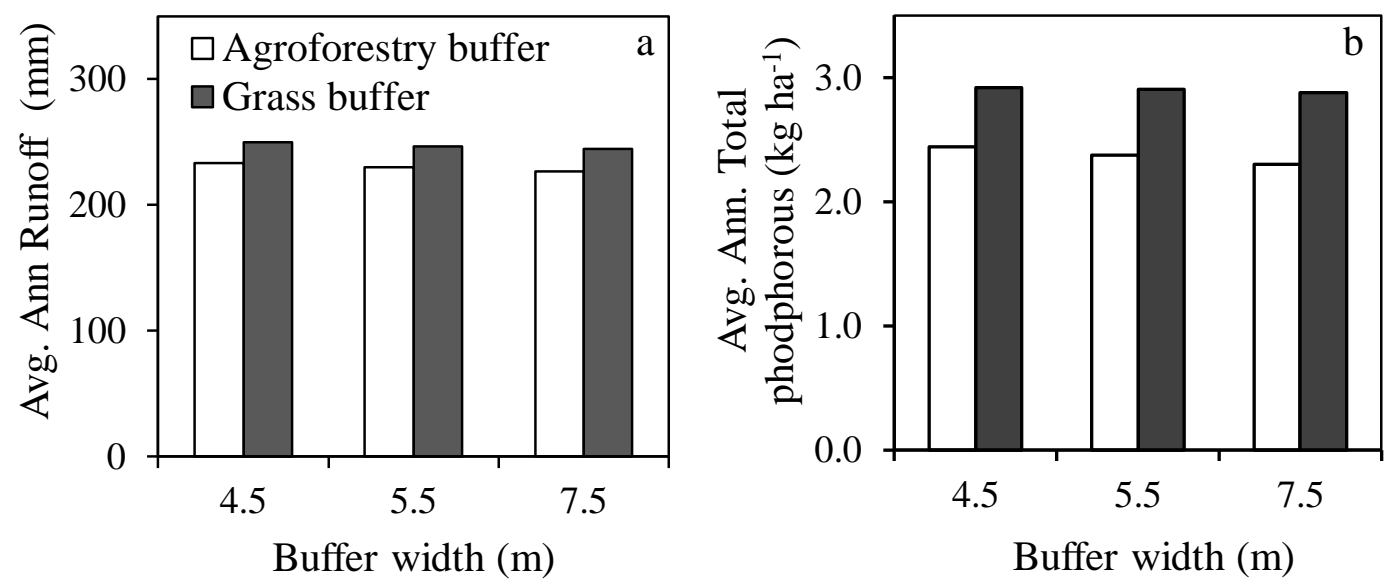

Fig. 4.6. APEX model predictions for average annual runoff (a), and average annual total phosphorous (b) losses for agroforestry and grass buffer watersheds, at the paired watershed study, Greenley Research Center, Missouri, USA, with 4.5, 5.5, and 7.5 m buffer widths. 

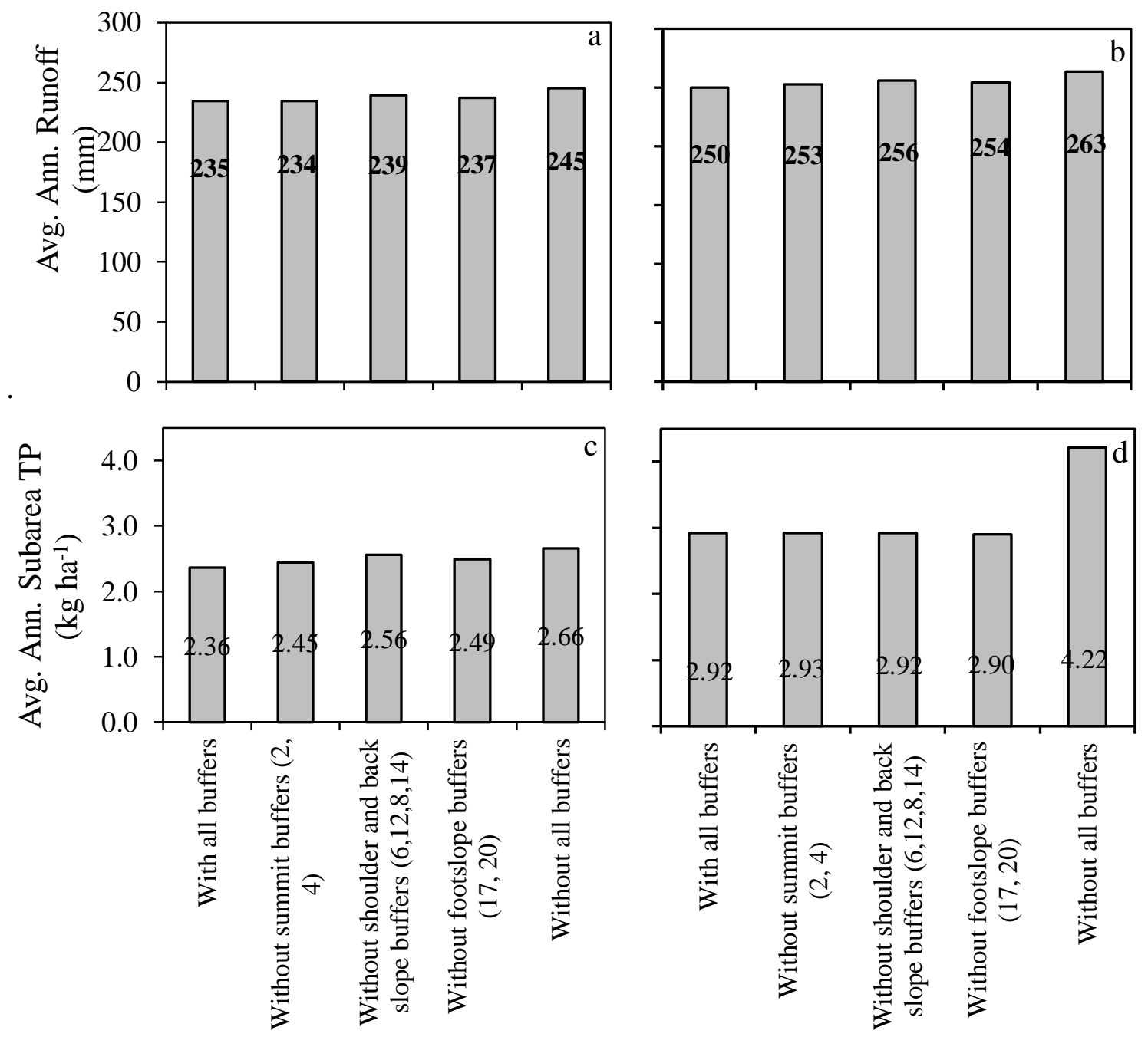

Fig. 4.7. APEX model predictions for average annual runoff and average annual total phosphorous for agroforestry buffer ( $a$ and b) and grass buffer (c and d) watersheds, at the paired watershed study, Greenley Research Center, Missouri,USA, with varying buffers at summit, shoulder and back slope, and foot slope position of the watershed landscape. 


\title{
5. CHAPTER
}

\section{PERFORMANCE OF GENO-FUZZY MODEL ON RAINFALL- RUNOFF PREDICTIONS IN CLAYPAN WATERSHEDS}

\begin{abstract}
Fuzzy logic provides a relatively simple approach to simulate complex hydrological systems while accounting for the uncertainty of environmental variables. The objective of this study was to develop a fuzzy inference system (FIS) with genetic algorithm (GA) optimization for membership functions (MFs) for event-based rainfall-runoff prediction of three small adjacent row-crop watersheds (1.65 to 4.44 ha) with intermittent discharge in the claypan soils of North East Missouri, prior to and after the establishment of upland contour grass and agroforestry (tree+grass) buffers. A Mamdani type FIS with five MFs and five fuzzy rules was created using MATLAB 7.10.0. Two sets of MFs were developed and optimized using GA for pre- and post-buffer conditions using one of the three watersheds. They were then validated using either another watershed or a different time period. The FIS simulated event-based runoff with $r^{2}$ and Nash-Sutcliffe Coefficient (NSC) values greater than 0.65 for calibration and validation. The pre-buffer FIS simulated event-based runoff of two larger similar watersheds (140 ha and 259 ha) with $r^{2}$ values of 0.82 and 0.68 and NSC values of 0.77 and 0.53 , respectively. The GA optimization of MFs moderately improved $r^{2}$ and NSC values. These FIS predictions of event-based runoff were similar to those of
\end{abstract}


the Agricultural Policy Environmental eXtender model, a physically-based hydrological model that requires extensive input data. FIS offers an alternate modeling tool for runoff estimation in the absence of detailed watershed data.

Keywords: Agroforestry, fuzzy logic, genetic algorithm, hydrology, rainfallrunoff, watershed

\section{Introduction}

Rainfall-runoff relationships are fundamental to sediment and pollutant transport, water supply, flood forecast, design of irrigation and hydrologic structures, and water budgets (Tayfur and Singh, 2006; Yu and Yang, 2000). Furthermore, the rainfall-runoff relationships are very uncertain, dynamic in space and time, and non-linear in nature (Kadığlu and Şen, 2001). Numerous models have been developed to relate runoff with rainfall, including physically based models, or data-driven models such as linear regression models (Lohani et al., 2010). The physically based models rely on mathematical relationships that simulate the processes occurring in the system. These models require large amounts of site specific data and significant time for construction (Lohani et al., 2010; Sen, 2009). To represent complex and variable hydrologic processes involved in the transformation of rainfall into runoff, the physically based models rely heavily on restrictive assumptions and require convergence of data, which results in loss of precision. For example, these models often assume uniformity at the scale considered when applying non-linear equations such as the Soil Conservation Service (SCS) curve number equation (Beven, 2001). However, non-linear dynamics 
affect these processes because of spatial heterogeneity, and use of identical parameter values for different scales will not produce correct results (Binley et al., 1989). Other implications include the sensitivity of non-linear systems to initial and boundary conditions which are poorly known in hydrology (Stephenson and Freeze, 1974) ) and the loss of precision may occur in model predictions at extreme conditions (Beven, 2001). In most instances of hydrological studies, watershed hydrological data may not be present, but the hydrologist's perspective could provide a set of logical and rational linguistic information which can be used to formulate a preliminary set of rules (Sen, 2009). In classical hydrologic modeling, there is no facility to include expert understanding of hydrological processes in linguistic form. Data-driven fuzzy inference systems (FIS; Mamdani, 1974) based on fuzzy set theory (Zadeh, 1965) offer a unique way to incorporate such expert understanding in linguistic form into the internal structure of the modeling through fuzzy sets. Other advantages of the FIS include the ability to account for the uncertainty of environmental variables, a relatively simple approach applicable to complex systems, the robustness of the system due to the ability to account for imprecise and incomplete input data and results that are readily interpretable and communicable (Openshaw and Openshaw, 1997).

Most of the applications of FIS for non-linear rainfall-runoff modeling have been on large catchment areas with permanent streams where in discharge is measured with stream gauges (Yu and Yang, 2000; Hundecha et al., 2001; Mahabir et al., 2003; Sen and Altunkaynak, 2005; Jacquin and Shamseldin, 2006; Blume et al., 2007; Lohani et al., 
2010). Tayfur and Singh (2006) used FIS to simulate rainfall-runoff at the experimental plot scale with rainfall simulators. No study has been undertaken to see the applicability of FIS for event-based rainfall-runoff prediction for a field-scale watershed with intermittent discharge. This is important as most of the monitoring data available for testing best management practices (BMP) such as grass waterways or contour vegetative buffer strips are collected at field scale. A major problem of claypan soils in Mid West of the U.S. is the presence of an impervious layer with an abrupt $100 \%$ increase in clay content within 0.1 to $0.5-\mathrm{m}$ depth with clay content varying from $350-600-\mathrm{g} \mathrm{kg}^{-1}$ (Miles and Hammer, 1989). This causes poor drainage conditions and excessive pollutant loadings from agricultural watersheds during high precipitation events.

The goal of this study was to investigate the potential use of FIS to predict eventbased runoff from measured event-based rainfall data for three adjacent small long-term monitored corn-soybean (Zea mays L.- Glycine max L.) watersheds in the claypan soils of North East Missouri during pre- and post-establishment of contour upland agroforestry and grass buffers (Udawatta et al., 2002). Sub-objectives were to develop a FIS by defining fuzzy membership functions for input rainfall and output runoff variables, to develop a fuzzy rule (FR)-base, calibrate the model using genetic algorithm (GA) optimization for membership functions (MFs) and validate the model. Results of the calibration of FIS were compared with the results from a previous study (Senaviratne et al., 201x, in review) using a physically based model, Agricultural Environmental Policy eXtender (APEX), for the same watersheds during the same periods. The applicability of 
the FIS model was tested on two larger watersheds with conditions similar to those of the watersheds used for calibration.

\section{Study watersheds}

Three adjacent field-scale study watersheds with areas of 1.65 ha (East), 4.44 ha (Center) and 3.16 ha (West) were established with grass waterways in early 1991 at the University of Missouri Greenley Memorial Research Center in Knox County in the claypan region of Missouri, USA ( $40^{\circ} 01 \mathrm{~N}, 92^{\circ} 11^{\prime}$ W; Fig.5.1a; Udawatta et al., 2002). In 1997, permanent $4.5 \mathrm{~m}$ [15 ft.] wide contour grass-legume strips (CGS) consisting of redtop (Agrostis gigantean Roth), brome grass (Bromus spp.) and birdsfoot trefoil (Lotus corniculatus L.) were established at $36.5 \mathrm{~m}$ (at lower slope positions $22.8 \mathrm{~m}$ ) apart in the West and Center watersheds. Along the center of the grass strips, a tree line of pin oak (Quercuspalustris Muenchh.), swamp white oak (Q. bicolor Willd.) and buroak (Q. macrocarpa Michx.) were planted alternately at $3 \mathrm{~m}$ interval to establish the agroforestry buffers (AGF) in the Center watershed. The East watershed was maintained as the control. Major soils of the watersheds are Putnam silt loam (fine, smectitic, mesic Vertic Albaqualf) on 0-1\% slopes and Kilwinning silt loam (fine, smectitic, mesic Vertic Epiaqualf) on 2-5\% slopes. Armstrong loam (fine, smectitic, mesic Aquertic Halpudalf) soils have been found on 5-9\% slopes in minor portions of the watersheds. Each watershed's grass waterway leads to a concrete approach structure and an H-flume to

measure the flow rate using ISCO (Lincoln, NE, USA) bubbler flow measuring devices for each storm event. Daily rainfall data were obtained from the Novelty weather station 
(http://agebb.missouri.edu/) located within $500 \mathrm{~m}$ of the watersheds.

Two watersheds numbered as 300 and 301 with areas of 140 ha and 259 ha located within the Long Branch Watershed in Macon and Adair Counties (39 $50 \mathrm{~N}$ to 40 $05 \mathrm{~N}$ and 9032 W to $9220 \mathrm{~W}$; Fig. 5.1b; Udawatta et al., 2006), Missouri, USA were used to test the scalability of the FIS in simulating event-based runoff. Two watersheds are located closer to the watersheds used for calibration with claypan soils, and have intermittent stream discharges. Major soils of the watersheds include poorly drained Armstrong loam (fine, smectitic, mesic Aquertic Hapludalfs) at 2-25\% slopes and Clarinda silty clay loam (fine, smectitic, mesic Vertic Argiaquolls) at 5-18\% slopes of the watersheds. Table 5.1 lists the land-use and flow data used for the study and further description can be found in Udawatta et al. (2006).

\section{Fuzzy Logic Model Development}

The key idea of FL (Fuzzy logic; Zadeh, 1965) is the allowance of partial inclusion of any object to different subsets of the universal set instead of completely belonging to a unique single set. This can be described numerically by a membership function (MF), which takes on values between 0 and 1 inclusive. The FIS consists of three components: input/output MFs, a fuzzy rule (FR) base and an inference engine (Mamdani, 1974; Takagi and Sugeno, 1985).

\section{Input / output membership functions}

Fuzzy MFs are defined for all input and output variables and may take many 
forms; but in practical applications, simple linear functions, such as triangular or trapezoidal functions, are preferred over parabolic functions (Tayfur and Singh, 2006).

Event rainfall and runoff amounts from 1991 to 1997 (pre-buffer period) and 1998 to 2002 (post-buffer period) available for the Center watershed (later AGF) were divided into five categories ranging from low to high amounts with three intermediate categories in between (Mamdani, 1974; Şen, 2009). An equal number of initial membership functions were created for rainfall and runoff based on these categories and optimized with genetic algorithm (GA) as described later. Accordingly, five MFs for both rainfall and runoff were used for the FIS. These include: low, medium low, medium, medium high and high MFs. The high MF was represented as a trapezoidal shape and the rest of the MFs were represented as triangular shapes. To identify the optimum number of membership functions for rainfall and runoff, FIS was tested with two, three, four and five membership functions optimized each time with GA.

\section{Fuzzy rule-base}

The fuzzy rule-base is constructed by rules that include all possible fuzzy relations between inputs and outputs in linguistic terms of IF-THEN format (Eq. [5.1]).
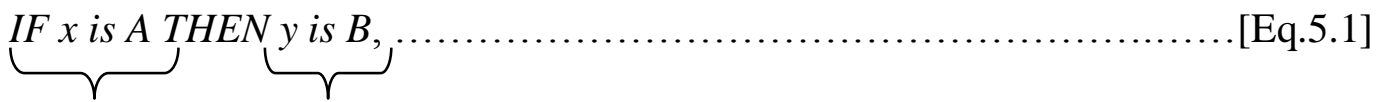

antecedent consequence 
where $\mathrm{x}$ and $\mathrm{y}$ are linguistic variables; and $\mathrm{A}$ and $\mathrm{B}$ are linguistic values determined by the fuzzy sets on the universe of discourse of $X$ and Y, respectively (Eq. 5.1). The fuzzy rules can also combine input variables using fuzzy logic operators: AND, OR or NOT.

Two types of widely used fuzzy rule systems are Mamdani FIS (Mamdani, 1974) and Takagi-Sugeno FIS (Takagi and Sugeno, 1985). The difference lies in the consequent portion of the rule; in the Mamdani rule system it is expressed verbally (Zadeh, 1965), while in the Takagi-Sugeno rule system it is expressed as a mathematical function of the input variables (Tayfur and Singh, 2006). Since the verbal conversion of single input rainfall into single output runoff was considered, the Mamdani method was selected (Tayfur and Singh, 2006) instead of the Takagi-Sugeno method for this study. Five FRs were developed linking each relative MF of rainfall to runoff (Şen, 2009) as follows:

IF Rainfall is low THEN Runoff is low,

IF Rainfall is medium low THEN Runoff is medium low,

IF Rainfall is medium THEN Runoff is medium,

IF Rainfall is medium high THEN Runoff is medium high and

IF Rainfall is high THEN Runoff is high. 


\section{Fuzzy inference engine}

The fuzzy inference engine accepts a crisp input, converts it to fuzzy input variables, processes them using the rule-base and converts the fuzzy decision to a final crisp output. The first step of the inference process is known as fuzzification or implication in which each relevant rule is activated to infer a fuzzy output variable corresponding to input variables using either min or prod operators, which either clip or scale the MFs in the rule (Jantzen, 1999). As both methods were found to work generally well (Jantzen, 1999), the min method was selected for this study.

The next step is the aggregation or composition in which all of the fuzzy subsets assigned to the output variable are combined together to form a single subset for the output variable. Two aggregation methods are used: the maximization ( $\max$ ) method which constructs the combined output fuzzy subset by taking the point-wise maximum over all of the fuzzy subsets assigned to the output variable by the inference rules and the summation (sum) method which constructs the combined output fuzzy subset by taking the point-wise sum over all fuzzy subsets (Tayfur and Singh, 2006). The max method was selected for the current study as the sum method sometimes produces degree of truth values greater than one (Jantzen, 1999).

The final step of the inference process is known as defuzzification in which the combined fuzzy output is converted to a crisp output. A number of defuzzification methods are in use, such as center of gravity (COG) or centroid, bisector of area (BOA),

mean of maxima (MOM), left-most maximum (LM) and right-most maximum (RM; 
Jantzen, 1999). According to Jantzen (1999), some methods such as MOM, LM and RM do not consider the shape of the fuzzy output set and are used for particular problems. The BOA method selects the abscissa of the vertical line that divides the area of the combined fuzzy output into two equal halves, and the COG method selects the abscissa of the center of gravity of the combined fuzzy output (Jantzen 1999). The COG method, the most commonly used method for defuzzification (Jantzen, 1999), was selected for the current study.

\section{Genetic algorithm optimization}

The performance of the FIS depends on well-constructed problem-specific membership functions (fuzzy sets) and the set of rules governing the solution. The genetic algorithm developed by Holland (1975) is a heuristic iterative search technique that attempts to find the best solution in a given decision space based on a search algorithm that mimics the process of natural evolution and survival of the fittest. A parallel search using many individuals in the population instead of a single point is unique in the GA among other heuristic iterative search techniques. The GA has proven advantageous over classical optimization methods and has become a widely used automated parameter optimization method in hydrological modeling in recent years (Cheng et al., 2002; Pelletier et al., 2006). The GA has been used to optimize fuzzy membership functions in intrusion detection of computer systems (Wang and Bridges, 2000) but has not been used for optimization of MFs in rainfall-runoff FIS.

The FRs linking rainfall-runoff MFs in the current FIS were straight forward and 
further optimization would not result in any change. However, as the x-coordinates of fuzzy MFs for both event-based rainfall and runoff were made based on the observations on previous rainfall-runoff relationships of the watersheds, they were selected for further optimization using GA (Chen, 1998). The search for the best MFs (x-coordinates) of both rainfall and runoff that produce the minimum sum of squares error between the measured and FIS output for runoff was the target of GA optimization in this study. Fuzzy tools of MATLAB 7.10.0 were used for the development of GA optimized FIS. The flowchart (Fig. 5.2) depicts the program flow of the developed geno-fuzzy model. The developed geno-fuzzy model enabled the user to input the initial MF x-coordinates for the rainfall and runoff chromosomes. Initial population of 50 chromosomes for both rainfall and runoff were obtained by changing the $\mathrm{x}$-coordinate value (except the minimum and maximum) by a random percentage within $\pm 10 \%$ variation (Wang and Bridges, 2000). The measures were taken to automatically adjust the related coordinates as some MFs had overlapping coordinates.

The performance of each solution or chromosome pair of rainfall and runoff was evaluated for fitness by the FIS and the sums of squares error was determined between the measured and FIS predicted runoff which corresponds to the fitness of each chromosome. The measured event based runoff data of the Center watershed for the prebuffer period (1993 to 1997; 42 events) were used for the fitness evaluation to select the best chromosomes representing the set of MFs for rainfall and runoff (FIS model calibration). 
The chromosomes of each generation were sorted and ranked according to their fitness values. A combination of the Elitism and Roulette Wheel selection, (Andrade et al., 2008) was used to select parents based on fitness values to ensure that the best individuals were kept while maintaining a wide representation in this study. Therefore, the first pair of parents was selected based on Elitism, and the rest of the parent pairs were selected using the Roulette Wheel selection for both rainfall and runoff chromosomes.

Random one-point crossover was selected for this study as MF x-coordinate points represented in the chromosomes were not expected to vary widely (Andrade et al., 2008). The crossover probability used was 0.8 . The new offspring was subjected to a mutation process according to a mutation probability of 0.1 to introduce new traits that may not have been in the initial population (Mahinthakumar and Sayeed, 2005). The mutation was carried out in this study by using the same procedure used to create the initial population, i.e., by changing a random gene by a random percentage within $\pm 10 \%$. As stated previously, each change was reflected in all related coordinate points of other MFs.

One hundred iterations of reproduction of new generations were carried out, and the chromosome pair of rainfall and runoff that produced the minimum sum of squares error between measured and the FIS runoff was selected as the best $\mathrm{x}$-coordinates for the GA optimized MFs. The process was first conducted for the pre-buffer FIS and repeated for each post-buffer (AGF and CGS) watershed. The details of watershed data and the number of events used for calibration and validation are listed in Table 5.1. The FIS for 
the pre-buffer period was optimized with the GA for MFs based on event-based rainfallrunoff data from the Center watershed and was validated with event-based runoff data from the post-buffer period of the Control (East) watershed since land-use was similar to that of the Center watershed during the pre-buffer period. The GA optimization process was also tested for its sensitivity to the number of events and the period used for optimization in order to identify the minimum requirement of historical data.

The FIS for the AGF watershed for the post-buffer period was optimized on event-based rainfall-runoff data from 1998 to 2001 and validated with data from 2002 to 2008 of the same watershed. The same MFs developed for the FIS of the AGF watersheds were used for the CGS watershed because no significant differences were found in measured event-based runoff between the two watersheds (Udawatta et al., 2011). The FIS for the CGS watershed was optimized on event-based rainfall-runoff data from 1998 to 2001 and validated with data from 2002 to 2008 of the same watershed. The GA optimized FIS model for pre-buffer watersheds was used to simulate event-based runoff from 1997 to 1999 (36 events for both watersheds) for the two 30 and 50 times larger Long Branch watersheds (Table 5.1). The GA optimized FIS for the AGF and CGS watersheds were then used to predict the reduction in runoff if buffers were established in the Long Branch watersheds.

\section{APEX model}

The results of FIS output for the pre-buffer period were compared with the previous study results of event-based runoff output from the physically based APEX 
model (Williams et al., 1998) for the same watersheds for the same period (Senaviratne et al., 2013). Simulations of watersheds were carried out using topography, land use and soil data available for the watersheds using the APEX model. Site specific soil data included depth to claypan, texture, cation exchange capacity, organic carbon content, $\mathrm{pH}$, saturated hydraulic conductivity, field capacity, permanent wilting point and bulk density (Seobi et al., 2005; Udawatta et al., 2002). The crop management information available for the watersheds was used for this study (Dr. K. Nelson, Greenley Memorial Research Center, personal communication). Daily measured weather including precipitation, maximum and minimum temperatures and solar radiation were obtained from the Novelty weather station (http://agebb.missouri.edu) were used for the model. The modified Soil Conservation Service (SCS) curve number method (USDA-NRCS, 1986) was selected for estimating runoff with the model as this method has been found to be reliable, has been used for many years in the U.S., is computationally efficient, uses readily available daily rainfall data and takes into account soil type, land-use and management practices in the runoff estimation (Williams et al., 2006). The modified rational method for estimating the peak runoff rate was selected for the model (USDANRCS, 1986). The Hargreaves and Samani (Hargreaves and Samani, 1985) method was selected for estimating potential evaporation by the model as it was found to be as efficient as the Penman method using only extra terrestrial radiation and air temperature (Oudin et al., 2005). The Penman method also requires wind speed and relative humidity, data which were not available for the current study. 
A parameter sensitivity analysis for the APEX model was carried out as suggested by Lenhart et al. (2002) and according to the user manual of APEX (Williams et al., 2008). Table 5.2 lists the parameters found most sensitive for runoff (Senaviratne et al., 2013). These parameters were used for calibrating the APEX model for event-based runoff for pre-buffer and post-buffer periods of the watersheds. The performances of both the FIS and the APEX models were evaluated using coefficients of determination $\left(r^{2}\right)$, Nash-Sutcliffe coefficients (NSC; Nash and Sutcliffe, 1970) and the percent bias (Pbias) between measured and predicted event runoff.

\section{Results and discussion \\ Genetic algorithm optimization}

The GA optimization of MFs (Fig. 5.3; Table 5.3) resulted in slight to moderate improvement in model goodness of fit coefficients of $r^{2}$ and NSC of the FIS for both preand post-buffer watersheds (Table 5.4). These findings demonstrate that the FIS was able to predict runoff with satisfactory model performance coefficients even without the GA optimization. The optimization of $\mathrm{x}$-coordinates MFs using GA for rainfall-runoff models has not been reported earlier. However, GA has been used for parameter optimization of the rule-base of Takagi-Sugeno rainfall-runoff fuzzy optimal model (Cheng et al., 2002). Pelletier et al. (2006).used GA for parameter optimization of the QUAL2K water quality model for dissolved oxygen in streams and rivers. Both studies have reported that the use of GA has improved model accuracy and efficiency. 


\section{Sensitivity of membership functions}

Increasing the number MFs from 2 to 5 resulted in significant improvement in the FIS model performances during calibration and validation (Table 5.5). The NSC values increased from -0.22 to 0.83 when the number of MFs was increased from 2 to 5 , and the corresponding Pbias values were reduced from -93.8 to -3.68 . The increase in $r^{2}$ values was not as significant as it was for NSC and Pbias values. An increase from 4 MFs to 5 MFs resulted in a slight improvement in model performances; hence, 5 MFs were considered sufficient to offer the optimum performance for the FIS for the current study. Sen and Altunkaynak (2006) also used 5 MFs for a fuzzy rainfall-runoff prediction model while Mahabir et al. (2003) stated that increasing MFs from 3 to a higher value would have improved their results for a fuzzy seasonal runoff forecast model.

\section{Varying the number of years and events used for calibration}

It was apparent that rather than the number of years, the availability of number of storm events representing both large and small events were sufficient for the FIS system to be calibrated using GA optimization and to be validated (Table 5.6). The minimum number of events used were 17 (occurred within the year 1993), and they were sufficient to calibrate and validate the FIS model with a resulting performance similar to the highest number of events used (42). A minimum number of 3 to 5 rainfall events for each category of rainfall: low $(\leq 20 \mathrm{~mm})$, medium $(21-49 \mathrm{~mm})$ and high $(\geq 50 \mathrm{~mm})$ were sufficient for good calibration and validation in this study. The fuzzy inference system predictions were based primarily on the initial definition of MFs which were made based 
on the observation of the available historical data. This study indicates that proper definition of the initial MFs based on historical data, along with the higher number of MFs (five), were the primary factors for better model performance. Hence, the presence of sufficient historical data at varying storm intensities, including extreme cases are vital to capture rainfall-runoff relationships for defining proper membership functions especially for long-term simulations (Tayfur and Singh, 2006).

\section{Fuzzy inference system simulations compared to APEX model predictions for pre-and post-buffer watersheds at Greenley Memorial Research Center}

The GA optimized FIS predictions on event-based runoff from pre-buffer watersheds were close to the APEX model predictions for calibration (Fig.5.4a; Center watershed during 1993 to 1997 period) and for validation (Fig. 5.4b; East watershed during 1998 to 2008 period). The $r^{2}$ and NSC values for the FIS with the GA optimization were similar to those of the APEX model, i.e., ranging between 0.69 and 0.94 for calibration and validation (Table 5.4). The percent bias values were less than $\pm 20 \%$ for event-based runoff.

The predictions by the GA optimized FIS for event-based runoff of the postbuffer AGF (Fig. 5.5a) and CGS (Fig. 5.5b) watersheds also produced similar responses as the APEX model for calibration (1998 to 2001; events 1 to 14) and validation (2002 to 2008; events 15 to 35 ). The $r^{2}$ and NSC values (ranging from 0.70 to 0.80 ) were similar to those of the APEX model (ranging from 0.61 to 0.74 ) for both calibration and validation (Table 5.3). In addition to the evaluation of model performance by 
comparison of measured and simulated flow, the simulation of buffer effectiveness was also investigated. The average measured reductions in the event-based runoff due to the establishment of buffers were $15 \%$ and $23 \%$ for AGF and CGS watersheds, respectively. The FIS simulated these reductions as $15 \%$ and $16 \%$, respectively. The FIS was able to simulate the exact percent reductions in runoff by the AGF buffers but under-predicted the effect of CGS buffers.

The calibration and validation data were switched (data used for validation previously were used for calibration and vice versa; Table 5.1) in order to evaluate the efficiency of the GA optimized FIS model for both pre- and post-buffer watersheds. The model was able to be calibrated and validated with performance coefficients within \pm 0.11 difference for $r^{2}$ and NSC values and within $\pm 3.05 \%$ difference for Pbias values as compared to the former values. The resultant MFs after the GA optimization did not show much change except for the pre-buffer FIS model (Fig. 5.6). The pre-buffer MFs for runoff optimized for the East (Control) watershed showed the largest deviations from the MFs optimized for the pre-buffer Center watershed. This result may be attributed to the differences in watershed characteristics. The least differences in MFs for the FIS models for the AGF and CGS watersheds after data switching may be due to the fact that both data belong to the same watersheds but different periods.

Tayfur and Singh (2006) also reported that the FL based model produced satisfactory results similar to the physically based kinematic wave approximation model (KWA) and an Artificial Neural Network (ANN) model for runoff predictions based on 
simulated rainfall in a plot scale study. Şen and Altunkaynak (2006) reported that FIS provided better estimates than the classical regression methods which was used to estimate runoff based on rainfall for two drainage basin studies conducted in Istanbul, Turkey. Mahabir et al. (2003) stated that the fuzzy model forecast of water supply from potential snowmelt runoff was considerably more reliable than the regression model for the two basins, especially in forecasting low and average runoff events. The advantage of the FIS was that by changing the initial MF coordinates, it could be adapted to model another watershed based on historical rainfall-runoff data. This requires minimal time and effort compared to the physically based models which require large amounts of data and time for construction. However, the FIS models do not provide an alternative to the physically based models like APEX, which physically simulates the complex processes of a watershed and produces a multitude of outputs in addition to runoff. The physically based models like APEX also facilitate detailed analysis of the watershed hydrology affected by various management practices where as the FIS models are not facilitated with such capabilities. Jacquin and Shamseldin (2006) cautioned that a series of models should be tested in order to choose the best model for a given situation.

\section{Fuzzy inference system simulation of larger Long Branch watersheds}

The GA optimized FIS developed for the pre-buffer watersheds predicted event-

based runoff for larger watersheds at the Long Branch fairly well (Table 5.7). The $r^{2}$ and NSC values were greater than 0.7 for the watershed-300 with $86 \%$ row-crop and greater than 0.5 for the watershed-301 with $77 \%$ row-crop (Table 5.1). The reason for the lower 
model performance for the watershed-301 may be that the watersheds used for calibrating the FIS were $100 \%$ row-crop excluding the grass waterway. However, according to Moriasi et al. (2007), model performance coefficients greater than 0.5 are acceptable for daily events, and thus the FIS was able to reasonably scale up the predictions for these 30 and 50 times larger watersheds with similar soils.

Application of the post-buffer FIS model on the Long Branch watersheds showed $11 \%$ and $8 \%$ reductions in event-based runoff if established with the agroforestry and grass buffers in the watershed-300, respectively and $15 \%$ and $7 \%$ reductions in the watershed-301, respectively. These reductions are in the same order, but slightly less than the reductions of measured or predicted for post-buffer watersheds at Greenly Memorial Research Center. The inclusion of pasture in the land-use distributions of watershed-301 is likely to have an effect on the predictions of the FIS optimized for rowcrop only watersheds.

\section{Conclusions}

The FISs with the GA optimization predicted event-based runoff with the model performance coefficients of $r^{2}$ and NSC values between 0.68 and 0.84 for both the preand post-buffer corn-soybean watersheds with intermittent stream discharge and claypan soils during calibration and validation. Fewer than four MFs produced poor model performances. The GA optimization of the x-coordinates of MFs moderately improved model performance of the FIS for both pre- and post-buffer periods. The creation of the initial membership functions for rainfall and runoff was the primary factor to the 
successful model performance in this study, and the presence of historical data representing various intensity storm events are important for such definition. The FIS predictions for post-buffer watersheds showed 15 to $16 \%$ reductions in the event-based runoff due to the presence of buffers compared to the pre-buffer period. This was comparable with 15 to $23 \%$ reductions in measured runoff due to the presence of AGF and CGS buffers. The FIS predictions for event-based runoff for the three watersheds were very close to the prediction made by the physically-based APEX model for both pre- and post-buffer watersheds. Once calibrated for the small watersheds, the FIS was able to predict event-based runoff for 30 and 50 times larger, watersheds with $r^{2}$ and NSC values between 0.53 and 0.82 . The FIS calibrated for the AGF and CGS buffer watersheds predicted 8 to $15 \%$ reductions in runoff for larger watersheds if established with agroforestry or grass buffers, respectively. The presence of long-term data for small and intermittent stream discharge watersheds and with different management practices of agroforestry and grass buffers make this study uniquely quantifying the application of FIS to such systems. The FIS could be used as an efficient tool for estimating eventbased runoff in the absence of detailed watershed data.

\section{Acknowledgements}

This work was funded through the University of Missouri Center for Agroforestry under cooperative agreements 58-6227-1-004 with the USDA-ARS. Any opinions, findings, conclusions or recommendations expressed in this publication are those of the authors and do not necessarily reflect the view of the U.S. Department of Agriculture. 
We would like to express our sincere appreciation to Andrew Buck and Tushar Kanta

Das Nakini at Electrical and Computer Engineering Department, University of Missouri, for their assistance given to this project.

\section{List of References}

Andrade, A.V., L. de. Errico, A.L.L. Aquino, L.P. de. Assis, and C.H.N.R. Barbosa. 2008. Analysis of selection and crossover methods used by genetic algorithmbased heuristic to solve the LSP allocation problem in MPLS network under capacity constraints. In 01-05 June, Rio de Janerio, Brazil.

Beven, K.J. 2001. Dalton Medal Lecture: How far can we go in distributed hydrological modelling? Hydrol. Earth Syst. Sci. 5(1): 1-12.

Binley, A.M., Beven, K.J.,, and Elgy, J.,. 1989. A physically-based model of heterogeneous hill slopes. II. Effective hydraulic conductivities. Water Resour. Res. 25: 1227-1233.

Blume, T., E. Zehe, and A. Bronstert. 2007. Rainfall-runoff response, event-based runoff coefficients and hydrograph separation. Hydrolog. Sci. J. 52: 843-862.

Chen, J. 1998. Derivation of membership functions for fuzzy variables using genetic algorithms. M.S. Thesis, Mississippi State University.

Cheng, C.T., C.P. Ou, and K.W. Chau. 2002. Combining a fuzzy optimal model with a genetic algorithm to solve multi-objective rainfall-runoff model calibration. J. Hydrol. 268(1): 72-86.

Hargreaves, G.H., and Z.A. Samani. 1985. Reference crop evapo-transpiration from temperature. Applied Eng. Agric. 1: 96-99.

Holland, J.H. 1975. Adaptation in Natural and Artificial Systems. Mit Press. p. 183.

Hundecha, Y., A. Bardossy, and H.W. Theisen. 2001. Development of a fuzzy logicbased rainfall-runoff model. Hydrolog. Sci. J. 46: 363-376.

Jacquin, A.P., and A.Y. Shamseldin. 2006. Development of rainfall-runoff models using Takagi-Sugeno fuzzy inference systems. J. Hydrol. 329(1): 154-173.

Jacquin, A.P., and A.Y. Shamseldin. 2009. Sensitivity analysis of Takagi-Sugeno-Kang rainfall-runoff fuzzy models. Hydrol. Earth. Syst. Sc. 13(1): 41. 
Jantzen, J. 1999. Design of fuzzy controllers. Dept. of Automation, Technical Rep. No. 98-E864, Technical Univ. of Denmark, Denmark.

Kadıoğlu, M., and M. Şen. 2001. Monthly precipitation-runoff polygons and mean runoff coefficients. Hydrolog. Sci. J. 46(1): 3-11.

Lenhart, T., K. Eckhardt, N. Fohrer, and H.G. Frede. 2002. Comparison of two different approaches of sensitivity analysis. Phys. Chem. Earth Parts Abc 27(9): 645-654.

Lohani, A.K., N.K. Goel, and K.K.S. Bhatia. 2010. Comparative study of neural network, fuzzy logic and linear transfer function techniques in daily rainfall-runoff modelling under different input domains. Hydrol. Process. 25(2): 175-193.

Mahabir, C., F.E. Hicks, and A.R. Fayek. 2003. Application of fuzzy logic to forecast seasonal runoff. Hydrol. Process 17(18): 3749-3762.

Mahinthakumar, G., and M. Sayeed. 2005. Hybrid genetic algorithm-local search methods for solving ground water source identification inverse problems. J. Water Resour. Plann. Manage. 131(1): 45-57.

Mamdani, E.H. 1974. Application of fuzzy algorithms for simple dynamic plant. Proc Iee (121): 1585-1588.

Moriasi, D.N., J.G. Arnold, M.W. Van Liew, R.L. Bingner, R.D. Harmel, and T.L. Veith. 2007. Model evaluation guidelines for systematic quantification of accuracy in watershed simulations. Trans. Asabe 50(3): 885-900.

Nash, J.E., and J.V. Sutcliffe. 1970. River flow forecasting through conceptual models part I - A discussion of principles. J. Hydrol. 10(3): 282-290.

Openshaw, S., and C. Openshaw. 1997. Artificial Intelligence in Geography. John Wiley \& Sons, NY.

Oudin, L., F. Hervieu, C. Michel, C. Perrin, V. Andréassian, F. Anctil, and C. Loumagne. 2005. Which potential evapotranspiration input for a lumped rain-runoff model? Part 2 - Towards a simple and efficient potential evapotranspiration model for rainfall-runoff modelling. J. Hydrol. 303: 290-306.

Pelletier, G.J., S.C. Chapra, and H. Tao. 2006. QUAL2Kw -A framework for modeling water quality in streams and rivers using a genetic algorithm for calibration. Environ. Model. Softw. 21: 419-425.

Sen, Z., and A. Altunkaynak. 2005. A comparative fuzzy logic approach to runoff coefficient and runoff estimation. Hydrol. Process. 20(9): 1993-2009. 
Sen, M. 2009. Fuzzy Logic and hydrology modeling. p. 348. In CRC Press, Taylor \& Francis group, Broken Sound Parkway, NW.

Seobi, T., S.H. Anderson, R.P. Udawatta, and C.J. Gantzer. 2005. Influence of grass and agroforestry buffer strips on soil hydraulic properties for an Albaqualf. Soil Sci. Soc. Am. J. 69(3): 893-901.

Stephenson, R., and R.A. Freeze. 1974. Mathematical simulation of subsurface flow contributions to snowmelt runoff, Reynolds Creek, Idaho. Water Resour. Res. 10(2): 284-298.

Takagi, T., and M. Sugeno. 1985. Fuzzy identification of systems and its application to modeling and control. IEEE Trans. Syst. Man. Cybern. 15: 116-132.

Tayfur, G., and V.P. Singh. 2006. ANN and fuzzy logic models for simulating eventbased rainfall-runoff. J. Hydraul. Eng. 132(12): 1321-1330.

Udawatta, R.P., J.J. Krstansky, G.S. Henderson, and H.E. Garrett. 2002. Agroforestry practices, runoff, and nutrient loss. J. Environ. Qual. 31(4): 1214-1225.

Udawatta, R.P., G.S. Henderson, J.R. Jones, and R.D. Hammer. 2006. Runoff and sediment from row-crop, row-crop with grass strips, pasture, and forest watersheds. J. Water Sci. 19: 137-149.

Udawatta, R.P., H.E. Garrett, and R. Kallenbach. 2011. Agroforestry buffers for nonpoint source pollution reductions from agricultural watersheds. J. Environ. Qual. 40(3): 800-806.

USDA/NRCS. 1986. U.S. Department of Agriculture, Soil Conservation Service. Urban hydrology for small watersheds. Tech. Release. Report no. 55. Department of Agriculture, Soil Conservation Service.

Wang, W., and S. Bridges. 2000. Genetic algorithm optimization of membership functions for mining fuzzy association rules. In Atlantic City, NJ.

Williams, J.R., J.G. Arnold, R. Srinivasan, and T.S. Ramanarayanan. 1998. APEX: A new tool for predicting the effects of climate and $\mathrm{CO} 2$ changes on erosion and water quality. Model. Soil Eros. Water 1: 441-449.

Williams, J.R., W.L. Harman, M. Magre, U. Kizil, J.A. Lindley, G. Padmanabhan, and E. Wang. 2006. APEX feedlot water quality simulation. Trans. ASAE 49(1): 61-73.

Williams, J.R., R.C. Izaurralde, and E.M. Steglich. 2008. Agricultural policy/environmental extender model: User's manual version 0604. BREC Report 
\#2008-16. Blackland Research and Extension Center. p. 222. Available at http://epicapex.brc.tamus.edu/downloads/usermanuals.aspx. (verified 28 May 2010).

Yu, P.S., and T.C. Yang. 2000. Fuzzy multi-objective function for rainfall-runoff model calibration. J. Hydrol. 238(1): 1-14.

Zadeh, L.A. 1965. Fuzzy sets. Inform. Control 8: 338-353. 
Table 5.1. Details of watershed data used for calibration and validation of the fuzzy inference system.

\begin{tabular}{|c|c|c|c|}
\hline Watershed & $\begin{array}{l}\text { Area } \\
\text { (ha) }\end{array}$ & Land-use & $\begin{array}{l}\text { Usage-period, } \\
\text { number of event }\end{array}$ \\
\hline \multicolumn{4}{|l|}{ Greenley Memorial Research } \\
\hline \multicolumn{4}{|l|}{ Center, Knox County, Missouri. } \\
\hline Center watershed & 4.44 & $\begin{array}{l}95 \% \text { Row-crop } \\
5 \% \text { grass } \\
\text { waterway }\end{array}$ & $\begin{array}{l}\text { Calibration, 1993- } \\
\text { 1997, } 42 \text { events } \\
\text { Validation, 1998- } \\
2008,35 \text { events }\end{array}$ \\
\hline East (Control) watershed & 1.65 & $\begin{array}{l}91 \% \text { Row-crop } \\
9 \% \text { grass } \\
\text { waterway }\end{array}$ & \\
\hline $\begin{array}{l}\text { Center watershed with } \\
\text { agroforestry buffers (AGF) }\end{array}$ & 4.44 & $\begin{array}{l}\text { Row-crop, } \\
\text { agroforestry } \\
\text { buffers and grass } \\
\text { waterway }\end{array}$ & $\begin{array}{l}\text { Calibration, 1998- } \\
\text { 2001, } 14 \text { events } \\
\text { Validation, 2002- } \\
\text { 2008, } 21 \text { events }\end{array}$ \\
\hline $\begin{array}{l}\text { West watershed with grass } \\
\text { Buffers (CGS) }\end{array}$ & 3.65 & $\begin{array}{l}\text { Row-crop, grass } \\
\text { buffers and grass } \\
\text { waterway }\end{array}$ & $\begin{array}{l}\text { Calibration, 1998- } \\
\text { 2001, } 14 \text { events } \\
\text { Validation, 2002- } \\
2008,21 \text { events }\end{array}$ \\
\hline \multicolumn{4}{|l|}{$\begin{array}{l}\text { Macon and Adair Counties, } \\
\text { Missouri. }\end{array}$} \\
\hline Watershed 300 & 140 & $\begin{array}{l}86 \% \text { Row-crop } \\
7 \% \text { Pasture } \\
7 \% \text { Forest }\end{array}$ & $\begin{array}{l}\text { Upscale, 1997-1999, } \\
36 \text { events }\end{array}$ \\
\hline Watershed 301 & 259 & $\begin{array}{l}77 \% \text { Row-crop } \\
22 \% \text { Pasture } \\
4 \% \text { Forest }\end{array}$ & $\begin{array}{l}\text { Upscale, 1997-1999, } \\
36 \text { events }\end{array}$ \\
\hline
\end{tabular}


Table 5.2. Most sensitive parameters used for runoff calibration for the APEX model.

\begin{tabular}{|c|c|c|c|}
\hline Parameter & Range tested $^{\dagger}$ & $\begin{array}{l}\text { Selected } \\
\text { Value }\end{array}$ & Sensitivity Rank \\
\hline $\mathrm{P}[2]$ Root growth soil strength & $1-2$ & 2 & 5 \\
\hline $\mathrm{P}[16]$ Expands $\mathrm{CN}$ retention parameter & $1-1.5$ & 1 & 4 \\
\hline$P$ [17] Soil evaporation-plant cover factor & $0.01-0.5$ & 0.2 & 2 \\
\hline P[23] Hargreaves PET equation coefficient & $0.0023-0.0032$ & 0.0025 & 2 \\
\hline P[34] Hargreaves PET equation exponent & $0.5-0.6$ & 0.5 & 1 \\
\hline P[37] Crop residue Runoff & $0-2$ & 0.4 & 5 \\
\hline $\mathrm{P}[42]$ SCS curve number index coefficient & $0.5-2.5$ & 2.5 & 2 \\
\hline $\begin{array}{l}\mathrm{P}[44] \text { Upper limit of curve number retention } \\
\text { parameter }\end{array}$ & $1-2$ & 1 & 5 \\
\hline Land Use number (Operational schedule file) & $4-5$ & 4 & 4 \\
\hline Plant Available Water (Soil file) & $0.3-0.4$ & 0.3 & 5 \\
\hline
\end{tabular}

${ }^{\dagger}$ Ranges specified in the user manual (Williams et al., 2008). 
Table 5.3. Chromosomes with and without genetic algorithm (GA) optimization, consisting x-coordinate values for Low (L), Medium low (ML), Medium (M), Medium high (MH), and High $(\mathrm{H})$ membership functions for rainfall and runoff used for the fuzzy inference system for pre-buffer, agroforestry buffer and contour grass buffer watersheds.

\begin{tabular}{|c|c|c|c|c|c|c|c|c|c|c|c|c|}
\hline \multicolumn{13}{|c|}{ Chromosome values of membership function's x coordinate } \\
\hline & \multicolumn{4}{|c|}{ Pre-buffer } & \multicolumn{3}{|c|}{ Agroforestry buffer } & \multicolumn{5}{|c|}{ Contour grass buffer } \\
\hline & \multicolumn{2}{|l|}{ Rainfall } & Runoff & \multicolumn{2}{|c|}{ Rainfall } & \multicolumn{2}{|c|}{ Runoff } & \multicolumn{2}{|c|}{ Rainfall } & \multicolumn{2}{|c|}{ Runoff } & \multirow[b]{2}{*}{$\begin{array}{l}\text { With } \\
\text { GA }\end{array}$} \\
\hline & $\begin{array}{l}\text { Without } \\
\text { GA }\end{array}$ & $\begin{array}{l}\text { With } \\
\text { GA }\end{array}$ & $\begin{array}{l}\text { Withou } \\
\text { t GA }\end{array}$ & $\begin{array}{l}\text { With } \\
\text { GA }\end{array}$ & $\begin{array}{l}\text { Witho } \\
\text { ut GA }\end{array}$ & $\begin{array}{l}\text { With } \\
\text { GA }\end{array}$ & $\begin{array}{l}\text { Witho } \\
\text { ut GA }\end{array}$ & $\begin{array}{l}\text { With } \\
\text { GA }\end{array}$ & $\begin{array}{l}\text { Witho } \\
\text { ut GA }\end{array}$ & $\begin{array}{l}\text { With } \\
\text { GA }\end{array}$ & $\begin{array}{l}\text { Witho } \\
\text { ut GA }\end{array}$ & \\
\hline \multirow[t]{3}{*}{ L-Low } & 0.0 & 0.0 & 0.0 & 0.0 & 0.0 & 0.0 & 0.0 & 0.0 & 0.0 & 0.0 & 0.0 & 0.0 \\
\hline & 0.0 & 0.0 & 0.0 & 0.0 & 0.0 & 0.0 & 0.0 & 0.0 & 0.0 & 0.0 & 0.0 & 0.0 \\
\hline & 23.0 & 23.1 & 4.0 & 3.8 & 23.0 & 23.2 & 4.0 & 4.2 & 23.0 & 22.4 & 4.0 & 4.2 \\
\hline \multirow[t]{3}{*}{ ML-Medium low } & 12.0 & 11.4 & 2.0 & 2.1 & 12.0 & 12.1 & 2.0 & 1.9 & 12.0 & 12.7 & 2.0 & 2.0 \\
\hline & 23.0 & 23.1 & 4.0 & 3.8 & 23.0 & 23.2 & 4.0 & 4.2 & 23.0 & 22.4 & 4.0 & 4.2 \\
\hline & 40.0 & 38.9 & 12.0 & 12.2 & 40.0 & 38.8 & 10.0 & 9.8 & 40.0 & 39.1 & 10.0 & 10.3 \\
\hline \multirow[t]{3}{*}{ M-Medium } & 23.0 & 23.1 & 4.0 & 3.8 & 23.0 & 23.2 & 4.0 & 4.2 & 23.0 & 22.4 & 4.0 & 4.2 \\
\hline & 40.0 & 38.9 & 12.0 & 12.2 & 40.0 & 38.8 & 10.0 & 9.8 & 40.0 & 39.1 & 10.0 & 10.3 \\
\hline & 60.0 & 63.2 & 25.0 & 24.1 & 60.0 & 62.3 & 20.0 & 19.7 & 60.0 & 61.9 & 25.0 & 25.1 \\
\hline \multirow[t]{3}{*}{ MH-Medium high } & 40.0 & 38.9 & 12.0 & 12.2 & 40.0 & 38.8 & 10.0 & 9.8 & 40.0 & 39.1 & 10.0 & 10.3 \\
\hline & 60.0 & 63.2 & 25.0 & 24.1 & 60.0 & 62.2 & 20.0 & 19.7 & 60.0 & 61.9 & 25.0 & 25.1 \\
\hline & 80.0 & 79.7 & 52.0 & 53.3 & 80.0 & 82.8 & 42.0 & 43.9 & 80.0 & 83.0 & 42.0 & 43.7 \\
\hline \multirow[t]{4}{*}{ H-High } & 60.0 & 63.2 & 25.0 & 24.1 & 60.0 & 63.2 & 20.0 & 19.7 & 60.0 & 61.9 & 25.0 & 25.1 \\
\hline & 110.0 & 114.3 & 82.0 & 79.9 & 110.0 & 112.6 & 72.0 & 71.2 & 110.0 & 109.9 & 82.0 & 81.4 \\
\hline & 160.0 & 160.0 & 110.0 & 110.0 & 160.0 & 160.0 & 110.0 & 110.0 & 160.0 & 160.0 & 110.0 & 110.0 \\
\hline & 160.0 & 160.0 & 110.0 & 110.0 & 160.0 & 160.0 & 110.0 & 110.0 & 160.0 & 160.0 & 110.0 & 110.0 \\
\hline
\end{tabular}


Table 5.4. Model performance coefficients (coefficient of determination, $r^{2}$; Nash-Sutcliffe Coefficient, NSC; and percent bias, Pbias) for fuzzy inference system (FIS) before and after genetic algorithm (GA) optimization and Agricultural Policy Environmental eXtender (APEX) model during calibration and validation for event-based runoff of watersheds prior to and after buffer treatments at the paired watershed study, Greenley Research Center, Missouri, USA.

\begin{tabular}{|c|c|c|c|c|c|c|c|c|c|c|c|}
\hline \multirow{2}{*}{$\begin{array}{l}\text { Watershed } \\
\text { Treatments }\end{array}$} & & & \multicolumn{3}{|c|}{ FIS before GA } & \multicolumn{3}{|c|}{ FIS with GA } & \multicolumn{3}{|c|}{ APEX model } \\
\hline & & & $r^{2}$ & NSC & Pbias & $r^{2}$ & NSC & Pbias & $r^{2}$ & NSC & Pbias \\
\hline \multirow[t]{2}{*}{$\begin{array}{l}\text { Without } \\
\text { buffers }\end{array}$} & Calibration & $\begin{array}{l}\text { Center } \\
1993-1997\end{array}$ & 0.82 & 0.69 & -14.5 & $\begin{array}{l}0.8 \\
3\end{array}$ & 0.76 & -10.35 & 0.94 & 0.84 & 0.93 \\
\hline & Validation & $\begin{array}{l}\text { East (Control) } \\
1998-2008\end{array}$ & 0.67 & 0.66 & 6.31 & $\begin{array}{l}0.7 \\
0\end{array}$ & 0.69 & 7.87 & 0.94 & 0.87 & 19.24 \\
\hline \multirow[t]{2}{*}{$\begin{array}{l}\text { With } \\
\text { agroforestry } \\
\text { buffers }\end{array}$} & Calibration & $\begin{array}{l}\text { Center } \\
1998-2001\end{array}$ & 0.75 & 0.63 & -0.76 & $\begin{array}{l}0.8 \\
0\end{array}$ & 0.75 & 0.56 & 0.78 & 0.62 & 6.03 \\
\hline & Validation & $\begin{array}{l}\text { Center } \\
\text { 2002-2008 }\end{array}$ & 0.76 & 0.62 & - & $\begin{array}{l}0.7 \\
7\end{array}$ & 0.71 & -12.26 & 0.67 & 0.57 & -6.80 \\
\hline \multirow{2}{*}{$\begin{array}{l}\text { With } \\
\text { contour } \\
\text { grass buffers }\end{array}$} & Calibration & $\begin{array}{l}\text { West } \\
1998-2001\end{array}$ & 0.67 & 0.66 & 9.95 & $\begin{array}{l}0.7 \\
1\end{array}$ & 0.70 & 11.65 & 0.87 & 0.79 & 2.36 \\
\hline & Validation & $\begin{array}{l}\text { West } \\
\text { 2002-2008 }\end{array}$ & 0.78 & 0.77 & -0.96 & $\begin{array}{l}0.8 \\
0\end{array}$ & 0.79 & 0.64 & 0.74 & 0.66 & 12.46 \\
\hline
\end{tabular}


Table 5.5. Fuzzy inference system performance with the increase of membership functions for both rainfall and runoff.

\begin{tabular}{cccc}
\hline $\begin{array}{c}\text { Number of Membership } \\
\text { functions for rainfall and } \\
\text { runoff }\end{array}$ & \multicolumn{3}{c}{ Calibration by Center } \\
& \multicolumn{3}{c}{ watershed } \\
& $\mathrm{r}^{2}$ & NSC & Pbias \\
\cline { 2 - 4 } 2 & 0.73 & -0.22 & -93.8 \\
3 & 0.75 & 0.43 & -50.32 \\
4 & 0.80 & 0.79 & -1.2 \\
5 & 0.84 & 0.83 & -3.68 \\
\hline
\end{tabular}


Table 5.6. Model calibration and validation of fuzzy inference system using varying number of events / years of historical data.

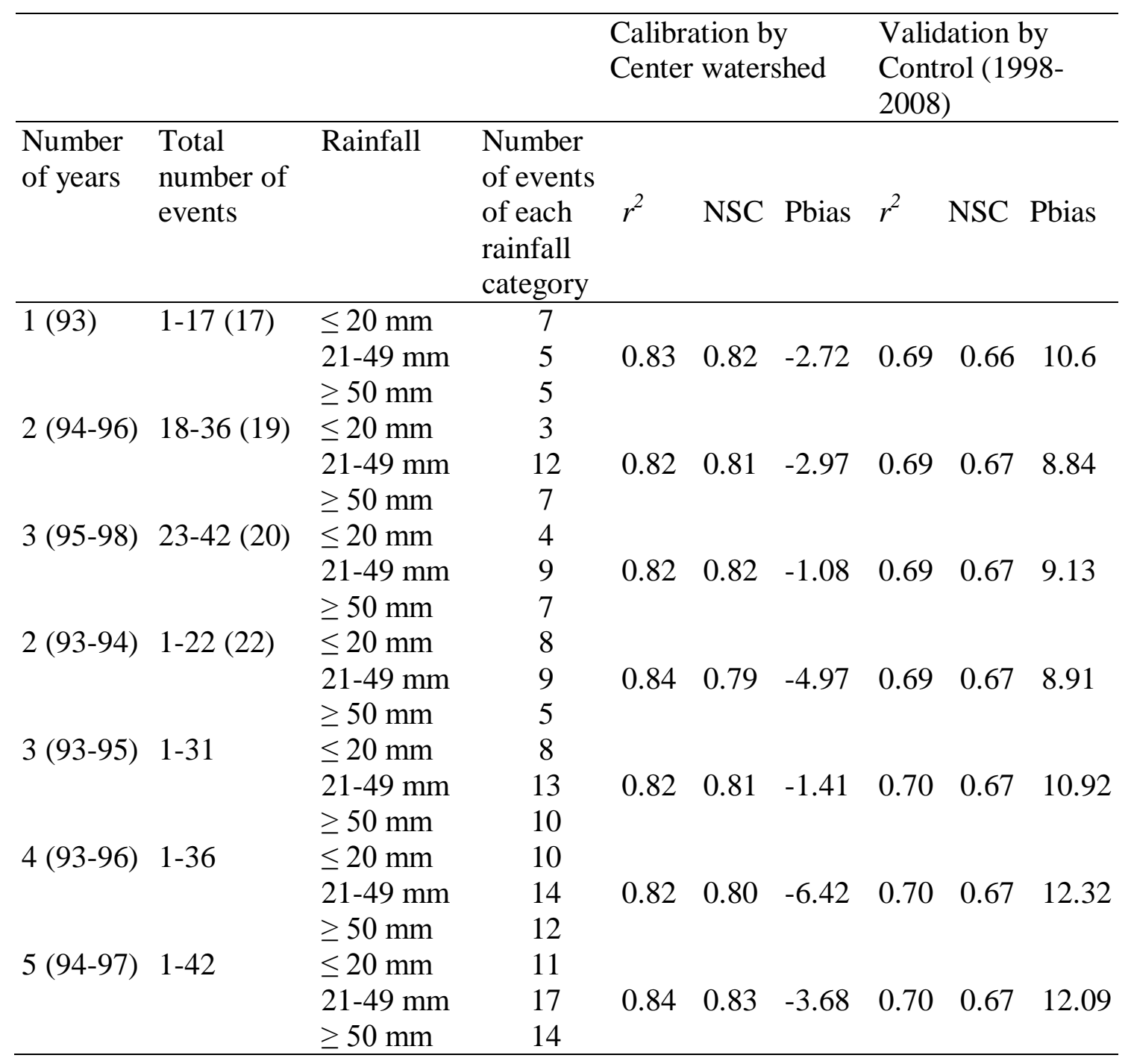


Table 5.7. Model performance indicators of Fuzzy inference system (FIS) with genetic algorithm (GA) optimization model simulations of the Long Branch watersheds in Macon and Adair Counties, Missouri, USA.

FIS with GA

Long Branch watersheds (1997-1999, 36 events)

$r^{2} \quad$ NSC $\quad$ Pbias

Watershed 300 (140 ha, 86\%

row-crop, $7 \%$ pasture, $7 \%$ forest)

$\begin{array}{lll}0.82 & 0.77 \quad 26.52\end{array}$

Watershed 301 (259 ha, 77\%

row-crop, $22 \%$ pasture, $4 \%$ forest)

$\begin{array}{lll}0.68 & 0.53 \quad 41.02\end{array}$



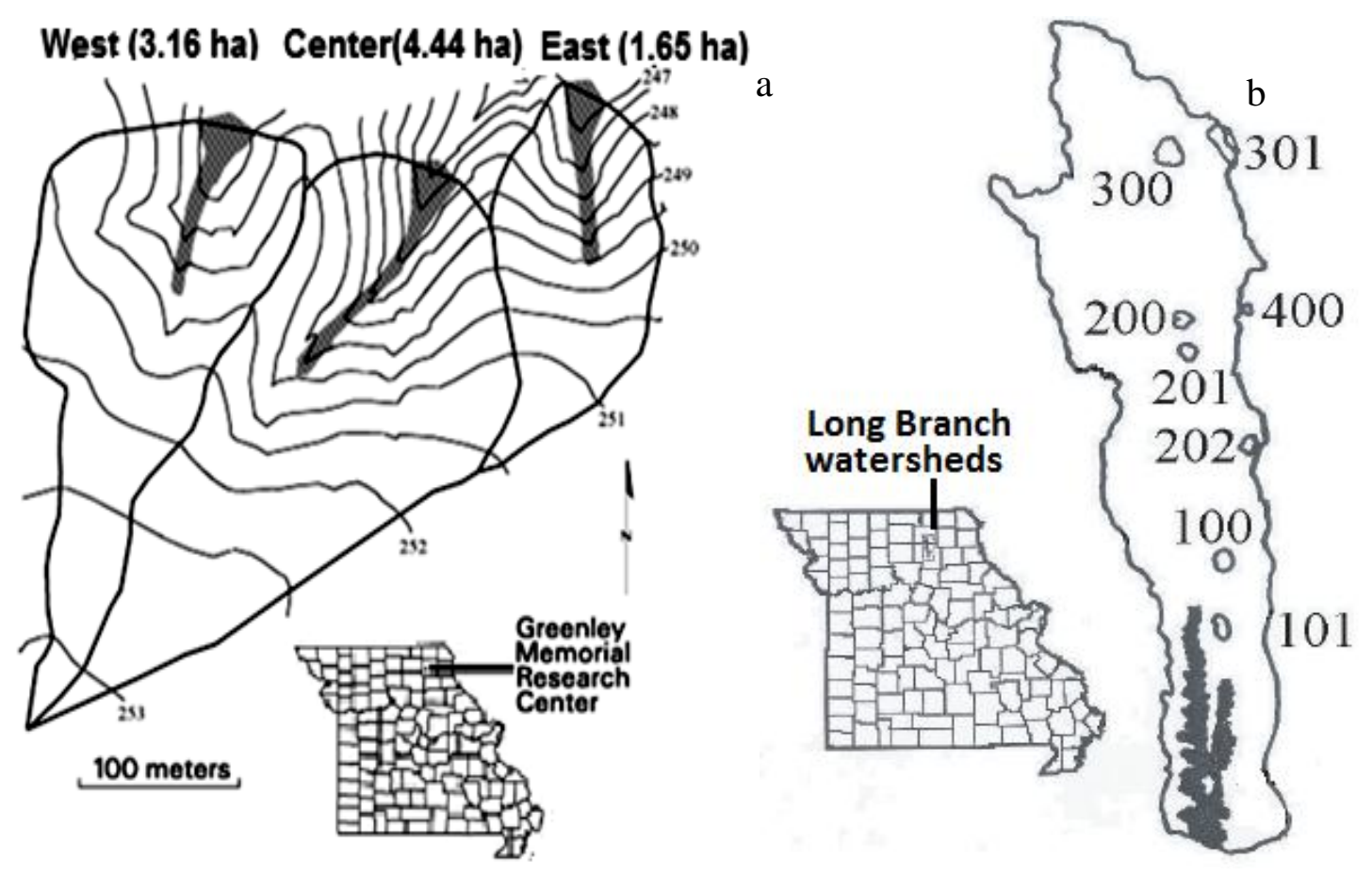

Fig. 5.1. Topographic map (0.5-m interval) of West, Center and East watersheds before establishment of buffers (a; after Udawatta et al., 2004). Grey lines represent contour lines (thin) and grass waterways (wide). The inset map shows the approximate location of the study site in Knox County, Missouri. Map of Long Branch watershed with 300 and 301 subwatersheds in Macon and Adair Counties, Missouri (b; after Udawatta et al., 2006). The inset map shows the approximate location of the Long Branch watersheds in, Missouri. 


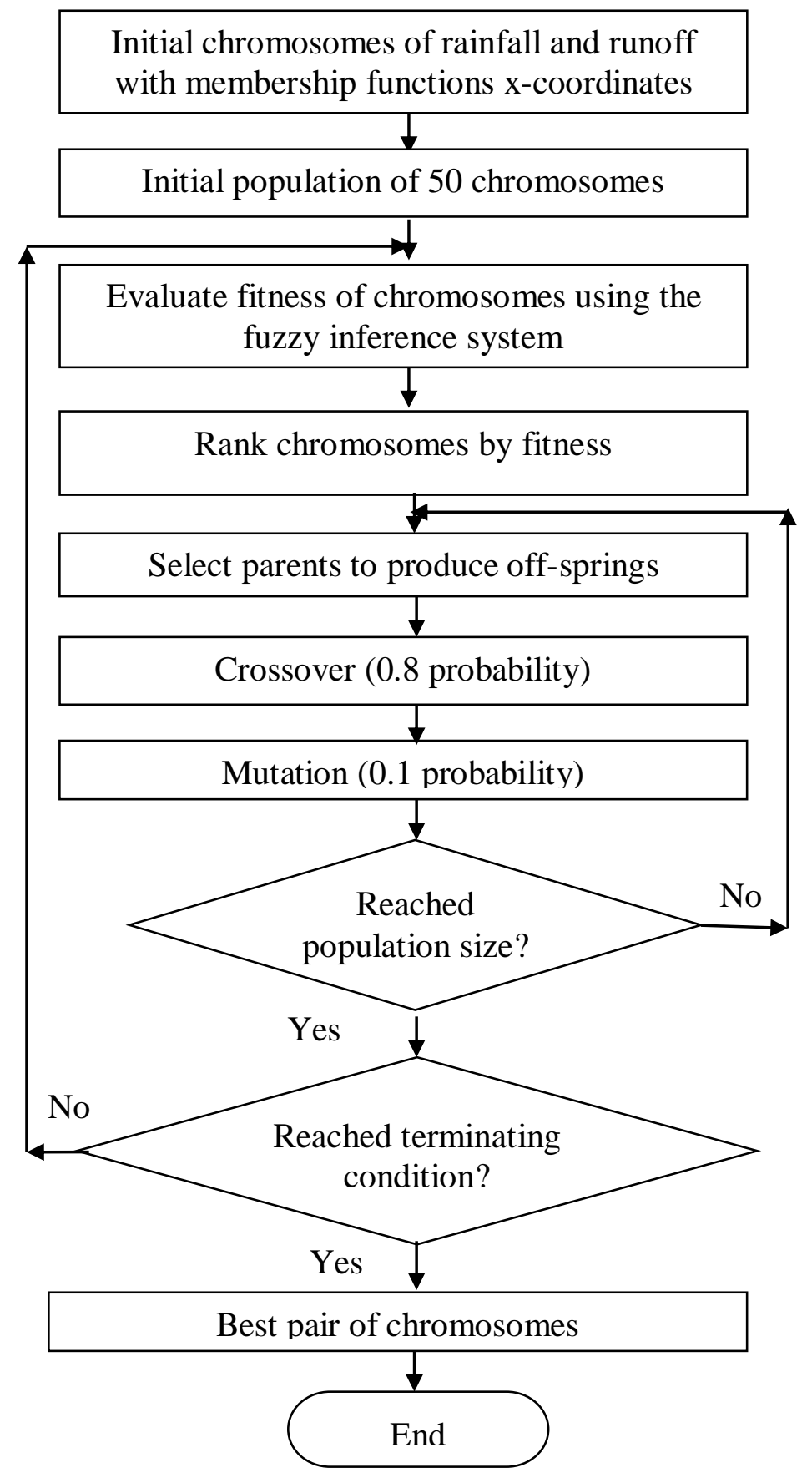

Fig. 5.2. Program flow of the geno-fuzzy model. 

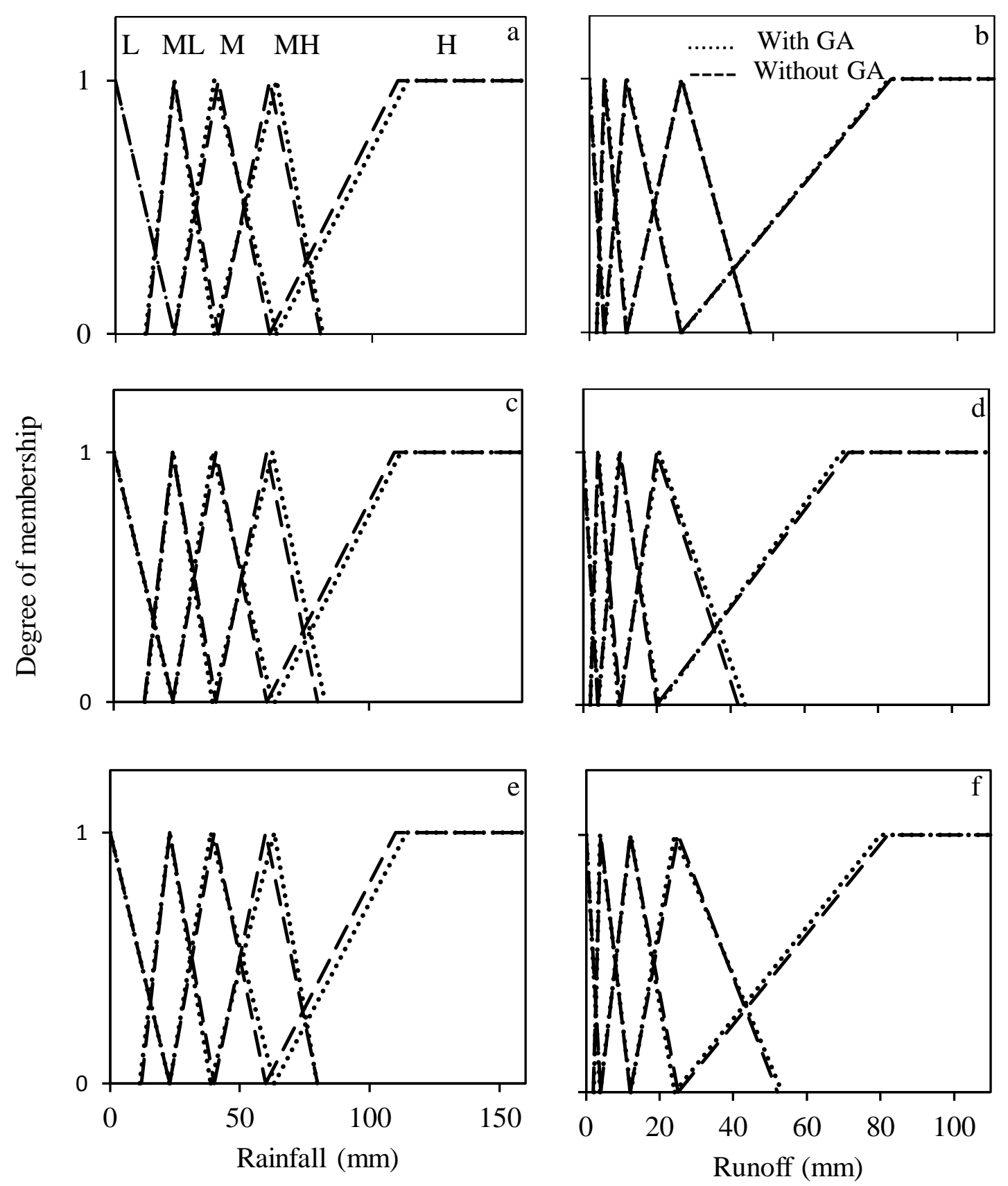

Fig. 5.3. Membership functions with and without genetic algorithm optimization for input variable "Rainfall" and for output variable "Runoff" used for fuzzy inference system for pre-buffer (a and b), post-buffer agroforestry (c and d) and post-buffer contour grass (e and f) watershed simulations. Data labels represent membership functions: L- low, ML- medium low, M-medium, MH- medium high and H- High. 

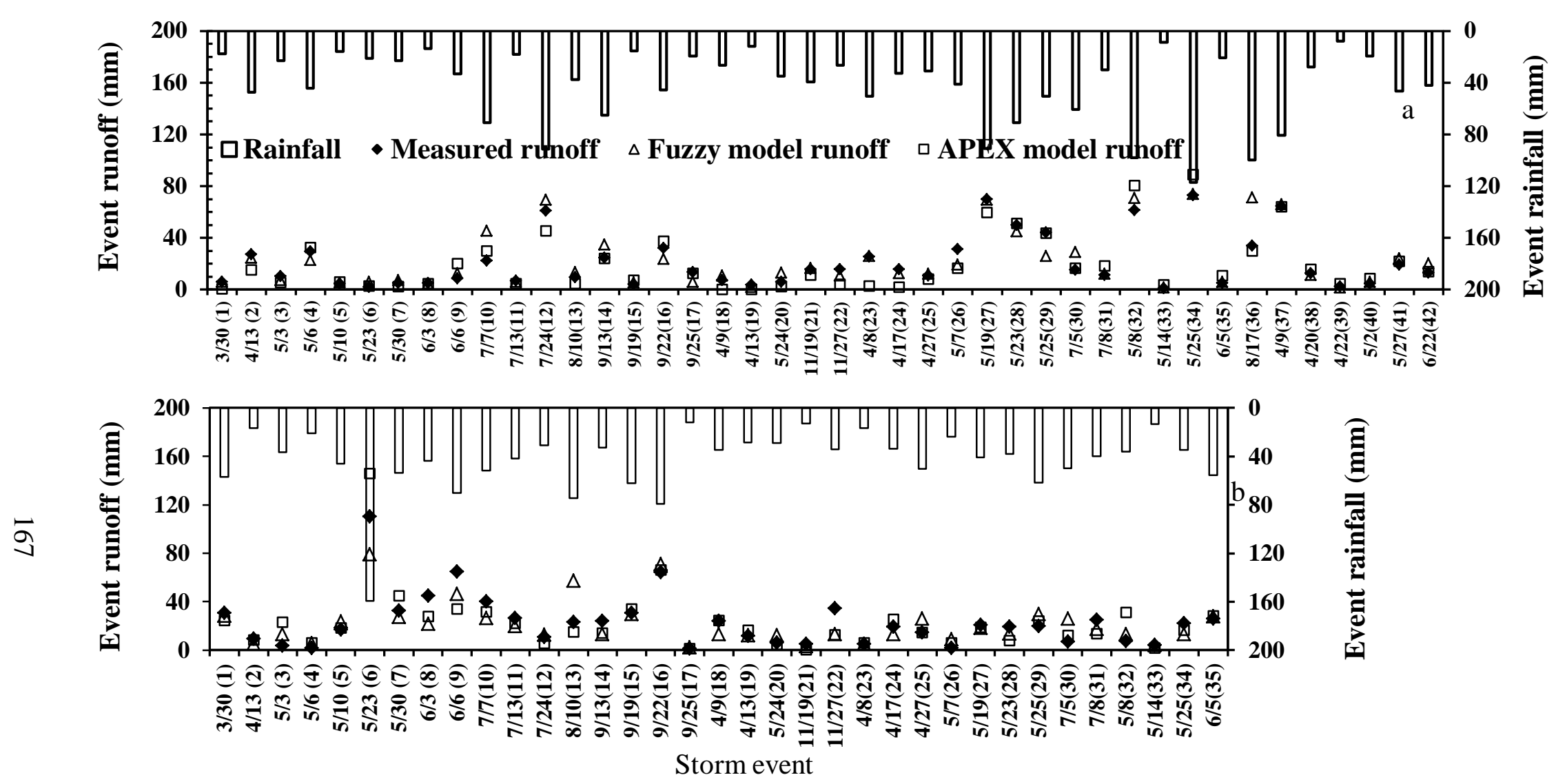

Fig. 5.4. Rainfall, measured event-based runoff, fuzzy logic (FL) and Agricultural Policy Environmental eXtender (APEX) model simulated event-based runoff for Center (a; 1993 to 1997; 42 events) and East (b; 1998 to 2008; 35 events) watersheds without buffers at the paired watershed study, Greenley Research Center, Missouri, USA. The Center (a) watershed shows the results for calibration while East (b) watershed shows the results for validation. 


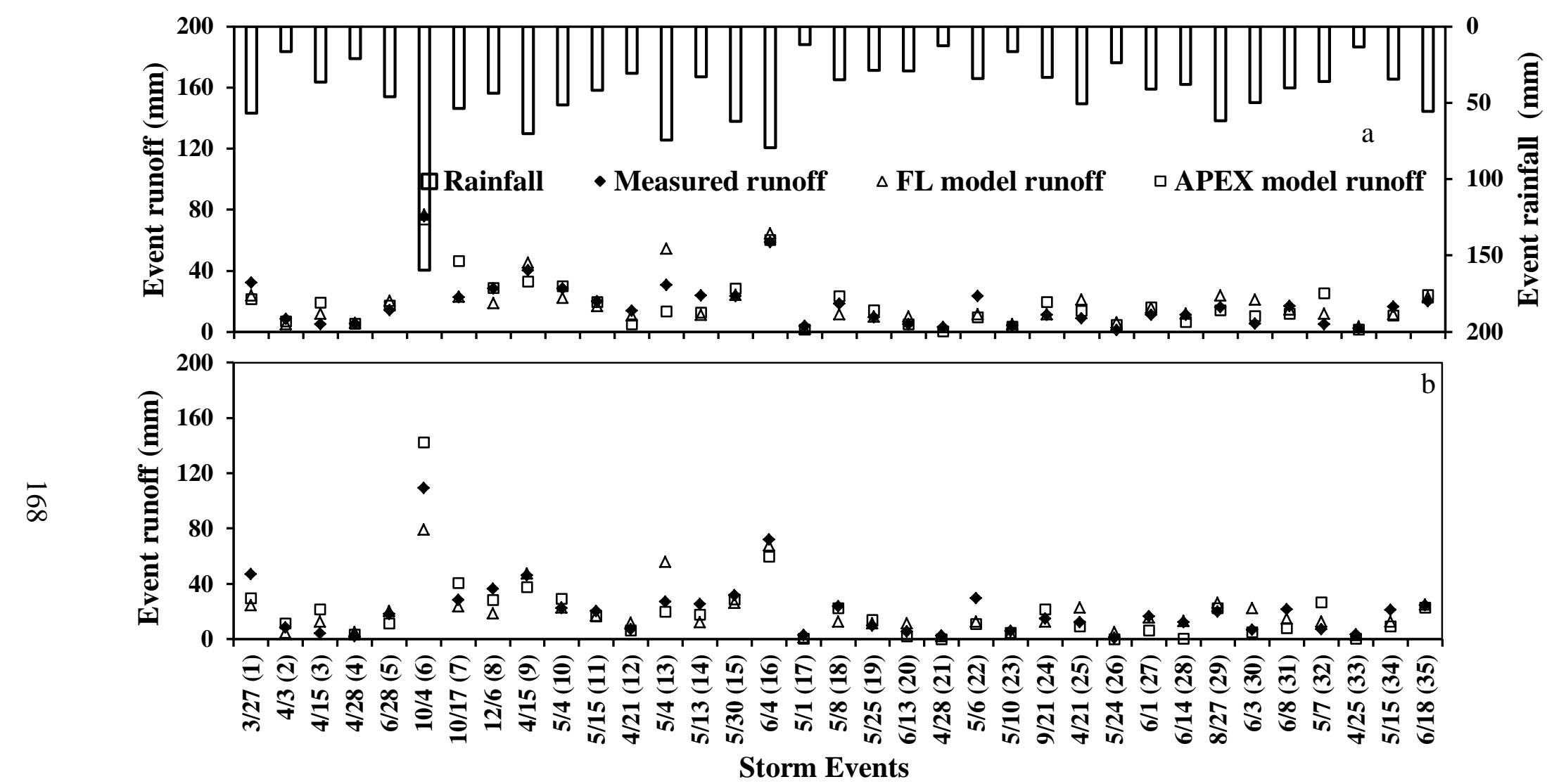

Fig. 5.5. Rainfall, measured event-based runoff, fuzzy logic (FL) and Agricultural Policy Environmental eXtender (APEX) model simulated event-based runoff for Center (a) and West (b) watersheds with agroforestry and contour grass buffers, respectively, at the paired watershed study, Greenley Research Center, Missouri, USA. Storm events 1 to 17 (1998 to 2001) were used for the calibration and events 18 to 35 (2002 to 2008) were used for validation for both watersheds. 

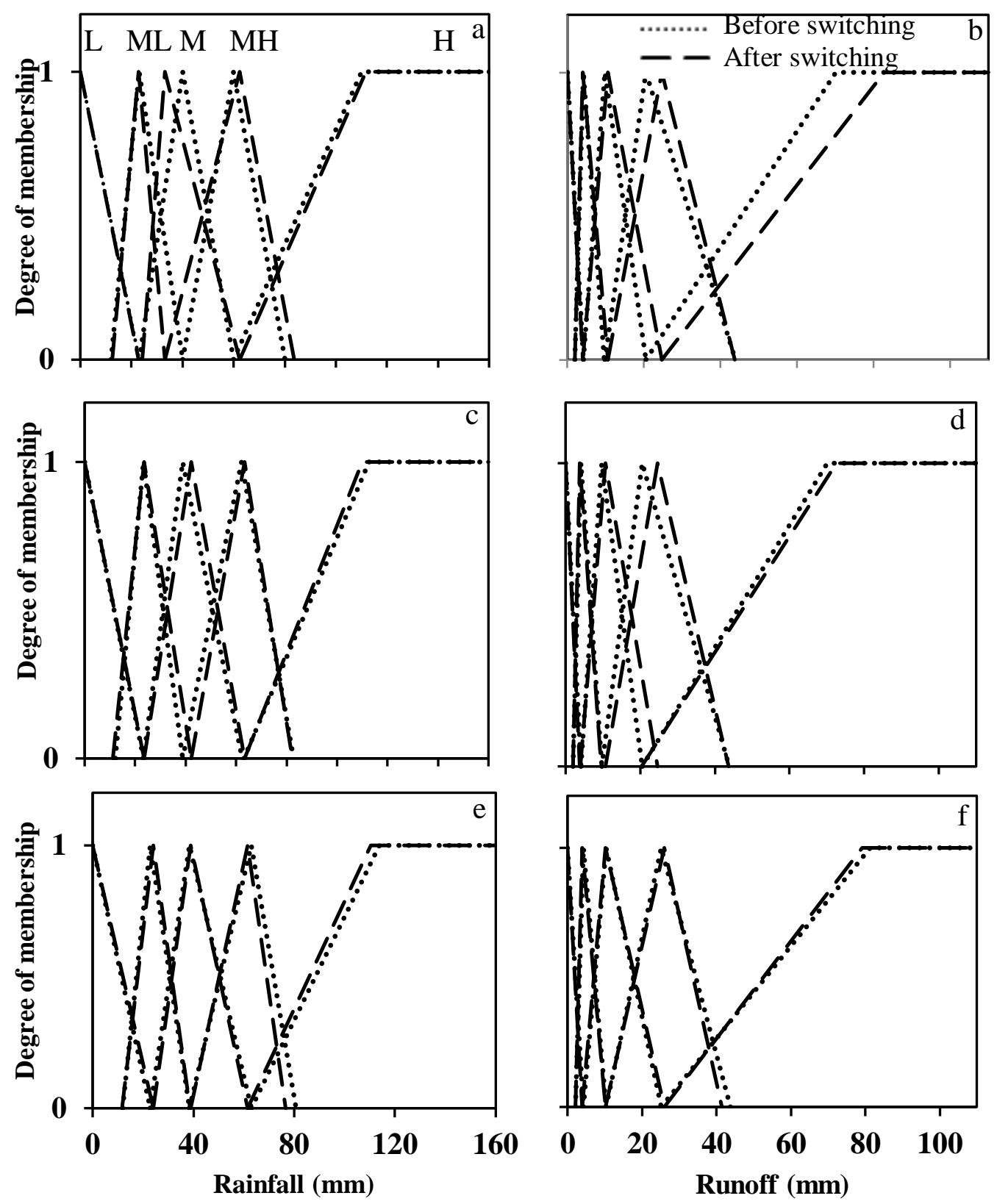

Fig. 5.6. Membership functions with and without genetic algorithm optimization for input variable "Rainfall" and for output variable "Runoff" used for fuzzy inference system for pre-buffer ( $a$ and b), post-buffer agroforestry (c and d) and post-buffer contour grass (e and f) watersheds when calibration and validation data were switched. Data labels represent membership functions: L- low, MLmedium low, M-medium, MH- medium high and H- High. 


\title{
6. CHAPTER
}

\section{MULTI-VARIABLE, MULTI-OBJECTIVE STEPWISE PARAMETER OPTIMIZATION FOR AGRICULTURAL ENVIRONMENTAL POLICY EXTENDER MODEL}

\begin{abstract}
Hydrologic models are widely used for environmental assessments and most need to be calibrated to a degree that is adapted to their use. A good model calibration should assign appropriate values to the model parameters so the model could simulate the true nature of the system being evaluated. The objective of this study was to develop and evaluate a stepwise progressive parameter optimization technique with minimal computational cost for parameter optimization of the Agricultural Environmental Policy and eXtender (APEX) model for runoff, sediment, total phosphorous (TP) and total nitrogen (TN) loading. Twenty three parameters and their ranges for calibration were determined based on the previous simulation work on three adjacent row-crop field-size watersheds located in Northeast Missouri with long-term data. A notebook computer (2.2 GHz, 4GB RAM) and MATLAB code were used to create the automated system to: create a parameter sample population, execute the APEX model for each set of parameters, process the output files to compare calculated outputs with measured values to obtain multi-objective multi-variable functions, and calibrate the model. The objective functions were based on Generalized Likelihood Uncertainty Estimation (GLUE), and combinations of coefficient of determination $\left(r^{2}\right)$,
\end{abstract}


slope and Nash Sutcliff coefficient (NSC), were evaluated for their relative applicability. Parameters sensitive for each output, runoff (5), sediment (5), biological soil properties (4), TP (4) and TN (5) were grouped and used separately to optimize the model in a consecutive manner so that each set of parameters progressively optimize the model. The values of each parameter were limited from two to nine discreet values per parameter to reduce the number of parameter combinations for model runs. Runoff predictions were not affected by the optimization. However, runoff parameter optimization, with objective function that include sediment, and nutrient variable resulted in $31 \%, 7 \%$ and $14 \%$ increases in $r^{2}$ values for sediment, TP, and $\mathrm{TN}$, respectively, compared to the manual calibration values of the previous study. The increases in NSC values after runoff optimization for respective parameters were $3 \%$, $7 \%$, and 9\%. The largest improvements in NSC values were observed for TP after optimization for soil biological (15\%) and P parameters (25\%). The Percent bias values for TP improved by 5 times with $\mathrm{P}$ parameter optimization. The objective function based on the GLUE approach selected the optimum parameter set or close to it for all output variables except for sediment; the objective function based on $r^{2}$, slope and NSC gave the best selection. Step-wise parameter optimization after initial manual model calibration proved to offer an attractive technique for automatic calibration and validation of the APEX model with minimum computational cost.

\section{Introduction}

Conducting in situ experiments at a watershed scale for assessing the benefits of best management practices on reduction of non-point source pollution (NPSP) from 
agricultural watersheds has become overly expensive and complex while physicallybased distributed hydrologic models have been identified as useful and efficient alternatives. Since models are an approximation of reality and are based on many assumptions of input data, the inherent uncertainty of the models will influence their predictions (Heuvelink, 1998). Physically-based models rely on mathematical equations applied in a spatially distributed model domain, and parameter values that are derived from catchment characteristics. These parameters should be held within a realistic uncertainty range (Arnold et al., 2012). Owing to the limitations in measurements and issues related to the scale, hydrologic models often contain parameters that cannot be measured directly and needed to be estimated through a trial-and-error process that adjusts the parameter values to match the model's response to the observed data (Beven, 2001).

Model calibration and validation is the process of demonstrating the ability of a model to simulate watersheds with sufficient accuracy (Moriasi et al., 2007). The initial step of the calibration process is the identification of most sensitive model parameters for a given watershed (Wang et al., 2005; Arnold et al., 2012). Rigorous parameterization and calibration of physically-based models are needed to assure the robustness of the model. Blasone et al. (2008) cautioned that over parameterization could lower the degree of reliability of the model predictions and suggested that the dimensions of the parameter space could be reduced by conducting sensitivity analyses (SA) on model outputs. According to Crosetto et al. (2000), the sensitivity analysis is a prerequisite for model building. The model sensitivity analysis determines the rate of 
change in the model output with respect to the changes in model inputs (Moriasi et al., 2007). The sensitivity analysis helps to identify the non-responsive parameters, which can be fixed to their prior values and thus reduces the number of parameters for calibration (Muleta and Nicklow, 2005). Refsgaard (1997) insisted that parameter values should be justified by field data as much as possible and limit the parameter space to simplify the calibration process. Generally, parameter sensitivity analysis is performed by identifying parameters that are sensitive for key processes and then determining the precision required for the calibration (Arnold et al., 2012).

Sensitivity analysis is conducted either locally where parameters are changed one at a time or globally where all parameters are allowed to change simultaneously. In the one at a time parameter change method, a single parameter is changed while values of all the other parameters are kept fixed. The effects of interdependencies among the parameters cannot be evaluated in this method (Arnold et al., 2012). The above parameter adjustments for models were practiced prior to the advent of high processing power computers through a manual trial and error procedure utilizing the knowledge of the watershed and experience of the hydrologists (Gupta et al., 1999). This method of calibration is also subjective and labor intensive. The global sensitivity analysis on the other hand requires a large number of simulations. Automatic calibration coupled with global optimization algorithms can efficiently and effectively search for parameter combinations/solutions to optimize an objective function that measures the agreement between observed and model predicted values (Gupta et al., 1998). 
Gupta and Sorooshian (1998) stated that the automatic process can provide more objectivity and reduce the need for expertise for the particular model. One major drawback of automatic calibration for physically-based models is the computational cost associated with a large number of model runs that are required to assess the uncertainty owing to their larger number and dimensionality of the parameter space (Blasone et al., 2008). In addition, Arnold et al. (2012) have stressed the importance of keeping model parameters within a realistic uncertainty range as no automatic procedure can be substituted for actual physical knowledge of the watershed. Similarly, Pechlivanidis et al. (2011) recognized that automatic calibration methods have not yet matured to the point that they can entirely replace manual methods due to the difficulty of constructing objective functions and optimization algorithms which replicate human judgment and high computational requirement. They are also with the view that automatic methods are often most successful when used in conjunction with a manual procedure. To that effect, Abbaspour et al. (2007) developed a semi-automated interactive system: Sequential Uncertainty FItting Ver. 2 (SUFI2), using both manual and automated calibration techniques for Soil Water Assessment Tool (SWAT) model, incorporating sensitivity and uncertainty analysis.

The models need to be optimized for multiple objectives of multiple output variables (flow, sediment, and nutrients; Gupta and Sorooshian, 1998; Gupta et al., 1998, 1999). It has also been emphasized that the model should be validated not only on time but also on multi sites (Blasone et al., 2008) and also at different scales to find any dependency of processes on modeling scale (Vazquez et al., 2002; Vazquez and Feyen, 
2007). Recently, automated calibration methods, with multi-objective functions implemented using high speed computers have become more popular (Gupta et al., 1998, 1999; vanGriensven et al., 2006; Zhang et al., 2009; Vrugt et al., 2009).

The generalized likelihood uncertainty estimation (GLUE) method proposed by Beven and Binley (1992) is widely used for automatic calibration processes and is also known for efficient representation of uncertainty in the calibrated model as well as in the model responses (Muleta and Nicklow, 2005; Wang et al., 2005; Ratto et al., 2007; Blasone et al., 2008). The GLUE procedure requires a large number of simulations with different parameter sets chosen randomly from a specified distribution.

Wang et al. (2005) compared variance-based sensitivity analysis and the Morris measure for parameter sensitivity analysis in order to identify the most influential parameters of the APEX model. The variance-based sensitivity analysis estimates the fractional contribution of each parameter to the total variance of the model output while the Morris measure calculates the total and interaction effects. Though the variancebased analysis was found to be very reliable, its high computational cost has encouraged selection of the enhanced version of the Morris method which has produced reasonable results for the national Conservation Effects Assessment Project (CEAP). However these researchers have not used the sensitivity analysis in combination with an automated system for automatic calibration process for the APEX model. Zhang et al. (2009) compared several methods: genetic algorithm, shuffled complex evolution, particle swarm optimization, differential evolution, and artificial immune system 
optimization for the Soil Water Assessment Tool (SWAT) model. The genetic algorithm produced the best combination of objective values with a large number of model runs, followed by differential evolution, shuffled complex evolution, particle smarm optimization, and artificial immune system. They suggested that for computationally intensive models, the number of model evaluations needed to obtain acceptable objective values is the deciding factors when selecting an optimizing algorithm. Accordingly, an algorithm should be selected that could find acceptable objective values within a limited number of evaluations (less than 1000).

The data requirement often becomes an obstacle for a proper validation especially; availability of all the variables is rare. Due to this reason, most distributed models have usually been calibrated and validated only against discharge data (McMichael et al., 2006; Engeland et al., 2006). The current study uses long-term data available for runoff, sediment, TN, and TP loadings from a unique watershed study with three adjacent watersheds (Fig. 6.1, West, Center and East) with row-crop management in the claypan region of Northeast Missouri (Udawatta et al., 2002). Senaviratne et al. (2013) conducted a manual sensitivity analysis, calibration and validation of the APEX model for event-based runoff, sediment, TP, and TN losses from these watersheds. The manual sensitivity analysis and calibration were carried out with model performance coefficients: $r^{2}$ values ranging 0.34 to 94 , NSC values ranging 0.18 to 0.87 , and Pbias ranging $0.95 \%$ to $67.63 \%$.

The main goal of this study was to further refine the model simulation and 
determine the optimal parameter set for the APEX model by Senaviratne et al. (2013), using a multi-objective multi-variable global automatic optimization method. The sub objectives of the study were to: (1) develop a stepwise parameter optimization method with minimal computational costs for automatic calibration of the APEX model for runoff, sediment, TP, and TN loadings of the study watersheds, (2) use the automated system to calibrate the model using the center watershed data, (3) compare these values with the manually optimized model for the same watershed, and (4) validate the model using West and East watershed data. The generalized likelihood uncertainty estimation (GLUE) method proposed by Beven and Binley (1992) is widely used for automatic calibration processes and is also known for efficient representation of the uncertainty in the calibrated model and the resultant model responses (Muleta and Nicklow, 2005; Wang et al., 2005; Ratto et al., 2007; Blasone et al., 2008). The GLUE procedure requires a large number of simulations with different parameter sets chosen randomly from a specified distribution.

Wang et al. (2005) compared variance-based sensitivity analysis and the Morris measure for parameter sensitivity analysis in order to identify the most influential parameters of the Agricultural Environmental Policy and eXtender (APEX) model. The variance-based sensitivity analysis estimates the fractional contribution of each parameter to the total variance of the model output while the Morris measure calculates the total and interaction effects. Though the variance-based analysis was found to be very reliable, its high computational cost has encouraged the selection of the enhanced version of the Morris method which has produced reasonable results for the national 
Conservation Effects Assessment Project (CEAP). However, these researchers have not used the sensitivity analysis in combination with an automated system for automatic calibration process for the APEX model. Zhang et al. (2009) compared several methods: genetic algorithm, shuffled complex evolution, particle swarm optimization, differential evolution, and artificial immune system optimization for the parameter optimization and automatic calibration of the SWAT model. The genetic algorithm produced the best combination of objective functions with a large number of model runs, followed by differential evolution, shuffled complex evolution, particle smarm optimization, and artificial immune system. They suggested that for computationally intensive models, the number of model evaluations needed to obtain acceptable objective function values is the deciding factor on an optimizing algorithm. According to them, an algorithm should be selected that can find acceptable objective function values within a limited number of evaluations (less than 1000).

The data requirement often becomes an obstacle for a proper validation: availability of all the variables is rare. Consequently, many distributed models have been calibrated and validated only against discharge data (McMichael et al., 2006; Engeland et al., 2006) even when the intended use was to assess water quality. The current study uses long-term data available for runoff, sediment, TN, and TP loadings from a unique watershed study with three adjacent watersheds (Fig. 6.1, West, Center and East) with row-crop management in the claypan region of Northeast Missouri (Udawatta et al., 2002). Senaviratne et al. (2013) conducted a manual sensitivity analysis, calibration and validation of the APEX model for event-based runoff, 
sediment, TP, and TN losses from these watersheds. The manual sensitivity analysis and calibration were carried out with model performance coefficients $r^{2}$ values ranging 0.34 to 0.94 , NSC values ranging 0.18 to 0.87 , and Pbias ranging $1 \%$ to $67 \%$.

The main goal of this study was to further refine the model simulations by Senaviratne et al. (2013) and to find the optimal parameter set for the APEX model, using a multi-objective, multi-variable global automatic optimization and calibration method. The sub objectives of the study were to: (1) develop a stepwise parameter optimization method with minimal computational costs for automatic calibration of the APEX model for runoff, sediment, TP, and TN loadings of the study watersheds, (2) use the automated system to calibrate the model using the center watershed data, (3) compare these values with the manually optimized model for the same watershed, and (4) validate the model using West and East watershed data.

\section{Materials and Methods}

\section{The study watersheds and APEX model simulations}

The study watersheds were established in early 1991 at the University of Missouri Greenley Memorial Research Center in Knox County, Missouri, USA $\left(40^{\circ} 01^{\prime}\right.$ N, 92 $11^{\prime} \mathrm{W}$; Udawatta et al., 2002). Three adjacent north-facing no-till corn-soybean (Zea mays L.- Glycine max (L.) watersheds (East-1.65 ha, Center-4.44 ha, and West3.16 ha; Fig. 6.1a) in the Central Claypan region (USDA-NRCS MLRA 113) were sampled for a six year calibration period (before the establishment of upland contour agroforestry and grass buffers) with grass waterways (fescue grass [Schedonorus 
phoenix (Scop.) Holub]). This study was a continuation of the APEX model calibration and validation study using manual parameter sensitivity analysis and optimization and further details of it can be found in Senaviratne et al. (2013). The input files created in the previous study was used as the baseline inputs to the APEX model in the current study. The model options selected for the key hydrological processes for this study are given in Table 6.1 (Senaviratne et al., 2013).

\section{Global parameter optimization and calibration}

The most common parameters optimized for calibration of the APEX model are contained in input files: control, subarea, soil, operational schedule, and parameter. The parameters in the control, subarea, operation, and soil file are determined based on topography, land use, soil, and management operation details. The parameters in the parameter file consist of coefficients of the model equations used to simulate the watershed hydrology and plant growth and the optimal values should be determined through the process of calibration. Therefore the parameters considered for optimization were selected only from the parameter file. In order to reduce the number of model runs, each parameter range was limited and divided into two to nine discrete values based on the previous findings and the APEX user manual (Williams et al., 2008). Parameters were grouped based on their direct impact on runoff, sediment, biological activity, TP, and TN (Table 6.2). Then each group was separately and consecutively used for optimization. All possible combinations of values of each group of parameters were used for the optimization and calibration of the model. The following three options were evaluated for the multi-objective, multi-variable function: 
1) Generalized likelihood uncertainty estimation (GLUE; Beven and Binley, 1992; Aronica et al., 1998; Wang et al., 2005). In this method a likelihood measure $(L)$ was calculated for each set of parameters and the best combination was selected by the goodness of fit model performance equations used by Wang et al. (2005).

$$
L\left(\theta_{i} \mid O\right)=\exp \left(-\frac{M S E_{i}}{\min (M S E)}\right), i=1,2,3, \ldots \ldots N \ldots \ldots \ldots \ldots \ldots \ldots . . . \text { Eq. 6.1] }
$$

where, $L$ of each model run corresponds to $i^{\text {th }}$ set of parameters $\left(\theta_{i}\right)$. $O$ corresponds to observation vector, $\left(O_{1}, O_{2,} O_{3} \ldots \ldots \ldots . . O_{T}\right), N$ is total number of simulations, $M S E_{i}$ is the mean squared error for the $i$ th model run, and $\min (M S E)$ is the overall minimum $M S E$ of total $N$ simulations. The $M S E_{i}$ is calculated as:

$$
M S E_{i}=\frac{1}{T} \sum_{t=1}^{T}\left(P_{t}-O_{t}\right)^{2}
$$

where, $T$ is the number of observations available, $P_{t}$ is the predicted value and $O_{t}$ is the observed value for the same event.

The multi-objective function $\left(f_{i}\right)$ was based on the square of the likelihood measures for each variable calculated using $0.3,0.25,0.2$ and 0.25 likelihood weights for runoff, sediment, TP, and TN, respectively;

$f\left(\theta_{i} \mid O\right)$

$=\left[0.3 \times L\left(\theta_{i} \mid \text { Runoff }\right)^{2}\right.$

$\left.+0.25 \times L\left(\theta_{i} \mid \text { Sediment }\right)^{2}+0.2 \times L\left(\theta_{i} \mid T P\right)^{2}+0.25 \times L\left(\theta_{i} \mid T N\right)^{2}\right]^{1 / 2} \ldots[$ Eq. 6.3] where, $L\left(\theta_{i} \mid\right.$ Runoff $), L\left(\theta_{i} \mid\right.$ Sediment $), L\left(\theta_{i} \mid T P\right)$, and $L\left(\theta_{i} \mid T N\right)$ are the likelihood values calculated according to the Eq. 6.1. The likelihood weights were decided based on the findings of manual calibration (Senaviratne et al., 2013) with 
the emphasis to improve the goodness of fit values for poorly calibrated outputs such as sediment and TN. Gupta et al. (1998) stated that assigning weights was always subjective and must be decided by the modeler considering what important characteristics of watershed behavior need to be reproduced by which model output for the calibrated model.

2) Multi-objective function $\left(f_{i}\right)$ using mean of the product of slope of regression line times coefficient of determination $\left(r^{2}\right)$ for runoff, sediment, TP and TN:

$$
f_{i=1}^{N}\left(\theta_{i} \mid O\right)=\operatorname{Mean}\left(\theta_{i} \mid O\right)\left(r_{v}^{2} \times \text { slope }_{v}\right), v=1,2,3, \ldots \ldots . \ldots \ldots \ldots \ldots[\text { Eq. 6.4] }
$$

where, multi-objective function, $\left(f_{i}\right)$ of each model run corresponds to $i^{\text {th }}$ set of parameters $\left(\theta_{i}\right) . O$ corresponds to observation vector $\left(O_{1}, O_{2,,} O_{3 \ldots \ldots \ldots . .} O_{T}\right)$, and $N$ is total number of simulations, Mean $\left(\theta_{i} \mid O\right)$ calculates the average of $r^{2} \mathrm{x}$ slope for $V$ number of variables (e.g. runoff, sediments, TP, and TN) for $i^{\text {th }}$ model run

3) Multi-objective function $\left(f_{i}\right)$ using means of (slope $\mathrm{x} r^{2}$ ) and NSC of output variables

$$
\begin{aligned}
& f_{i=1}^{N}\left(\theta_{i} \mid O\right)=\frac{1}{2}\left(\operatorname{Mean}\left(\theta_{i} \mid O\right)\left(r_{v}^{2} x \operatorname{slope}_{v}\right)+\operatorname{mean}\left(\theta_{i} \mid O\right)\left(N S C_{v}\right),\right. \\
& v=1,2,3, \ldots . . V
\end{aligned}
$$

where, multi-objective function, $\left(f_{i}\right)$ of each model run corresponds to $i^{\text {th }}$ set of parameters $\left(\theta_{i}\right) . O$ corresponds to observation vector $\left(O_{1}, O_{2}, O_{3 \ldots \ldots \ldots .} O_{T}\right)$, and $N$ is total number of simulations. The $f_{i}$ averages the means of $r^{2} \mathrm{x}$ slope and NSC values for $V$ of variables, i.e., runoff, sediment, TP, and $\mathrm{TN}$, for $i^{\text {th }}$ model run.

MATLAB 7.10.0. software was used to develop the automatic calibration system for the APEX model using multi-objective, multi-variable parameter optimization. The 
Fig. 6.2 illustrates the program flow of the multi-objective, multi-variable stepwise parameter optimization and calibration module for the APEX model. The code consisted of modules to:

1. Create sample population of parameter sets containing all possible combinations of possible values (Table 6.2) for each parameter in each group: runoff, sediment, soil biological processes, TP, and TN.

2. Update the parameter file of the model with each sample set, and execute the model.

3. Process the daily watershed output files to estimate the simulated event runoff, sediment, TP, and TN values corresponding to the observed event values.

4. Calculate multi-objective function values for each parameter set. The parameter set corresponding to the largest value of the multi-objective function was selected as the optimum set

5. Update the parameter file with the optimum set for the parameter group considered and repeat the process for the next parameter group.

In order to get the intermediate optimization results at each progressive optimization by each group of parameters, the program was stopped at steps four using manual breaks. The corresponding multi-variable, multi-objective performance indicators for all parameter combinations in each group of parameters were recorded in an Excel sheet to compare different multi-objective functions with the visual observations. The visual observation on desirable model performance indicators for output variables mainly focused on optimizing the performance indicators of $\mathrm{TN}$ as it was the most poorly calibrated variable in the manual method. The parameter file with 
the final set of optimum parameters was used for the model validation with West and East watersheds.

\section{Results and Discussion}

\section{Multi-variable multi-objective function}

The model performance for each of the three possible multi-variable, multiobjective functions along with the visual observation of optimum parameter set is given in Table 6.3. Each row contains the performance indicators for output variables: runoff, sediment, TP, and TN, of the optimal set selected by respective objective functions and independent observations after each step of progressive optimization by the different parameter groups: runoff, sediment, soil biological processes, TP, and TN. All objective functions closely selected the optimal parameter sets for runoff. On the other hand, none of the objective functions identified the optimal parameter set for sediment according to visual observation but the objective function using slope, $r^{2}$, and NSC (Eq. 6.5) selected the best set compared to the GLUE and slope and $r^{2}$ based objective functions. The GLUE based objective function identified the optimal parameter sets for TP and TN better than the other two functions and similar to visual observations. The method using

slope and $r^{2}$ did not select the optimal parameter sets for any of the variables. White and Chaubey (2005) used multi-objective functions comprising percent relative error, $r^{2}$, and NSC values to find the optimal parameter set with automatic calibration for the Soil Water Assessment Tool (SWAT) for flow, sediment, TP, and nitrate-N plus nitrite-N.

The success of the GLUE method in recent studies has been attributed to its 
capability of assessing the global uncertainty present in the various modeling elements in a computationally simple way (Kuczera and Parent, 1998; Aronica et al., 2002; Muleta and Nicklow, 2005; Ratto et al., 2007; Blasone et al., 2008). The common setbacks reported for the GLUE method were the huge number of necessary model simulations and that when the initial sampling of the parameter space scheme was not dense enough, the usual sampling techniques such as Monte Carlo scheme or the Latin hypercube sampling cannot ensure sufficient accuracy (McMichael et al., 2006).

Blasone et al. (2008) used the initial sensitivity analysis to reduce the parameter space before using GLUE with shuffled complex evolution metropolis (SCEM-UA) sampling method for uncertainty assessment and parameter optimization of the MIKESHE model. The use of manual sensitivity analysis to limit the parameter space and the stepwise parameter optimization technique in the current study did satisfactorily reduce the number of runs required to less than 1100 per each step (Table 6.3) while producing reasonable model performances with multi-variable, multi-objective functions based on the GLUE technique.

\section{Stepwise parameter optimization}

Figure 6.3 depicts the progress of the model performance indices for $r^{2}$ (a), NSC (b), and Pbias (c) for the stepwise parameter optimization and calibration process of the APEX model. The model performance indicators of the manual sensitivity analysis and optimization (Senaviratne et al., 2013) were used as the baseline values to compare progressive changes in the current simulations. Model performances for runoff were not 
affected by any of the steps in parameter optimization but performance for each of the other outputs, i.e., sediment, TP, and TN loadings, improved after stepwise parameter optimization. The $r^{2}$ values for sediment, TP, and TN loadings improved by $31 \%, 8 \%$, and $16 \%$ compared to the baseline values, respectively, after the model was optimized for runoff parameters alone. The subsequent steps of parameter optimizations did not result in further improvements of $r^{2}$ values for any of the output variables. This emphasizes the importance of optimization of model parameters for runoff to improve the model performance indices of all other pollutant loadings, even when runoff simulations do not appear to improve.

The changes in NSC values were $3 \%, 7 \%$, and $9 \%$ for sediment, TP and TN loadings after runoff parameter optimization. Subsequent steps of parameter optimization did not change the NSC values in sediment and TN loadings. However NSC values of TP were greatly increased by $15 \%$ and $25 \%$ after the parameter optimizations for soil biological activity and $\mathrm{P}$ processes, respectively. The highest fluctuations in Pbias values were shown by TP which was significantly and gradually reduced to $6 \%$ from the baseline value of $32 \%$ due to parameter optimization for biological activity and $\mathrm{P}$ processes. The highest improvement in Pbias was found after the P parameter optimization of the model.

The results show that the values of optimal parameter sets found varied among the different objective functions (Table 6.4). Gupta et al. (1998) stated that different sets of objective functions may result in different optimal parameter sets for a model when 
model performance was evaluated. Samanta and Mackay (2003) attributed this behavior to the compensation of model parameters by each other. Beven and Binley (1992) stated that there are many different catchment hydrological processes such as infiltration, overland flow, subsurface flow, interflow etc., which are not mutually exclusive and can occur simultaneously or consecutively. Therefore, the hydrological model responses such as runoff should be based on the combination all of these mechanisms. The model responses of sediment and nutrient loadings also clearly depend on these primary processes. Various combinations of these mechanisms can result in different permutations of optimal parameter sets. In an answer to 'How to identify the correct set' they suggest that the hydrologist must use their experience or identify a particular parameter set based on previous findings. In this study, the selection of limited sets of parameters with a limited set of discrete values was the key to the satisfactory parameter optimization and calibration of the model. The stepwise optimization also addressed the interactions or the inter-dependencies of processes by the progressive optimization of the model in the order of runoff, sediment, soil biological properties, TP, and TN. This ripple effect was obvious by vast improvements in the $r^{2}$ values for sediment, TP, and TN loadings after optimization of the model for runoff. This could be recognized as a weakness in the manual sensitivity analysis as one tends to proceed blindly to the next level of optimization with the false conception that the model was sufficiently optimized for runoff once good model indices for runoff are obtained. Stepwise optimization also helped in reducing the number of model runs as well as each parameter optimization complimented the subsequent optimizations. 
The prior identification and ranking of the most sensitive model parameters by sensitivity analysis was a pre-requisite for the current automated calibration system to define the optimal set of parameters with the least number of runs. Francos et al. (2003) also used a two step process to minimize the number of model runs needed to find the optimal parameter set. During the first step, the whole set of input parameters was screened and ranked with a relatively low computational cost, and during the second step, a Fourier amplitude sensitivity test (FAST) technique was applied to the most relevant parameters to quantify their relative sensitivities to the model outputs. The stepwise optimization and automatic calibration method described in this study also could be used including all parameters if prior sensitivity analysis was not done, by grouping them according to manageable groups based on their impact on output variables.

\section{Validation of the model}

The model calibrated for the Center watershed event-based data using the automatic parameter optimization and calibration was validated with event-based data from West and East watersheds and the resultant model performances were compared with the manual model validations from the previous study as shown in Table 6.4. The model performance indicators improved for runoff of both West and East watersheds. East watershed simulation for runoff improved more than the West watershed compared to the manually optimized model. Model performance for validation of the model for sediment greatly improved in all indicators for both West and East watersheds. The $r^{2}$ and NSC values were over 0.9 for event-sediment loadings for West watershed better 
than the Center watershed for which the model was calibrated. The performance indicators for validation of TP improved significantly especially the NSC values for both West and East watersheds compared to those of the manual calibration study. The performance indicators for model validation of TN also improved in $r^{2}$ values but the increase in NSC values were not so large.

\section{Conclusions}

An output variable based, stepwise, multi-variable and multi-objective function parameter optimization and automatic calibration of the physically-based APEX model was carried out for three adjacent row-crop field-size watersheds located in Northeast of Missouri for event-based runoff, sediment, TN, and TP. The parameter sets belonging to each group of stepwise optimization: runoff, sediment, soil biological activity, TP, and $\mathrm{TN}$, and their spaces were selected based on previous findings of a manual sensitivity analysis and the user manual. The optimization of the model was carried out with groups of parameters in the order of runoff, sediment, soil biological activities, TP and TN. Several objective functions were evaluated for the selection of optimal parameter sets. The objective function based on the GLUE method which selected the optimum parameter set or close to it for all output variables except for sediment for which the objective function based on $r^{2}$, slope and NSC gave the best selection. The model performance for runoff was not affected by any of the parameter optimization techniques compared with the baseline values. However, optimization for runoff parameters produced significant improvements in sediment predictions with a $31 \%$ increase in $r^{2}$ values compared to the manual baseline values. The $r^{2}$ values of TP and 
TN also improved by $7 \%$ and $14 \%$, respectively. The NSC values were increased by $3 \%, 7 \%$ and $9 \%$ for sediment, $\mathrm{TP}$ and $\mathrm{TN}$, respectively after parameter optimization for runoff. The only other improvements were observed for NSC and Pbias values for TP. The NSC values were increased by $15 \%$ and $25 \%$ by the optimization of biological and P parameters, respectively.

The Pbias values for TP showed large fluctuations and were reduced to $6 \%$ from $32 \%$. The validation of the calibrated model by West and East watersheds showed considerable improvements in model performances. The largest improvements were observed for the East watershed for runoff and the West watershed for sediment. The study concludes that parameter optimization for runoff was the key for the subsequently improved simulations of sediment, TP, and TN. Manual sensitivity analysis was helpful to screen out sensitive parameters and determine their sensitive spaces to reduce the number of runs needed for automatic calibration. A reduced number of parameters and limited set of values coupled with stepwise optimization offered a less computer intensive and affordable global optimization method for model calibration of the APEX model. The current study only considered the parameters listed in the parameter files of the APEX model. Hence, future research on parameter optimization may consider other parameters listed in subarea, soil, operations, and control input files.

\section{List of References}

Abbaspour, K.C., J. Yang, I. Maximov, R. Siber, K. Bogner, J. Mieleitner, J. Zobrist, and R. Srinivasan. 2007. Modelling hydrology and water quality in the prealpine/alpine Thur watershed using SWAT. J. Hydrol. 333(2-4): 413-430. 
Arnold, J.G., D.N. Moriasi, P.W. Gassman, K.C. Abbaspour, M.J. White, R. Srinivasan, C. Santhi, R.D. Harmel, A. van Griensven, M.W. Van Liew, N. Kannan, and M.K. Jha. 2012. SWAT: Model use, calibration, and validation. Trans. ASABE. 55: $1491-1508$.

Aronica, G., B. Hankin, and K. Beven. 1998. Uncertainty and equifinality in calibrating distributed roughness coefficients in a flood propagation model with limited data. Adv. Water Resour. 22(4): 349-365.

Aronica, G., P.D. Bates, and M.S. Horritt. 2002. Assessing the uncertainty in distributed model predictions using observed binary pattern information within GLUE. Hydrol. Process. 16(10): 2001-2016.

Beven, K., and A. Binley. 1992. The future of distributed models: model calibration and uncertainty prediction. Hydrol. Process. 6(3): 279-298.

Beven, K.J. 2001. Dalton Medal Lecture: How far can we go in distributed hydrological modelling? Hydrol. Earth Syst. Sci. 5(1): 1-12.

Blasone, R.S., H. Madsen, and D. Rosbjerg. 2008. Uncertainty assessment of integrated distributed hydrological models using GLUE with Markov chain Monte Carlo sampling. J. Hydrol. 353(1): 18-32.

Crosetto, M., S. Tarantola, and A. Saltelli. 2000. Sensitivity and uncertainty analysis in spatial modelling based on GIS. Agric. Ecosyst. Environ. 81(1): 71-79.

Engeland, K., I. Barud, L. Gottschalk, and E. Leblois. 2006. Multiobjective regional modelling. J. Hydrol. 327(3-4): 339-351.

Francos, A., F.J. Elorza, F. Bouraoui, G. Bidoglio, and L. Galbiati. 2003. Sensitivity analysis of distributed environmental simulation models: understanding the model behaviour in hydrological studies at the catchment scale. Reliab. Eng. Syst. Saf. 79(2): 205-218.

Gupta, H.V., S. Sorooshian, and P.O. Yapo. 1998. Toward improved calibration of hydrologic models: Multiple and noncommensurable measures of information. Water Resour. Res. 34(4): 751-763.

Gupta, H.V., S. Sorooshian, and P.O. Yapo. 1999. Status of automatic calibration for hydrologic models: Comparison with multilevel expert calibration. J. Hydrol. Eng. 4(2): 135-143.

Hargreaves, G.H., and Z.A. Samani. 1985. Reference crop evapo-transpiration from temperature. Applied Eng. Agric. 1: 96-99. 
Heuvelink, G.B.M. 1998. Uncertainty analysis in environmental modelling under a change of spatial scale. Nutr. Cycl. Agroecosystems 50(1): 255-264.

Kuczera, G., and E. Parent. 1998. Monte Carlo assessment of parameter uncertainty in conceptual catchment models: the Metropolis algorithm. J. Hydrol. 211(1-4): 69-85.

McMichael, C.E., A.S. Hope, and H.A. Loaiciga. 2006. Distributed hydrological modeling in California semi-arid shrublands: MIKESHE model calibration and uncertainty estimation. J. Hydrol. 317: 307-324.

Moriasi, D.N., J.G. Arnold, M.W. Van Liew, R.L. Bingner, R.D. Harmel, and T.L. Veith. 2007. Model evaluation guidelines for systematic quantification of accuracy in watershed simulations. Trans. ASABE 50(3): 885-900.

Mudgal, A., C. Baffaut, S.H. Anderson, E.J. Sadler, and A.L. Thompson. 2008. APEX model assessment of variable landscapes on runoff and dissolved herbicides. In ASABE International meeting. June 29 - July 2. Providence, Rhode Island. ASABE publication.

Muleta, M.K., and J.W. Nicklow. 2005. Sensitivity and uncertainty analysis coupled with automatic calibration for a distributed watershed model. J. Hydrol. 306(1): 127-145.

Pechlivanidis, I.G., B.M. Jackson, N.R. Mcintyre, and H.S. Wheater. 2011. Catchment scale hydrological modelling: a review of model types, calibration approaches and uncertainty analysis methods in the context of recent developments in technology and applications. Glob. Nest J. 13(3): 193-214.

Ratto, M., P.C. Young, R. Romanowicz, F. Pappenberger, A. Saltelli, and A. Pagano. 2007. Uncertainty, sensitivity analysis and the role of data based mechanistic modeling in hydrology. Hydrol. Earth Syst. Sci. Discuss. 11(4): 1249-1266.

Refsgaard, J.C. 1997. Parameterisation, calibration and validation of distributed hydrological models. J. Hydrol. 198(1-4): 69-97.

Samanta, S., and D.S. Mackay. 2003. Flexible automated parameterization of hydrologic models using fuzzy logic. Water Resour. Res. 39(1): 1009.

SCS. 1985. Sec. 4, Hydrology. -National Engineering Handbook. U.S. Dept. of Agric. Soil Conservation Service, Washington, D.C.

Senaviratne, G.M.M.M.A., R.P. Udawatta, C. Baffaut, and S.H. Anderson. 2013. Agriculture Policy Environmental eXtender simulation of three adjacent rowcrop watersheds in the claypan region. J. Environ. Qual. In press. 
Udawatta, R.P., J.J. Krstansky, G.S. Henderson, and H.E. Garrett. 2002. Agroforestry practices, runoff, and nutrient loss. J. Environ. Qual. 31(4): 1214-1225.

vanGriensven, A., T. Meixner, S. Grunwald, T. Bishop, M. Diluzio, and R. Srinivasan. 2006. A global sensitivity analysis tool for the parameters of multi-variable catchment models. J. Hydrol. 324(1-4): 10-23.

Vazquez, R.F., and J. Feyen. 2007. Assessment of the effects of DEM gridding on the predictions of basin runoff using MIKE SHE and a modelling resolution of 600m. J. Hydrol. 334(1-2): 73-87.

Vazquez, R.F., L. Feyen, J. Feyen, and J.C. Refsgaard. 2002. Effect of grid size on effective parameters and model performance of the MIKE-SHE code. Hydrol. Process. 16(2): 355-372.

Vrugt, J.A., B.A. Robinson, and J.M. Hyman. 2009. Self-Adaptive Multimethod Search for Global Optimization in Real-Parameter Spaces. Ieee Trans. Evol. Comput. 13(2): 243-259.

Wang, X., X. He, J.R. Williams, R.C. Izaurralde, and J.D. Atwood. 2005. Sensitivity and uncertainty analyses of crop yields and soil organic carbon simulated with EPIC. Trans.-Am. Soc. Agric. Eng. 48(3): 1041.

Wang, X., A. Saleh, M.W. McBroom, J.R. Williams, and L. Yin. 2007. Test of APEX for Nine Forested Watersheds in East Texas. J. Environ. Qual. 36(4): 983-995.

White, K.L., and I. Chaubey. 2005. Sensitivity analysis, calibration, and validation for a multisite and multivariable SWAT model1. Jawra J. Am. Water Resour. Assoc. 41(5): 1077-1089.

Williams, J.R. 1975. Sediment routing for agricultural watersheds. Water Resour. Bull. 11: 965-974.

Williams, J.R., and W.V. LaSeur. 1976. Water yield model using SCS curve numbers. J. Hydraulics Div., ASCE. 102: 1241-1253.

Williams, J.R. 1995. The EPIC model. p. 909-1000. In Computer models in watershed hydrology. V.P. Singh (ed.). Water Resources Publications, Highlands Ranch, CO.

Williams, J.R., J.G. Arnold, R. Srinivasan, and T.S. Ramanarayanan. 1998. APEX: A new tool for predicting the effects of climate and $\mathrm{CO} 2$ changes on erosion and water quality. Model. Soil Eros. Water 1: 441-449.

Williams, J.R., R.C. Izaurralde, and E.M. Steglich. 2008. Agricultural 
policy/environmental extender model: User's manual version 0604. BREC Report \#2008-16. Blackland Research and Extension Center. p. 222. Available at http://epicapex.brc.tamus.edu/downloads/usermanuals.aspx. (verified 12 June 2012).

Yin, L., X. Wang, J. Pan, and P.W. Gassman. 2009. Evaluation of APEX for daily runoff and sediment yield from three plots in the Middle Huaihe River Watershed, China. Trans. ASABE 52(6): 1833-1845.

Zhang, X., R. Srinivasan, K. Zhao, and M.V. Liew. 2009. Evaluation of global optimization algorithms for parameter calibration of a computationally intensive hydrologic model. Hydrol. Process. 23(3): 430-441. 
Table 6.1. Agricultural Policy Environmental Extender (APEX) model equations used for key processes for the watersheds at Greenley Research Center, Missouri.

\begin{tabular}{ll}
\hline Process & Model option used \\
\hline Runoff & Soil moisture index (SMI) based continuous curve number (CN) \\
& method (SCS, 1985; Williams and LaSeur, 1976) \\
Peak runoff rate & The modified rational method (Williams et al., 1998). \\
Potential & The Hargreaves and Samani (1985) method. \\
evaporation & The MUSS equation (small watershed version; (Williams, 1995), a \\
Soil erosion & variant of the Modified Universal Soil Loss Equation (MUSLE; \\
& Williams, 1975) \\
\hline
\end{tabular}


Table 6.2. The Agricultural Environmental Policy and eXtender (APEX) model parameters and their values used for automatic

\begin{tabular}{|c|c|c|}
\hline Sensitive parameter & Calibrated values & Range of values used \\
\hline Parm 17 Soil evaporation - plant cover factor & $0.1^{\S}, 0.3^{\ddagger}, 0.2^{q}$ & $0.18,0.19,0.2,0.21$ \\
\hline Parm 23 Hargreaves PET equation coefficient & & $0.0023,0.0032$ \\
\hline Parm 34 Hargreaves PET equation exponent & $0.5^{\S}, 0.6^{\dagger}, 0.6^{\ddagger}, 0.5^{\natural}$ & $0.5,0.6$ \\
\hline Parm 42 SCS curve number index coefficient & $0.4^{\dagger}, 0.8-1.2^{\ddagger} 1.5^{\S}, 2.5^{\natural}$ & $1,1.5,2,2.5$ \\
\hline Parm 49 Maximum rainfall interception by plant canopy & & $2,3,4,8$ \\
\hline Parm 18 Sediment routing exponent & $1^{\text {॥ }}$ & $1,1.2,1.4,1.5$ \\
\hline Parm 45 Sediment routing travel time coefficient & $7^{\mathbb{1}}$ & $2,4,6,8,10$ \\
\hline Parm 46 RUSLE C-factor coefficient & $1.5^{\S}$ & $0.5,1,1.5$ \\
\hline Parm 47 RUSLE C-factor coefficient & $0.01^{\S}$ & $0.01,0.1,0.4,1,1.5,3$ \\
\hline Parm 19 Sediment routing coefficient, $\left(\mathrm{t} / \mathrm{m}^{3}\right)$ & & $0.005,0.01,0.05$ \\
\hline Parm 29 Biological mixing efficiency & & $0.1,0.2,0.3,0.5$ \\
\hline Parm 69 Coefficient adjusts microbial activity function & $1^{\text {बा }}$ & $0,0.3,0.5,0.7,1$ \\
\hline Parm 31 Maximum depth for biological mixing & $0.2^{\text {Il }}$ & $0.1,0.2,0.3$ \\
\hline Parm 70 Microbial decay rate coefficient & & $0.05,1,1.5$ \\
\hline Parm 8 Soluble phosphorus runoff coefficient & $15^{\pi}$ & $10,12,14,16,18,20$ \\
\hline Parm $59 \mathrm{P}$ upward movement by evaporation coefficient & $12^{\|}$ & $\begin{array}{l}1,3,5,9,11,13,17 \\
19,20\end{array}$ \\
\hline Parm $57 \mathrm{P}$ enrichment ratio coefficient for routing & $0.05^{\dagger}$ & $0.05,0.1,0.15,0.2$ \\
\hline Parm $58 \mathrm{P}$ enrichment ratio exponent for routing & $0.1^{\dagger}$ & $0.2468,0.3,0.4$ \\
\hline Parm $7 \mathrm{~N}$ fixation & & 0,1 \\
\hline Parm 14 Nitrate leaching ratio & & $0.1,0.5,1$ \\
\hline Parm 32 Organic P loss exponent & & $1,1.1,1.2$ \\
\hline Parm 35 Denitrification soil-water threshold & & $0.9,1,1.1$ \\
\hline Parm 72 Volatilization/nitrification partitioning coeff. & & $0.05,0.1,0.2,0.5$ \\
\hline
\end{tabular}

${ }^{\dagger}$ Wang et al. (2007), ${ }^{\ddagger}$ Mudgal et al. (2008), ${ }^{\S}$ Yin et al. (2009), " Senaviratne et al. (2013) 
Table 6.3. Model performance coefficients: Coefficient of determination $\left(r^{2}\right)$ Nash-Sutcliffe Coefficient (NSC), and Percent bias (Pbias) for Agricultural Environmental Policy and eXtender (APEX) model simulation of optimal parameter sets for runoff, sediment, biological activity, total phosphorous (TP), and total nitrogen (TN), selected by different multi-objective functions versus independent observations for the watersheds at Greenley Research Center, Missouri.

\begin{tabular}{|c|c|c|c|c|c|c|c|c|c|c|c|c|c|c|}
\hline \multirow{2}{*}{$\begin{array}{l}\text { Process / } \\
\text { parameter set }\end{array}$} & \multirow{2}{*}{$\begin{array}{l}\text { No. } \\
\text { of } \\
\text { runs }\end{array}$} & \multirow{2}{*}{$\begin{array}{l}\text { Objective } \\
\text { function }\end{array}$} & \multicolumn{2}{|c|}{ Runoff } & \multicolumn{4}{|c|}{ Sediment } & \multicolumn{3}{|c|}{ Total phosphorous } & \multicolumn{3}{|c|}{ Total nitrogen } \\
\hline & & & $\overline{r^{2}}$ & NSC & Pbias & $r^{2}$ & $\mathrm{NSC}$ & Pbias & $r^{2}$ & NSC & Pbias & $r^{2}$ & NSC & Pbias \\
\hline Runoff & 258 & GLUE $^{\dagger}$ & 0.93 & 0.83 & 1.6 & 0.77 & 0.57 & -31.38 & 0.94 & 0.73 & -24.97 & 0.86 & 0.48 & 18.33 \\
\hline $\mathrm{P} 17, \mathrm{P} 23, \mathrm{P} 34$, & & Slope $\mathrm{x} r^{2 *}$ & 0.93 & 0.83 & 3.54 & 0.78 & 0.58 & -30.68 & 0.94 & 0.72 & -24.41 & 0.86 & 0.48 & 18.91 \\
\hline P42, P49 & & $\begin{array}{l}\text { Slope x } r^{2}+ \\
\text { NSC }^{\S}\end{array}$ & 0.93 & 0.83 & 2.57 & 0.77 & 0.58 & -30.88 & 0.94 & 0.73 & -24.62 & 0.86 & 0.48 & 18.98 \\
\hline & & Observed $^{\mathbb{I}}$ & 0.93 & 0.83 & 2.57 & 0.77 & 0.58 & -30.88 & 0.94 & 0.73 & -24.62 & 0.86 & 0.48 & 18.98 \\
\hline Sediment & 1082 & GLUE & 0.93 & 0.82 & 2.89 & 0.78 & 0.54 & -52.95 & 0.93 & 0.82 & -9.76 & 0.86 & 0.45 & 23.97 \\
\hline $\mathrm{P} 18, \mathrm{P} 45$ & & Slope $\mathrm{x} r^{2}$ & 0.93 & 0.82 & 2.61 & 0.78 & 0.20 & -111.58 & 0.93 & 0.20 & -53.66 & 0.84 & 0.55 & 1.59 \\
\hline P46, P47, P19 & & $\begin{array}{l}\text { Slope x } r^{2}+ \\
\text { NSC }\end{array}$ & 0.93 & 0.82 & 2.63 & 0.78 & 0.52 & -60.30 & 0.93 & 0.76 & -18.53 & 0.85 & 0.48 & 17.32 \\
\hline & & Observed & 0.93 & 0.83 & 3.52 & 0.78 & 0.58 & -29.69 & 0.94 & 0.70 & -25.52 & 0.86 & 0.49 & 17.22 \\
\hline Soil biological & 362 & GLUE* & 0.93 & 0.84 & 0.38 & 0.76 & 0.56 & -31.86 & 0.93 & 0.83 & -9.49 & 0.85 & 0.49 & 45.47 \\
\hline activity P29, & & Slope $\mathrm{x} r^{2}$ & 0.93 & 0.81 & 7.10 & 0.80 & 0.61 & -26.69 & 0.94 & 0.40 & -42.69 & 0.87 & 0.50 & 20.65 \\
\hline P69, P31, P70 & & $\begin{array}{l}\text { Slope x } r^{2}+ \\
\text { NSC }\end{array}$ & 0.93 & 0.83 & 3.65 & 0.78 & 0.58 & -30.06 & 0.94 & 0.78 & -17.96 & 0.86 & 0.50 & 18.17 \\
\hline
\end{tabular}

Muiti-objective functions using: ${ }^{\dagger}$ Generalized likelihood uncertainty estimation (GLUE; Eq.6.3), ${ }^{\star}$ mean of slope x coefficient of determination of output variables $\left(r^{2}\right.$; Eq. 6.4), ${ }^{\S}$ means of (slope $\mathrm{x} r^{2}$ ) and NSC of output variables (Eq. 6.5), and ${ }^{\mathrm{q}}$ visual observation 
Table 6.3. Continued.

\begin{tabular}{|c|c|c|c|c|c|c|c|c|c|c|c|c|c|c|}
\hline \multirow{2}{*}{$\begin{array}{l}\text { Process / } \\
\text { parameter set }\end{array}$} & \multirow{2}{*}{$\begin{array}{l}\text { No. } \\
\text { of } \\
\text { runs }\end{array}$} & \multirow{2}{*}{$\begin{array}{l}\text { Objective } \\
\text { function }\end{array}$} & \multicolumn{2}{|c|}{ Runoff } & \multicolumn{4}{|c|}{ Sediment } & \multicolumn{3}{|c|}{ Total phosphorous } & \multicolumn{3}{|c|}{ Total nitrogen } \\
\hline & & & $r^{2}$ & NSC & Pbias & $r^{2}$ & NSC & Pbias & $r^{2}$ & NSC & Pbias & $r^{2}$ & NSC & Pbias \\
\hline \multirow{4}{*}{$\begin{array}{l}\text { TP } \\
\text { P8, P59, P57, } \\
\text { P58 }\end{array}$} & \multirow{4}{*}{650} & Observed & 0.93 & 0.84 & 0.38 & 0.76 & 0.56 & -31.63 & 0.93 & 0.83 & -9.49 & 0.85 & 0.50 & 14.36 \\
\hline & & GLUE & 0.93 & 0.82 & 2.68 & 0.78 & 0.58 & -29.3 & 0.94 & 0.87 & 5.52 & 0.86 & 0.49 & 18.21 \\
\hline & & Slope $\mathrm{x} r^{2}$ & 0.93 & 0.83 & 2.69 & 0.78 & 0.58 & -29.3 & 0.94 & 0.62 & -32.44 & 0.86 & 0.49 & 18.23 \\
\hline & & $\begin{array}{l}\text { Slope } \mathrm{x} r^{2}+ \\
\text { NSC }\end{array}$ & 0.93 & 0.83 & 2.68 & 0.78 & 0.58 & -29.28 & 0.94 & 0.81 & -13.38 & 0.86 & 0.49 & 18.23 \\
\hline \multirow{5}{*}{$\begin{array}{l}\text { TN } \\
\text { P7, P14, P32, } \\
\text { P35, P72 }\end{array}$} & \multirow{5}{*}{218} & Observed & 0.93 & 0.82 & 2.68 & 0.78 & 0.58 & -29.3 & 0.94 & 0.87 & 5.52 & 0.86 & 0.49 & 18.21 \\
\hline & & GLUE & 0.93 & 0.83 & 1.29 & 0.77 & 0.58 & -29.3 & 0.94 & 0.87 & 0.95 & 0.86 & 0.50 & 15.49 \\
\hline & & Slope $\mathrm{x} r^{2}$ & 0.93 & 0.83 & 1.57 & 0.78 & 0.58 & -28.91 & 0.94 & 0.79 & -14.12 & 0.86 & 0.49 & 17.17 \\
\hline & & $\begin{array}{l}\text { Slope } \mathrm{x} r^{2}+ \\
\text { NSC }\end{array}$ & 0.93 & 0.83 & 1.57 & 0.78 & 0.58 & -28.91 & 0.94 & 0.84 & -6.26 & 0.86 & 0.49 & 17.17 \\
\hline & & Observed & 0.93 & 0.83 & 1.29 & 0.77 & 0.58 & -29.1 & 0.94 & 0.87 & 0.95 & 0.86 & 0.50 & 15.49 \\
\hline
\end{tabular}


Table 6.4. The optimum parameter sets of runoff, sediment, biological activity, total phosphorous (TP), and total nitrogen (TN) selected by different multi-objective functions and independent observations during calibration of the Agricultural Environmental Policy and eXtender (APEX) model for the watersheds at the Greenley Research Center, Missouri.

\begin{tabular}{|c|c|c|c|c|}
\hline $\begin{array}{l}\text { Process / output variable, } \\
\text { their parameters and } \\
\text { values used }\end{array}$ & $\begin{array}{l}\text { Muiti-objective } \\
\text { functions using: } \\
* \text { Generalized } \\
\text { likelihood } \\
\text { uncertainty } \\
\text { estimation } \\
\text { (GLUE; Eq.6.3) }\end{array}$ & $\begin{array}{l}\text { Mean of slope } \\
\mathrm{x} \text { coefficient } \\
\text { of } \\
\text { determination } \\
\text { of output } \\
\text { variables }\left(r^{2} ;\right. \\
\text { Eq. 6.4) }\end{array}$ & $\begin{array}{l}\text { Means of } \\
\left(\text { slope } \mathrm{x} r^{2} \text { ) }\right. \\
\text { and NSC of } \\
\text { output } \\
\text { variables } \\
\text { (Eq. 6.5), }\end{array}$ & $\begin{array}{l}\text { Independent } \\
\text { observation }\end{array}$ \\
\hline \multicolumn{5}{|l|}{ Runoff } \\
\hline $17(0.18,0.19,0.2,0.21)$ & 0.2 & 0.2 & 0.2 & 0.2 \\
\hline $23(0.0023,0.0032)$ & 0.0023 & 0.0023 & 0.0023 & 0.0023 \\
\hline $34(0.5,0.6)$ & 0.5 & 0.5 & 0.5 & 0.5 \\
\hline $42(1,1.5,2,2.5)$ & 2.5 & 2.5 & 2.5 & 2.5 \\
\hline $49(2,3,4,8)$ & 2 & 4 & 3 & 3 \\
\hline \multicolumn{5}{|l|}{ Sediment } \\
\hline $18(1,1.2,1.4,1.5)$ & 1.5 & 1.4 & 1.5 & 1.5 \\
\hline $45(2,4,6,8,10)$ & 10 & 4 & $6 / 8$ & 8 \\
\hline $46(0.5,1,1.5)$ & 0.5 & 0.5 & $0.5 / 1$ & 1.5 \\
\hline $47(0.01,0.1,0.4,1,1.5,3)$ & 3 & 0.01 & 0.01 & 0.01 \\
\hline $19(0.005,0.01,0.05)$ & $0.005 / 0.01 / 0.05$ & $0.005 / 0.01 / 0.05$ & $0.005 / 0.01 / 0.0$ & 050.01 \\
\hline \multicolumn{5}{|l|}{ Soil biological activity } \\
\hline $29(0.1,0.2,0.3,0.5)$ & 0.5 & 0.1 & 0.3 & 0.5 \\
\hline $69(0,0.3,0.5,0.7,1)$ & 1 & 1 & 1 & 1 \\
\hline $31(0.1,0.2,0.3)$ & 0.3 & 0.1 & 0.3 & 0.1 \\
\hline $70(0.05,1,1.5)$ & 1.5 & 1.5 & 1.5 & 1.5 \\
\hline \multicolumn{5}{|l|}{$\mathrm{TP}$} \\
\hline $8(10,12,14,16,18,20)$ & 20 & 10 & 20 & 20 \\
\hline $59(1,3,5,9,11,13,17,19$ & 1 & 20 & 13 & 1 \\
\hline 20) & $0.05 / 0.1 / 0.15 / 0$ & $20.05 / 0.1 / 0.15 /$ & /0.05/ 0.1/0.15/ & 0.1 \\
\hline $57(0.05,0.1,0.15,0.2)$ & $0.2468 / 0.3 / 0.4$ & 0.2 & 0.2 & \\
\hline $58(0.2468,0.3,0.4)$ & & $\begin{array}{l}0.2468 / \\
0.3 / 0.4\end{array}$ & $0.2468 / 0.3 / 0.4$ & 0.3 \\
\hline \multicolumn{5}{|l|}{$\mathrm{TN}$} \\
\hline $7(0,1)$ & 0 & 0 & 0 & 0 \\
\hline $14(0.1,0.5,1)$ & 1 & 1 & 1 & 1 \\
\hline $32(1,1.1,1.2)$ & 1 & 1.2 & 1.1 & 1.2 \\
\hline $35(0.9,1,1.1)$ & $0.9 / 1 / 1.1$ & $0.9 / 1 / 1.1$ & $0.9 / 1 / 1.1$ & 1.1 \\
\hline $72(0.05,0.1,0.2,0.5)$ & 0.1 & 0.1 & 0.05 & 0.05 \\
\hline
\end{tabular}


Table 6.5. Agricultural Policy Environmental Extender model (APEX) performances for coefficient of determination $\left(r^{2}\right)$, Nash-Sutcliffe coefficient (NSC), and percent bias (Pbias) values for event-based runoff, sediment, total phosphorus (TP), and total nnitrogen $(\mathrm{TN})$ predictions for Center, West, and East watersheds at Greenley Research Center, Missouri, for calibration and validation of manual versus automatic parameter optimization methods.

\begin{tabular}{|c|c|c|c|c|c|c|c|}
\hline \multirow{3}{*}{$\begin{array}{l}\text { Model } \\
\text { output }\end{array}$} & \multirow{3}{*}{$\begin{array}{l}\text { Model } \\
\text { performance }\end{array}$} & \multirow{2}{*}{\multicolumn{2}{|c|}{$\begin{array}{c}\text { Calibration } \\
\text { Center }\end{array}$}} & \multicolumn{4}{|c|}{ Validation } \\
\hline & & & & \multicolumn{2}{|c|}{ West } & \multicolumn{2}{|r|}{ East } \\
\hline & & Manual $\uparrow$ & Automatic & Manual & Automatic & Manual & Automatic \\
\hline \multirow[t]{3}{*}{ Runoff } & $r^{2}$ & 0.94 & 0.93 & 0.91 & 0.96 & 0.93 & 0.98 \\
\hline & $\mathrm{NSC}$ & 0.84 & 0.83 & 0.80 & 0.85 & 0.87 & 0.96 \\
\hline & Pbias & 3.66 & 1.29 & 25.78 & 21.32 & 19.24 & -4.55 \\
\hline \multirow[t]{3}{*}{ Sediment } & $r^{2}$ & 0.59 & 0.77 & 0.34 & 0.98 & 0.35 & 0.65 \\
\hline & NSC & 0.56 & 0.58 & 0.26 & 0.93 & 0.19 & 0.21 \\
\hline & Pbias & -26.82 & -29.1 & -52.12 & -12.16 & -67.63 & -83.76 \\
\hline \multirow[t]{3}{*}{ TP } & $r^{2}$ & 0.87 & 0.94 & 0.80 & 0.90 & 0.78 & 0.89 \\
\hline & NSC & 0.67 & 0.80 & 0.78 & 0.80 & 0.32 & 0.76 \\
\hline & Pbias & 32.8 & 0.95 & -7.18 & 8.96 & -51.15 & -13.47 \\
\hline \multirow[t]{3}{*}{$\mathrm{TN}$} & $r^{2}$ & 0.74 & 0.86 & 0.53 & 0.76 & 0.57 & 0.72 \\
\hline & NSC & 0.44 & 0.50 & 0.31 & 0.35 & 0.18 & 0.24 \\
\hline & Pbias & 17.88 & 15.49 & 24.56 & 23.79 & 46.58 & 43.97 \\
\hline
\end{tabular}

$\uparrow$ Manual sensitivity analysis and calibration values from Senaviratne et al. (2013) 


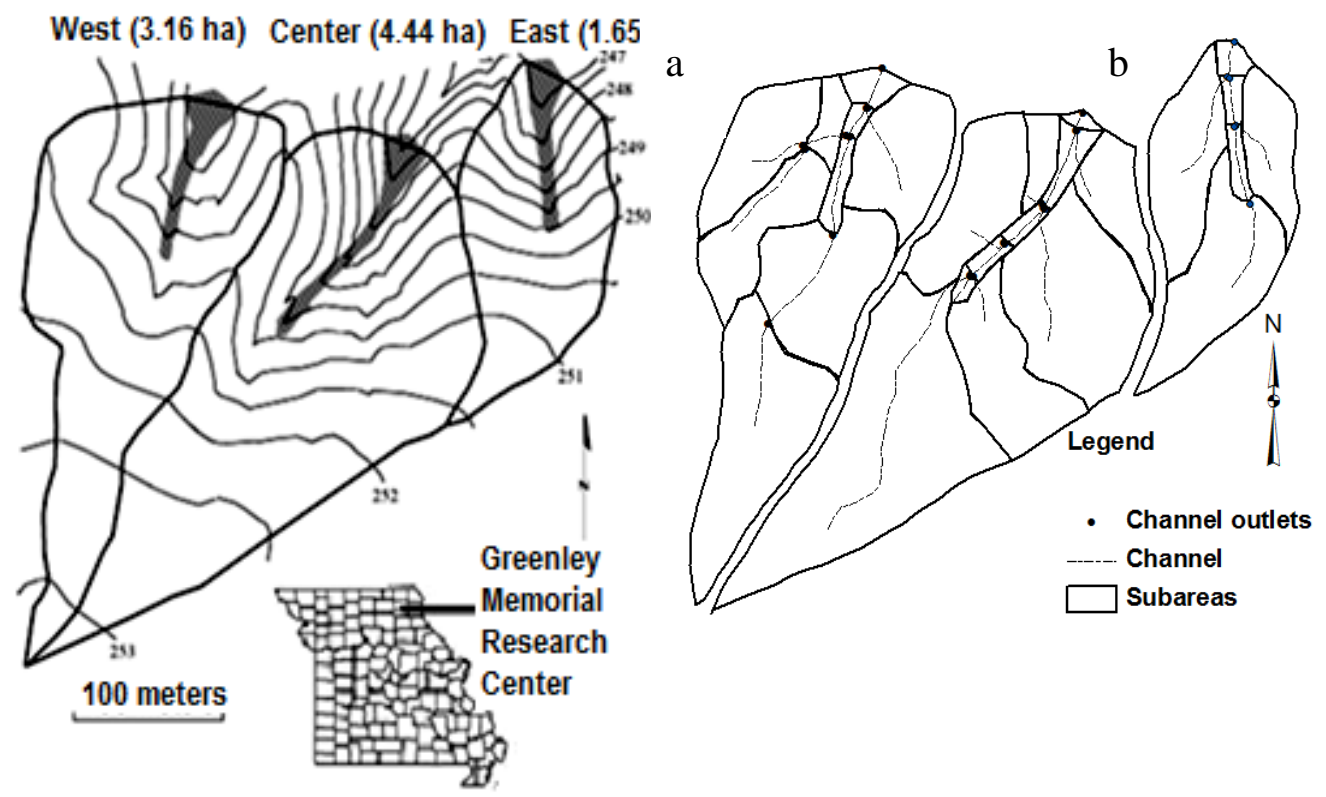

Fig. 6.1. Topographic map (0.5-m interval) of the West, Center, and East watersheds (adapted from Udawatta et al., 2002; a). Grey lines represent contour lines (thin) and grass waterways (wide). The inset map shows the approximate location of the study site in Knox County, Missouri. ArcAPEX model delineated subareas and stream network of the three watersheds (adapted from Senaviratne et al., 2013; b). 


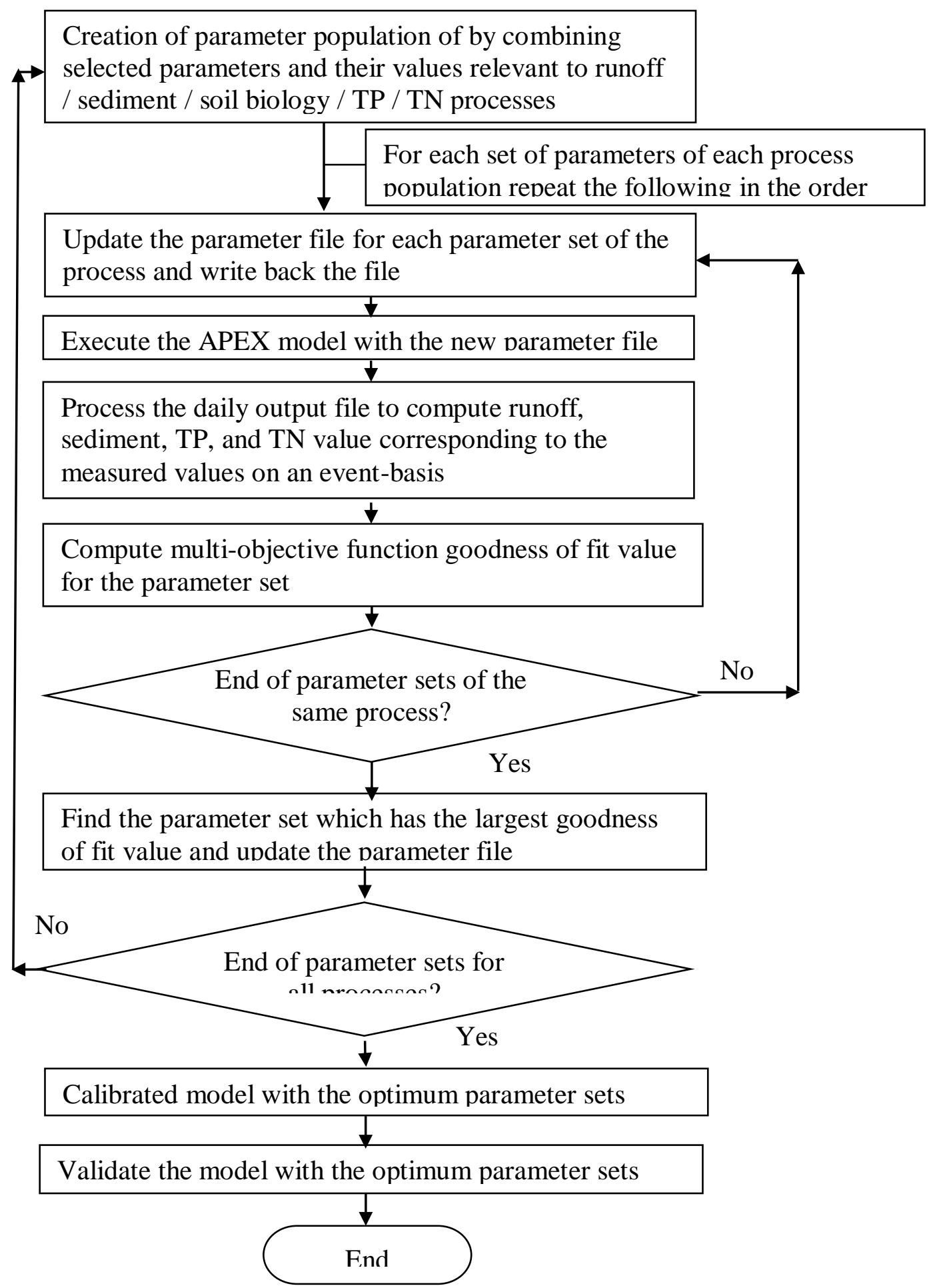

Fig. 6.2. Program flow of the module for the multi-objective, multi-variable parameter optimization and calibration of Agricultural Environmental Policy and eXtender (APEX) model for the watersheds at Greenley Research Center, Missouri. 

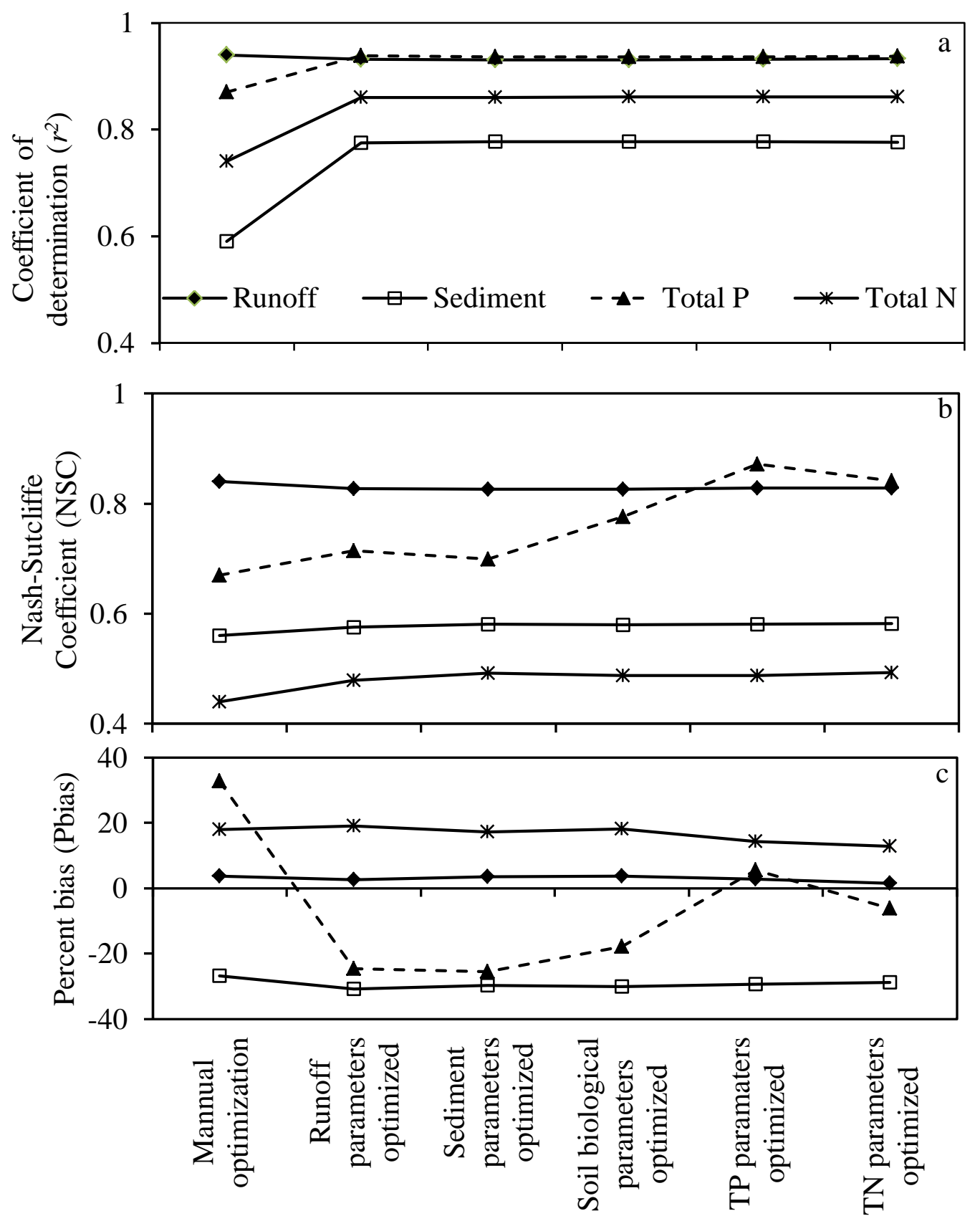

Fig. 6.3. Progress of the model performance coefficients of Coefficient of determination $\left(r^{2} ; \mathrm{a}\right)$, Nash-Sutcliffe Coefficient (NSC; b), and Percent bias (Pbias; c) during stepwise parameter optimization and calibration process of the Agricultural Environmental Policy and eXtender (APEX) model. 


\section{CONCLUSIONS}

Four studies were conducted to evaluate the environmental benefits of agroforestry buffers with hydrologic models. The permanent upland contour buffers consisted of trees and grass, in corn-soybean field-size watersheds in the claypan region. All the studies were based on a unique long-term paired watershed study conducted for 17 years starting from 1991 with three adjacent small watersheds at the Greenley Memorial Research Center of University of Missouri, Knox County, Missouri. The rowcrop watersheds with grass waterways were monitored from 1991 to 1997 for a calibration period. In 1997, the two treatments: contour upland grass buffers and agroforestry (tree+grass) buffers were randomly assigned to West and Center watersheds while the East watershed was maintained as the Control. Event based data of runoff, sediment, total phosphorous (TP), and total nitrogen (TN) of the three watersheds of both pre- and post-buffer periods were used for the calibration and validation of the models and scenario analyses. Four studies were conducted for this project. Studies one, two, and four evaluated the use of the physically-based, distributed, hydrologic, Agricultural Policy Environmental eXtender (APEX) model and study three evaluated the use of a fuzzy logic (FL) with genetic algorithm (GA) optimization model for prediction of runoff based on rainfall as an alternative tool for watershed assessment in the absence of physical data. The following conclusions were developed from the four studies conducted for this project. 


\section{Study 1: APEX simulation of three adjacent row-crop watersheds in the claypan region}

The watershed data from the pre-buffer period was used for this study. A manual sensitivity analysis was performed on simulated runoff, sediment, dissolved nitrogen (DN), TN, dissolved phosphorous (DP), TP, and crop yields for the Center watershed to identify the most sensitive model parameters for the APEX model. All the simulated model outputs were found to be sensitive to the Hargreaves PET equation exponent (P[34]) parameter. Runoff and corn yield predictions were sensitive to SCS curve number index coefficient (P[42]). Sediment, TN, and TP were sensitive to average upland slope (CHSO) and sediment routing exponent (P[18]). The sensitive parameters listed in this study could be useful for parameterization of the APEX model in the claypan region. The APEX model was parameterized, calibrated, and validated for crop yields, event-based runoff, sediment, TN and TP for three pre-buffer watersheds with grass waterways. The model simulated crop yields were within $\pm 13 \%$ of the measured yields. The model was well calibrated and validated for event-based runoff with $r^{2}$ and NSC between 0.8-0.9. The model was calibrated for sediment and TN for larger rainfall events ( $>50-\mathrm{mm}$ ) with $r^{2}>0.5$ and NSC $>0.4$ but model performance indicators for validation were poor. Total $\mathrm{P}$ was better calibrated and validated than sediment and TN, with $r^{2}$ and NSC values between 0.7 and 0.8 for larger rainfall events (> 50-mm). The study also emphasizes the importance of accurate sediment measurements during small and medium runoff events to avoid underestimation of sediment loads due to the flume bed deposition. Long-term simulations of watersheds predicted $13-25 \%$ reduction in 
annual TP losses due the presence of grass waterways compared to none confirming the importance of grass waterways in reducing pollutant loadings. These findings also indicate the importance of grass waterways for enhanced environmental benefits. The APEX model provided an efficient tool to simulate the best management practices evaluate their impact on NPSP reductions.

\section{Study 2: APEX simulation: environmental benefits of agroforestry and grass buffers on corn-soybean watersheds}

The APEX model was reasonably calibrated and validated for crop yield, eventbased runoff and event-based TP loadings of the long-term monitored study watersheds located at the Greenley Memorial Research Center, in Northeast Missouri, with upland contour agroforestry and grass buffers, and the control treatment. The $r^{2}$ and NSC values were between $0.5-0.8$ for runoff and TP for calibration and they were over 0.4 for validation. The model could not be calibrated for sediments and total nitrogen probably due to low concentrations as a result of buffers as well as less intensity rainfall events during the study period. Underestimation of larger particles in the measured samples due to sedimentation on flume beds prior to the sampling point may also have affected sediment calibration results. The long-term scenario analysis of a buffer width increase from 4.5 to $5.5 \mathrm{~m}$ and $7.5 \mathrm{~m}$ showed no significant reduction in TP loads. The long-term scenario analysis showed 4 to $5 \%$ reductions in average annual runoff and 13 to $45 \%$ reduction in average annual TP loadings due to the presence of buffers. The greater reductions in both annual runoff and TP loadings were observed for the CGS buffer 
watershed. The buffers in backslope positions were for reducing runoff and TP loads in the agroforestry watershed. Winter cover crops contributed a reduction of $15-24 \%$ in annual TP losses. The results of this unique study demonstrated that APEX may be used to evaluate environmental benefits of upland buffers and winter cover crops, provided sufficient long-term data are available for calibration and validation.

\section{Study 3: Performance of Geno-Fuzzy Model on Rainfall-Runoff Predictions in Claypan Watersheds}

The fuzzy inference system (FIS) with the GA optimization predicted event-based runoff with the model performance coefficients of $r^{2}$ and NSC values between 0.68 and 0.84 for both the pre- and post-buffer corn-soybean watersheds with intermittent stream discharge and claypan soils during calibration and validation. Fewer than four MFs produced poor model performances. The GA optimization of the $\mathrm{x}$-coordinates of MFs moderately improved model performance of the FIS for both pre- and post-buffer periods. The creation of the initial membership functions for rainfall and runoff was the primary factor for the successful model performance in this study The presence of historical data representing a wide range of storm intensities are important for such definitions. The FIS predictions for post-buffer watersheds showed 15 to $16 \%$ reductions in the event-based runoff compared to the pre-buffer period. This was comparable with 15 to $23 \%$ reductions in measured runoff due to the presence of AGF and CGS buffers. The FIS predictions for event-based runoff for the three watersheds were very close to the prediction made by the physically-based APEX model for both pre- and post-buffer 
watersheds. Once calibrated for the small watersheds, the FIS predicted event-based runoff for 30 and 50 times larger watersheds with $r^{2}$ and NSC values between 0.53 and 0.82. The FIS calibrated for the AGF and CGS buffer watersheds predicted 8 to $15 \%$ reductions in runoff on larger watersheds if agroforestry or grass buffers were established. The presence of long-term data for small and intermittent stream discharges and with different management practices of agroforestry and grass buffers make this study uniquely quantifying the application of FIS. The FIS could be used as an efficient tool for estimating event-based runoff in the absence of detailed watershed data.

\section{Study 4: Multi-variable, multi-objective stepwise parameter optimization for Agricultural Environmental Policy eXtender model}

An output variable based, stepwise, multi-variable and multi-objective function parameter optimization and automatic calibration of the APEX model was carried out for three adjacent pre-buffer watersheds for event-based runoff, sediment, TN, and TP. The parameter sets for each group of stepwise optimization were: runoff, sediment, soil biological activity, TP, and TN, and their spaces were selected based on previous findings of a manual sensitivity analysis and the user manual. The optimization of the model was carried out with groups of parameters in the order of runoff, sediment, soil biological activities, TP and TN. Several objective functions were evaluated for the selection of optimal parameter sets. The objective function based on GLUE method selected the optimum parameter set or close to it for all output variables except for the sediment for which the objective function based on $r^{2}$, slope and NSC gave the best selection. The 
model performance for runoff was not affected by any of the parameter optimization techniques compared with the baseline values. However, optimization for runoff parameters produced significant improvements in sediment predictions with a $31 \%$ increase in $r^{2}$ values compared to the manual baseline values. The $r^{2}$ values of TP and TN also improved by $7 \%$ and 14\%, respectively. The NSC values were also increased by $3 \%, 7 \%$ and $9 \%$ for sediment, $\mathrm{TP}$ and $\mathrm{TN}$, respectively after parameter optimization for runoff. The only other improvements were observed for NSC and Pbias values for TP. The NSC values were increased by $15 \%$ and $25 \%$ by the optimization of biological and $\mathrm{P}$ parameters, respectively. The Pbias values for TP showed large fluctuations and were reduced to $6 \%$ from $32 \%$ after biological and $\mathrm{P}$ parameter optimization. The validation of the calibrated model for West and East watersheds showed considerable improvements in model performances. The largest improvements were observed for the East watershed for runoff and the West watershed for sediment. The study concludes that runoff parameter optimization was the key for the subsequent improvements in simulations of sediment, TP, and TN. Manual sensitivity analysis was helpful to screen out sensitive parameters and determine their sensitive spaces to reduce the number of runs needed for the automatic calibration. A reduced number of parameters and limited set of values coupled with stepwise optimization offered a less computer intensive, affordable, and effective global optimization method for model calibration of the APEX model. The current study only considered the parameters listed in the parameter file of the APEX model. Hence, future research on parameter optimization may consider other parameters listed in subarea, soil, operations, and control input files. 


\section{Summary}

In summary this project using long-term-data available from this unique study with three adjacent watersheds indicates that the APEX model with sufficient parameter optimization could be used to evaluate and quantify the benefits of conservation practices such as grass waterways, agroforestry buffers on reduction of non-point source pollutions and improving water quality. The results of the stepwise multi-variable, multi-objective parameter optimization of the model highlighted the importance of runoff parameter optimization in order for the model to simulate sediment, TP, and TN losses more accurately. Moreover with the developed stepwise multi-variable, multi-objective parameter optimization technique using the GLUE technique could be used to reduce the uncertainty in the predictions of any hydrologic model thus making them more reliable in predictions of environmental benefits of simulated conservation practices. The fuzzy logic model predicted runoff with reasonable accuracy not only for calibration and validation but also for relatively larger watersheds using the rainfall data. It offers an alternative tool for runoff prediction in the case of absence of detailed physical data or detailed modeling is not required. 


\section{APENDIX}


A 1. Annual measured runoff of the Center / agroforestry buffer, West / Contour grass, and East / Control watershed during pre- and post-buffer periods at Greenley Memorial Research Center, Missouri. U.S.A.

\begin{tabular}{|c|c|c|c|c|}
\hline & \multirow[t]{4}{*}{ Year } & \multicolumn{3}{|c|}{ Annual measured runoff $(\mathrm{mm})$} \\
\hline & & \multirow{3}{*}{$\begin{array}{c}\text { Center / } \\
\text { Agroforestry } \\
\text { watershed }\end{array}$} & \multirow{3}{*}{$\begin{array}{c}\text { West/ Contour } \\
\text { grass } \\
\text { watershed }\end{array}$} & \multirow{3}{*}{$\begin{array}{c}\text { East / Control } \\
\text { watershed }\end{array}$} \\
\hline & & & & \\
\hline & & & & \\
\hline Pre-buffer & 1991 & 27.38 & 38.46 & 73.66 \\
\hline \multirow[t]{6}{*}{ period } & 1992 & 91.64 & 157.63 & 301.88 \\
\hline & 1993 & 227.86 & 252.18 & 263.94 \\
\hline & 1994 & 17.46 & 27.82 & 25.83 \\
\hline & 1995 & 217.28 & 260.64 & 263.84 \\
\hline & 1996 & 212.66 & 206.97 & 209.59 \\
\hline & 1997 & 127.44 & 118.74 & 129.75 \\
\hline Post-buffer & 1998 & 189.88 & 253.29 & 250.86 \\
\hline \multirow[t]{10}{*}{ period } & 1999 & 87.94 & 88.63 & 131.71 \\
\hline & 2000 & NA & NA & NA \\
\hline & 2001 & NA & NA & NA \\
\hline & 2002 & 35.74 & 41.96 & 43.33 \\
\hline & 2003 & 41.23 & 52.52 & 63.89 \\
\hline & 2004 & 46.24 & 60.70 & 74.24 \\
\hline & 2005 & 22.00 & 28.45 & 32.24 \\
\hline & 2006 & NA & NA & NA \\
\hline & 2007 & 4.84 & 7.28 & 7.39 \\
\hline & 2008 & 37.84 & 48.42 & 52.12 \\
\hline
\end{tabular}


A 2. Annual measured sediment load of the Center / agroforestry buffer, West / Contour grass, and East / Control watershed during pre- and post-buffer periods at Greenley Memorial Research Center, Missouri. U.S.A.

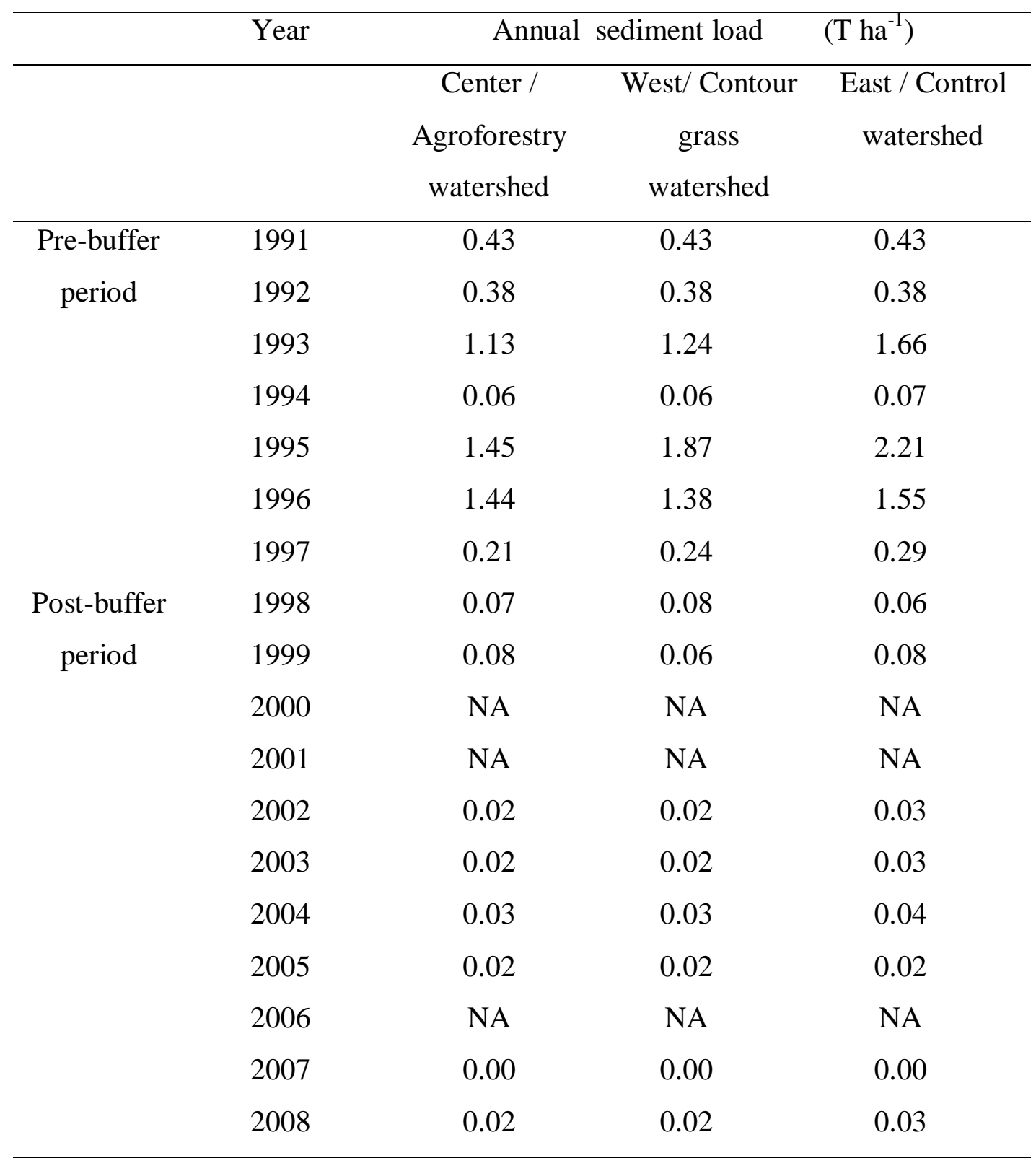


A 3. Measured annual total phosphorous load of the Center / agroforestry buffer, West / Contour grass, and East / Control watershed during pre- and post buffer periods at Greenley Memorial Research Center, Missouri. U.S.A.

\begin{tabular}{|c|c|c|c|c|}
\hline & \multirow[t]{4}{*}{ Year } & \multicolumn{3}{|c|}{ Annual Total phosphorous $\left(\mathrm{kg} \mathrm{ha}^{-1}\right)$} \\
\hline & & \multirow{3}{*}{$\begin{array}{c}\text { Center / } \\
\text { Agroforestry } \\
\text { watershed }\end{array}$} & \multirow{3}{*}{$\begin{array}{c}\text { West/ Contour } \\
\text { grass } \\
\text { watershed }\end{array}$} & \multirow{3}{*}{$\begin{array}{c}\text { East / Control } \\
\text { watershed }\end{array}$} \\
\hline & & & & \\
\hline & & & & \\
\hline Pre-buffer & 1991 & 0.43 & 0.43 & 0.43 \\
\hline \multirow[t]{6}{*}{ period } & 1992 & 11.97 & 23.26 & 23.26 \\
\hline & 1993 & 1.27 & 1.51 & 1.43 \\
\hline & 1994 & 0.08 & 0.08 & 0.25 \\
\hline & 1995 & 1.53 & 2.08 & 70.49 \\
\hline & 1996 & 1.52 & 1.49 & 1.41 \\
\hline & 1997 & 0.31 & 0.31 & 0.23 \\
\hline Post-buffer & 1998 & 0.94 & 1.57 & 0.81 \\
\hline \multirow[t]{10}{*}{ period } & 1999 & 0.38 & 0.46 & 0.13 \\
\hline & 2000 & NA & NA & NA \\
\hline & 2001 & NA & NA & NA \\
\hline & 2002 & 0.17 & 0.21 & 0.11 \\
\hline & 2003 & 0.00 & 0.00 & 0.00 \\
\hline & 2004 & 0.13 & 0.17 & 0.13 \\
\hline & 2005 & 0.00 & 0.00 & 0.00 \\
\hline & 2006 & NA & NA & NA \\
\hline & 2007 & 0.00 & 0.00 & 0.00 \\
\hline & 2008 & 0.00 & 0.43 & 0.00 \\
\hline
\end{tabular}


A 4. Measured annual total nitrogen load of the Center / agroforestry buffer, West / Contour grass, and East / Control watershed during pre- and post buffer periods at Greenley Memorial Research Center, Missouri. U.S.A.

\begin{tabular}{|c|c|c|c|c|}
\hline & \multirow[t]{2}{*}{ Year } & \multicolumn{3}{|c|}{ Annual total nitrogen $\left(\mathrm{kg} \mathrm{ha}^{-1}\right)$} \\
\hline & & $\begin{array}{c}\text { Center / } \\
\text { Agroforestry } \\
\text { watershed }\end{array}$ & $\begin{array}{c}\text { West/ Contour } \\
\text { grass } \\
\text { watershed }\end{array}$ & $\begin{array}{l}\text { East / Control } \\
\text { watershed }\end{array}$ \\
\hline Pre-buffer & 1991 & 2.99 & 2.99 & 2.99 \\
\hline \multirow[t]{6}{*}{ period } & 1992 & 2.45 & 2.45 & 2.54 \\
\hline & 1993 & 25.91 & 22.64 & 24.31 \\
\hline & 1994 & 0.58 & 1.46 & 1.09 \\
\hline & 1995 & 10.00 & 17.50 & 14.90 \\
\hline & 1996 & 13.89 & 13.78 & 12.87 \\
\hline & 1997 & 4.67 & 4.73 & 3.31 \\
\hline Post-buffer & 1998 & 6.56 & 5.51 & 6.32 \\
\hline \multirow[t]{10}{*}{ period } & 1999 & 1.02 & 1.08 & 1.78 \\
\hline & 2000 & NA & NA & NA \\
\hline & 2001 & NA & NA & NA \\
\hline & 2002 & 4.21 & 4.59 & 6.35 \\
\hline & 2003 & 2.85 & 3.12 & 4.40 \\
\hline & 2004 & 13.17 & 15.89 & 22.85 \\
\hline & 2005 & 0.55 & 0.69 & 0.91 \\
\hline & 2006 & NA & NA & NA \\
\hline & 2007 & 0.00 & 0.00 & 0.00 \\
\hline & 2008 & 0.00 & 0.00 & 0.00 \\
\hline
\end{tabular}




\section{VITA}

Anomaa Senaviratne received her bachelor's degree in Agriculture from the University of Peradeniya, Sri Lanka and proceeded to obtain a Master's degree in Agriculture (Soil Science) from the Post Graduate Institute of Agriculture, University of Peradeniya, Sri Lanka. After working as a Research and training officer in the field of agriculture for a while she obtained a Post-Graduate Diploma in Computer Technology from the University of Colombo, Sri Lanka. Thereafter she worked in various capacities such as a curriculum developer, lecturer, and coordinator at computer technology institutions catering for information technology. In 2003 she completed the Master's degree in Computer science from the Post Graduate Institute of Science, University of Peradeniya. She joined the Medical Faculty of University of Peradeniya as an Assistant Lecture to work on medical informatics and continued to work in the same capacity after graduation. In May 2013 she received the Doctorate degree in Soil Science from the University of Missouri under the supervision of Dr. Ranjith P. Udawatta and Dr. Stephen H. Anderson. She also obtained the Certificate in Geographic Information Systems. After graduation she has accepted a post-doctoral position at the University of Missouri and she will be working with Dr.Claire Baffaut and Dr. Ranjith Udawatta. 